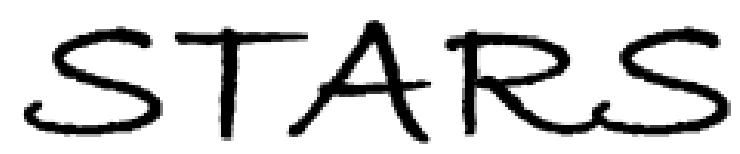

University of Central Florida

STARS

\title{
Application of Landfill Treatment Approaches for the Stabilization of Municipal Solid Waste
}

Stephanie Bolyard

University of Central Florida

Part of the Environmental Engineering Commons

Find similar works at: https://stars.library.ucf.edu/etd

University of Central Florida Libraries http://library.ucf.edu

This Doctoral Dissertation (Open Access) is brought to you for free and open access by STARS. It has been accepted for inclusion in Electronic Theses and Dissertations, 2004-2019 by an authorized administrator of STARS. For more information, please contact STARS@ucf.edu.

\section{STARS Citation}

Bolyard, Stephanie, "Application of Landfill Treatment Approaches for the Stabilization of Municipal Solid Waste" (2016). Electronic Theses and Dissertations, 2004-2019. 4878.

https://stars.library.ucf.edu/etd/4878

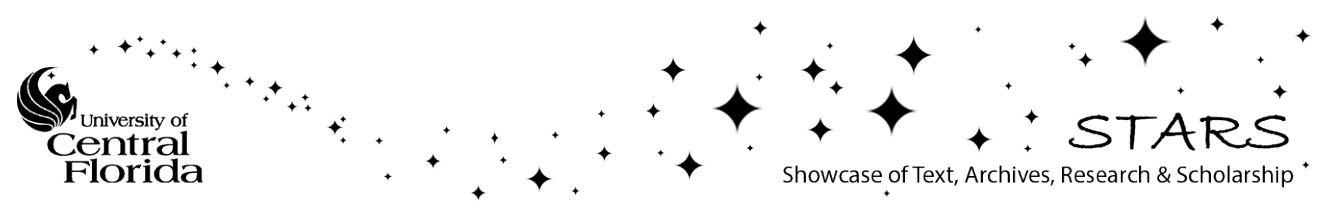




\title{
APPLICATION OF LANDFILL TREATMENT APPROACHES FOR THE STABILIZATION OF MUNICIPAL SOLID WASTE
}

\author{
by
}

STEPHANIE C. BOLYARD

B.S. University of Florida, 2008

M.S. University of Central Florida, 2012

A dissertation submitted in partial fulfillment of the requirements

for the degree of Doctor of Philosophy

in the Department of Civil, Environmental, and Construction Engineering in the College of Engineering and Computer Science at the University of Central Florida Orlando, Florida

Spring Term

2016

Major Professor: Debra R. Reinhart 
(C) 2016 Stephanie C. Bolyard 


\begin{abstract}
This research focused on the fundamental requirements of stabilizing a mature landfill using three treatment approaches as well as the implications of discharging leachate organic matter (LOM) to wastewater treatment plants (WWTPs). Three treatment approaches aimed at removing releasable carbon and nitrogen from mature landfills including flushing with clean water, leachate recirculation with ex-situ chemical oxidation, and leachate recirculation with exsitu chemical oxidation and in-situ aeration were evaluated. After extensive treatment of the waste in the flushing bioreactor (FB) scenarios, the overall biodegradable fraction was reduced relative to mature waste. Leachate quality improved for all FBs but through different mechanisms. Flushing was the most effective approach at removing biodegradable components and improving leachate quality. A mass balance on carbon and nitrogen revealed that a significant fraction still remained in the waste.

Solid waste and leachate samples from the anaerobic bioreactors and FBs were characterized using Fourier Transform Infrared (FTIR) to provide a better understanding of changes in waste characteristics when waste transitions from mature to stabilized. Organic functional groups associated with aliphatic methylene were present in leachate and solid waste samples during the early stages of anaerobic degradation and disappeared once these wastes underwent treatment. Once the waste was stabilized, the FTIR spectra of leachate and solid waste were dominated by inorganic functional groups (carboxylic acid/carbonate group, carbonate, quartz, and clay minerals).

Leachate is commonly co-treated with domestic wastewater due to the cost and complexity of on-site treatment. The organic constituents in leachate can be problematic for
\end{abstract}


WWTPs as their recalcitrant components pass through conventional treatment processes, impacting effluent quality. Twelve leachates where characterized for total nitrogen (TN) and dissolved organic nitrogen (DON). The average concentration of TN and DON in leachate was 1,160 and $40.7 \mathrm{mg} / \mathrm{L}$, respectively. Leachates were fractionated based on hydrophobic (recalcitrant; rDON) and hydrophilic (bioavailable; bDON) properties. The average concentrations of bDON and $\mathrm{rDON}$ were 16.5 and $18.4 \mathrm{mg} / \mathrm{L}$, respectively. Multiple leachate and wastewater co-treatment simulations were carried out to assess the treatment of leachate nitrogen at historic nitrogen removal levels of four WWTPs and the effects on wastewater effluent quality for four WWTPs. The effluent quality exceeded typical TN limits of 3 to 10 $\mathrm{mg} / \mathrm{L}$ at leachate volumetric contributions of $10 \%$. The maximum calculated pass through concentrations of rDON and DON at $10 \%$ volumetric contribution for the twelve leachates was 4.77 and $9.71 \mathrm{mg} / \mathrm{L}$, respectively.

The effects of LOM on wastewater effluent quality was further evaluated in the field. Results showed that leachate detection for each field study could be determined using $\mathrm{UV}_{254 \mathrm{~nm}}$ absorbance. DON and dissolved organic carbon (DOC) concentrations increased at significant levels in leachate-impacted wastewater samples. The DON decreased through the treatment train, suggesting that this parameter was effectively removed, while DOC persisted. DOC pass through coincided with an increase in color and $\mathrm{UV}_{254} \mathrm{~nm}$ absorption. In effluents, the $\mathrm{UV}_{254 \mathrm{~nm}}$ transmittance was just below the minimum $65 \%$ disinfection requirement at dilutions greater than $1 \%$. Leachate-impacted wastewater showed a higher concentration of humic-like peaks during fluorescence measurements than wastewater without leachate. 
I dedicate this dissertation to my grandfather Robert William Carbone (04/27/1934-07/13/2015). Thank you for always being so supportive of my graduate studies and for your genunine excitement for all of my accomplishments. We now you would be very proud of this accomplishment. 


\section{ACKNOWLEDGMENTS}

I would like to thank my academic advisor Dr. Debra Reinhart for the opportunity to complete my graduate studies with her. Without her support I would not have had the opportunity to complete my doctorate. I started at UCF thinking I was going to get a MS and never thought getting my $\mathrm{PhD}$ would be possible and so much fun. Dr. Reinhart has been instrumental in increasing my research curiosity and creativity, and has been an extraordinary advisor, mentor, and role model. Research can be very frustrating at times but she taught me to be positive and always reminded me that if research was easy everyone would do it. Her guidance, support, and most importantly her confidence in my abilities have allowed me to fully recognize my potential as a researcher. Thank you for the help building our bioreactors, labeling bottles and vials, and collecting samples with me.

I am also thankful for the many professional networking opportunities, both nationally and internationally, that she has facilitated over the years. I believe we are still questioning why we decided to organize ICLRS. She has always replied to my daily emails and was available for advice despite her very busy schedule. I also appreciated your patience when editing all of my papers. I cannot put into words how proud I am to call Dr. Reinhart my advisor and forever grateful for the opportunity to work with her.

I would like to thank my committee members Drs. Santra, Lee, and Sadmani for their time reading my dissertation and providing valuable feedback. I would also like to acknowledge the Environmental Research and Education Foundation (EREF), Hinkley Center for Solid and Hazardous Waste Management, and the National Science Foundation, for providing funding during my graduate studies. It was an honor to be an EREF scholar. 
Thank you for Kunal Nayee and Duncan Lozinski for their help in the laboratory. Additionally lab work would not possible without the help of lab managers. I would like to thank Maria Real-Roberts (Civil, Environmental, and Construction Engineering Department) and Ernie Gemeinhart (NanoScience Technology Center) for their assistance over the years. Nuclear Magnetic Resonance analysis would not have been possible without the support of Dr. David Richardson (Chemistry Department).

I would also like to thank my friends at UCF: Jackie, Carol Ann, Andrew, David, Paul, and Duncan. Without their friendship I would not have enjoyed graduate school as much as I did. You have provided me with many memories that are priceless.

I am truly thankful for the love and support of my family. My parent's dedication, support, guidance, and immense confidence are the reasons I am the individual I am today. They also told me that I had the ability to achieve anything as long as I put my mind to it and never gave up. My grandparents, Violet, Robert, and Jackie, have also been a constant source of inspiration, support, and guidance. They have never once doubted my abilities and still continue to be proud of my accomplishments. I have a very special relationship with my family and I am truly grateful to have such a strong support system.

Last but not least I am thankful for my husband's support and understanding over the last eight years. This was not a stress-free endeavor and I thank him for always being the one to keep me grounded and focused. I finally did it! 


\section{TABLE OF CONTENTS}

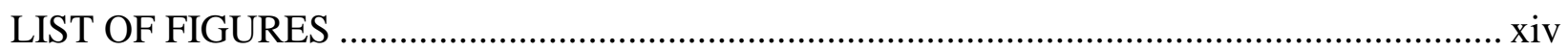

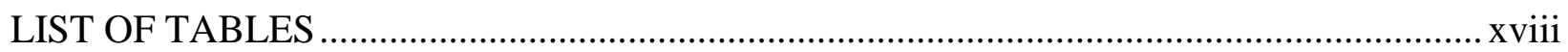

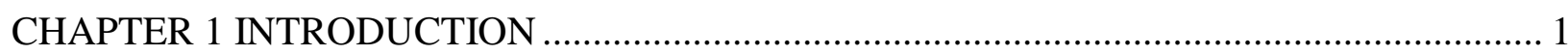

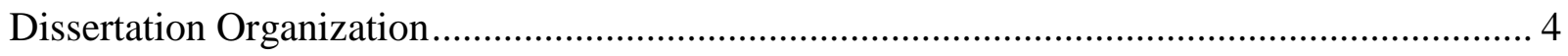

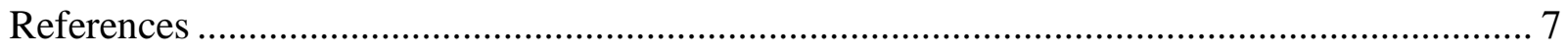

CHAPTER 2 LITERATURE REVIEW ..................................................................... 9

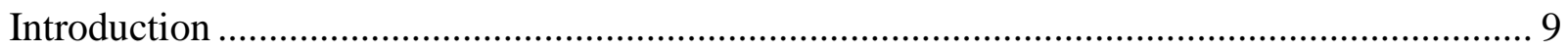

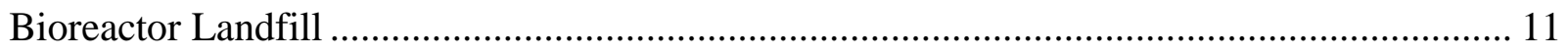

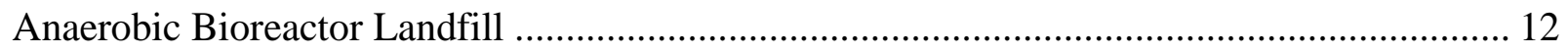

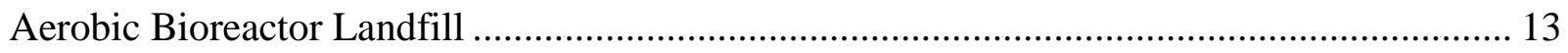

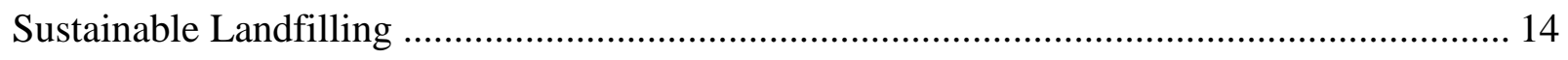

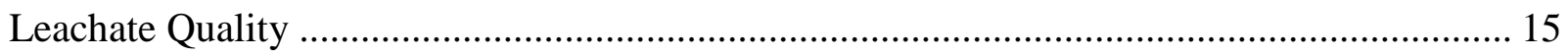

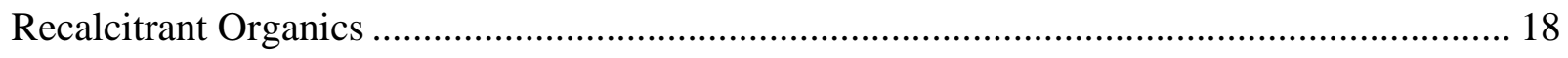

Advanced Oxidation Process: Fenton's Reagent …................................................... 20

Co-Treatment of Leachate and Domestic Wastewater................................................. 21

Municipal Solid Waste Characterization Techniques ..................................................... 23

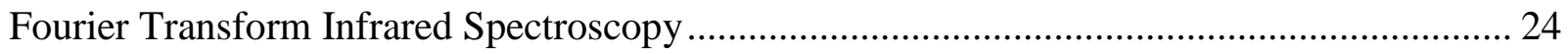

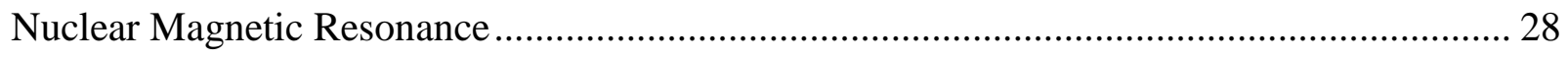

Humic Acid Evolution (Production) and Characterization .............................................. 29

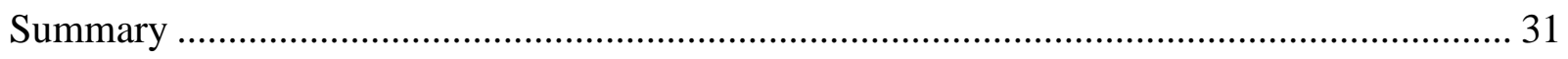

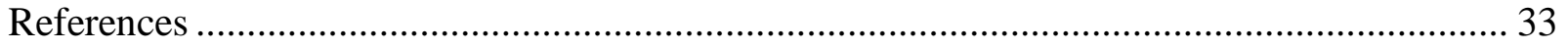


CHAPTER 3 APPLICATION OF LANDFILL TREATMENT APPROACHES FOR THE

STABILIZATION OF MUNICIPAL SOLID WASTE ..................................................... 43

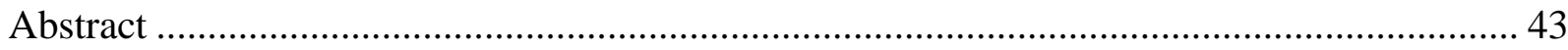

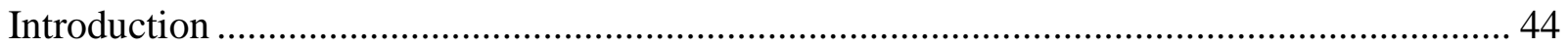

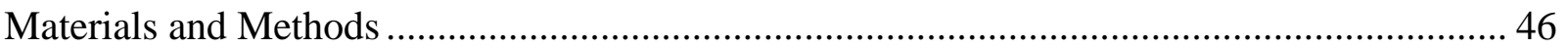

Laboratory-Scale Anaerobic Bioreactor Operation ................................................. 47

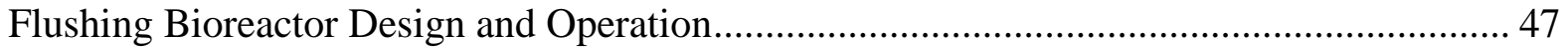

Solid Waste Characterization.................................................................................. 49

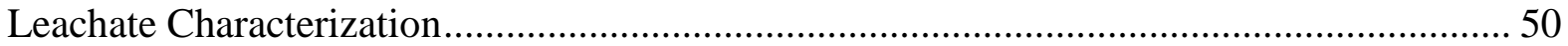

Biochemical Methane Potential ................................................................................. 50

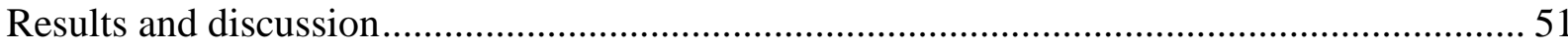

Solid Waste Analysis and Breakdown ..................................................................... 51

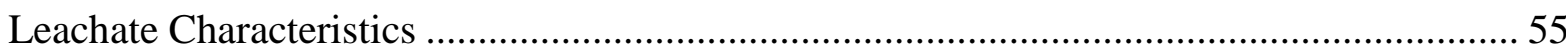

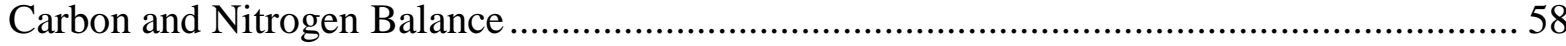

Performance Assessment using Stability Criteria ...................................................... 61

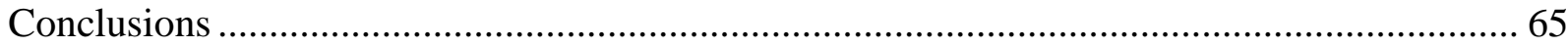

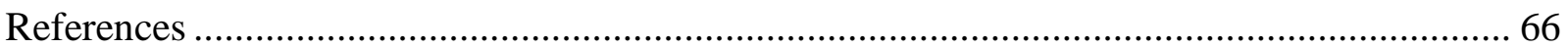

CHAPTER 4 CONVENTIONAL AND FOURIER TRANSFORM INFRARED

CHARACTERIZATION OF WASTE DURING MUNICIPAL SOLID WASTE

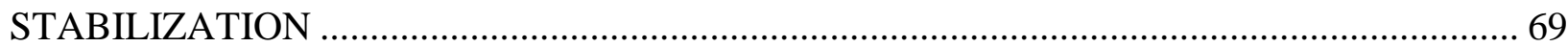

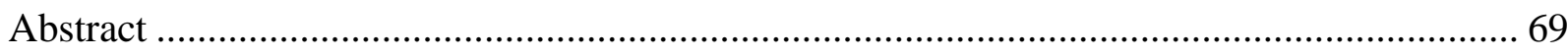

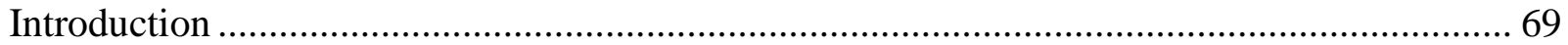

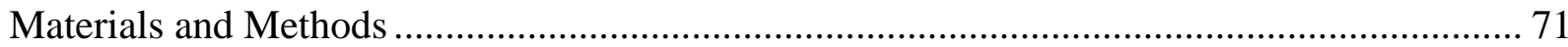




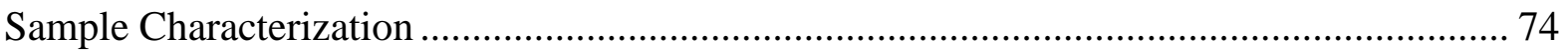

Humic Acid Extraction from Solid Waste ......................................................................... 75

Characterization of Solid Waste and Leachate Using Fourier Transform Infrared

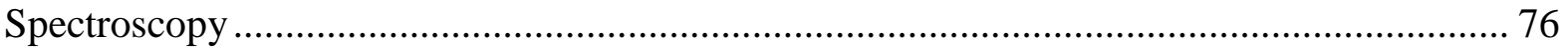

Extracted Humic Acid Characterization using ${ }^{13} \mathrm{C}$ Nuclear Magnetic Resonance .................. 77

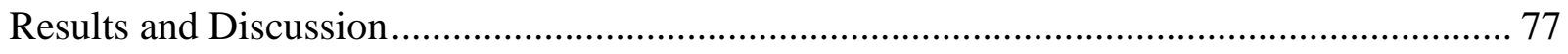

Conventional Solid Waste and Leachate Characterization....................................................... 77

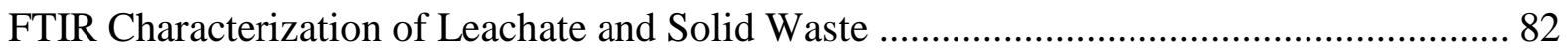

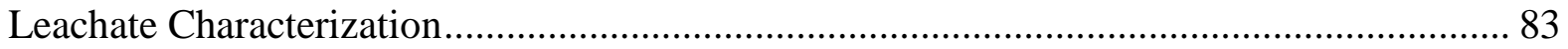

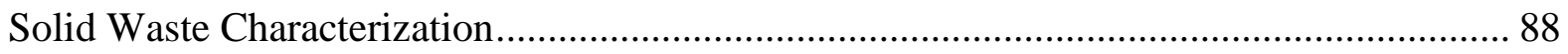

Characterization of Humic Acid Extracted from Solid Waste.................................................. 92

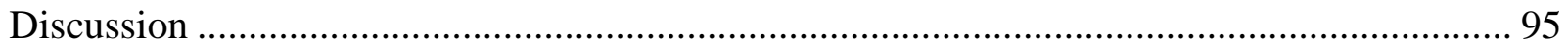

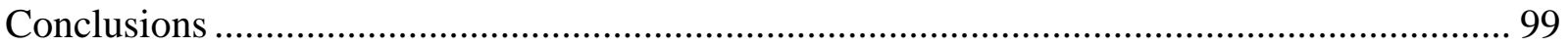

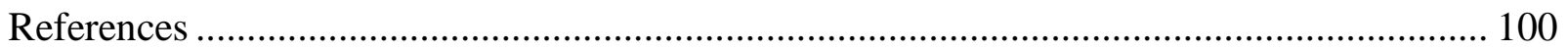

CHAPTER 5 EVALUATION OF LEACHATE DISSOLVED ORGANIC NITROGEN

DISCHARGE EFFECT ON WASTEWATER EFFLUENT QUALITY ................................... 102

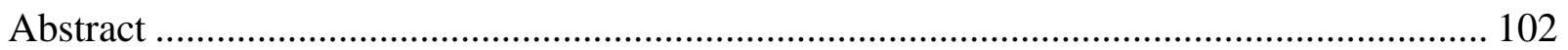

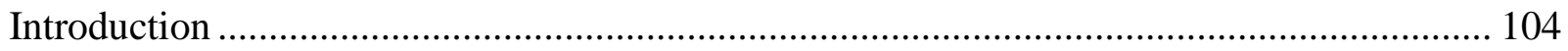

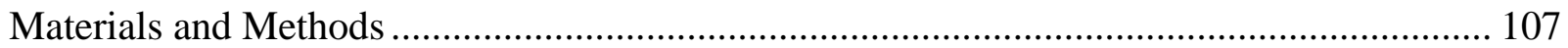

Leachate Collection and Characterization ........................................................................ 107

Assessment of Dissolved Organic Nitrogen Bioavailability Potential using Leachate Organic

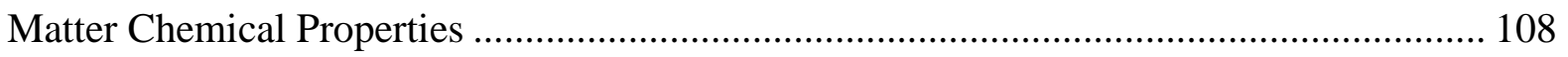

Leachate and Wastewater Co-Treatment Simulations ........................................................... 109 


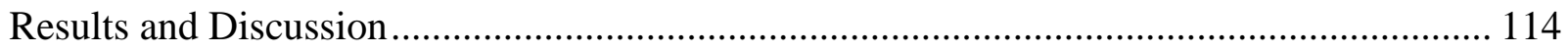

Quantification of Leachate Recalcitrant Dissolved Organic Nitrogen ................................. 114

Impact of Leachate Co-Treatment on Wastewater Effluent Quality .................................. 116

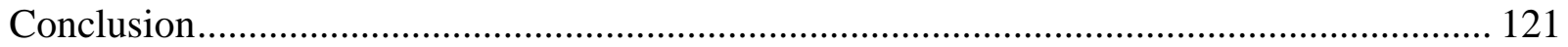

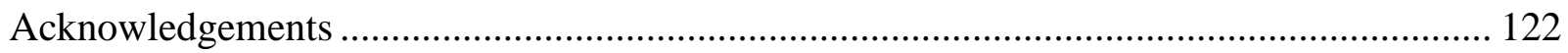

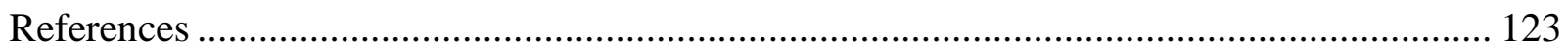

CHAPTER 6 FATE OF ORGANIC MATTER FROM LEACHATE DISCHARGED TO

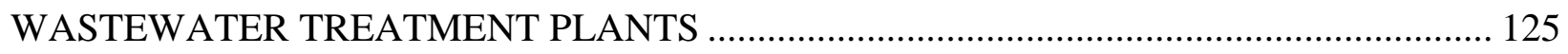

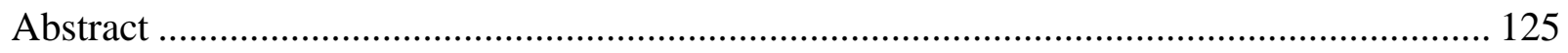

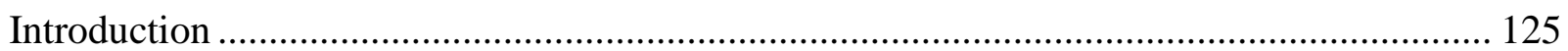

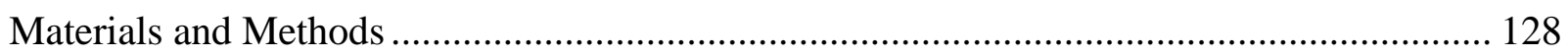

Leachate and Wastewater Characterization and Dilution Study......................................... 128

Field Studies of Leachate and Wastewater Co-Treatment.................................................. 129

Leachate Fingerprinting in Wastewater Effluent ........................................................... 131

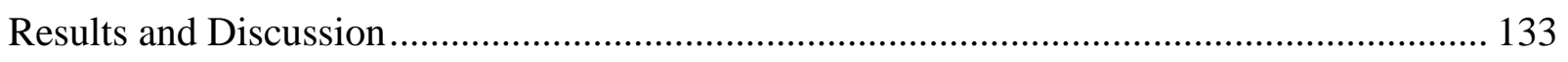

Leachate and Wastewater Characterization ..................................................................... 133

Determination of Leachate Volumetric Contribution using UV-Vis Spectroscopy ............. 137

Field Studies of Leachate and Wastewater Co-Treatment................................................... 139

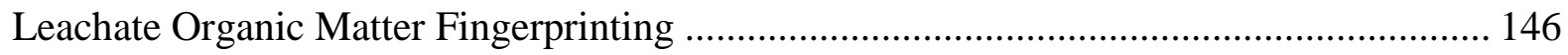

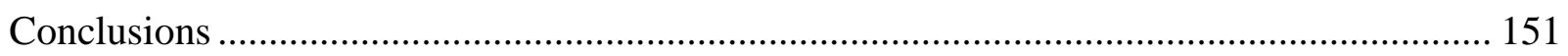

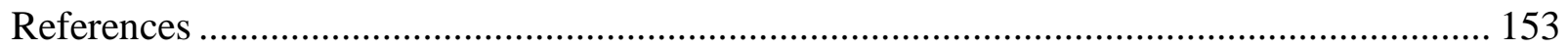

CHAPTER 7 CONCLUSIONS AND RECOMMENDATIONS …………………................. 154

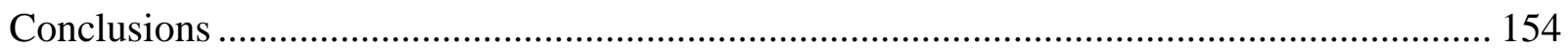




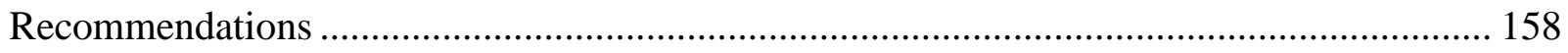

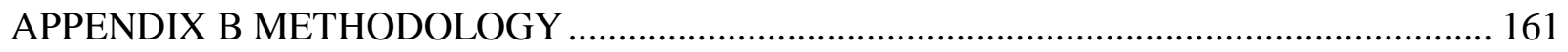

Operating Laboratory Scale Bioreactor to Create a Source of Mature Waste ........................ 162

Operation of Flushing Bioreactors …………………………............................................ 167

Chemical Group and Structural (Molecular) Changes in Solid Waste and Leachate ............. 170

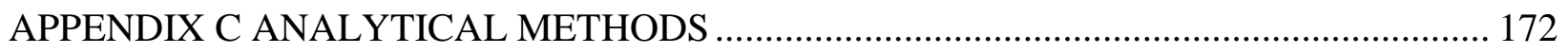

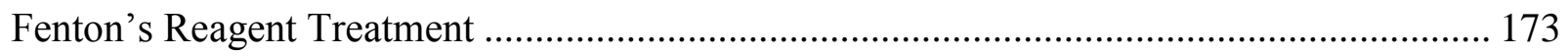

Humic Acid Extraction................................................................................................ 173

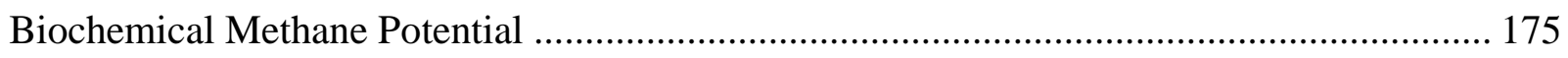

Solid-Phase Extraction of Recalcitrant Dissolved Organic Nitrogen in Leachate .................. 176

APPENDIX D SUPPLEMENTAL INFORMATION: APPLICATION OF LANDFILL

TREATMENT APPROACHES FOR THE STABILIZATION OF MUNICIPAL SOLID

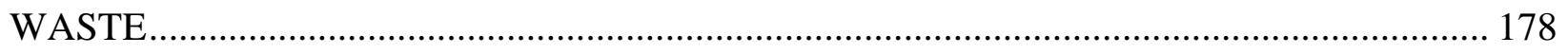

APPENDIX E SUPPLEMENTAL INFORMATION: CONVENTIONAL AND FOURIER

TRANSFORM INFRARED CHARACTERIZATION OF WASTE DURING MUNICIPAL

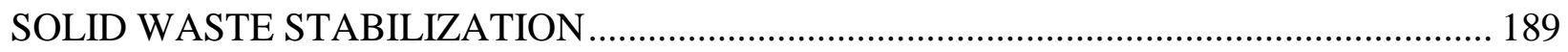

APPENDIX F SUPPLEMENTAL INFORMATION: EVALUATION OF LEACHATE

DISSOLVED ORGANIC NITROGEN DISCHARGE EFFECT ON WASTEWATER

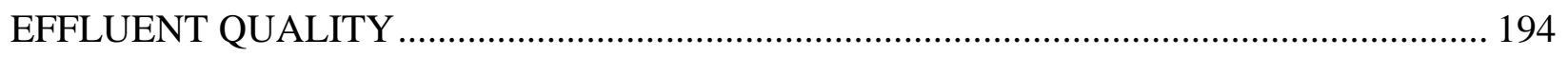

APPENDIX G SUPPLEMENTAL INFORMATION: FATE OF ORGANIC MATTER FROM

LEACHATE DISCHARGED TO WASTEWATER TREATMENT PLANTS .......................... 201 


\section{APPENDIX H ELSEVIER LICENSE TERMS AND CONDITIONS: APPLICATION OF}

LANDFILL TREATMENT APPROACHES FOR THE STABILIZATION OF MUNICIPAL

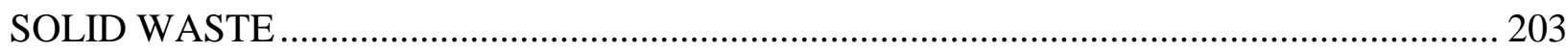




\section{LIST OF FIGURES}

Figure 2-1. Stabilization through Aerobic Bioreactor Leaching ........................................ 10

Figure 3-1. Detailed Flushing Bioreactor Operation ..................................................... 46

Figure 3-2. Distribution of the Final Solid Waste Components Relative to the Mature Waste ... 52

Figure 3-3. Cellulose to Lignin Ratio of Waste Removed from Flushing Bioreactors ............... 54

Figure 3-4. Remaining Methane Potential of Solid Waste Samples from FBs 1-3 ................... 55

Figure 3-5. Ammonia-Nitrogen Concentration in Flushing Bioreactor Scenarios ..................... 57

Figure 3-6. Chemical Oxygen Demand Concentration in Flushing Bioreactor Scenarios .......... 58

Figure 3-7. Summary of the Fate of Carbon in the Biodegradable Waste Fraction (L/S of 10)... 59

Figure 3-8. Summary of the Fate of Nitrogen in the Biodegradable Waste Fraction (L/S of 10) 60

Figure 4-1. Laboratory-Scale Anaerobic Bioreactor Schematic .......................................... 72

Figure 4-2. Simplified Illustration of Flushing Bioreactor Operation (Bolyard and Reinhart,

$2016)$

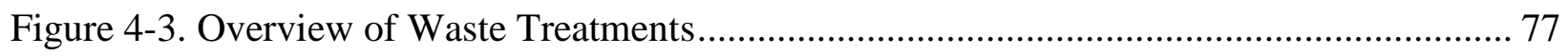

Figure 4-4. Chemical Oxygen Demand and Humic Acid Concentrations from Laboratory-Scale

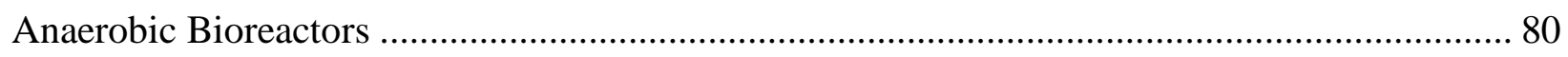

Figure 4-5. BOD $/$ COD Ratio During Waste Treatments and Associated Degradation Phases (Y:

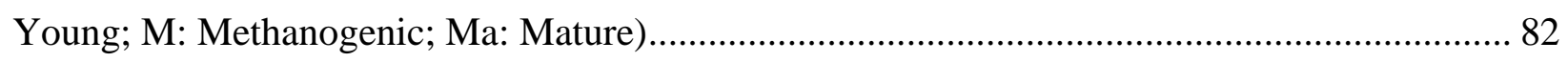

Figure 4-6. PCA Scores Plot of FTIR Spectrum of Anaerobic Bioreactor and FBs 1-3 (L/S of 8-

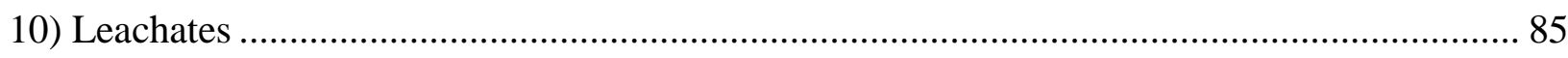

Figure 4-7. PCA Scores Plot of FTIR Spectrum of Initial, Mature, and FBs 1-3 (L/S of 8-10)

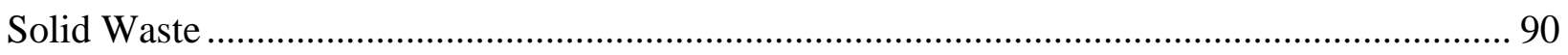

Figure 4-8. Mass of HA Extracted from Solid Waste....................................................... 93 
Figure 4-9. NMR Spectra of HA Extracted from Mature and FB Waste 94

Figure 5-1. DON Fractionation Method ....................................................................... 109

Figure 5-2. Distribution of bDON and rDON Fractions in Leachate ................................... 115

Figure 5-3. Cumulative Frequency of rDON and DON Concentration in Wastewater Effluent at a Leachate Volumetric Contribution of $10 \%$ 120

Figure 5-4. Cumulative Frequency of rDON and DON Concentration in Wastewater Effluent at a Leachate Volumetric Contribution of $1 \%$ 120

Figure 6-1. Treatment and Sampling Scenario 131

Figure 6-2. PCA Scores Plot of FTIR Spectrum of Leachate Samples 137

Figure 6-3. UV 254 Transmittance of Leachate And Wastewater Influent Dilution Tests 138

Figure 6-4. UV 254 Transmittance of Leachate and Wastewater Effluent Dilution Tests...... 139

Figure 6-5. $\mathrm{UV}_{254}$ Absorbance of WWTP 2A and 2B Influent 141

Figure 6-6. WWTP Effluent (WWTP 2A) with and without Leachate (WWTP 2B). 142

Figure 6-7. $\mathrm{UV}_{254}$ Percent Transmittance of Wastewater Effluent with and without Leachate at WWTP 2 143

Figure 6-8. DOC in Wastewater with Leachate (WWTP 2B) Normalized by Wastewater without Leachate (WWTP 2A) 146

Figure 6-9. UV-Vis Scan (200 nm to $800 \mathrm{~nm}$ ) of Wastewater Influent and Effluent Samples with and without Leachate (WWTP 2C). 147

Figure 6-10. UV-Vis Scan (200 nm to $800 \mathrm{~nm}$ ) of Wastewater Influent Samples with Leachate and Effluent without Leachate (WWTP 3) 148

Figure 6-11. Excitation-Emission Figures for WWTP 2A and 2B (with leachate) Effluent Samples Collected at 12:00 am and 4:00 am 149 
Figure 6-12. Relationship between FI, $\mathrm{UV}_{254} \mathrm{~nm}$, and Color for Wastewater Effluent with (2B) and without (2A) Leachate 150

Figure B-1. Anaerobic Bioreactor Schematic 163

Figure B-2. Design that Represents the Three Flushing Bioreactor Scenarios (A) FBs 1 and 2 (B)

Pilot Scale STABL (FB 3) 169

Figure D-1. Design that Represents the Three Flushing Bioreactor Scenarios (A) FBs 1 and 2 (B)

Pilot Scale STABL (FB 3) 180

Figure D-2. Cellulose plus Hemicellulose to Lignin Ratio of Waste Removed from Flushing

Bioreactors 182

Figure D-3. Cost of Treatment based on the Mass of Carbon Removed from Waste...... 186

Figure D-4. Cost of Treatment based on the Mass of Nitrogen Removed from Waste. 187

Figure E-1. Volatile Solids Flushing Bioreactors 1-3 190

Figure E-2. Cellulose/Lignin Ratio Flushing Bioreactors 1-3 190

Figure E-3. Biochemical Methane Potential Flushing Bioreactors 1-3 191

Figure E-4. Spectral Profiles of Anaerobic and Flushing Bioreactors 1-3 Leachates 191

Figure E-5. Loading Plot for Anaerobic Bioreactor and FBs 1-3 (L/S of 8-10) Leachates (A) PC

$191 \%$ Variance and (2) PC 2 Variance $6 \%$ 192

Figure E-6. Loading Plot for Anaerobic Bioreactor and FBs 1-3 (L/S of 8-10) Solid Waste (A)

PC $191 \%$ Variance and (2) PC 2 Variance $6 \%$ 192

Figure E-7. Spectral Profiles of Anaerobic and Flushing Bioreactors 1-3 Solid Waste..... 193

Figure F-1. rDON versus Leachate Total UV 254 nm Absorbance 197

Figure F-2. rDON versus Leachate Dissolved UV 254 nm Absorbance. 198

Figure F-3. Figure F-4. rDON versus Leachate Chemical Oxygen Demand 198 
Figure F-5. rDON versus Leachate Total Nitrogen ....................................................... 199

Figure F-6. rDON versus Leachate Total Kjeldahl Nitrogen ............................................ 199

Figure F-7. rDON versus Leachate Total Humic Acid ................................................... 200

Figure F-8. rDON versus Leachate Dissolved Humic Acid ............................................. 200

Figure G-1. FTIR Spectrum of Dried Leachate Samples .............................................. 202 


\section{LIST OF TABLES}

Table 2-1. FTIR Spectral Peak Assignments for Leachate and Solid Waste............................ 25

Table 2-2. Common Chemical Shift Assignment for Functional Groups of Humic Acid* ........ 29

Table 2-3. Major Functional Groups of Humic Acid ${ }^{*}$...................................................... 30

Table 3-1. Comparison of Solid Waste Stability Indicators ................................................. 61

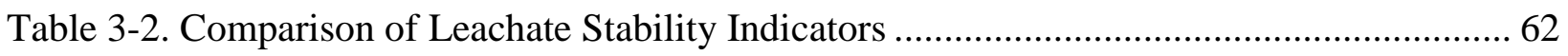

Table 4-1. Anaerobic Bioreactor Waste Composition ......................................................... 72

Table 4-2. Summary of Mature and Flushing Bioreactor Waste Characteristics (Bolyard and

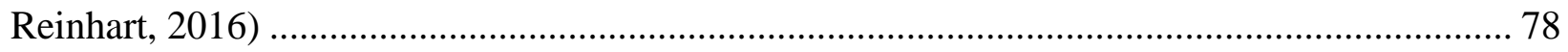

Table 4-3. Characteristics of the Acidogenic, Methanogenic, and Mature Leachate from the

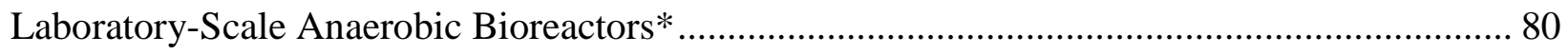

Table 4-4. Characteristics of the Mature and FB Leachate (Bolyard and Reinhart, 2016) .......... 81

Table 4-5. Summary of FTIR Observations for Leachate Samples ........................................ 84

Table 4-6. Summary of Loadings Associated with Principal Components 1 and 2 ................. 85

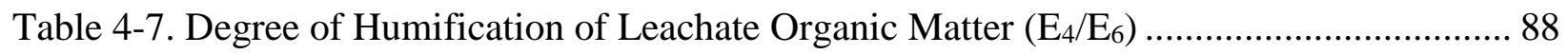

Table 4-8. Summary of FTIR Observations for Solid Waste Samples.................................... 89

Table 4-9. Summary of PCs for Anaerobic and FB Waste Samples ..................................... 90

Table 4-10. Distribution of Carbon of Chemical Shifts of HA Extracted from Waste Removed

from Laboratory-Scale Anaerobic Bioreactors and Flushing Bioreactors ............................... 95

Table 4-11. Comparison of Conventional and FTIR Solid Waste Stability Indicators .............. 97

Table 4-12. Comparison of Conventional and FTIR Leachate Indicators ............................... 98

Table 5-1. Summary of Municipal Solid Waste Landfills and Associated Leachates............... 107 
Table 5-2. Summary of Wastewater Treatment Plant Biological Processes and Influent TN Concentrations $^{\mathrm{a}}$

Table 5-3. Summary of Removal Efficiencies for Nitrogen Species for WWTP 1 ................. 113

Table 5-4. Summary of Removal Efficiencies for Nitrogen Species for WWTP 2 ................. 113

Table 5-5. Summary of Removal Efficiencies for Nitrogen Species for WWTP 3................. 113

Table 5-6. Summary of Removal Efficiencies for Nitrogen Species for WWTP 4................. 113

Table 5-7. Summary of Leachate Total Nitrogen and Dissolved Organic Nitrogen ................. 114

Table 5-8. Summary of bDON and rDON Properties of the Fractionated Leachate Samples ... 116

Table 5-9. Summary of Wastewater Effluent Total Nitrogen as a Function of Leachate

Volumetric Loadings and Fluctuations in Daily Plant Performance (bDON Removal is

Equivalent to TN)

Table 5-10. Summary of Wastewater Effluent Total Nitrogen as a Function of Leachate

Volumetric Loadings and Daily Plant Performance (No Removal of DON) 118

Table 5-11. Maximum Allowable Leachate Total Nitrogen Concentration without Exceeding TN Effluent Limits (Partial bDON Removal) 118

Table 5-12. Maximum Allowable Leachate Total Nitrogen Concentration without Exceeding TN Effluent Limits (Dilution Only)

Table 6-1. Summary of WWTP Sampling Events and Leachate Presence or Absence ............ 130

Table 6-2. Comparison of Leachate (13 Samples) and Influent Wastewater (5 Samples)......... 133

Table 6-3. WWTP Effluent Sample Analysis .................................................................. 134

Table 6-4. Summary of Detected Leachate Functional Groups that Dominated FTIR Spectra . 136

Table 6-5. Principal Component Scores Related to Loading Plots ${ }^{*}$....................................... 137

Table 6-6. Leachate Detection Based on Increase in UV 254 Absorbance ............................... 141 
Table 6-7. Estimated Volumetric contribution Using Known Addition of Leachate Added to Wastewater Influent (without Leachate) .................................................................... 144

Table 6-8. WWTP 2B Leachate Impacted Samples Normalized by WWTP 2A* .................. 145 Table 6-9. WWTP 2B Leachate Impacted Samples* Normalized by Non-Impacted Samples for WWTP2B 145

Table 6-10. Summary of Effluent Characteristics of Samples Collected at 12:00 am and 4:00 am from WWTPs 2A (without leachate) and 2B (with leachate)..... 150

Table B-1. Anaerobic Bioreactor and State of Florida 2009 Waste Composition (FDEP, 2011)

Table B-2. Waste Composition for Reactor 1 ............................................................... 165

Table D-1. Anaerobic Bioreactor Waste Composition ...................................................... 179

Table D-2. Summary of Liquid Addition for Flushing Bioreactors 1-3 .............................. 181

Table D-3. Characteristics of the Mature Leachate used to Initiate Flushing in FBs 2 and $3 \ldots 182$

Table D-4. Characteristics of Anaerobic and Flushing Bioreactors Waste ............................ 183

Table F-1. Summary of Leachates Characterized ........................................................... 195

Table F-2. Summary of bDON and rDON Concentrations and Percent Recovery .................. 196

Table F-3. Calculated Pass through of Leachate rDON and DON in Wastewater Effluent ....... 197 


\section{CHAPTER 1}

\section{INTRODUCTION}

Municipal Solid Waste (MSW) generation reached 1.3 billion tonnes per year globally in 2010 and it is projected to increase to 2.2 billion tonnes per year in 2025 (Hoornweg and BhadaTat, 2012). The increase in waste volume poses a significant challenge to dispose of this waste in a controlled and sustainable manner. Landfilling is still the primary method for waste disposal in both developed and developing countries despite the push to divert waste from landfills. As of 2015, there are approximately 1,637 operating landfills in the U.S. (Gerlat, 2015) and the number of mature landfills will continue to increase.

Modern landfills are designed with engineered containment systems and operated to protect the environment from contamination, but the long-term fate of these containment systems is unknown. The contaminants produced during biological waste stabilization require costly treatment and pose a threat to the surrounding environment should a breach of the engineered containment system occur. These contaminants include ammonia-nitrogen, organic carbon, volatile compounds, and heavy metals (Barlaz et al., 2002; Goi et al., 2010; Kjeldsen et al., 2002; Qasim and Chiang, 1994).

After a landfill has been operated for a period of time and the anaerobically biodegradable organic compounds have degraded, the leachate may contain inorganic contaminants and refractory organic by-products that threaten the environment and human health. Human health and the environment will only be protected as long as the designed containment systems remain intact (Scharff, 2014). If there is a breakdown in the integrity of the containment system long after a site has been released from post-closure care (PCC), moisture 
can be introduced, reinitiating the degradation process, and consequently leachate or gas emissions (Allen, 2001; Scharff, 2010; Tchobanoglous and Kreith, 2002). Therefore, to minimize the long-term environmental impact of landfills, enhanced emission reduction methods are needed prior to a breach of the containment system. It has been suggested that the introduction of liquid (e.g., flushing) and aeration are the best ways to safely reduce or end PCC (Ritzkowski et al., 2006; Stegmann et al., 2003). Flushing has been shown to remove releasable carbon and nitrogen but requires a large volume of water. Two alternative treatment processes have been suggested to reduce the water requirement and leachate treatment as well as costs associated with the conventional means of flushing. Combining in-situ aeration with ex-situ chemical oxidation can remove recalcitrant carbon and biologically convert ammonia-N to nitrate or nitrogen gas.

At present, majority of leachate is co-treated with domestic wastewater due to the cost and complexity of on-site treatment. Biological treatment processes utilized at wastewater treatment plants (WWTPs) are designed to remove carbonaceous biochemical oxygen demand (cBOD) and ammonia-N; these processes are not designed to remove recalcitrant organic matter. Therefore the organic constituents in leachate can be problematic for WWTPs as their recalcitrance causes them to pass through conventional treatment processes, potentially negatively affecting effluent quality (Zhao et al., 2013). Chlorination of these organic compounds can generate toxic disinfection byproducts (e.g., N-Nitrosodimethylamine (Mitch et al., 2003)). An additional concern is that aromatic compounds tend to absorb ultraviolet (UV) light, which may interfere with the alternative method of disinfection of wastewater using UV at volumetric contributions as low as $0.01 \%$ of the WWTP influent (Reinhart and Bolyard, 2015; Zhao et al., 2012).

Nitrogen species such as dissolved organic nitrogen (DON) can be problematic for WWTPs that have to meet lower total nitrogen (TN) limits. After biological treatment, effluent TN is dominated by DON, therefore removal of DON plays an important role in meeting more 
stringent limits. DON concentrations in domestic wastewater effluents, in the absence of other industrial sources, can range from 0.5-2.5 mg/L (Matthews et al., 2011), which can be a significant fraction of TN. There is a need to quantify the concentration of DON in leachate and assess the bioavailability of this species. There has been some research that suggests that recalcitrant DON discharged to aquatic systems can undergo photochemical reactions that promote the production of labile nitrogen species. These species include dissolved primary amines, ammonia-N, and other compounds yet to be identified (Bushaw-Newton and Moran, 1999).

This dissertation focuses on (1) evaluating the application of treatment approaches for the stabilization of MSW, (2) understanding the changes in waste and leachate during stabilization using Fourier Transform Infrared (FTIR) spectroscopy, and (3) determining the effects of leachate organic matter discharged to WWTPs on effluent quality. The treatment approaches for the stabilization of mature landfills were evaluated for the effectiveness of removing releasable recalcitrant carbon and ammonia-nitrogen. Three approaches were evaluated, (1) flushing with deionized water, (2) leachate recirculation with ex-situ chemical oxidation, and (3) leachate recirculation with ex-situ chemical oxidation and in-situ aeration. The latter approach was named Stabilization through Aerobic Bioreactor Leaching (STABL). Batch and modeling studies (Batarseh et al., 2010) demonstrated the economic and technical feasibility of STABL to reduce the long-term liability of mature landfills, but research was necessary to further study this technology. Furthermore, the changes occurring in the waste and leachate during the FB treatments were characterized using FTIR spectroscopy. These changes were correlated to the extent of treatment (determined by the liquid to solids ratio (L/S)) and conventional parameters. $\mathrm{L} / \mathrm{S}$ is the ratio of cumulative volume of clean or treated liquid added per mass of initial dry waste. 
The treatment approaches evaluated in this study were effective at stabilizing solid waste and improving leachate quality. Despite these improvements the generated leachate still requires treatment before discharging to the environment. This research evaluated 12 leachates to quantify TN and DON from landfills across Florida and one in California. These sites represented multiple types of landfills (e.g., conventional, slurry wall) and different ages of waste. The leachate was fractionated based on hydrophilic (bioavailable; bDON) and hydrophobic (recalcitrant; rDON) chemical properties to understand the treatability and potential pass through of these nitrogen species. These data were used to simulate multiple WWTPs using published TN removal efficiencies. Data generated in this study supported the need to further evaluate the impacts of DON on WWTP influent and effluent quality and to determine to what extent LOM interferes with UV disinfection.

Field studies were conducted to increase the understanding of the nature and fate of recalcitrant, UV-absorbing, and organic-nitrogen containing compounds in leachate that is cotreated with domestic wastewater. Leachate and wastewater were characterized for conventional and spectroscopic properties. From these data a molecular fingerprint was developed to allow for the rapid identification of wastewater effluent impacted by LOM. Known additions of leachate to wastewater were used to estimate the volumetric contribution using UV absorbance at $254 \mathrm{~nm}$ as an indicator of the presence of organic matter. Leachate contribution to influent and effluent WWTP DOC, sCOD, and DON concentrations were evaluated by conducting field sampling at WWTPs. These data were used to estimate the extent to which LOM interferes with UV transmittance in WWTP effluents.

\section{$\underline{\text { Dissertation Organization }}$}

This dissertation is organized in seven chapters. Chapter 1 presents introductory information and overview of this research. Chapter 2 provides a literature review and discussion 
regarding bioreactor operation, fate of organic and inorganic waste components, leachate and wastewater co-treatment, and advanced spectroscopic techniques to characterize solid waste, leachate samples, and humic acid (HA).

Chapter 3 describes the results from the application of landfill treatment approaches for the stabilization of MSW. This chapter specifically discusses the fate of carbon and nitrogen during the flushing bioreactor (FB) test scenarios. These results were used to understand to what extent treatment is necessary to further stabilize a mature landfill. Stability indicators were also recommended based on this research. This paper was published in the Waste Management (Impact Factor: 3.22).

Chapter 4 focuses on the extent of waste stabilization based on spectroscopic data from solid waste, leachate, and HA extracted from waste treated under various treatment approaches. These data were compared to conventional biochemical parameters (i.e., solid waste and leachate). Characterizing and better understanding changes in the organic fraction of solid waste during the degradation process is imperative to evaluate the remaining pollution potential (i.e., gas and leachate emissions) and the stabilization of landfilled waste. This information was used to provide better insight as to what happens when mature waste is further stabilized. Spectroscopic stability indicators for both leachate and solid waste were also described. This paper will be submitted to Environmental Science and Technology (Impact Factor: 5.330).

Chapter 5 presents data on total nitrogen (TN) and dissolved organic nitrogen (DON) concentrations in landfill leachate. The effects of leachate nitrogen loadings on the wastewater effluent quality were estimated using a mass balance approach. The bioavailability of DON based on hydrophobic (rDON) and hydrophilic (bDON) chemical properties was estimated. This paper will be submitted to Water Research (Impact factor 5.528). 
Chapter 6 summarizes results from a study that addresses the nature and fate of recalcitrant, UV-absorbing, and organic-nitrogen containing compounds in leachate that is cotreated with domestic wastewater. Wastewater and leachate were characterized to understand the differences in conventional and spectroscopic properties. Leachate nitrogen contribution to effluent WWTP TN concentration permit exceedances were evaluated by conducting field sampling at wastewater treatment plants with and without leachate. This study provided a better understanding of potential implications of accepting leachate for both the landfill and WWTP operators. Additionally, the impediments of disinfection in the presence of LOM were better understood and recommendations were made to ensure that performance complies with permit requirements. This paper will be submitted to Waste Management (Impact factor 3.22).

Chapter 7 contains conclusions and recommendations developed from this research. The appendices provide the detailed methodology and supplemental information, where applicable, for each chapter. 


\section{$\underline{\text { References }}$}

Allen, A. (2001). Containment landfills: the myth of sustainability. Engineering Geology, 60(14), 3-19. doi: http://dx.doi.org/10.1016/S0013-7952(00)00084-3

Barlaz, M. A., Rooker, A. P., Kjeldsen, P., Gabr, M. A., \& Borden, R. C. (2002). Critical Evaluation of Factors Required To Terminate the Postclosure Monitoring Period at Solid Waste Landfills. Environmental Science \& Technology, 36(16), 3457-3464. doi: 10.1021/es011245u

Batarseh, E. S., Reinhart, D. R., \& Berge, N. D. (2010). Sustainable disposal of municipal solid waste: Post bioreactor landfill polishing. Waste Management, 30(11), 2170-2176. doi: http://dx.doi.org/10.1016/j.wasman.2010.06.015

Bushaw-Newton, K., L. , \& Moran, M. A. (1999). Photochemical formation of biologically available nitrogen from dissolved humic substances in coastal marine systems. Aquatic Microbial Ecology, 18(3), 285-292.

Gerlat, A. (2015). EREF Study Sheds New Light on Recycling's Impact. from http://waste360.com/news/eref-study-sheds-new-light-recycling-s-impact

Goi, A., Veressinina, Y., \& Trapido, M. (2010). Fenton Process for Landfill Leachate Treatment: Evaluation of Biodegradability and Toxicity. Journal of Environmental Engineering, 136(1), 46-53. doi: doi:10.1061/(ASCE)EE.1943-7870.0000132

Hoornweg, D., \& Bhada-Tat, P. (2012). What a Waste: A Global Review of Solid Waste Management (Vol. 15).

Kjeldsen, P., Barlaz, M. A., Rooker, A. P., Baun, A., Ledin, A., \& Christensen, T. H. (2002). Present and Long-Term Composition of MSW Landfill Leachate: A Review. Critical Reviews in Environmental Science and Technology, 32(4), 297-336. doi: 10.1080/10643380290813462

Matthews, R., Sharp, R., \& Pitt, P. (2011). Florida's Numeric Nutrient Criteria and the Potential Importance of Dissolved Organic Nitrogen. Paper presented at the Water Environment Federation: Nutrient Management, Miami, Florida.

Mitch, W. A., Gerecke, A. C., \& Sedlak, D. L. (2003). A N-Nitrosodimethylamine (NDMA) precursor analysis for chlorination of water and wastewater. Water Research, 37(15), 3733-3741. doi: http://dx.doi.org/10.1016/S0043-1354(03)00289-6

Qasim, S. R., \& Chiang, W. (1994). Sanitary landfill leachate : generation, control, and treatment: Lancaster, Pa. : Technomic Pub. Co., c1994.

Reinhart, D., \& Bolyard, S. C. (2015). Fate of Organic Matter from Leachate Discharged to Wastewater Treatment Plants (Year 1). Hinkley Center for Solid and Hazardous Waste Management.

Ritzkowski, M., Heyer, K. U., \& Stegmann, R. (2006). Fundamental processes and implications during in situ aeration of old landfills. Waste Management, 26(4), 356-372. doi: http://dx.doi.org/10.1016/j.wasman.2005.11.009

Scharff, H. (2010). Landfill Closure, Aftercare and Final Use Solid Waste Technology \& Management (pp. 932-947): John Wiley \& Sons, Ltd.

Scharff, H. (2014). Landfill reduction experience in The Netherlands. Waste Management, 34(11), 2218-2224. doi: http://dx.doi.org/10.1016/j.wasman.2014.05.019

Stegmann, R., Heyer, K. U., Hupe, K., \& Ritzkowski, M. (2003). Discussion of Criteria for the Completion of Landfill Aftercare. Paper presented at the Sardinia International Waste Management and Landfill Symposium, Sardinia, Italy. 
Tchobanoglous, G., \& Kreith, F. (2002). Handbook of solid waste management McGraw-Hill's AccessEngineering (pp. 1 online resource). Retrieved from http://www.loc.gov/catdir/toc/mh031/2002021284.html

http://www.loc.gov/catdir/bios/mh041/2002021284.html

http://accessengineeringlibrary.com/browse/handbook-of-solid-waste-management-secondedition

Zhao, R., Gupta, A., Novak, J. T., Goldsmith, C. D., \& Driskill, N. (2013). Characterization and treatment of organic constituents in landfill leachates that influence the UV disinfection in the publicly owned treatment works (POTWs). Journal of Hazardous Materials, 258259(0), 1-9. doi: http://dx.doi.org/10.1016/j.jhazmat.2013.04.026

Zhao, R., Novak, J. T., \& Goldsmith, C. D. (2012). Evaluation of on-site biological treatment for landfill leachates and its impact: A size distribution study. Water Research, 46(12), 38373848. doi: http://dx.doi.org/10.1016/j.watres.2012.04.022 


\section{CHAPTER 2}

\section{LITERATURE REVIEW}

\section{$\underline{\text { Introduction }}$}

The bioreactor landfill is an important component of current sustainable waste management practices. Much research has been conducted to create an efficient landfill system that can significantly reduce pollution potential of municipal solid waste (MSW) within a decade (Reinhart et al., 2002; Reinhart and Townsend, 1998). However, after the landfill has been operated for a period of time and the anaerobically biologically degradable organic compounds are removed, the leachate may contain inorganic contaminants and refractory organic byproducts that threaten the environment and human health. In a review of leachate characteristics, Kjeldsen et al. (2002) reported that chemical oxygen demand (COD) in leachates from mature landfills ranged from 500 to $4500 \mathrm{mg} / \mathrm{L}$ and averaged $3000 \mathrm{mg} / \mathrm{L}$ while biochemical oxygen demand (BOD) was well below $200 \mathrm{mg} / \mathrm{L}$. In addition, bioreactor landfill operation tends to yield high ammonia-nitrogen concentrations compared to conventional landfills because recirculating leachate under anaerobic conditions increases the rate of ammonification and provides no major biological pathway for ammonia removal (Berge et al., 2006). Bioreactor ammonia-nitrogen concentrations commonly range from 100 to $1500 \mathrm{mg} / \mathrm{L}$ and average 740 mg/L (Barlaz et al., 2002).

In order to reduce long-term liability and environmental impacts associated with landfills, post-closure care (PCC) of US landfills is now required for 30 years, however this time period may be inadequate. Some researchers suggest PCC may be required for 200 to 500 years (Belevi and Baccini, 1989; Ehrig and Krümpelbeck, 2001). In some cases, removal of both remaining 
organic contaminants and ammonia-nitrogen must be accomplished before landfill PCC can end. Removal of these constituents as they leach from the waste may require a series of costly biological, chemical and physical processes outside of the landfill either at a local treatment plant or using on-site facilities.

To minimize PCC following biological anaerobic digestion of waste in a landfill, a completion phase is proposed. Batch and modeling studies (Batarseh et al., 2010) have preliminarily demonstrated the economic and technical feasibility of the STABL technology, shown in Figure 2-1 (Batarseh et al., 2010).

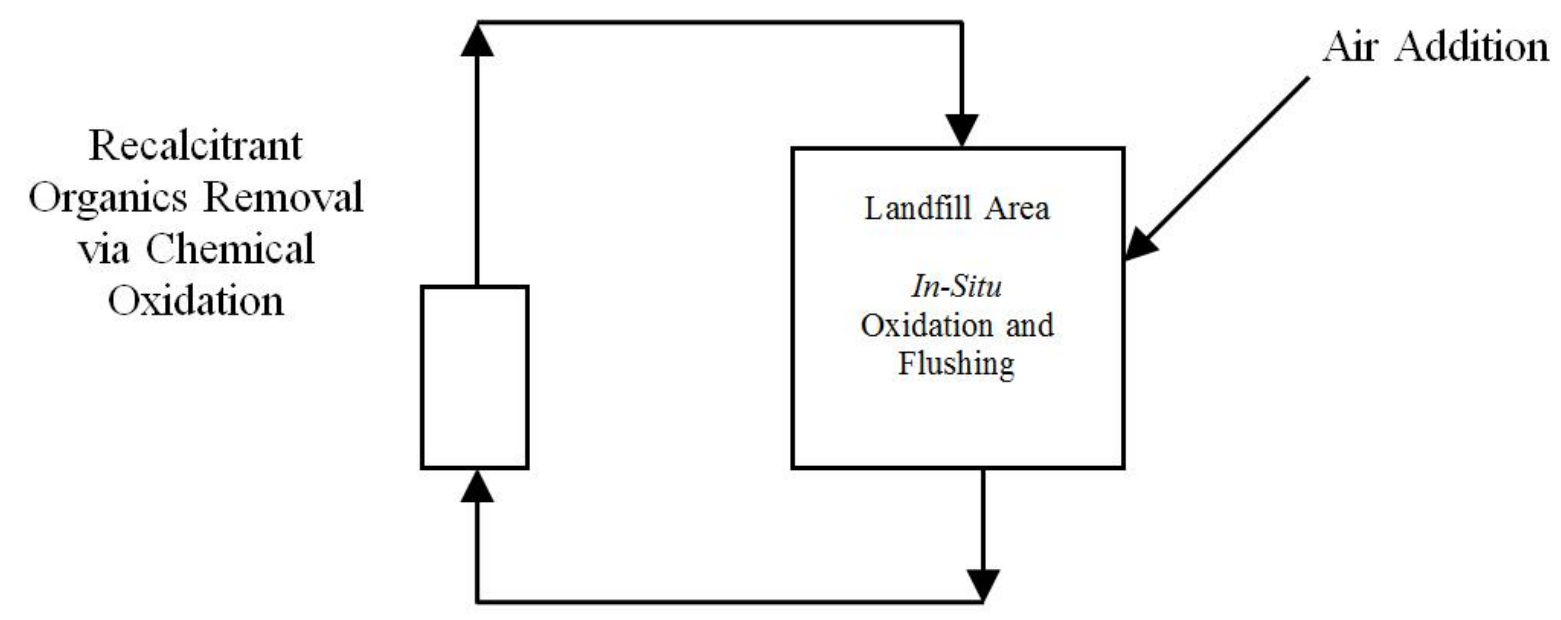

Figure 2-1. Stabilization through Aerobic Bioreactor Leaching

In the STABL, remaining contaminants, such as leachable ammonia-nitrogen and organic contaminants are flushed from the landfill through the recirculation of leachate. Recalcitrant organics are partially oxidized ex situ to the landfill using Fenton's reagent (Batarseh et al., 2007). The oxidized organics are returned to the landfill and treated aerobically in situ, along with ammonia-nitrogen. After this treatment, the ultimate end products remaining in the landfill 
are essentially humic matter and immobilized inorganic compounds. Preliminary cost for this technology was estimated at $\$ 23 /$ metric ton (Batarseh et al., 2010).

\section{Bioreactor Landfill}

Operating a landfill as a bioreactor offers the ability to increase the rate of waste stabilization (Pacey et al., 1999; Reinhart et al., 2002; Warith, 2002). This accelerated stabilization is achieved due to added moisture which facilitates enhanced microbial processes to transform and stabilize the readily and moderately degradable organic constituents within the waste (Warith, 2002). Both laboratory research and field-scale studies suggested that the single most important factor for increasing waste biodegradation is through controlled waste moisture (Pohland, 1975; Warith, 2002). The optimum moisture content for bioreactor landfills is between $40 \%$ and $70 \%$ (Barlaz et al., 1990).

Leachate is a common source of moisture in a bioreactor landfill; recirculation of leachate provides an avenue to reduce the leachate treatment capital and operating costs (Chugh et al., 1998; Doedens and Cord-Landwehr, 1989; El-Fadel, 1999; Kinman et al., 1987; Onay and Pohland, 1998; Reinhart et al., 2002; Šan and Onay, 2001; Tittlebaum, 1982; Townsend et al., 1996; Warith, 2002). Leachate is introduced into a bioreactor by either surface application or injection through vertical wells or horizontal trenches (Khire and Mukherjee, 2007; Reinhart et al., 2002). The liquid requirement is a function of waste characteristics (e.g. field capacity and moisture content), quantity of landfilled waste, and the optimum moisture content for enhanced waste stabilization. In most cases the infiltration of moisture through rainwater or recirculation of leachate is not sufficient to meet the liquid requirement (Reinhart et al., 2002; Warith, 2002). A major drawback to recirculation is the heterogeneity of the landfilled waste and compaction. Wetting is incomplete due to the preferential flow paths and unavoidable inefficiencies in the 
chosen recirculation method (Reinhart et al., 2002). Due to the recirculation of leachate, continuous pumping of two to three times the generation rate is required to avoid a buildup of head on the liner (Reinhart et al., 2002). At times the leachate collection rate may exceed the desired injection rate, which requires alternative options for storage or disposal of leachate outside of the landfill.

Operating a landfill as a bioreactor is an added cost and complexity to daily operations relative to conventional landfilling but can provide avenues for recovering costs over time (Berge et al., 2009; Hater et al., 2001). These cost benefits are seen in increased landfill gas waste to energy conversion, reduction in post-closure care and maintenance requirements, recovery of air space, reduced need for storage and/or treatment of leachate, beneficial reuse of land, and reduction in the contaminating life span of the landfill (Berge et al., 2009; Reinhart et al., 2002; Warith, 2002).

Traditionally bioreactors are operated anaerobically but more recently there have been studies of aerobic landfills. Aerobic landfills offer unique advantages with respect to the waste stabilization process. These advantages include differences in leachate quality and quantity, gas production rates and composition, time required to achieve functional stability, and length of the period required for post-closure care (Warith, 2002).

\section{$\underline{\text { Anaerobic Bioreactor Landfill }}$}

Anaerobic waste stabilization in a landfill is achieved through biological degradation.

The overall waste stabilization process of a landfill occurs in four phases (Barlaz et al., 2002). In the first phase, oxygen in the refuse is depleted and large quantities of carbon dioxide $\left(\mathrm{CO}_{2}\right)$ are produced. During the second phase there is an imbalance between the activity of the hydrolytic bacteria and that of the acetogenic and methanogenic bacteria, which work together to convert 
these intermediates to methane $\left(\mathrm{CH}_{4}\right)$ and carbon dioxide $\left(\mathrm{CO}_{2}\right)$, causing short-chain carboxylic acids to accumulate, leading to a decrease in the $\mathrm{pH}$. There is little solids decomposition during this phase. Methane production mainly begins in the third phase of decomposition resulting in a decrease in the carboxylic acids with corresponding decreases in the leachate COD and $\mathrm{BOD}_{5}$ as well as an increase in $\mathrm{pH}$. During this phase, significant decomposition of cellulose and hemicellulose begins. In the fourth phase of decomposition, the carboxylic acids are depleted and the rate of $\mathrm{CH}_{4}$ production is dependent on the rate of cellulose and hemicellulose hydrolysis. In this phase, the BOD/COD is relatively low $(<0.1)$ because the biodegradable organics have been consumed.

\section{Aerobic Bioreactor Landfill}

An alternative to anaerobic waste stabilization is operating a landfill aerobically through the injection of air. Coupling air injection with leachate recirculation will offer an additional means of increasing the rate of waste decomposition (Green and Hudgins, 2000; Hudgins and March, 1998), reduce methane and volatile organic compound generation, odor emissions, and off-site leachate treatment requirements (Cossu et al., 2003; Raga and R., 2011; Read et al., 2001). The increased rate of waste stabilization can also achieve a higher degree of waste subsidence in comparison to anaerobic conditions translating to recovery of air space (Erses et al., 2008; Stessel and Murphy, 1992).

Under anaerobic degradation ammonia-nitrogen is produced through ammonification, which can cause detrimental effects in the event of an unwanted release of leachate (Berge et al., 2006; Burton and Watson-Craik, 1998; He et al., 2007; Hudgins and March, 1998; Onay and Pohland, 1998; Price et al., 2003). Ammonia-nitrogen concentration will remain constant or 
increase within an anaerobic landfill due to leachate recirculation and the lack of mechanisms anaerobically for in situ removal.

Ammonia-nitrogen in a closed landfill is the key parameter that will affect the ability to release a landfill from regulatory oversight (Heyer et al., 2005). Studies showed that in-situ aeration promoted a dramatic decrease in ammonia-nitrogen concentrations even under low biodegradable $\mathrm{C} / \mathrm{N}$ conditions (Berge et al., 2006; Hao et al., 2009). Heterogeneity of the waste environment does not always allow for uniform distribution of oxygen promoting the formation of anoxic and aerobic pockets. These conditions promote simultaneous nitrification and denitrification to occur within a landfill (Berge et al., 2006; Berge et al., 2007; Giannis et al., 2008; Prantl et al., 2006). Therefore, ammonia-nitrogen can be converted to either nitrate, nitrite, or nitrogen gas.

\section{Sustainable Landfilling}

The overall goal of sustainable landfill is the "ability to meet the needs of the present without compromising the ability for future generations to meet their own needs" (Scharff, 2010b). Sustainability aims to achieve functional stability, which implies that the landfill is in equilibrium with the environment within one generation ( $20-30$ years). If a landfill is in equilibrium with the environment, after the duration of the PCC period, emissions will not cause any degradation of the surrounding environment (Scharff, 2010a; Warith, 2002). Achieving functional stability will require that the waste within the landfill has reached an acceptable final storage quality (Christensen et al., 1992) . Acceptable final storage quality of MSW is not well defined (Döberl et al., 2005; Hjelmar and van der Sloot, 2003). An early definition of acceptable final storage quality stated that the waste residuals should have similar characteristics of the surrounding materials and will not have the potential to produce pollution long term (Baccini, 
1989). The goal of acceptable final storage quality is to achieve a level of waste stability that will not produce emissions that exceed the regulatory thresholds (Valencia et al., 2009).

The European Union (EU) suggests that sustainable landfilling can be achieved either through the flushing bioreactor (FB) or extensive waste preprocessing prior to disposal (European Commission, 1999). In the FB, large amounts of water are needed to completely remove the releasable inorganics, carbon, and nitrogen from the solid waste (IWML-WG, 1999). For example in order to dramatically reduce ammonia it is estimated that approximately two to four liquid bed volumes are required (IWML-WG, 1999). Costs for the FB, however, may be two to four times higher than the conventional landfill due to the additional liquid supply and treatment requirements (Karnik and Parry, 1997). A modification of the FB landfill is proposed in this study.

\section{Leachate Quality}

Landfill leachate is a complex heterogeneous industrial wastewater that varies significantly from landfill to landfill and from time to time. This variation is due to influential factors such as composition and depth of solid waste, age of waste, precipitation rates, and landfill design and operations (Englehardt et al., 2006; Qasim and Chiang, 1994; Tchobanoglous and Kreith, 2002; Worrell et al., 2002). The concentration of leachate constituents peaks within the first two to three years of operation and slowly decreases as the landfill matures; this occurs as organics are removed through washout and waste degradation (Maximova and Koumanova, 2006; Qasim and Chiang, 1994). Organic compounds follow a decreasing trend over time, while it is observed that the inorganic compound concentration tends to vary over time due to adsorption, complexation, precipitation, and dissolution. This specific behavior is responsible for the mobilization or containment of heavy metals within a landfill. 
The age of the landfill can be used to understand waste stabilization and provide information on the soluble components (organics) removed from a landfill (Goi et al., 2010; Qasim and Chiang, 1994). Young leachate is readily biodegradable due to the high BOD/COD ratio (>0.70), while a mature leachate (typically greater than ten years) has a low BOD/COD ratio (<0.1) (Christensen et al., 1992; Englehardt et al., 2006; Kang et al., 2002; Tchobanoglous and Kreith, 2002). Typical characteristics of young leachate are a high BOD and COD concentration (1,000 mg/L-57,000 mg/L and $1500 \mathrm{mg} / \mathrm{L}-71,000 \mathrm{mg} / \mathrm{L}$, respectively), low nitrogen concentration $(<400 \mathrm{mg} / \mathrm{L}$ as $\mathrm{N})$, and total suspended solids (TSS) concentration in the range of $200 \mathrm{mg} / \mathrm{L}-2,000 \mathrm{mg} / \mathrm{L}$ (Kjeldsen et al., 2002; Qasim and Chiang, 1994; Reinhart and Al-Yousfi, 1996). Mature leachate has a higher nitrogen concentration (> $400 \mathrm{mg} / \mathrm{L}$ as $\mathrm{N})$, lower BOD and COD concentration (4-120 mg/L and 3-900 mg/L, respectively), and a reduced TSS concentration relative to young leachate $(100 \mathrm{mg} / \mathrm{L}-400 \mathrm{mg} / \mathrm{L})$.

Metal concentrations in leachate are affected by $\mathrm{pH}$, the presence of organic complexing agents such as humic and fulvic acids, and the presence of inorganic complexing/precipitating agents such as ammonia, carbonates, hydroxides, and chlorides. Studies suggest that a small fraction of these metals in leachate are present as free metal ions. Most metals are associated with organic and inorganic colloidal fractions (Baun and Christensen, 2004). The metals most likely to be found associated with organic colloids are $\mathrm{Cd}, \mathrm{Cr}, \mathrm{Cu}, \mathrm{Pb}$, and $\mathrm{Zn}$. In particular, metals in older leachate form stable complexes with high molecular weight organic components (Calace et al., 2001; Christensen et al., 1996). The speciation of metals will have strong impact on which leachate treatment approaches are most effective at removing metals (Baun et al., 2004). 
Leachate treatment is a major landfill expense; treatment options vary depending on the final disposal options for the leachate (Worrell et al., 2002). The challenge with leachate treatment is designing a process that can adapt to the fluctuations in leachate characteristics from day to day and as the landfill matures (Lu et al., 1985; Qasim and Chiang, 1994). Treatment options for leachate include both on-site and off-site, and both biological treatment and physical/chemical processes (Lu et al., 1985). Off-site treatment involves discharging leachate to a domestic wastewater treatment facility but may require pretreatment prior to discharge (Lu et al., 1985; Qasim and Chiang, 1994).

Biological treatment of leachate utilizes microorganisms to consume soluble and suspended biodegradable organic matter (Barber and Maris, 1984; Qasim and Chiang, 1994; Tchobanoglous and Kreith, 2002). Typical aerobic treatment technologies include activated sludge processes, aerobic sequencing batch reactors, and aerated lagoons (Renou et al., 2008). Anaerobic treatment technologies include digesters and anaerobic sequencing batch reactors which produce $\mathrm{CH}_{4}$ that can be recovered to supplement energy requirements.

Physical and chemical treatment processes are primarily used to remove toxic compounds, color, and suspended solids, and are incorporated downstream of the biological process (Renou et al., 2008). As the age of the landfill increases there is a decrease in biodegradable organics which results in biological processes no longer being a feasible option for treatment (DeWalle and Chian, 1974). Coagulation-flocculation is used to remove recalcitrant organics by inducing flocculation and settlement of dissolved solids. As a result there is a large volume of sludge produced and potentially an increase in the heavy metal concentration in the liquid phase from the added coagulant (Amokrane et al., 1997; Renou et al., 2008; Tatsi et al., 2003). 
Membrane processes are also used to treat landfill leachate and include ultrafiltration, nanofiltration, and reverse osmosis (Renou et al., 2008; Ushikoshi et al., 2002). Ultrafiltration removes macromolecules and particles. A study by Tabet et al. (2002) found that ultrafiltration is not a primary option for treatment but it can be used as pretreatment prior to reverse osmosis. Large molecules can foul membranes commonly used in reverse osmosis thereby decreasing their efficiencies (Syzdek and Ahlert, 1984). Membrane bioreactors can achieve a high effluent quality in a compact design with a high biomass concentration and a low sludge production (Ahmed and Lan, 2012; Bohdziewicz et al., 2008; Renou et al., 2008). Nanofiltration can be used to meet multiple treatment needs, removing both organics and inorganics but can also be impacted heavily by membrane fouling if it is not adequately controlled. Reverse osmosis has been found to be an efficient method for removing pollutants (98-99\% rejection of COD and heavy metals) from leachate at both field and laboratory-scale lined (Bilstad and Madland; Linde et al., 1995).

Overall, biological treatment processes are best utilized to treat ammonia, COD, and heavy metals found in young leachate, while physical/chemical processes are best suited for the removal of recalcitrant organics in mature leachate (Christensen et al., 1992; Renou et al., 2008). Given the increased regulatory discharge requirements for wastewater treatment, combined biological and physical/chemical methods are not always sufficient to meet these stringent standards.

\section{$\underline{\text { Recalcitrant Organics }}$}

Most of the organic carbon that is leachable in landfilled MSW is biodegradable, and therefore can be treated biologically. If a landfill is operated as a bioreactor the biodegradation process can be accelerated (Batarseh et al., 2010). Despite the large fraction of biodegradable 
organic matter, as landfills mature, the remaining refuse is predominately nonbiodegradable (Kjeldsen et al., 2002). Nonbiodegradable xenobiotic organic compounds are present due to improperly disposed waste, along with paints, industrial solvents, used motor oils, cleaning agents, and insecticides (Reinhart, 1989). A larger source of nonbiodegradable carbon is humic substances (HS). HS are commonly categorized by three main components; humic acid (HA) (base soluble and acid insoluble), fulvic acid (acid and base soluble), and humin which is insoluble. HS are present in landfills as byproducts of the biological degradation of refuse. The accumulation of HS most significantly contributes to the shift in the degree of biodegradability of leachate as the landfill ages (Kjeldsen et al., 2002). HS are known to significantly affect the behavior of trace contaminants in aquatic environments. The main avenue for transport of pollutants from within a landfill is due to the affinity of HS for heavy metals and organic pollutants such as pesticides, insecticides and herbicides (Kang et al., 2002; Nanny and Ratasuk, 2002). HS also play a role in the degradation of water quality as they can contribute to odor and taste issues and color. HS can also contribute to the creation of disinfection byproducts (Kang et al., 2002; Katsumata et al., 2008). 


\section{$\underline{\text { Advanced Oxidation Process: Fenton's Reagent }}$}

The organic load and toxicity in waters and wastewaters have been successfully reduced through the use of advanced oxidation processes (AOPs) (Alaton et al., 2002; Batarseh et al., 2007; Guzzella et al., 2002; Wu et al., 2010). These AOPs are based on the generation of hydroxyl free radicals from the combination of hydrogen peroxide or ozone with ultraviolet radiation or a catalyst. Hydroxyl free radicals convert organics to carbon dioxide and water due to their high electrochemical oxidant potential. Common reactions that can be used to generate these hydroxyl free radicals are Fenton Reagent, photo-Fenton, ozone/UV, hydrogen peroxide/UV, and titanium dioxide/hydrogen peroxide/solar radiation (Batarseh et al., 2007; Benitez et al., 2001; Höfl et al., 1997; Pérez et al., 2002; Rodriguez et al., 2001; Sarria et al., 2001).

Fenton's Reagent is the combination of hydrogen peroxide and ferrous salts which generate hydroxyl free radicals under acidic conditions (Equation 2-1) (Batarseh et al., 2007; Deng and Englehardt, 2006; Primo et al., 2008; Tekin et al., 2006; Umar et al., 2010; Wu et al., 2010).

$$
\mathrm{Fe}^{2+}+\mathrm{H}_{2} \mathrm{O}_{2} \rightarrow \mathrm{Fe}^{3+}+\mathrm{OH}^{-}+\mathrm{OH}
$$

During this reaction $\mathrm{Fe}^{2+}$ can be regenerated by reacting $\mathrm{Fe}^{3+}$ with excess hydrogen peroxide and hydroperoxyl radicals (Equations 2-2 and 2-3). Fenton's Reagent has a short reaction time in comparison to other AOPs which makes this process ideal when high COD removal is desired (Sarria et al., 2001).

$$
\begin{gathered}
\mathrm{Fe}^{3+}+\mathrm{H}_{2} \mathrm{O}_{2} \rightarrow \mathrm{Fe}^{2+}+\mathrm{H}^{+}+\mathrm{HO}_{2} \\
\mathrm{Fe}^{3+}+\mathrm{HO}_{2} \cdot \rightarrow \mathrm{Fe}^{2+}+\mathrm{H}^{+}+\mathrm{O}_{2}
\end{gathered}
$$


Fenton's Reagent has been successfully applied to the treatment of landfill leachate, textile wastewater, polynuclear aromatic hydrocarbons, brines, paper pulp manufacturing effluents, activated sludge, and 1-amino-8-naphthol-3,6-disulfonic acid manufacturing wastewater (Batarseh et al., 2007; Beltrán et al., 1998; Kang et al., 2002; Pérez et al., 2002; Rivas et al., 2003).

Leachate treatment by Fenton's reagent has proven to be quite effective (Batarseh et al., 2007; Deng and Englehardt, 2006; Primo et al., 2008; Tekin et al., 2006; Umar et al., 2010; Wu et al., 2010). Removal of COD in leachate has been report between 50\%-98\% from Fenton's reagent (Bae et al., 1997; Ghanbarzadeh Lak et al., 2012; Tekin et al., 2006; Xie et al., 2010).

Numerous studies focused on determining the optimum dosage for COD removal to minimize unnecessary usage of chemicals. The recommended conditions for treatment are $\mathrm{pH}$ of 4.0 S.U. and a $\mathrm{Fe}^{2+} / \mathrm{H}_{2} \mathrm{O}_{2}$ of 0.4 (Batarseh et al., 2007; Deng and Englehardt, 2006; Kang et al., 2002; Marañón et al., 2008; Singh and Tang, 2013; Wu et al., 2010). At the recommended conditions, it was found that for every $1 \mathrm{~g}$ of added iron, $0.7-1 \mathrm{~g}$ of COD were removed (representing 70-80\% of the COD present). However, $68-78 \%$ of that removal is by precipitation with iron hydroxide. Therefore, these precipitates must be stabilized at high $\mathrm{pH}$ and disposed in a landfill.

\section{Co-Treatment of Leachate and Domestic Wastewater}

A number of studies have reported successful co-treatment of leachate and wastewater at volumetric contributions less than $\sim 10-20 \%$ of influent flow rates (Cecen and Cakiroglu, 2001; Reinhart et al., 1994). The removal of leachate constituents during co-treatment is a function of the leachate characteristics and the processes provided (Bu et al., 2010). Biological treatment removes readily degradable organics including DON related to proteins and amino acids. A 
literature review by Kurniawan et al. (2010), however, concluded that no single physicalchemical process was capable of completely removing organic contaminants in stabilized leachates. Studies by Robinson et al. (2013) reported poor removal of "hard" COD by sequencing batch reactors and that ultrafiltration was necessary for treatment to acceptable levels.

Because of the inefficiency of single treatment processes, some of these recalcitrant contaminants will likely pass through WWTPs with only conventional secondary treatment. Much of the recalcitrant organic constituents in leachate are aromatic and UV absorbing (Zhao et al., 2013) and capable of mobilizing metals and other organic contaminants (Kjeldsen et al., 2002).

A 2011 report to the Water Environment Research Foundation (WERF) (Bott and Parker, 2011) evaluated the performance of 22 WWTPs designed to remove nitrogen and phosphorous. The study reported that the reliability for achieving organic nitrogen levels of $1.0-1.5 \mathrm{mg} / \mathrm{L}$ ranged from 10 to $91 \%$. Removal of nitrogen is highly dependent on the type of technology provided. For example, Bott and Parker (2011) report that separate-stage N removal outperforms combined $\mathrm{N}$ removal facilities and four or five-stage Bardenpho plants were effective in achieving low TN goals. Warm climate typical of Florida contributed to higher reliability and lower effluent nitrogen. Leachate DON, which is characterized by small molecular weight that may not be removed effectively in conventional activated sludge processes (Chen et al., 2010), will be particularly problematic for WWTPs with low TN limits. Further, chlorination of DON has been attributed to the formation of N-Nitrosodimethylamine, a potent carcinogen, and other disinfection by-products (DBPs) and to membrane fouling (Pehlivanoglu-Mantas and Sedlak, 
2008). They also reported that DON in the environment can be converted to forms that support microbial growth, leading to eutrophication.

\section{Municipal Solid Waste Characterization Techniques}

Changes in the organic fraction of solid waste during the degradation process will affect the remaining pollution potential (and liability) of a landfill. The change in chemical composition can be measured by conventional indicators such as the concentration of cellulose, hemicellulose or lignin; the ratio of cellulose to lignin; or the ratio of cellulose plus hemicellulose to lignin. Other traditional indicators of biological stability are methane potential (Owen et al., 1979), leachate $\mathrm{pH}$, organic carbon content, respiration activity, humic acid evolution, and the relative presence of different nitrogen compounds (Castaldi et al., 2005; Chefetz et al., 1998; GonzálezVila et al., 1999; Lguirati et al., 2005; Smidt et al., 2011; Smidt et al., 2005; Wu et al., 2010). These indicators have all been used to estimate the extent of waste degradation but the point at which all waste is completely degraded and the landfill has reached functional stability is not yet clearly defined.

Advanced analytical techniques which have been employed to further analyze the extent of decomposition process of refuse components, especially wood and paper, utilize state-of-theart instrumentation such as High Performance Liquid Chromatography, Nuclear Magnetic Resonance, FTIR, thermal analysis (Thermogravimetry and differential scanning calorimetry) and Tetramethyl-ammonium Hydroxide Thermo-chemolysis gas chromatography mass spectrometry. Collectively these analytical tools permit characterization and quantification of cellulose and hemicellulose (Barlaz, 2006), organic compound speciation (Baldock and Skjemstad, 2000), lignins (Nanny and Ratasuk, 2002), and thermal properties (FTIR 
spectroscopy and simultaneous thermal analysis, (Smidt et al., 2005)). FTIR techniques were used in this study and will be described relative to their use in waste processing and degradation. Fourier Transform Infrared Spectroscopy

Understanding waste degradation at the molecular level can provide more comprehensive information to assess the extent of stabilization or degradation of waste. The complexity of waste samples proposes challenges to strictly using conventional analytical methods. Understanding solid waste stability is a complex process since the extent of stabilization can be determined using various physical, biological, and chemical properties (Smidt et al., 2002).

FTIR is one of the more promising techniques to characterize waste stabilization. FTIR has been extensively used in organics characterization to evaluate waste maturity during the composting process (Amir et al., 2010; Cuetos et al., 2010; Ouatmane et al., 2000). FTIR provides data on the chemical compound functional groups, which can be used to describe the changes in the chemical composition at the molecular level of the waste during stabilization. FTIR generates a very specific chemical fingerprint of the sample, which is dependent on the shape, size, and presence or absence of spectral bands that can be correlated to specific degradation phases (Smidt et al., 2011). Table 2-1 summarizes common spectral peaks found during FTIR analysis of leachate and solid waste. 
Table 2-1. FTIR Spectral Peak Assignments for Leachate and Solid Waste

\begin{tabular}{|c|c|c|}
\hline Wavenumber $\left(\mathrm{cm}^{-1}\right)$ & Vibration & Functional Group or Compound \\
\hline $3700-3200$ & SiO-H Stretching & Silica $^{1}$ \\
\hline $3700-3400$ & $\mathrm{O}-\mathrm{H}$ stretch & $\begin{array}{c}\text { Bonded and non-bonded hydroxyl groups and } \\
\text { water }^{2}\end{array}$ \\
\hline $3372-3381$ & $\begin{array}{l}\text { O-H Stretching, N-H } \\
\text { Stretching } \\
\end{array}$ & $\begin{array}{c}\text { Phenols, alcohols, and carboxylic acids, amides } \\
\text { and amines }{ }^{1}\end{array}$ \\
\hline $3180-3090$ & $\mathrm{NH}_{2}$ stretch & Primary amides ${ }^{3,4}$ \\
\hline 2981 & $\mathrm{C}=\mathrm{C}$ Stretching & Aromatic $^{5}$ \\
\hline $2931-2936$ & C-H Stretching & $\begin{array}{l}\text { Methylene, Aliphatic Structures (Fatty Acids, } \\
\text { Waxes) })^{1,6}\end{array}$ \\
\hline 2850 & C-H Stretching & Methylene, Aliphatic $6,17,18,19$ \\
\hline $2590-2560$ & S-H stretch & Thiol group ${ }^{3,4}$ \\
\hline 2520 & N/A & Carbonate $^{7}$ \\
\hline $1740-1700$ & $\mathrm{C}=\mathrm{O}$ & Aldehyde, ketone, carboxylic acids, esters ${ }^{6,8,9,10}$ \\
\hline $1685-1630$ & $\begin{array}{c}\mathrm{C}=\mathrm{O}, \mathrm{COO}-\text { stretching, } \mathrm{C}=\mathrm{C} \\
\text { stretching }\end{array}$ & $\begin{array}{c}\text { Amide I, carboxylates, aromatic ring modes, } \\
\text { alkenes }^{1}\end{array}$ \\
\hline $1654-1645$ & $\mathrm{C}=\mathrm{O}, \mathrm{C}=\mathrm{C}$ & $\begin{array}{c}\text { Amide I, Carboxylates, Aromatic ring modes, } \\
\text { alkenes }{ }^{5,8,9,10}\end{array}$ \\
\hline 1635 & $\mathrm{O}-\mathrm{H}$ Bending & Absorbed Water ${ }^{2,1}$ \\
\hline $1600-1590$ & $\mathrm{C}=\mathrm{C}$ & Aromatic Skelton $^{1}$ \\
\hline 1560,1546 & $\mathrm{~N}-\mathrm{H}$ in Plane & Amides II ${ }^{8,9,12,13}$ \\
\hline $1515-1505$ & Aromatic skeletal & Lignin from Lignoccellulosic Materials ${ }^{8,14}$ \\
\hline $1450-1410$ & N/A & Carbonate $^{4,3}$ \\
\hline $1430-1420$ & COO-stretch & Carboxylic Acids, Carbonate 6,10 \\
\hline 1384 & N-O Stretch & Nitrate (Leachate) $)^{1,6,11,15}$ \\
\hline $1350-1250$ & $\mathrm{C}-\mathrm{N}$ & Primary and secondary aromatic amines ${ }^{2,3}$ \\
\hline 1320 & C-N Stretch & Aromatic Primary and Secondary Amines ${ }^{15}$ \\
\hline 1295 & C-N Stretch & Amides $^{17}$ \\
\hline $1265-1240$ & $\mathrm{C}-\mathrm{O}, \mathrm{C}-\mathrm{N}$ & Carboxylic acids, Amide III ${ }^{15}$ \\
\hline $1250-900$ & $\mathrm{C}-\mathrm{O}-\mathrm{C}, \mathrm{C}-\mathrm{O}, \mathrm{C}-\mathrm{O}-\mathrm{P}$ & Polysaccharides, Phosphodiesters ${ }^{9,12}$ \\
\hline $1140-1080$ & S-O Stretching & Sulfate $^{2,3}$ \\
\hline 1114 & C-O Stretching & Secondary Alcohols, Ethers ${ }^{5}$ \\
\hline 1080 & N/A & Quartz $^{1,11,15,16}$ \\
\hline 1030 & Si-O Stretch, Si-O-Si & Clay Minerals ${ }^{1,15,16}$ \\
\hline 875 & C-O Out of Plane & Carbonate $^{11,15}$ \\
\hline 713 & C-O Out of Plane & Carbonate $^{1}$ \\
\hline 706 & N-H Out of Plane & Amide $^{17}$ \\
\hline $680-610$ & S-O bend & Inorganic sulfates $^{1}$ \\
\hline
\end{tabular}

1. Smidt et al. (2005), 2. Socrates (2007), 3. Hajjouji et al., 2008, 4. Kang et al. (2002), 5. He et al. (2011), 6. Piccolo et al. (1992), 7.

Tseng et al. (1996), 8. Ouatmane et al. (2000), 9. Naumann et al. (1996), 10. Hesse et al. (2005), 11. Madejová (2003), 12. Grube et al. (1999), 13. Nanny and Ratasuk (2002), 14. Faix (1991), 15. Smith (1999), 16. Bosch et al., 2002, 17. Smidt et al. (2005), 18. Castaldi et al. (2005), 19. Hafidi et al. (2005) 
The approach described in this research is based on the concept of 'functional stability,' which is a term used to define when a "closed landfill does not present an unacceptable threat to human health and the environment in the absence of active care and regulatory oversight" (Morris and Barlaz, 2011). The published spectral peaks, summarized in Table 1, were used to identify the functional groups of solid waste, leachate, and HA during waste stabilization. It is hypothesized that functional stability will be evident when the aforementioned spectral peaks reach a constant intensity over time and the spectra are dominated by inorganic functional groups.

Early on in the landfill degradation process, a band at $1740 \mathrm{~cm}^{-1}(\mathrm{C}=\mathrm{O}$ stretch of aldehydes, ketones, and esters) disappears signifying the breakdown of readily biodegradable materials (Smidt et al., 2005). The microbial biomass spectral bands at 1570 and $1540 \mathrm{~cm}^{-1}$ are strong for MSW (Smidt et al., 2005). Lignin present from lignocellulosic materials generates a weak band at $1512 \mathrm{~cm}^{-1}$ (Smidt et al., 2005). Inorganic nitrates will produce spectral bands at $1384 \mathrm{~cm}^{-1}$ and will be present in solid waste as the landfill matures (Madejová, 2003; Piccolo et al., 1992; Smith, 1999). Clay materials $\left(1030 \mathrm{~cm}^{-1}\right)$ and quartz $\left(1080 \mathrm{~cm}^{-1}\right)$ are predominately found in the inorganic fraction of MSW; this fraction will be predominately found in the region between 900 and $1100 \mathrm{~cm}^{-1}$ (Socrates, 2007).

Smidt et al. (2011) characterized solid waste from an "unknown" landfill. This sample had a $32.9 \%$ organic content yet they reported that the landfilled materials produced a spectrum that was dominated by calcite spectral bands. Spectral bands produced by natural organic matter can be observed at $2900 \mathrm{~cm}^{-1}$ and in the range of $900-1200 \mathrm{~cm}^{-1}$. An additional measure of the organic matter stability in this study was the ratio of the relative intensities of the aliphatic methylene bands (stabilized components; $2920 \mathrm{~cm}^{-1}$ ) and aromatic or unsaturated $\mathrm{C}=\mathrm{C}$ vibrations 
(unstabilized components; $1640 \mathrm{~cm}^{-1}$ ). Smidt et al. (2011) observed a decrease in aliphatic methylene bands (2920 and $2850 \mathrm{~cm}^{-1}$ ), which was a specific indicator of the progression of the waste degradation process. As this process approaches complete stabilization a constant intensity of the spectral bands relative to the other will be maintained during characterization suggesting that the sample is no longer reactive as supported by the decrease in unstabilized functional groups $(\mathrm{C}=\mathrm{C})$. This trend will support that the solid waste has reached acceptable final storage quality.

Leachate has also been characterized using FTIR to track the waste stabilization and remediation processes (e.g. aeration of old landfills). Aerobic and anaerobic landfills produce leachate with different characteristics. An anaerobic environment produces leachate with inorganic nitrogen and sulfur components whereas aerobic environments have bands representative of sulfate and nitrate compounds. Inorganic nitrogen is characterized by symmetric and asymmetric N-H stretches above $3000 \mathrm{~cm}^{-1}, \mathrm{~N}-\mathrm{H}$ bend (in plane) at $1600 \mathrm{~cm}^{-1}, \mathrm{C}$ $\mathrm{N}$ stretching at $1295 \mathrm{~cm}^{-1}$, and N-H bend (out of plane) at 834 and $706 \mathrm{~cm}^{-1}$ (Smidt et al., 2011) (Grube et al., 1999; Nanny and Ratasuk, 2002; Naumann et al., 1996; Ouatmane et al., 2000). Organic sulfur is evident from the S-H stretching at $2575 \mathrm{~cm}^{-1}$ (El Hajjouji et al., 2008; Kang et al., 2002; Smidt et al., 2005). Sulfate is evident from spectral peaks for the S-O stretch at 1100 $\mathrm{cm}^{-1}$ and S-O bend at $616 \mathrm{~cm}^{-1}$ (Smidt et al., 2005), while nitrate spectral peaks are present from N-O stretching at $1400 \mathrm{~cm}^{-1}$ (Smidt et al., 2005; Smith, 1999).

The general indicators of waste stability from the referenced studies were amide II (1560, $\left.1320,1260-1240 \mathrm{~cm}^{-1}\right)$, aliphatic methylene $\left(2920 \mathrm{~cm}^{-1}\right.$ and $\left.2850 \mathrm{~cm}^{-1}\right)$, and carbonate spectral peaks (1425 and $875 \mathrm{~cm}^{-1}$ ) (Smidt et al., 2005; Smidt et al., 2002). These spectral peaks were 
identified as indicators of waste stability as they underwent the most change and were also stability indicators recognized in compost stabilization and HA characterization studies.

\section{$\underline{\text { Nuclear Magnetic Resonance }}$}

NMR is another characterization technique that has been used to understand the humification process and waste stability (Caricasole et al., 2011; El Hajjouji et al., 2008;

Fukushima et al., 2009; Gonzalez et al., 1999; Lguirati et al., 2005; Lorenz et al., 2012; Sen and Chandra, 2007). During NMR analysis magnetic nuclei absorb and re-emit electromagnetic radiation. The energy at a specific frequency is dependent on the strength of the magnetic field and the magnetic properties of sample to be analyzed (Jacobsen, 2007). The specific frequencies in NMR are referenced to an internal standard $\left(\mathrm{D}_{2} \mathrm{O}\right)$ which is translated to each chemical shifts

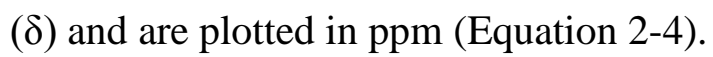

$$
\begin{gathered}
\delta=\frac{\text { differences between a resonance frequency and the reference }}{\text { operating frequency of the spectrometer }} \\
\qquad=\frac{500 \mathrm{~Hz}}{500 \mathrm{MHz}}=\frac{1}{1 \times 10^{-6}}=1 \mathrm{ppm}
\end{gathered}
$$

The common peak assignments for the chemical shifts are summarized in Table 2-3. NMR chemical shifts can be used to determine the structural changes that occur as the waste degradation proceeds and to understand the humification process as a means of determining the extent of biological stability. This is possible since NMR can characterize the chemical changes and formations occurring during stabilization (Sen and Chandra, 2007). A study by Lguirati et al. (2005) found that HA samples showed a strong chemical-shift in the aliphatic regions (0-105 ppm) and aromaticity (140-160 ppm). As the waste degradation proceeds towards stability increased polymerization (aromaticity; 110-140 ppm) and the decrease in acidic functional groups (carboxylic groups; 160-220 ppm) will occur. 
Table 2-2. Common Chemical Shift Assignment for Functional Groups of Humic Acid*

\begin{tabular}{|c|c|}
\hline Chemical Shifts (ppm) & Functional Groups \\
\hline $0-45$ & $\begin{array}{l}\text { Alkyl-carbon; Linear alkane methyl group (14 ppm), Methylene } \\
\text { carbons and methyl groups in branched alkanes ( } 23 \mathrm{ppm}), \\
\text { Methylene carbons in branched alkanes, and methane carbons } \\
\text { (30 ppm), Methylene and quaternary carbons ( } 38 \mathrm{ppm})\end{array}$ \\
\hline $45-60$ & $\begin{array}{l}\text { Alkyl-carbon attached to } \mathrm{N} \text { and } \mathrm{O} \text { atoms; Quaternary carbons } \\
\qquad(47 \mathrm{ppm})\end{array}$ \\
\hline $60-110$ & $\begin{array}{l}\text { Alkyl-carbon attached to } \mathrm{O} \text { atoms derived from polysaccharide; } \\
\text { Alcohol groups }(65-72 \mathrm{ppm})\end{array}$ \\
\hline $110-140$ & $\begin{array}{l}\text { Aromatic and Alkene-carbons attached to hydrogen or carbon; } \\
\text { Terminal }=\mathrm{CH}_{2} \text { and protonated aromatic carbons of } \mathrm{O}-\text { and } \mathrm{N}- \\
\text { substituted aromatic compounds ( } 115 \mathrm{ppm}), \mathrm{CH}-\mathrm{CH}_{3} \text {, alkene } \\
\text { carbons conjugated with carboxylic acids and esters, protonated } \\
\text { aromatic carbons ( } 127 \text { ppm), Alkylbensenesulfonates and } \\
\text { alkylbenzenes (140 ppm) }\end{array}$ \\
\hline $140-160$ & $\begin{array}{c}\text { Aromatic and Alkene-carbons attached to oxygen; Alkyl, } \\
\text { methoxy, ester, and ketone substituted alkenes (140-155 ppm), } \\
\text { C1 carbon of phenols (155 ppm) }\end{array}$ \\
\hline $160-220$ & $\begin{array}{c}\text { Carbonyl carbons; Carboxylic, ketone, and amide C; Carboxylic } \\
\text { acids (170-190 ppm), Ketones (210 ppm) }\end{array}$ \\
\hline
\end{tabular}

* (Chefetz et al., 1998; Nanny and Ratasuk, 2002; Yabuta et al., 2008)

\section{$\underline{\text { Humic Acid Evolution (Production) and Characterization }}$}

The evolution (production) of HA has been an indicator of the extent of waste stabilization in landfills, composting, and wastewater sludge (Albrecht et al., 2011; Castaldi et al., 2005; Chefetz et al., 1998; Fukushima et al., 2009; Lguirati et al., 2005; Nanny and Ratasuk, 2002). The evolution of HA is evaluated by the extent of humification. Humification is traditionally used to determine the extent of the transformation of organic matter to humus (Hargitai, 1993). Traditional characterization techniques employed to determine the degree of waste humification during the aforementioned processes include UV-Vis absorption, solid-state NMR, and FTIR (Albrecht et al., 2011; Castaldi et al., 2005; Chefetz et al., 1998; Fukushima et al., 2009; Lguirati et al., 2005; Nanny and Ratasuk, 2002). Typical spectroscopic parameters that are used to determine the degree of humification are the ratios of the UV-Vis absorption at 
wavelengths of $465 \mathrm{~nm}\left(\mathrm{E}_{465}\right)$ and $665 \mathrm{~nm}\left(\mathrm{E}_{665}\right)$. During the evolution of $\mathrm{HA}$ the $\mathrm{E}_{465} / \mathrm{E}_{665}$ values decreased while the $\mathrm{E}_{665}$ values increased (Amir et al., 2003; Domeizel et al., 2004; Fukushima et al., 2009; Rivero et al., 2004).

The major spectral peaks of HA are summarized in Table 2-2. During the humification process the spectral peaks at $2980-2850 \mathrm{~cm}^{-1}$ decreased and also became broader as waste degradation progressed (Fukushima et al., 2009). Additional peaks that appeared during of the degradation process were reported at 1720 and $1230 \mathrm{~cm}^{-1}$ which are related to the carboxylic and phenolic hydroxyl groups, typical functional groups of HA (Stevenson, 1994).

Table 2-3. Major Functional Groups of Humic Acid*

\begin{tabular}{|c|c|c|}
\hline $\begin{array}{l}\text { Wavenumber } \\
\left(\mathrm{cm}^{-1}\right)\end{array}$ & Vibration & Functional Group \\
\hline $3500-3300$ & $\begin{array}{l}\text { O-H Stretch } \\
\text { N-H Stretch }\end{array}$ & $\begin{array}{l}\text { Phenolic, Alcoholic, or Carboxyl } \\
\text { Hydroxyl Group Amides and Amines }\end{array}$ \\
\hline $2980-2850$ & O-H Stretch & Aliphatic Chains \\
\hline 1720 & C-H Stretch & Carbonyl Group \\
\hline $1660-1640$ & $\mathrm{C}=\mathrm{O}$ Stretch & $\begin{array}{l}\text { Carbonyl Group, Quinones and/or } \\
\text { ketonic acids and primary amides }\end{array}$ \\
\hline $1550-1510$ & $\mathrm{C}=\mathrm{C}$ & Carbonyl Group \\
\hline $1480-1380$ & N-H Deformation & $\begin{array}{l}\text { Aromatic Amine or Amide } \\
\text { (Amide II-Band) }\end{array}$ \\
\hline $1460-1440$ & C-H Deformation & $\begin{array}{l}\text { Aliphatic } \mathrm{C}-\mathrm{H} \text { deformation of } \\
\text { structures such as fatty acids and } \\
\text { waxes }\end{array}$ \\
\hline $1400-1380$ & $\mathrm{O}-\mathrm{H}, \mathrm{C}=\mathrm{C}$ Stretches & Phenols and Aliphatics \\
\hline $1280-1220$ & N-H Deformation & $\begin{array}{c}\text { Aromatic Amine or Amide } \\
\text { (Amide II-Band) }\end{array}$ \\
\hline $1150-1050$ & C-O-H Deformation, C-O Stretching & $\begin{array}{c}\text { Carboxylic and Phenol, Alcohol and } \\
\text { Ether }\end{array}$ \\
\hline $1080-1030$ & C-O-C Stretches & Carbohydrates \\
\hline
\end{tabular}

* (Fukushima et al., 2009); Stevenson and Goh (1971); Fukushima et al. (2009); Senesi and Brunetti (1996) 


\section{$\underline{\text { Summary }}$}

Understanding the requirements to achieve sustainable landfilling of MSW by removing recalcitrant organics and ammonia-nitrogen will provide the opportunity for landfills to reach functional stability. Currently the ability of a landfill to reach functional stability is still unknown and requires further investigation including defining the technological and economic requirements.

Despite the applicability of the aforementioned technique to characterize MSW there is still a need for further studies on the applicability of these techniques for landfilled MSW due to the extreme heterogeneity and limited knowledge of initial waste composition. The challenge of characterizing solid waste using traditional chemical, biological, and physical parameters is the fact that these techniques do not provide a comprehensive data set to fully understand the point at which waste is completely degraded and the landfill has reached functional stability is not yet clearly defined (Kelly et al., 2006). Understanding waste degradation at the molecular level can provide more detailed information to assess why the waste is stabilized and determine the mechanisms that might be responsible for the waste to achieve acceptable final storage quality.

One shortcoming of spectroscopic techniques is that each sample will only reflect the stage of waste degradation at the time of sampling. Despite the advances in the information regarding FTIR analysis of MSW there is still a need to discover the specific spectral band shifts during the degradation process. This leads to the knowledge gap in understanding the complete waste degradation process. In this study the waste degradation process will be characterized prior to waste degradation, during, and at the completion of waste degradation. These data will significantly add to the existing knowledge of waste stabilization and acceptable final storage quality of solid waste when correlating the spectra data to traditional characterization techniques. 
This will permit the ability to make specific recommendations on the end point for completion of waste treatment based on the changes in the functional groups based on reactivity, solubility, and composition. 


\section{$\underline{\text { References }}$}

Ahmed, F. N., \& Lan, C. Q. (2012). Treatment of landfill leachate using membrane bioreactors: A review. Desalination, 287(0), 41-54. doi: http://dx.doi.org/10.1016/j.desal.2011.12.012

Alaton, I. A., Balcioglu, I. A., \& Bahnemann, D. W. (2002). Advanced oxidation of a reactive dyebath effluent: comparison of $\mathrm{O} 3, \mathrm{H} 2 \mathrm{O} 2 / \mathrm{UV}-\mathrm{C}$ and $\mathrm{TiO} 2 / \mathrm{UV}-\mathrm{A}$ processes. Water Research, 36(5), 1143-1154. doi: http://dx.doi.org/10.1016/S0043-1354(01)00335-9

Albrecht, R., Le Petit, J., Terrom, G., \& Périssol, C. (2011). Comparison between UV spectroscopy and nirs to assess humification process during sewage sludge and green wastes co-composting. Bioresource Technology, 102(6), 4495-4500. doi: http://dx.doi.org/10.1016/j.biortech.2010.12.053

Amir, S., Hafidi, M., Bailly, J.-R., \& Revel, J.-C. (2003). Characterization of humic acids extracted from sewage sludge during composting and of their Sephadex ${ }^{\circledR}$ gel fractions. Agronomie, 23(3), 269-275.

Amir, S., Jouraiphy, A., Meddich, A., El Gharous, M., Winterton, P., \& Hafidi, M. (2010). Structural study of humic acids during composting of activated sludge-green waste: Elemental analysis, FTIR and 13C NMR. Journal of Hazardous Materials, 177(1-3), 524-529. doi: http://dx.doi.org/10.1016/j.jhazmat.2009.12.064

Amokrane, A., Comel, C., \& Veron, J. (1997). Landfill leachates pretreatment by coagulationflocculation. Water Research, 31(11), 2775-2782. doi: http://dx.doi.org/10.1016/S00431354(97)00147-4

Baccini, P. (1989). The landfill : reactor and final storage: Swiss Workshop on Land Disposal of Solid Wastes, Gerzensee, March 14-17, 1988: Berlin ; New York : Springer-Verlag, c1989.

Bae, J.-H., Kim, S.-K., \& Chang, H.-S. (1997). Treatment of landfill leachates: Ammonia removal via nitrification and denitrification and further COD reduction via Fenton's treatment followed by activated sludge. Water Science and Technology, 36(12), 341-348. doi: http://dx.doi.org/10.1016/S0273-1223(97)00736-1

Baldock, J. A., \& Skjemstad, J. O. (2000). Role of the soil matrix and minerals in protecting natural organic materials against biological attack. Organic Geochemistry, 31(7-8), 697710. doi: http://dx.doi.org/10.1016/S0146-6380(00)00049-8

Barber, C., \& Maris, P. J. (1984). Recirculation of leachate as a landfill management option: benefits and operational problems. Quarterly Journal of Engineering Geology and Hydrogeology, 17(1), 19-29. doi: 10.1144/gsl.qjeg.1984.017.01.05

Barlaz, M. A. (2006). Forest products decomposition in municipal solid waste landfills. Waste Management, 26, 321-333. doi: 10.1016/j.wasman.2005.11.002

Barlaz, M. A., Ham, R. K., Schaefer, D. M., \& Isaacson, R. (1990). Methane production from municipal refuse: A review of enhancement techniques and microbial dynamics. Critical Reviews in Environmental Control, 19(6), 557-584. doi: 10.1080/10643389009388384

Barlaz, M. A., Rooker, A. P., Kjeldsen, P., Gabr, M. A., \& Borden, R. C. (2002). Critical Evaluation of Factors Required To Terminate the Postclosure Monitoring Period at Solid Waste Landfills. Environmental Science \& Technology, 36(16), 3457-3464. doi: 10.1021/es011245u

Batarseh, Reinhart, D., \& Daly, L. (2007). Liquid Sodium Ferrate and Fenton's Reagent for Treatment of Mature Landfill Leachate. Journal of Environmental Engineering, 133(11), 1042-1050. doi: doi:10.1061/(ASCE)0733-9372(2007)133:11(1042) 
Batarseh, E. S., Reinhart, D. R., \& Berge, N. D. (2010). Sustainable disposal of municipal solid waste: Post bioreactor landfill polishing. Waste Management, 30(11), 2170-2176. doi: http://dx.doi.org/10.1016/j.wasman.2010.06.015

Baun, A., Ledin, A., Reitzel, L. A., Bjerg, P. L., \& Christensen, T. H. (2004). Xenobiotic organic compounds in leachates from ten Danish MSW landfills - chemical analysis and toxicity tests. Water Research, 38(18), 3845-3858. doi: http://dx.doi.org/10.1016/j.watres.2004.07.006

Baun, D. L., \& Christensen, T. H. (2004). Speciation of Heavy Metals in Landfill Leachate: A Review. Waste Management \& Research, 22(1), 3-23. doi: 10.1177/0734242x04042146

Belevi, H., \& Baccini, P. (1989). Long-Term Behavior of Municipal Solid Waste Landfills. Waste Management \& Research, 7(1), 43-56. doi: 10.1177/0734242x8900700106

Beltrán, F., González, M., Ribas, F., \& Alvarez, P. (1998). Fenton Reagent Advanced Oxidation of Polynuclear Aromatic Hydrocarbons in Water. Water, Air, and Soil Pollution, 105(34), 685-700. doi: 10.1023/A:1005048206991

Benitez, F. J., Beltran-Heredia, J., Acero, J. L., \& Rubio, F. J. (2001). Oxidation of several chlorophenolic derivatives by UV irradiation and hydroxyl radicals. Journal of Chemical Technology \& Biotechnology, 76(3), 312-320. doi: 10.1002/jctb.384

Berge, N. D., Reinhart, D. R., \& Batarseh, E. S. (2009). An assessment of bioreactor landfill costs and benefits. Waste Management, 29(5), 1558-1567. doi: http://dx.doi.org/10.1016/j.wasman.2008.12.010

Berge, N. D., Reinhart, D. R., Dietz, J., \& Townsend, T. (2006). In situ ammonia removal in bioreactor landfill leachate. Waste Management, 26(4), 334-343. doi: http://dx.doi.org/10.1016/j.wasman.2005.11.003

Berge, N. D., Reinhart, D. R., Dietz, J. D., \& Townsend, T. (2007). The impact of temperature and gas-phase oxygen on kinetics of in situ ammonia removal in bioreactor landfill leachate. Water Research, 41(9), 1907-1914. doi: http://dx.doi.org/10.1016/j.watres.2007.01.049

Bilstad, T., \& Madland, M. V. Leachate Minimization by Reverse-Osmosis.

Bohdziewicz, J., Neczaj, E., \& Kwarciak, A. (2008). Landfill leachate treatment by means of anaerobic membrane bioreactor. Desalination, 221(1-3), 559-565. doi: http://dx.doi.org/10.1016/j.desal.2007.01.117

Bott, C. B., \& Parker, D. S. (2011). WEF/WERF Study Quantifying Nutrient Removal Technology Performance.

Bu, L., Wang, K., Zhao, Q.-L., Wei, L.-L., Zhang, J., \& Yang, J.-C. (2010). Characterization of dissolved organic matter during landfill leachate treatment by sequencing batch reactor, aeration corrosive cell-Fenton, and granular activated carbon in series. Journal of Hazardous Materials, 179(1-3), 1096-1105. doi: http://dx.doi.org/10.1016/j.jhazmat.2010.03.118

Burton, S. A. Q., \& Watson-Craik, I. A. (1998). Ammonia and nitrogen fluxes in landfill sites: applicability to sustainable landfilling. Waste Management \& Research, 16(1), 41-53. doi: $10.1177 / 0734242 \times 9801600106$

Calace, N., Liberatori, A., Petronio, B. M., \& Pietroletti, M. (2001). Characteristics of different molecular weight fractions of organic matter in landfill leachate and their role in soil sorption of heavy metals. Environmental Pollution, 113(3), 331-339. doi: http://dx.doi.org/10.1016/S0269-7491(00)00186-X 
Caricasole, P., Provenzano, M. R., Hatcher, P. G., \& Senesi, N. (2011). Evolution of organic matter during composting of different organic wastes assessed by CPMAS 13C NMR spectroscopy. Waste Management, 31(3), 411-415. doi: http://dx.doi.org/10.1016/j.wasman.2010.09.020

Castaldi, P., Alberti, G., Merella, R., \& Melis, P. (2005). Study of the organic matter evolution during municipal solid waste composting aimed at identifying suitable parameters for the evaluation of compost maturity. Waste Management, 25(2), 209-213. doi: http://dx.doi.org/10.1016/j.wasman.2004.12.011

Cecen, F., \& Cakiroglu, D. (2001). Impact of landfill leachate on the co-treatment of domestic wastewater. Biotechnology Letters (9), 821.

Chefetz, B., Hader, Y., \& Chen, Y. (1998). Dissolved Organic Carbon Fractions Formed during Composting of Municipal Solid Waste: Properties and Significance. Acta hydrochimica et hydrobiologica, 26(3), 172-179. doi: 10.1002/(SICI)1521401X(199805) 26:3<172::AID-AHEH172>3.0.CO;2-5

Chen, H.-Y., Chen, L.-D., Chiang, Z.-Y., Hung, C.-C., Lin, F.-J., Chou, W.-C., . . Wen, L.-S. (2010). Size fractionation and molecular composition of water-soluble inorganic and organic nitrogen in aerosols of a coastal environment. Journal of Geophysical Research: Atmospheres, 115(D22), n/a-n/a. doi: 10.1029/2010JD014157

Christensen, J. B., Jensen, D. L., \& Christensen, T. H. (1996). Effect of dissolved organic carbon on the mobility of cadmium, nickel and zinc in leachate polluted groundwater. Water Research, 30(12), 3037-3049. doi: http://dx.doi.org/10.1016/S0043-1354(96)00091-7

Christensen, T. H., Cossu, R., \& Stegmann, R. (1992). Landfilling of waste : leachate: London ; New York : Elsevier Applied Science, c1992.

Chugh, S., Clarke, W., Pullammanappallil, P., \& Rudolph, V. (1998). Effect of recirculated leachate volume on MSW degradation. Waste Management \& Research, 16(6), 564-573. doi: 10.1177/0734242x9801600607

Cossu, R., Raga, R., \& Rossetti, D. (2003). The PAF model: an integrated approach for landfill sustainability. Waste Management, 23(1), 37-44. doi: http://dx.doi.org/10.1016/S0956$\underline{053 X(02) 00147-2}$

Cuetos, M. J., Gómez, X., Otero, M., \& Morán, A. (2010). Anaerobic digestion and co-digestion of slaughterhouse waste (SHW): Influence of heat and pressure pre-treatment in biogas yield. Waste Management, 30(10), 1780-1789. doi: http://dx.doi.org/10.1016/j.wasman.2010.01.034

Deng, Y., \& Englehardt, J. D. (2006). Treatment of landfill leachate by the Fenton process. Water Research, 40(20), 3683-3694. doi: http://dx.doi.org/10.1016/j.watres.2006.08.009

DeWalle, F. B., \& Chian, E. S. K. (1974). Removal of Organic Matter by Activated Carbon Columns. Journal of the Environmental Engineering Division, 100(EE5), 1089.

Döberl, G., Huber, R., \& Brunner, P. H. (2005). Long-term emissions from landfills - is "Final Storage Quality" within reach? Paper presented at the Sardinia Symposium, Sardinia, Italy.

Doedens, H., \& Cord-Landwehr, K. (1989). Leachate Recirculation. In T. H. Christensen, R. Stegmann \& R. Cossu (Eds.), Sanitary landfilling : process, technology and environmental impact: London, England; San Diego, CA : Academic Press, c1989.

Domeizel, M., Khalil, A., \& Prudent, P. (2004). UV spectroscopy: a tool for monitoring humification and for proposing an index of the maturity of compost. Bioresource Technology, 94(2), 177-184. doi: http://dx.doi.org/10.1016/j.biortech.2003.11.026 
Ehrig, H.-J., \& Krümpelbeck, I. (2001). The emission behaviour of old landfills in the aftercare phase. Paper presented at the Sardinia Symposium, Sardinia, Italy.

El-Fadel, M. (1999). Leachate Recirculation Effects on Settlement and Biodegradation Rates in MSW Landfills. Environmental Technology, 20(2), 121-133. doi: 10.1080/09593332008616802

El Hajjouji, H., Ait Baddi, G., Yaacoubi, A., Hamdi, H., Winterton, P., Revel, J. C., \& Hafidi, M. (2008). Optimisation of biodegradation conditions for the treatment of olive mill wastewater. Bioresource Technology, 99(13), 5505-5510. doi: http://dx.doi.org/10.1016/j.biortech.2007.11.005

Englehardt, J., Deng, Y., Meeroff, D., Legrenzi, Y., Mognol, J., \& Polar, J. (2006). Options for Managing Municipal Landfill Leachate: Year 1: Development of Iron-Mediated Treatment Processes. Florida Center for Solid and Hazardous Waste Management.

Erses, A. S., Onay, T. T., \& Yenigun, O. (2008). Comparison of aerobic and anaerobic degradation of municipal solid waste in bioreactor landfills. Bioresource Technology, 99(13), 5418-5426. doi: http://dx.doi.org/10.1016/j.biortech.2007.11.008

European Commission. (1999). Handbook for the Implementation of EC Environmental Legislation.

Faix, O. (1991). Classification of Lignins from Different Botanical Origins by FT-IR Spectroscopy Holzforschung - International Journal of the Biology, Chemistry, Physics and Technology of Wood (Vol. 45, pp. 21).

Fukushima, A., Kusano, M., Redestig, H., Arita, M., \& Saito, K. (2009). Integrated omics approaches in plant systems biology. Current Opinion in Chemical Biology, 13(5-6), 532-538. doi: http://dx.doi.org/10.1016/j.cbpa.2009.09.022

Ghanbarzadeh Lak, M., Sabour, M. R., Amiri, A., \& Rabbani, O. (2012). Application of quadratic regression model for Fenton treatment of municipal landfill leachate. Waste Management, 32(10), 1895-1902. doi: http://dx.doi.org/10.1016/j.wasman.2012.05.020

Giannis, A., Makripodis, G., Simantiraki, F., Somara, M., \& Gidarakos, E. (2008). Monitoring operational and leachate characteristics of an aerobic simulated landfill bioreactor. Waste Management, 28(8), 1346-1354. doi: http://dx.doi.org/10.1016/j.wasman.2007.06.024

Goi, A., Veressinina, Y., \& Trapido, M. (2010). Fenton Process for Landfill Leachate Treatment: Evaluation of Biodegradability and Toxicity. Journal of Environmental Engineering, 136(1), 46-53. doi: doi:10.1061/(ASCE)EE.1943-7870.0000132

González-Vila, F. J., Almendros, G., \& Madrid, F. (1999). Molecular alterations of organic fractions from urban waste in the course of composting and their further transformation in amended soil. Science of The Total Environment, 236(1-3), 215-229. doi: http://dx.doi.org/10.1016/S0048-9697(99)00284-3

Gonzalez, L., Bernabe, M., Felix Espinosa, J., Tejero-Mateo, P., Gil-Serrano, A., Mantegazza, N., . . Jimenez-Barbero, J. (1999). Solvent-dependent conformational behaviour of lipochitoligosaccharides related to Nod factors. Carbohydrate Research, 318(1-4), 10-19. doi: http://dx.doi.org/10.1016/S0008-6215(99)00082-8

Green, L. C., \& Hudgins, M. P. (2000). Innovative Landfill Gas Control Using and Aerobic Landfill System. Paper presented at the 1st International Conference on Solid Waste, Rome, Italy.

Grube, M., Zagreba, E., Gromozova, E., \& Fomina, M. (1999). Comparative investigation of the macromolecular composition of mycelia forms Thielavia terrestris by infrared 
spectroscopy. Vibrational Spectroscopy, 19(2), 301-306. doi:

http://dx.doi.org/10.1016/S0924-2031(98)00074-5

Guzzella, L., Feretti, D., \& Monarca, S. (2002). Advanced oxidation and adsorption technologies for organic micropollutant removal from lake water used as drinking-water supply. Water Research, 36(17), 4307-4318. doi: http://dx.doi.org/10.1016/S0043-1354(02)00145-8

Hafidi, M., Amir, S., \& Revel, J.-C. (2005). Structural characterization of olive mill waster-water after aerobic digestion using elemental analysis, FTIR and 13C NMR. Process Biochemistry, 40(8), 2615-2622. doi: http://dx.doi.org/10.1016/j.procbio.2004.06.062

Hao, Y.-J., Chen, Y.-X., Wu, W.-X., Zhang, S.-G., Liu, H.-Q., \& Ji, M. (2009). The pathway of in-situ ammonium removal from aerated municipal solid waste bioreactor: nitrification/denitrification or air stripping? Waste Management \& Research. doi: $10.1177 / 0734242 \times 09355182$

Hargitai, L. (1993). The role of organic matter content and humus quality in the maintenance of soil fertility and in environmental protection. Landscape and Urban Planning, 27(2-4), 161-167. doi: http://dx.doi.org/10.1016/0169-2046(93)90044-E

Hater, G. R., Young, K. E., Simpson, C., \& Harris, J. M. (2001). Economics of Eight Scenarios for Landfill Bioreactors as Compared to a Base Case Subtitle D Landfill. Paper presented at the Waste Tech 2001, San Diego, CA.

He, J.-z., Shen, J.-p., Zhang, L.-m., Zhu, Y.-g., Zheng, Y.-m., Xu, M.-g., \& Di, H. (2007). Quantitative analyses of the abundance and composition of ammonia-oxidizing bacteria and ammonia-oxidizing archaea of a Chinese upland red soil under long-term fertilization practices. Environmental Microbiology, 9(9), 2364-2374. doi: 10.1111/j.14622920.2007.01358.x

He, X., Xi, B., Wei, Z., Guo, X., Li, M., An, D., \& Liu, H. (2011). Spectroscopic characterization of water extractable organic matter during composting of municipal solid waste. Chemosphere, 82(4), 541-548. doi: http://dx.doi.org/10.1016/j.chemosphere.2010.10.057

Hesse, M., Meier, H., \& Zeeh, B. (2005). Spektroskopische Methoden in der organischen Chemie : 102 Tabellen: Thieme, Universitäts- und Landesbibliothek, 2005.

Heyer, K. U., Hupe, K., Ritzkowski, M., \& Stegmann, R. (2005). Pollutant release and pollutant reduction - Impact of the aeration of landfills. Waste Management, 25(4), 353-359. doi: http://dx.doi.org/10.1016/j.wasman.2005.02.007

Hjelmar, O., \& van der Sloot, H. (2003). The EU landfill directive and the council decision on acceptance criteria for waste to be landfilled: overview and associated $R \& D$ needs. Paper presented at the Sardinia Symposium, Sardinia, Italy.

Höfl, C., Sigl, G., Specht, O., Wurdack, I., \& Wabner, D. (1997). Oxidative degradation of aox and cod by different advanced oxidation processes: A comparative study with two samples of a pharmaceutical wastewater. Water Science and Technology, 35(4), 257-264. doi: http://dx.doi.org/10.1016/S0273-1223(97)00033-4

Hudgins, M., \& March, J. (1998). In situ Municipal Solid Waste Composting Using an Aerobic Landfill System (pp. 144-157). American Technologies Inc.

IWML-WG. (1999). The Role and Operation of the Flushing Bioreactor.

Jacobsen, N. E. (2007). NMR spectroscopy explained : simplified theory, applications and examples for organic chemistry and structural biology: Hoboken, N.J. : WileyInterscience, c2007. 
Kang, K.-H., Shin, H. S., \& Park, H. (2002). Characterization of humic substances present in landfill leachates with different landfill ages and its implications. Water Research, 36(16), 4023-4032. doi: http://dx.doi.org/10.1016/S0043-1354(02)00114-8

Karnik, M., \& Parry, C. (1997). Cost implication of operating landfills as flushing bioreactors. Paper presented at the Sardinia Symposium, Sardinia, Italy.

Katsumata, H., Sada, M., Kaneco, S., Suzuki, T., Ohta, K., \& Yobiko, Y. (2008). Humic acid degradation in aqueous solution by the photo-Fenton process. Chemical Engineering Journal, 137(2), 225-230. doi: http://dx.doi.org/10.1016/j.cej.2007.04.019

Khire, M. V., \& Mukherjee, M. (2007). Leachate injection using vertical wells in bioreactor landfills. Waste Management, 27(9), 1233-1247. doi: http://dx.doi.org/10.1016/j.wasman.2006.07.010

Kinman, R. N., Nutini, D. L., Walsh, J. J., Vogt, W. G., Stamm, J., \& Rickabaugh, J. (1987). Gas enhancement techniques in landfill simulators. Waste Management \& Research, 5(1), 1325. doi: http://dx.doi.org/10.1016/0734-242X(87)90031-0

Kjeldsen, P., Barlaz, M. A., Rooker, A. P., Baun, A., Ledin, A., \& Christensen, T. H. (2002). Present and Long-Term Composition of MSW Landfill Leachate: A Review. Critical Reviews in Environmental Science and Technology, 32(4), 297-336. doi: 10.1080/10643380290813462

Kurniawan, T. A., Lo, W., Chan, G., \& Sillanpaa, M. E. T. (2010). Biological processes for treatment of landfill leachate. Journal of Environmental Monitoring, 12(11), 2032-2047. doi: 10.1039/C0EM00076K

Lguirati, A., Ait Baddi, G., El Mousadik, A., Gilard, V., Revel, J. C., \& Hafidi, M. (2005). Analysis of humic acids from aerated and non-aerated urban landfill composts. International Biodeterioration \& Biodegradation, 56(1), 8-16. doi: http://dx.doi.org/10.1016/j.ibiod.2005.03.004

Linde, K., Jönsson, A.-s., \& Wimmerstedt, R. (1995). Treatment of three types of landfill leachate with reverse osmosis. Desalination, 101(1), 21-30. doi: http://dx.doi.org/10.1016/0011-9164(95)00004-L

Lorenz, C., Windler, L., von Goetz, N., Lehmann, R., Schuppler, M., Hungerbuhler, K., . . Nowack, B. (2012). Characterization of silver release from commercially available functional (nano) textiles. Chemosphere, 89, 817 - 824.

Lu, J. C. S., Eichenberger, B., \& Stearns, R. J. (1985). Leachate from Municipal Landfills, Production And Management: Noyes Publications, Park Ridge, NJ.

Madejová, J. (2003). FTIR techniques in clay mineral studies. Vibrational Spectroscopy, 31(1), 1-10. doi: http://dx.doi.org/10.1016/S0924-2031(02)00065-6

Marañón, E., Castrillón, L., Fernández-Nava, Y., Fernández-Méndez, A., \& Fernández-Sánchez, A. (2008). Coagulation-flocculation as a pretreatment process at a landfill leachate nitrification-denitrification plant. Journal of Hazardous Materials, 156(1-3), 538-544. doi: http://dx.doi.org/10.1016/j.jhazmat.2007.12.084

Maximova, A., \& Koumanova, B. (2006). STUDY ON THE CONTENT OF CHEMICALS IN LANDFILL LEACHATE. In L. Simeonov \& E. Chirila (Eds.), Chemicals as Intentional and Accidental Global Environmental Threats (pp. 345-356): Springer Netherlands.

Morris, J. W. F., \& Barlaz, M. A. (2011). A performance-based system for the long-term management of municipal waste landfills. Waste Management, 31(4), 649-662. doi: http://dx.doi.org/10.1016/j.wasman.2010.11.018 
Nanny, M. A., \& Ratasuk, N. (2002). Characterization and comparison of hydrophobic neutral and hydrophobic acid dissolved organic carbon isolated from three municipal landfill leachates. Water Research, 36(6), 1572-1584. doi: http://dx.doi.org/10.1016/S00431354(01)00359-1

Naumann, D., Schultz, C. P., \& Helm, D. (1996). What can infrared spectroscopy tell us about the structure and composition of intact bacterial cells? : 1996.

Onay, T. T., \& Pohland, F. G. (1998). In situ nitrogen management in controlled bioreactor landfills. Water Research, 32(5), 1383-1392. doi: http://dx.doi.org/10.1016/S00431354(97)00392-8

Ouatmane, A., Provenzano, M. R., Hafidi, M., \& Senesi, N. (2000). Compost Maturity Assessment Using Calorimetry, Spectroscopy and Chemical Analysis. Compost Science \& Utilization, 8(2), 124-134. doi: 10.1080/1065657X.2000.10701758

Owen, W. F., Stuckey, D. C., Healy Jr, J. B., Young, L. Y., \& McCarty, P. L. (1979). Bioassay for monitoring biochemical methane potential and anaerobic toxicity. Water Research, 13(6), 485-492. doi: http://dx.doi.org/10.1016/0043-1354(79)90043-5

Pacey, J., Augenstein, D., Morck, R., Reinhart, D., \& Yazdani, R. (1999). The bioreactor landfill-An innovation in solid waste management. Paper presented at the MSW Management, SWANA, Silver Springs, Md.

Pehlivanoglu-Mantas, E., \& Sedlak, D. L. (2008). Measurement of dissolved organic nitrogen forms in wastewater effluents: Concentrations, size distribution and NDMA formation potential. Water Research, 42(14), 3890-3898. doi: 10.1016/j.watres.2008.05.017

Pérez, M., Torrades, F., Domènech, X., \& Peral, J. (2002). Fenton and photo-Fenton oxidation of textile effluents. Water Research, 36(11), 2703-2710. doi: http://dx.doi.org/10.1016/S0043-1354(01)00506-1

Piccolo, A., Zaccheo, P., \& Genevini, P. G. (1992). Chemical characterization of humic substances extracted from organic-waste-amended soils. Bioresource Technology, 40(3), 275-282. doi: http://dx.doi.org/10.1016/0960-8524(92)90154-P

Pohland, F. G. (1975). Sanitary landfill stabilization with leachate recycle and residual treatment. U.S. EPA, National Environmental Research Center, Cincinnati.

Prantl, R., Tesar, M., Huber-Humer, M., \& Lechner, P. (2006). Changes in carbon and nitrogen pool during in-situ aeration of old landfills under varying conditions. Waste Management, 26(4), 373-380. doi: http://dx.doi.org/10.1016/j.wasman.2005.11.010

Price, G. A., Barlaz, M. A., \& Hater, G. R. (2003). Nitrogen management in bioreactor landfills. Waste Management, 23(7), 675-688. doi: http://dx.doi.org/10.1016/S0956053X(03)00104-1

Primo, O., Rivero, M. J., \& Ortiz, I. (2008). Photo-Fenton process as an efficient alternative to the treatment of landfill leachates. Journal of Hazardous Materials, 153(1-2), 834-842. doi: http://dx.doi.org/10.1016/j.jhazmat.2007.09.053

Qasim, S. R., \& Chiang, W. (1994). Sanitary landfill leachate : generation, control, and treatment: Lancaster, Pa. : Technomic Pub. Co., c1994.

Raga, R., \& R., C. (2011). Full Scale Application of In Situ Aerobic Stabilization of Old Landfills. Paper presented at the Saradinia Symposium, Sardinia, Italy.

Read, A. D., Hudgins, M., \& Phillips, P. (2001). Perpetual landfilling through aeration of the waste mass; lessons from test cells in Georgia (USA). Waste Management, 21(7), 617629. doi: http://dx.doi.org/10.1016/S0956-053X(00)00124-0 
Reinhart, D. R. (1989). Fate of selected organic pollutants during landfill codisposal with municipal refuse: Georgia Institute of Technology, 1989-05.

Reinhart, D. R., \& Al-Yousfi, B. A. (1996). THE IMPACT OF LEACHATE RECIRCULATION ON MUNICIPAL SOLID WASTE LANDFILL OPERATING CHARACTERISTICS. Waste Management \& Research, 14(4), 337-346. doi: http://dx.doi.org/10.1006/wmre.1996.0035

Reinhart, D. R., Dietz, J. D., Tunnell, L. G., \& Christodoulou, A. (1994). Landfill leachate treatment for biological nutrient removal from wastewater. International Journal of Environment and Pollution, 4(1), 97-106. doi: 10.1504/IJEP.1994.028350

Reinhart, D. R., McCreanor, P. T., \& Townsend, T. (2002). The bioreactor landfill: Its status and future. Waste Management \& Research, 20(2), 172-186. doi: 10.1177/0734242x0202000209

Reinhart, D. R., \& Townsend, T. G. (1998). Landfill bioreactor design and operation: Boca Raton, Fla : Lewis Publishers, c1998.

Renou, S., Givaudan, J. G., Poulain, S., Dirassouyan, F., \& Moulin, P. (2008). Landfill leachate treatment: Review and opportunity. Journal of Hazardous Materials, 150(3), 468-493. doi: http://dx.doi.org/10.1016/j.jhazmat.2007.09.077

Rivas, F. J., Beltrán, F. J., Gimeno, O., \& Alvarez, P. (2003). Treatment of brines by combined Fenton's reagent-aerobic biodegradation: II. Process modelling. Journal of Hazardous Materials, 96(2-3), 259-276. doi: http://dx.doi.org/10.1016/S0304-3894(02)00216-9

Rivero, C., Chirenje, T., Ma, L. Q., \& Martinez, G. (2004). Influence of compost on soil organic matter quality under tropical conditions. Geoderma, 123(3-4), 355-361. doi: http://dx.doi.org/10.1016/j.geoderma.2004.03.002

Robinson, H., Carbille, M., Harris, G., Steward, R., \& Robinson, T. (2013, October 3, 2013). Incorporation of ultrafiltration membranes into aerobic biological treatment of landfill leachates. Paper presented at the Fourteenth International Waste Management and Landfill Symposium, Sardinia, Italy.

Rodriguez, J., Parra, C., Contreras, D., Freer, J., \& Baeza, J. (2001). Dihydroxybenzenes: Driven Fenton reactions. Water Science and Technology, 44(5), 251-256.

Šan, I., \& Onay, T. T. (2001). Impact of various leachate recirculation regimes on municipal solid waste degradation. Journal of Hazardous Materials, 87(1-3), 259-271. doi: http://dx.doi.org/10.1016/S0304-3894(01)00290-4

Sarria, V., Parra, S., Invernizzi, M., Peringer, P., \& Pulgarin, C. (2001). Photochemicalbiological treatment of a real industrial biorecalcitrant wastewater containing 5-amino-6methyl-2-benzimidazolone. Water Science and Technology, 44(5), 93-101.

Scharff, H. (2010a). Landfill Closure, Aftercare and Final Use Solid Waste Technology \& Management (pp. 932-947): John Wiley \& Sons, Ltd.

Scharff, H. (2010b). Landfill sustainability and aftercare completion criteria. Paper presented at the 1st International Conference on Final Sinks, Vienna, Austria.

Sen, B., \& Chandra, T. S. (2007). Chemolytic and solid-state spectroscopic evaluation of organic matter transformation during vermicomposting of sugar industry wastes. Bioresource Technology, 98(8), 1680-1683. doi: http://dx.doi.org/10.1016/j.biortech.2006.06.007

Senesi, N., \& Brunetti, G. (1996). Chemical and Physico-Chemical Parameters for Quality Evaluation of Humic Substances Produced during Composting. In M. de Bertoldi, P. Sequi, B. Lemmes \& T. Papi (Eds.), The Science of Composting (pp. 195-212): Springer Netherlands. 
Singh, S. K., \& Tang, W. Z. (2013). Statistical analysis of optimum Fenton oxidation conditions for landfill leachate treatment. Waste Management, 33(1), 81-88. doi: http://dx.doi.org/10.1016/j.wasman.2012.08.005

Smidt, E., Bohm, K., \& Schwanniner, M. (2011). The Application of FT-IR Spectroscopy in Waste Management. In G. Nikolic (Ed.), New Analytical Approaches and FTIR Strategies.

Smidt, E., Eckhardt, K.-u., Lechner, P., Schulten, H.-r., \& Leinweber, P. (2005). Characterization of different decomposition stages of biowaste using FT-IR spectroscopy and pyrolysis-field ionization mass spectrometry. Biodegradation, 16(1), 67-79. doi: 10.1007/s10531-004-0430-8

Smidt, E., Lechner, P., Schwanninger, M., Haberhauer, G., \& Gerzabek, M. H. (2002). Characterization of Waste Organic Matter by FT-IR Spectroscopy: Application in Waste Science. Applied Spectroscopy, 56(9), 1170-1175.

Smith, B. C. (1999). Infrared spectral interpretation : a systematic approach: Boca Raton : CRC Press, c1999.

Socrates, G. (2007). Infrared and Raman Characteristic Group Frequencies: Tables and Charts: West Sussex: John Wiley \& Sons.

Stessel, R. I., \& Murphy, R. J. (1992). A lysimeter study of the aerobic landfill concept. Waste Management \& Research, 10(6), 485-503. doi: http://dx.doi.org/10.1016/0734242X(92)90089-4

Stevenson, F. J. (1994). Humus Chemistry: Genesis, Composition, Reactions (2nd ed.): Wiley, New York.

Stevenson, F. J., \& Goh, K. M. (1971). Infrared spectra of humic acids and related substances. Geochimica et Cosmochimica Acta, 35(5), 471-483. doi: http://dx.doi.org/10.1016/00167037(71)90044-5

Syzdek, A. C., \& Ahlert, R. C. (1984). Separation of landfill leachate with polymeric ultrafiltration membranes. Journal of Hazardous Materials, 9(2), 209-220. doi: http://dx.doi.org/10.1016/0304-3894(84)80018-7

Tabet, K., Moulin, P., Vilomet, J. D., Amberto, A., \& Charbit, F. (2002). Purification of landfill leachate with membrane processes: preliminary studies for an industrial plant. Separation Science and Technology, 37(5), 1041-1063. doi: 10.1081/SS-120002240

Tatsi, A. A., Zouboulis, A. I., Matis, K. A., \& Samaras, P. (2003). Coagulation-flocculation pretreatment of sanitary landfill leachates. Chemosphere, 53(7), 737-744. doi: http://dx.doi.org/10.1016/S0045-6535(03)00513-7

Tchobanoglous, G., \& Kreith, F. (2002). Handbook of solid waste management McGraw-Hill's AccessEngineering (pp. 1 online resource). Retrieved from http://www.loc.gov/catdir/toc/mh031/2002021284.html

http://www.loc.gov/catdir/bios/mh041/2002021284.html

http://accessengineeringlibrary.com/browse/handbook-of-solid-waste-management-secondedition

Tekin, H., Bilkay, O., Ataberk, S. S., Balta, T. H., Ceribasi, I. H., Sanin, F. D., . . Yetis, U. (2006). Use of Fenton oxidation to improve the biodegradability of a pharmaceutical wastewater. Journal of Hazardous Materials, 136(2), 258-265. doi: http://dx.doi.org/10.1016/j.jhazmat.2005.12.012 
Tittlebaum, M. E. (1982). Organic Carbon Content Stabilization through Landfill Leachate Recirculation. Journal (Water Pollution Control Federation), 54(5), 428-433. doi: $10.2307 / 25041341$

Townsend, T., Miller, W., Lee, H., \& Earle, J. (1996). Acceleration of Landfill Stabilization Using Leachate Recycle. Journal of Environmental Engineering, 122(4), 263-268. doi: doi:10.1061/(ASCE)0733-9372(1996)122:4(263)

Tseng, D. Y., Vir, R., Traina, S. J., \& Chalmers, J. J. (1996). A Fourier-transform infrared spectroscopic analysis of organic matter degradation in a bench-scale solid substrate fermentation (composting) system. Biotechnology and Bioengineering, 52(6), 661-671. doi: 10.1002/(SICI)1097-0290(19961220)52:6<661::AID-BIT4>3.0.CO;2-M

Umar, M., Aziz, H. A., \& Yusoff, M. S. (2010). Trends in the use of Fenton, electro-Fenton and photo-Fenton for the treatment of landfill leachate. Waste Management, 30(11), 21132121. doi: http://dx.doi.org/10.1016/j.wasman.2010.07.003

Ushikoshi, K., Kobayashi, T., Uematsu, K., Toji, A., Kojima, D., \& Matsumoto, K. (2002). Leachate treatment by the reverse osmosis system. Desalination, 150(2), 121-129. doi: http://dx.doi.org/10.1016/S0011-9164(02)00937-2

Valencia, R., van der Zon, W., Woelders, H., Lubberding, H. J., \& Gijzen, H. J. (2009). Achieving "Final Storage Quality" of municipal solid waste in pilot scale bioreactor landfills. Waste Management, 29(1), 78-85. doi: http://dx.doi.org/10.1016/j.wasman.2008.02.008

Warith, M. (2002). Bioreactor landfills: experimental and field results. Waste Management, 22(1), 7-17. doi: http://dx.doi.org/10.1016/S0956-053X(01)00014-9

Worrell, W. A., Reinhart, D. R., \& Vesilind, P. A. (2002). Solid waste engineering. United Kingdom: BrookslCole.

Wu, Y., Zhou, S., Qin, F., Ye, X., \& Zheng, K. (2010). Modeling physical and oxidative removal properties of Fenton process for treatment of landfill leachate using response surface methodology (RSM). Journal of Hazardous Materials, 180(1-3), 456-465. doi: http://dx.doi.org/10.1016/j.jhazmat.2010.04.052

Xie, B., Lv, Z., Lv, B. Y., \& Gu, Y. X. (2010). Treatment of mature landfill leachate by biofilters and Fenton oxidation. Waste Management, 30(11), 2108-2112. doi: http://dx.doi.org/10.1016/j.wasman.2010.06.018

Yabuta, H., Fukushima, M., Kawasaki, M., Tanaka, F., Kobayashi, T., \& Tatsumi, K. (2008). Multiple polar components in poorly-humified humic acids stabilizing free radicals: Carboxyl and nitrogen-containing carbons. Organic Geochemistry, 39(9), 1319-1335. doi: http://dx.doi.org/10.1016/j.orggeochem.2008.05.007

Zhao, R., Gupta, A., Novak, J. T., Goldsmith, C. D., \& Driskill, N. (2013). Characterization and treatment of organic constituents in landfill leachates that influence the UV disinfection in the publicly owned treatment works (POTWs). Journal of Hazardous Materials, 258259(0), 1-9. doi: http://dx.doi.org/10.1016/j.jhazmat.2013.04.026 


\section{CHAPTER 3}

\section{APPLICATION OF LANDFILL TREATMENT APPROACHES FOR THE STABILIZATION OF MUNICIPAL SOLID WASTE}

This paper has been previously published as: Bolyard, S. C., and Reinhart, D. R., Application of Landfill Treatment Approaches for Complete Stabilization of Municipal Solid Waste, Waste Management.

\section{$\underline{\text { Abstract }}$}

This research sought to compare the effectiveness of three landfill enhanced treatment approaches aimed at removing releasable carbon and nitrogen after anaerobic landfilling including flushing with clean water (FB 1), leachate recirculation with ex-situ treatment (FB 2), and leachate recirculation with ex-situ treatment and in-situ aeration (FB 3). After extensive treatment of the waste in the FB scenarios, the overall solids and biodegradable fraction were reduced relative to the mature anaerobically treated waste. In terms of the overall degradation, aeration did not provide any advantage over flushing and anaerobic treatment. Flushing was the most effective approach at removing biodegradable components (i.e. cellulose and hemicellulose). Leachate quality improved for all FBs but through different mechanisms. A significant reduction in ammonia-nitrogen occurred in FB 1 and 3 due to flushing and aeration, respectively. The reduction of chemical oxygen demand (COD) in FB 1 was primarily due to flushing. Conversely, the reduction in COD in FBs 2 and 3 was due to oxidation and precipitation during Fenton's Reagent treatment. A mass balance on carbon and nitrogen revealed that a significant fraction still remained in the waste despite the additional treatment provided. Carbon was primarily converted biologically to $\mathrm{CH}_{4}$ and $\mathrm{CO}_{2}$ in the $\mathrm{FBs}$ or removed 
during treatment using Fenton's Reagent. The nitrogen removal occurred through leaching or biological conversion. These results show that under extensive treatment the waste and leachate characteristics did meet published stability values. The minimum stability values achieved were through flushing although FB 2 and 3 were able to improve leachate quality and solid waste characteristics but not to the same extent as FB 1 .

\section{$\underline{\text { Introduction }}$}

Municipal solid waste (MSW) generation reached 1.3 billion tonnes per year globally in 2010 and is projected to increase to 2.2 billion tonnes by 2025 (Hoornweg and Bhada-Tat, 2012). The projected increase in waste generation poses a significant challenge to disposing of this waste in a controlled and sustainable manner. Landfilling is still the primary method for waste disposal in both developed and developing countries despite the push to divert waste from landfills by recycling, mechanical and biological treatment, and thermal conversion. There were approximately 1,908 operating landfills in the United States (U.S.) in 2011 and the number of mature landfills entering long-term care in the near future will increase (EPA, 2013).

After a landfill has been operated for an extended period of time and the concentration of anaerobically biodegradable organic compounds in the leachate are largely removed, leachate may contain inorganic contaminants and refractory organic by-products that potentially threaten the environment and human health. These contaminants include ammonia-nitrogen, pharmaceutical, personal care products, and heavy metals (Barlaz et al., 2002; Kjeldsen et al., 2002). Knowledge of the extent of waste stabilization and leachate quality is important when trying to determine when it is safe to release a landfill from long-term care. The extent of waste degradation is a major driver in evaluating when a landfill has reached completion and what the remaining pollution potential may be. 
Modern landfills are designed and constructed with engineered containment systems that protect the environment. U.S. regulations require that, after a landfill is closed the cell is capped to avoid additional moisture intrusion (RCRA Subtitle D). Once capping is completed, waste degradation will slow or cease all together due to a lack of adequate moisture to sustain microbial degradation (Ritzkowski et al., 2006; Scharff, 2014). Although reducing leachate generation is advantageous for landfill owners/operators this design approach is not a sustainable practice; without sufficient moisture, complete stabilization of the waste will not occur. Human health and the environment will only be protected as long as the designed containment systems remains intact (Scharff, 2014). If there is a breakdown in the integrity of the containment system long after a site has been released from post-closure care (PCC), moisture can be introduced, reinitiating the degradation process, and consequently leachate or gas emissions (Allen, 2001; Scharff, 2010; Tchobanoglous and Kreith, 2002). Therefore, to minimize the long-term environmental impact of landfills, enhanced emission reduction methods are needed prior to a breach of the containment system. It has been suggested that the introduction of liquid (e.g., flushing) and aeration are the best ways to safely reduce or end PCC (Ritzkowski et al., 2006; Stegmann et al., 2003). Flushing has been shown to remove releasable carbon and nitrogen but requires a large volume of water. Two alternative treatment processes have been suggested to reduce the water requirement and leachate requiring treatment as well as costs associated with the conventional means of flushing. Combining in-situ aeration with ex-situ chemical oxidation can provide the opportunity to remove recalcitrant carbon and biologically convert ammonia-N to nitrate or nitrogen gas.

A laboratory evaluation of three landfill enhanced treatment approaches aimed at removing releasable carbon and nitrogen species after anaerobic landfilling was conducted. The three 
landfill completion approaches include (1) flushing with clean water, (2) leachate recirculation with ex-situ treatment, and (3) leachate recirculation with ex-situ treatment and in-situ aeration. The latter scenario is referred to as Stabilization through Treatment, Aeration, and Bioreactor Leaching (STABL). This study aims to compare the effectiveness of the three approaches and to evaluate the technical and economic applications of landfill completion technologies.

\section{$\underline{\text { Materials and Methods }}$}

The feasibility of removing carbon and nitrogen to complete the treatment of landfilled waste was evaluated by operating laboratory-scale flushing bioreactors (FBs) under three different completion approaches depicted in Figure 3-1.

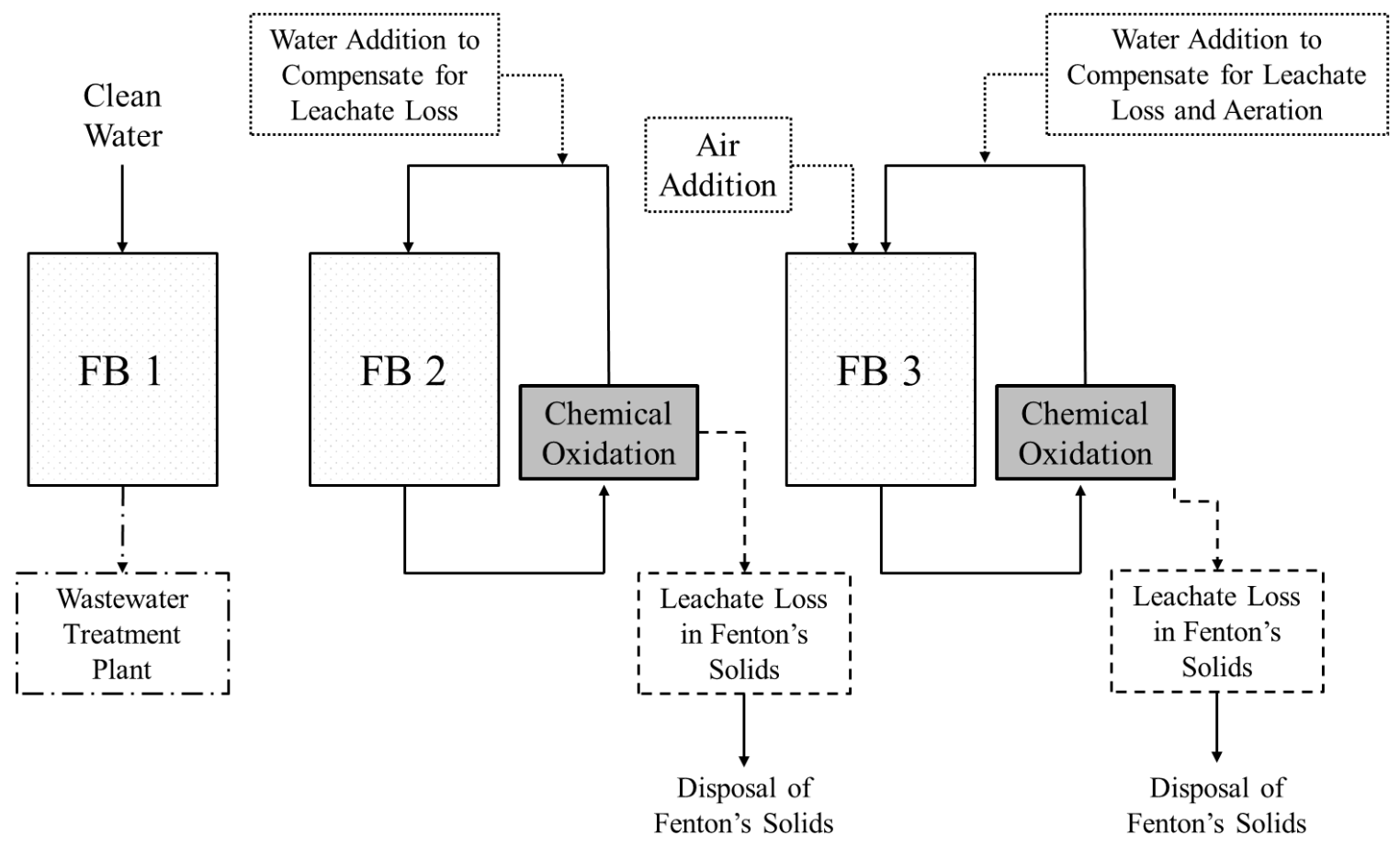

Figure 3-1. Detailed Flushing Bioreactor Operation 


\section{Laboratory-Scale Anaerobic Bioreactor Operation}

Synthetic waste was generated from new and post-consumer products. Synthetic waste was used to minimize variability in reactor operation that could result from using "real" waste and also to better define and understand the reactor inputs. A detailed breakdown of the initial waste composition can be found in the Appendix A (Table A-2) which is based on waste generated in the U.S. Each waste component was individually weighed, then combined on a plastic tarp. After mixing, liquid was added to achieve a moisture content of $50 \%$ by weight. To ensure there was adequate buffering capacity and to avoid the reactors becoming acid-stuck, sodium bicarbonate was added to the distilled (DI) water for a final concentration of $3.4 \mathrm{~g} / \mathrm{L} \mathrm{NaHCO}_{3}$. In addition to distilled water, anaerobically digested sludge, collected from a local wastewater facility, were added to provide a source of anaerobic organisms and decrease start-up time. Buffered DI water was initially added every three days to each reactor to generate a sufficient volume of leachate to be recirculated. Once a sufficient amount of leachate was generated, it was drained and recirculated every three days. This synthetic waste was degraded under anaerobic conditions in laboratory-scale anaerobic bioreactors (Bolyard and Reinhart, 2013) until a source of mature waste was achieved. The waste was deemed mature once the leachate five-day biochemical oxygen demand/chemical oxygen demand $\left(\mathrm{BOD}_{5} / \mathrm{COD}\right)$ was less than 0.10$)$.

\section{Flushing Bioreactor Design and Operation}

Eighteen FBs were operated under three different scenarios (1) flushing with clean water (FB 1), (2) recirculation of leachate, external leachate oxidation using Fenton's Reagent, with no internal oxidation (FB 2), and (3) recirculation of leachate, external leachate oxidation using Fenton's Reagent, and internal aeration (FB 3). These scenarios are depicted in Figure 3-1. The 
FBs were constructed from 20-liter high-density polyethylene containers and were modified for leachate drainage and recirculation (FBs 1-3), and air addition of $0.17 \mathrm{~m}^{3} /$ hour (FB 3 only), as shown in Figure C-1. An aquarium air compressor was used to inject air into FB 3 for continuous aeration. Air movement was countercurrent to leachate injection through a vertical perforated pipe, which was positioned approximately halfway into the waste mass to maximize nitrogen removal through both nitrification (aerobic upper zone) and denitrification processes (anoxic lower zone). Gas was not collected from the FBs.

Each FB was filled, without compaction, with approximately $4 \mathrm{~kg}$ of mature waste (wet weight) for a final density of approximately $250-300 \mathrm{~kg} / \mathrm{m}^{3}$. Leachate generated from the laboratory-scale anaerobic bioreactors was added to FBs 2 and 3 to begin the flushing process; distilled (DI) water was added to FB 1. Reactors were sealed and placed in a temperaturecontrolled room maintained at $35^{\circ} \mathrm{C} \pm 2$ for a six-month period. To account for waste heterogeneity, six reactors for each FB scenario were operated under identical conditions. Two FBs from each scenario were deconstructed for solids and leachate characterization every two months at $\mathrm{L} / \mathrm{S}$ of 3,5 , and 10 , where $\mathrm{L} / \mathrm{S}$ is the ratio of cumulative volume of clean or treated liquid added per mass of initial dry mature waste. L/S is used to normalize the treatment duration of FBs after a source of mature waste was achieved.

The detailed operation of the FBs is illustrated in Figure 3-1. All FBs were continuously monitored throughout the duration of the treatment. Leachate was removed from the bottom of each FB prior to flushing or recirculation. The leachate removed from these FBs was analyzed periodically for COD and ammonia-N. Additional characterization was completed after the deconstruction of each FBs. FB 1 was flushed with $300 \mathrm{~mL}$ of DI water while the collected leachate from FBs 2 and 3 was recirculated three times per week. Once per week the leachates 
removed from FBs 2 and 3 were treated with Fenton's Reagent prior to recirculation. Fenton's Reagent was used to remove organic matter (OM) through both oxidation and precipitation. During operation of FBs 2 and 3, DI water was added to ensure at least $300 \mathrm{~mL}$ of liquid was recirculated each time. This liquid was added to compensate for leachate losses through Fenton's solids removed (FBs 2 and 3) and aeration (FB 3 only). See Appendix B for the breakdown of liquid added to each FB (Table B-2).

Leachate collected weekly from FBs 2 and 3 for chemical oxidation was treated using a Fenton's Reagent dosage of 0.4 molar ratio of $\mathrm{Fe}$ to $\mathrm{H}_{2} \mathrm{O}_{2}$ and $1 \mathrm{~g} \mathrm{H}_{2} \mathrm{O}_{2}$ to $1 \mathrm{~g} \mathrm{COD}$ as outlined in Batarseh et al. (2007). After treatment, the leachate was set aside for settling, centrifuged for ten minutes, and then filtered ( $1.5 \mu \mathrm{m}$ Whatman $934-\mathrm{AH}$ glass filter) to remove any precipitated solids remaining in the supernatant. Solids generated from Fenton's Reagent treatment were dried and stored for future studies. These solids would require management. Aliquots of the filtered leachate were removed for COD analysis. Addition of mercury sulfate was required to remove the interference experienced in this study from chloride introduced through Fenton's Reagent treatment.

\section{Solid Waste Characterization}

Waste removed from each of the deconstructed FBs was characterized for moisture content and biodegradable volatile solids (VS). One FB from each deconstructed set was characterized for carbon, nitrogen, cellulose (C), hemicellulose (H), and lignin (L) content. Moisture content was determined following Standard Methods 2540G (APHA, 2005). Biodegradable VS were determined following the traditional loss-on-ignition method (APHA, 2005) by heating each sample at $550^{\circ} \mathrm{C}$ after plastic, tire pieces, rope, and other nonbiodegradable but ignitable 
components were removed. The weight of the components removed were recorded and utilized to quantify the percent of nonbiodegradable VS in each sample. Carbon, nitrogen, C, L, and H content of the biodegradable solid waste fraction were analyzed by an outside laboratory. C, H, and L were determined following the method outlined in Wang et al. (2011) Carbon and nitrogen were measured using a CHN analyzer (Perkin-Elmer PE 2400 Elemental Analyzer). The initial and mature wastes were characterized following the same methods.

\section{Leachate Characterization}

Leachate COD was continuously monitored throughout the operation of the FBs. After each reactor was deconstructed the collected leachate was characterized for $\mathrm{COD}, \mathrm{BOD}_{5}, \mathrm{pH}$, ammonia-nitrogen, nitrite-nitrogen, and nitrate-nitrogen following the Standard Methods for the Examination of Water and Wastewater (APHA, 2005). Total Kjeldahl nitrogen (TKN) was determined using a simplified method developed by Hach (U.S. EPA Method 10242). A microbial community analysis was completed on leachate removed from FBs 1-3 at L/S of 10 by an outside laboratory. Bacteria and archaea were extracted from the biomass in the collected leachate using a MoBio Powersoil Kit. Polymerase chain reaction was used to amplify the extracted samples and a high-throughput method discussed by Caporaso et al. (2010), was used to analyze the microbial community data.

\section{Biochemical Methane Potential}

Biochemical methane potential (BMP) assays were used to determine the emission potential of waste removed from the FBs following the method described by Owens and Chynoweth (1992). An anaerobic inoculum medium was prepared by combining anaerobically digested sludge obtained from a local domestic wastewater treatment facility with nutrients required to 
sustain an anaerobic environment for at least 90 days. BMP assays were prepared individually in 250-mL serum bottles processed under anaerobic conditions (maintained through continuous $\mathrm{N}_{2}$ flushing). Serum bottles were filled with dry milled solids for a final concentration of $2 \mathrm{~g} / \mathrm{L}$ of organic carbon, after which $100 \mathrm{~mL}$ of anaerobic inoculum were added using a peristaltic pump. Blanks containing only the anaerobic inoculum were also included in this study and monitored over the same period as the test samples. All bottles were sealed with a rubber stopper and aluminum crimp and incubated at $35 \pm 2^{\circ} \mathrm{C}$.

Gas quality and quantity from BMP assays were measured periodically over a 120-day period. Gas samples were removed from the headspace during this period with a frictionless syringe to measure the volume generated as well as the carbon dioxide $\left(\mathrm{CO}_{2}\right)$ and methane $\left(\mathrm{CH}_{4}\right)$ content. The gas quality was measured using a Shimadzu-14a gas chromatograph equipped with a thermal conductivity detector and Carboxyn-1000 column. The detailed GC method used is described by Bolyard et al. (2013).

\section{$\underline{\text { Results and discussion }}$}

\section{Solid Waste Analysis and Breakdown}

The characteristics of the mature and FB waste are provided in Appendix C (Table C-4). In order to compare the distribution of solids fraction over time relative to the mature waste, it was assumed that the nonbiodegradable VS and metal content was constant, as there should be no changes in either of these fractions during waste degradation. The overall degradation of the waste was calculated by multiplying the initial VS content of the mature waste $\left(\mathrm{VS}_{\mathrm{MW}}\right)$ by the percent reduction determined using Equation 3-1 at each L/S. Figure 3-2 summarizes the distribution of the final FB waste relative to the mature waste. 
Percent Reduction in $V S=\frac{V S_{M W}-V S_{L / S}}{V S_{M W}} \times 100$

After reaching L/S of 10, approximately $10 \%$ of the waste was removed for FBs 1-3 relative to the mature waste. This reduction equates to an approximate decrease in the initial biodegradable fraction of FBs 1 and 3 of $45 \%$ and FB 2 of $48 \%$. It appeared that in this study aeration did not provide any additional benefit in terms of degradation of the biodegradable fraction in FB 3, potentially due to the partial aeration of the waste and lower moisture content. The moisture content in FB 3 was less than $41 \%$ while FBs 1 and 2 moisture content was greater than 50\% during treatment. Although liquid was added to compensate for leachate loss, a lower moisture content in FB 3 was observed in each deconstructed FB. This lower moisture content was caused by the evaporation of leachate during in-situ aeration (Read et al., 2001).

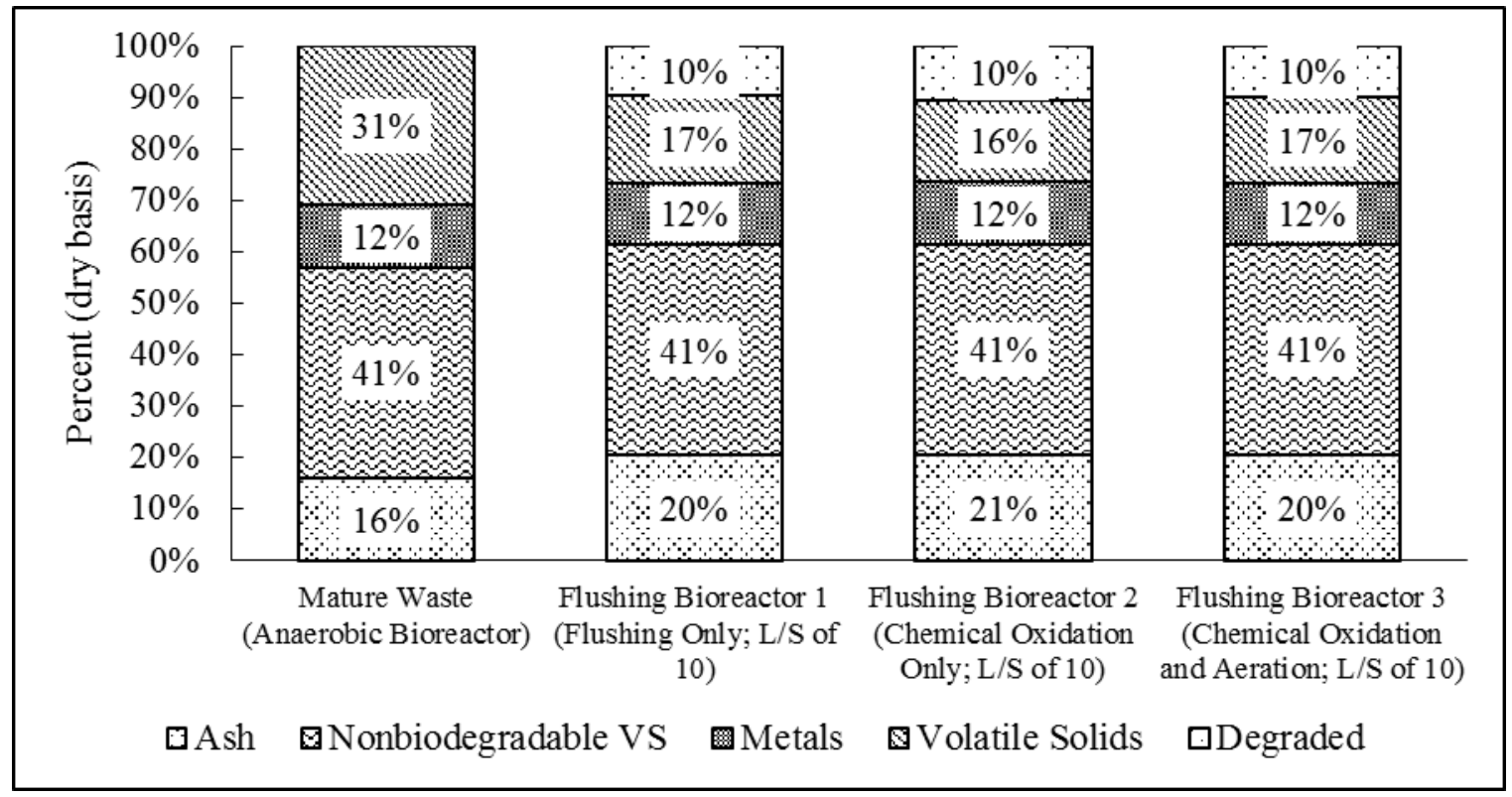

Figure 3-2. Distribution of the Final Solid Waste Components Relative to the Mature Waste 
The biodegradable fraction of each waste sample was further analyzed for carbon and nitrogen content and $\mathrm{C}, \mathrm{H}$, and $\mathrm{L}$ to identify the degradation of the different waste components for each FB. The waste characteristics of FB 2 at L/S of 3 were excluded from data analysis. These reactors had higher carbon, nitrogen, $\mathrm{C}, \mathrm{H}$, and $\mathrm{L}$ content than the mature waste which could be attributed to the heterogeneity of the waste and the inclusion of poorly degraded cellulosic material during preparation of the reactors and analytical samples. $\mathrm{C}, \mathrm{H}$, and $\mathrm{L}$ are the primary components of the biodegradable fraction of MSW (Booker and Ham, 1982) but are degraded at variable rates under different conditions. $\mathrm{C}$ and $\mathrm{H}$ can undergo anaerobic decomposition in a conventional MSW landfill (Booker and Ham, 1982; Wang et al., 2011; Wang et al., 2013). Lignin, on the other hand, is recalcitrant under anaerobic conditions (Colberg, 1988). Therefore $(\mathrm{C}+\mathrm{H}) / \mathrm{L}$ and $\mathrm{C} / \mathrm{L}$ ratios can be used as indicators of the extent of anaerobic waste decomposition. A decrease in these ratios signifies more complete degradation of wastes anaerobically (Wang et al., 2011; Wang et al., 2013). The mature waste had a (C+H)/L and $\mathrm{C} / \mathrm{L}$ of 2.2 and 1.2, respectively. An initial decrease in $\mathrm{C} / \mathrm{L}$ and $(\mathrm{C}+\mathrm{H}) / \mathrm{L}$ was observed for all FBs (Figures 3-3 and C-2, respectively). If cellulose is removed relative to lignin, the $\mathrm{C} / \mathrm{L}$ and $(\mathrm{C}+\mathrm{H}) / \mathrm{L}$ will decrease as observed under flushing (FB 1) and anaerobic conditions (FBs 1 and 2). Lignin may degrade aerobically (Komilis and Ham, 2003; Tuomela et al., 2000), which may explain the significantly higher $\mathrm{C} / \mathrm{L}$ for FB 3 than FBs 1 and 2 . The higher $\mathrm{C} / \mathrm{L}$ ratio may also be a result of cellulosic material becoming more accessible due to lignin degradation. 


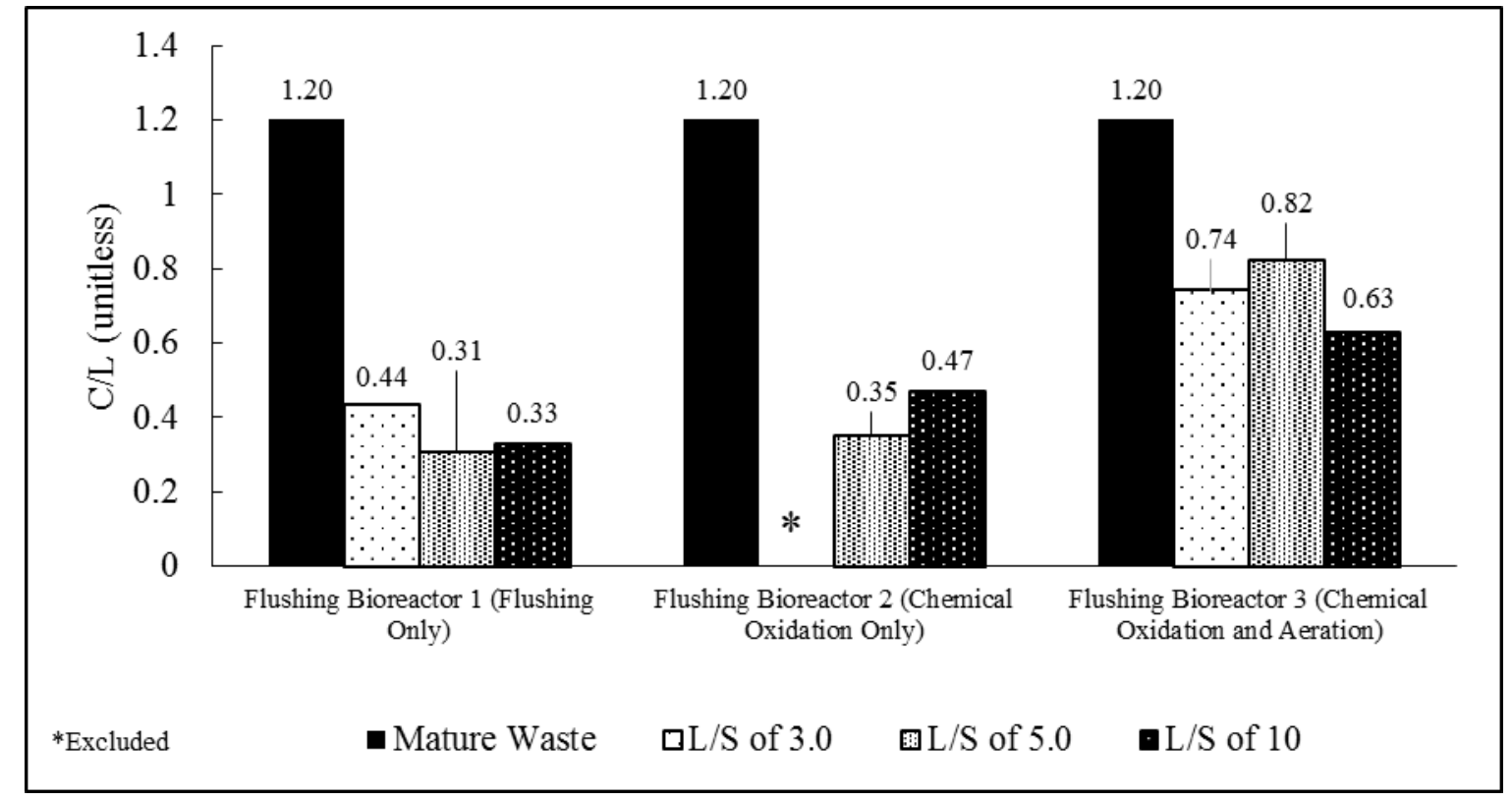

Figure 3-3. Cellulose to Lignin Ratio of Waste Removed from Flushing Bioreactors BMP assays were used to assess the remaining $\mathrm{CH}_{4}$ emission potential of the waste for each FB scenario. Results are expressed as the remaining emission potential in terms of $\mathrm{m}^{3}$ of $\mathrm{CH}_{4}$ per $\mathrm{Mg}$ of dry waste (Figure 3-4). The mature waste had a $\mathrm{CH}_{4}$ potential of $47 \mathrm{~m}^{3} / \mathrm{Mg}$ after anaerobic treatment. The emission potential was reduced in all FBs; FB 1 had the lowest BMP at each L/S, suggesting that the flushing process was effective in removing biodegradable components that can undergo anaerobic digestion (primarily cellulose and hemicellulose). Leachate recirculation/chemical oxidation in FB 2 was not as successful at reducing the BMP relative to FB 1 (FB 2 values were $55 \%$ to $200 \%$ higher). FB 3 had the highest remaining BMP which aligns well with the higher $\mathrm{C} / \mathrm{L}$ and carbon/nitrogen of the waste in FB 3. The higher BMP in FB 3 may be due to the degradation of lignin making cellulosic materials more accessible under anaerobic conditions. 


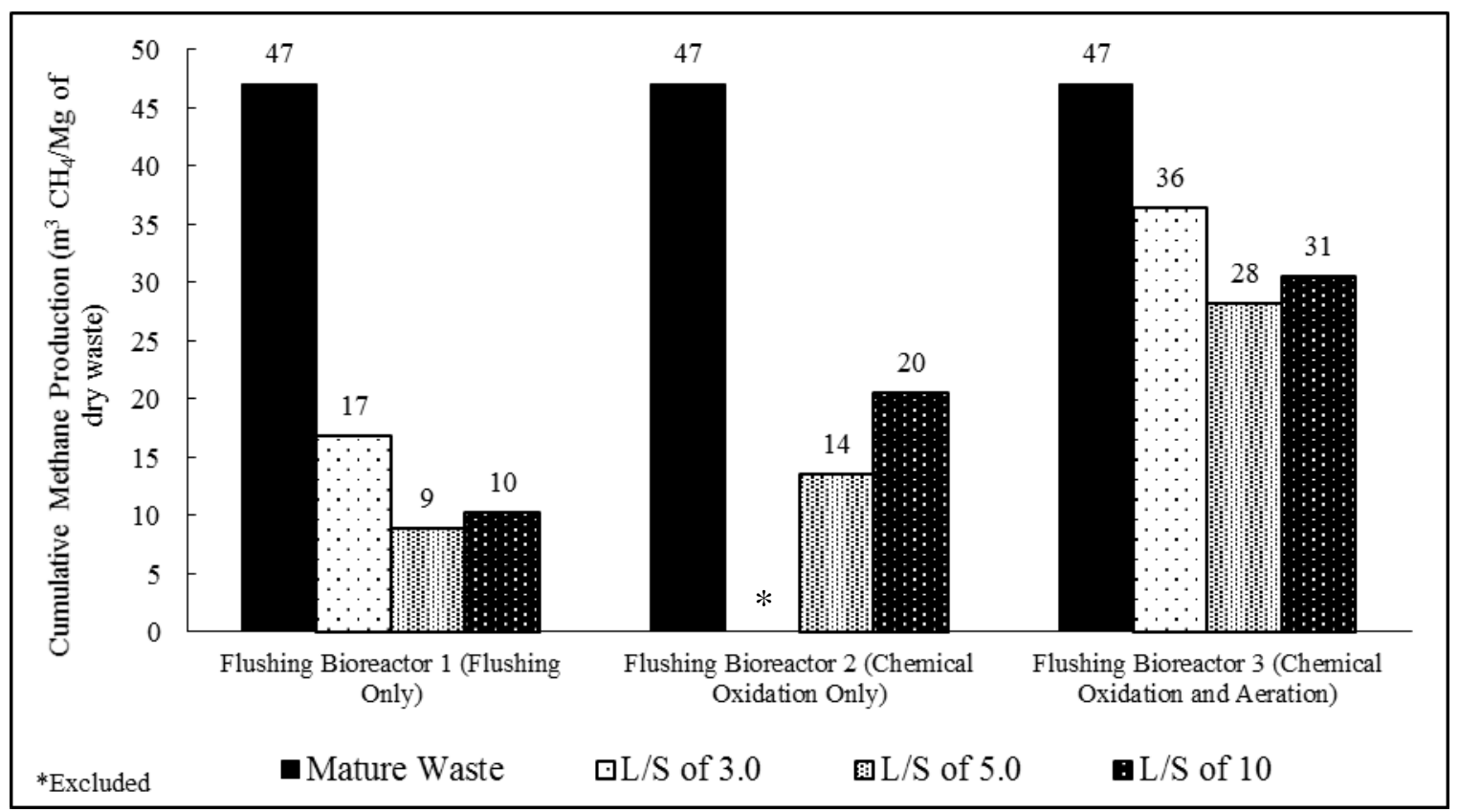

Figure 3-4. Remaining Methane Potential of Solid Waste Samples from FBs 1-3

\section{Leachate Characteristics}

The characteristics of the mature leachate used for the initial flushing of FBs 2 and 3 are summarized in Table C-3 of Appendix C. The BOD/COD was approximately 0.03, which, according to many studies, suggests the waste was mature (Ehrig, 1984; Kang et al., 2002; Tchobanoglous and Kreith, 2002). The pH in FBs 1 and 2 ranged between 6.6 S.U and 7.8 S.U. during operation, while the $\mathrm{pH}$ in FB 3 was between 7.5 S.U. and 8.9 S.U. This increase in $\mathrm{pH}$, under aerobic conditions, has been observed by other researchers (Raga and Cossu, 2013; Zhong et al., 2009).

A significant reduction in ammonia-nitrogen was observed in FBs 1 and 3, while less in FB 2 (Figure 3-5). Flushing was responsible for the decrease in ammonia-nitrogen although flushing would generate a significant volume of contaminated leachate, which is costly to treat externally. An initial decrease in ammonia-nitrogen concentration was observed in all FBs which could be attributed to physical (sorption or washout) or biological reactions. Neither washout nor 
biological reactions would be expected in FB 2. While the concentration drop was significant, the mass loss in FB 2 was small and may be attributed to sorption. A study by Berge et al. (2006) observed that $10 \%-20 \%$ of the initial ammonia-nitrogen was sorbed to the waste. This reduction could also be a result of nitrification but this would not account for all of the nitrogen loss.

Further, the loss was short-lived and therefore probably not a biological reaction.

Reduction of ammonia-nitrogen in FB 3 (reaching concentrations below $1.0 \mathrm{mg} / \mathrm{l}$ ) was due to the biological conversion to nitrate-nitrogen, nitrite-nitrogen, and nitrogen gas $\left(\mathrm{N}_{2}\right)$ through nitrification, denitrification, and anaerobic ammonia oxidation (Anammox, which is the direct conversion of ammonia-nitrogen and nitrite-nitrogen to $\mathrm{N}_{2}$ ). The presence of nitrate-nitrogen and nitrite-nitrogen in the leachate supports the assumption that nitrification was occurring. However, exhaust gas was not analyzed, therefore it was not possible to quantify the nitrogen conversion to $\mathrm{N}_{2}$. Because nitrate/nitrite was lower than would be expected based on ammonianitrogen removal, denitrification was assumed to have occurred in the non-aerated bottom of the reactor. The microbial community analysis revealed that Anammox bacteria (i.e., planctomyces phyla (Berge et al., 2006; Jetten et al., 2001)) were present in the leachate collected from FB 3 but were not detected in FBs 1 and 2. 


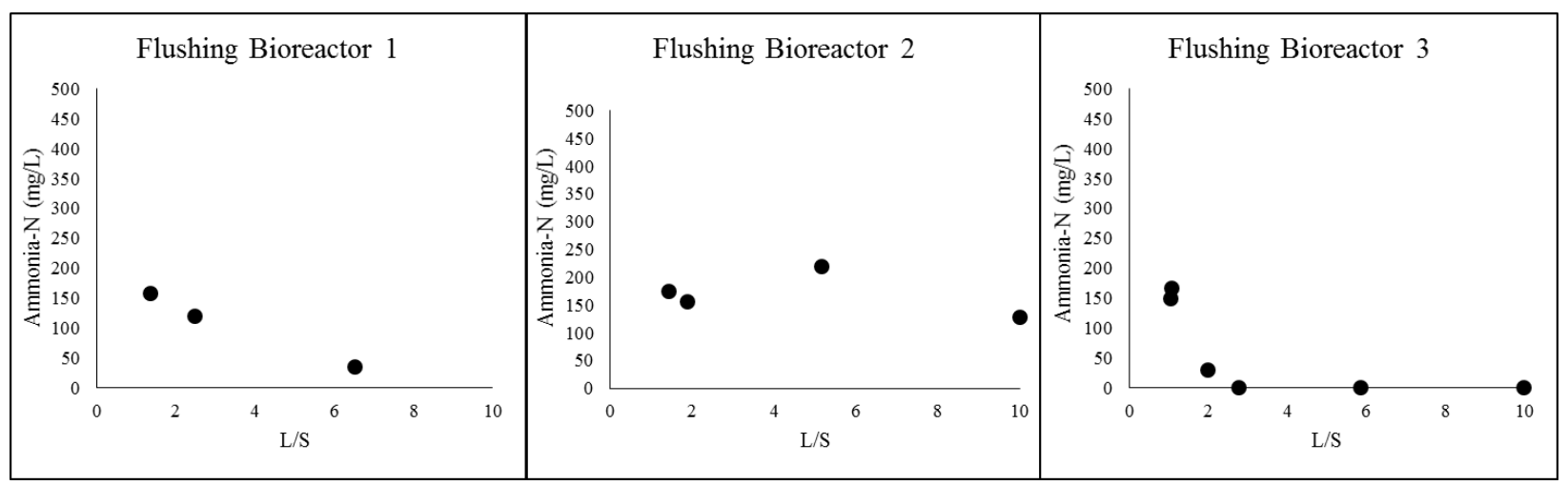

Figure 3-5. Ammonia-Nitrogen Concentration in Flushing Bioreactor Scenarios

COD for FBs 1-3 was reduced considerably (Figure 3-6), however through different mechanisms. The final concentrations of COD in FBs $1-3$ were $150 \mathrm{mg} / \mathrm{L}, 347 \mathrm{mg} / \mathrm{L}$ and 1,250 $\mathrm{mg} / \mathrm{L}$, respectively. Due to the chloride interference in COD measurements, the carbon removal during some of the treatment period was interpolated for FBs 2 and 3 (Figure 3-6). The reduction of COD in FB 1 was primarily due to flushing and the organic matter in the leachate generated would, most likely, require external treatment. Conversely, the reduction in COD in FBs 2 and 3 was due to oxidation and precipitation during Fenton's Reagent treatment. FB 3 had a higher final COD concentration relative to FBs 1 and 2. Presumably the higher concentration of COD could be a result of leachate evaporation due to in-situ aeration (Read et al., 2001). From a mass perspective, the COD present in the leachate FB 3 was approximately twice as high as FB 2. This trend can be a result of organics decomposition or the production of HA under semi-aerobic conditions. Note that a chemical sludge was produced from the Fenton's Reagent process which would need to be disposed, although there is a potential for re-leaching of the precipitated COD if placed in a landfill. The potential for re-leaching COD needs to be evaluated further. 


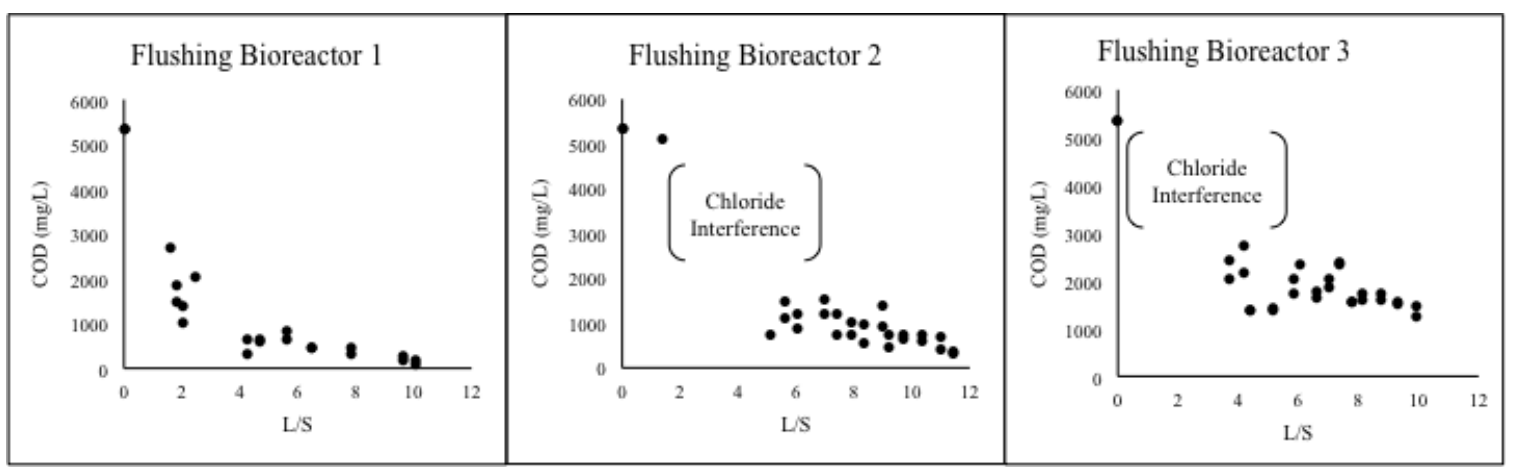

Figure 3-6. Chemical Oxygen Demand Concentration in Flushing Bioreactor Scenarios

\section{Carbon and Nitrogen Balance}

The fate of the biodegradable carbon and nitrogen after completion of FB operation (L/S of 10) under the three different scenarios was determined using solids and leachate data. Typical mass balance calculations were used (i.e., concentration times volume). This information was useful in understanding the various mechanisms observed in each treatment process. The remaining carbon in the waste for FBs 1-3 is summarized in Figure 3-7. It is assumed that the carbon was biologically converted to $\mathrm{CH}_{4}$ and $\mathrm{CO}_{2}$ in the $\mathrm{FBs}$ or removed during treatment using Fenton's Reagent. Biological carbon conversion was compared to the reduction in BMP relative to the mature waste. Removal through Fenton's Reagent treatment was limited by the low leachability of carbon from the waste. 


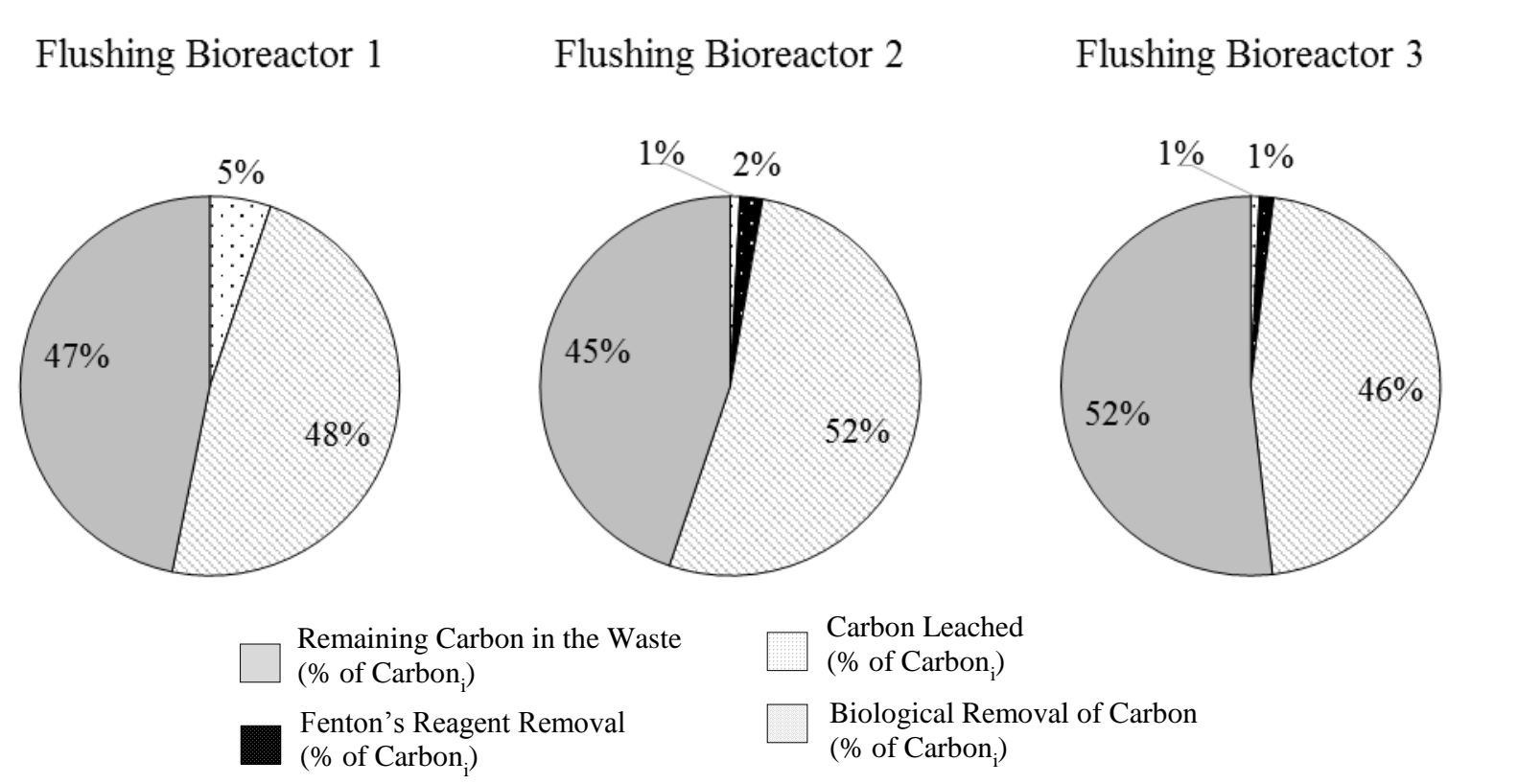

Figure 3-7. Summary of the Fate of Carbon in the Biodegradable Waste Fraction (L/S of 10)

Carbon sources in waste can be categorized as biogenic and fossil. Fossil carbon includes nonrenewable materials and is mainly comprised of rubber, textiles, and plastics in MSW landfills (EPA, 2013). Biogenic carbon is primarily found in the biodegradable fraction of waste. Approximately $36 \%$ of the carbon in the mature waste was biogenic after anaerobic treatment with the remaining bound in plastics and tire chips. The latter fraction was calculated based on the initial waste composition and literature values of the carbon content of plastics and tire chips (Worrell et al., 2002). At the completion of the FB operation (L/S of 10), the biogenic carbon fraction declined to $17 \%, 16 \%$, and $19 \%$ of the carbon present, respectively. These data suggest that all FBs were successful at removing biogenic carbon to roughly the same degree despite the different treatments. After FB operation (L/S of 10), the total stored carbon would be approximately $81 \%, 80 \%$, and $83 \%$ of the carbon in the mature waste, respectively.

Nitrogen remaining in the waste was approximately $76 \%, 75 \%$, and $73 \%$ of the content in the mature waste despite the additional treatment provided (Figure 3-8). The remaining nitrogen was 
resistant to physical leaching, perhaps due to the lack of biodegradation of complex nitrogencontaining organic compounds in yard waste and wood. The nitrogen removed was leached or converted biologically. In FB 1, the nitrogen removed from the waste was accounted for in the leachate. Flushing reduced ammonia-nitrogen to a final concentration of $6.6 \mathrm{mg} / \mathrm{L}$; however exsitu treatment of this leachate would represent a significant cost to landfill owners. Nitrogen removal was approximately the same in FBs 1 and 2. The mass balance (Figure 3-8) shows that $10 \%$ of the nitrogen was not accounted for perhaps due to sorption. FB 3 had a slightly higher percent nitrogen $(27 \%)$ reduction. In-situ aeration biologically converted $22 \%$ of the leached and recycled nitrogen, and $5 \%$ of the nitrogen was found in the removed leachate, needing to be treated ex situ. FB 3 was the most effective method for ammonia-nitrogen removal.

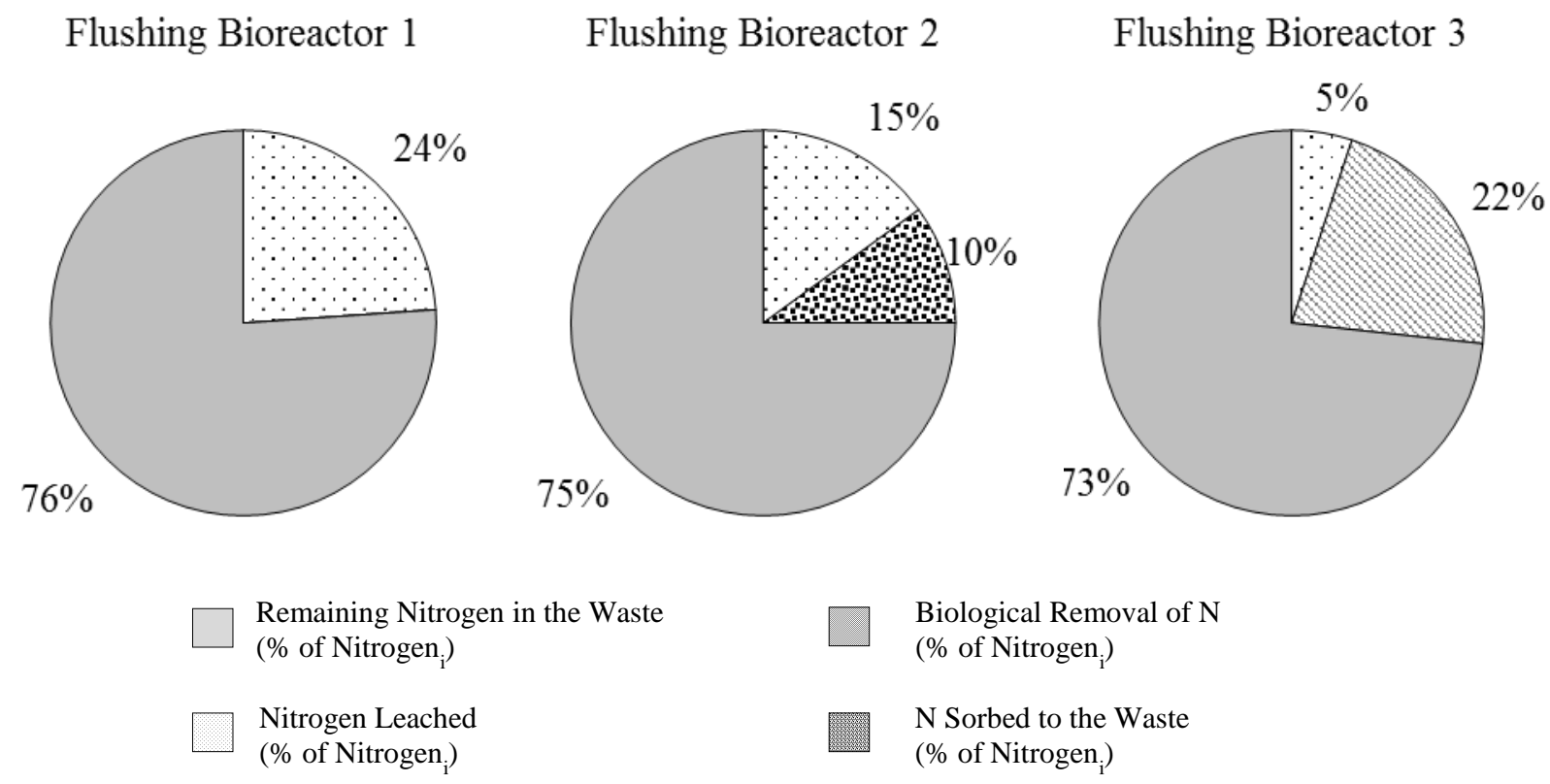

Figure 3-8. Summary of the Fate of Nitrogen in the Biodegradable Waste Fraction (L/S of 10) 


\section{Performance Assessment using Stability Criteria}

Performance based assessments are commonly used to evaluate the progress of a landfill towards completion and the end of PCC. Numerous studies have developed stability indicators to better understand whether a landfill has reached completion (Brandstätter et al., 2015; Laner et al., 2012; Valencia et al., 2009; Zheng et al., 2015). Despite these efforts there are still gaps in understanding what is actually required to achieve such values. Data in this study supported the potential for mature waste treatment by anaerobic landfill processes to require additional treatment to stabilize and for leachate quality to improve under the three FB scenarios. These data are presented in Tables 3-1 and 3-2 along with stability indicators referenced in the literature for solid waste and leachate characteristics.

Table 3-1. Comparison of Solid Waste Stability Indicators

\begin{tabular}{|c|c|c|c|c|c|}
\hline Parameter & $\begin{array}{c}\text { Stabilized Waste } \\
\text { Characteristics }\end{array}$ & Mature Waste & $\begin{array}{c}\text { Flushing } \\
\text { Bioreactor 1 }\end{array}$ & $\begin{array}{c}\text { Flushing } \\
\text { Bioreactor 2 }^{\text {a }}\end{array}$ & $\begin{array}{c}\text { Flushing } \\
\text { Bioreactor 3 }^{\text {a }}\end{array}$ \\
\hline $\begin{array}{c}\text { Biodegradable Volatile } \\
\text { Solids (\% of dry weight) }\end{array}$ & $<25 \%$ & 31 & 24 & 25 & 27 \\
\hline C/L & $0.16-0.6^{\mathrm{c}}$ & 1.2 & 0.33 & 0.47 & 0.62 \\
\hline $\begin{array}{c}\text { Biochemical Methane } \\
\text { Potential (21 days) } \mathrm{m}^{3} \\
\mathrm{CH}_{4} / \mathrm{Mg} \text { total dry waste }\end{array}$ & $10-15^{\mathrm{d}}$ & 29 & 3.6 & 9.0 & 15 \\
\hline
\end{tabular}

a. L/S of 10

b. Knox et al., 2005

c. Barlaz, 2006

d. Cossu et al., 2007; Knox et al., 2005; Prantl et al., 2006; Ritzkowski and Stegmann, 2013 
Table 3-2. Comparison of Leachate Stability Indicators

\begin{tabular}{|c|c|c|c|c|c|}
\hline $\begin{array}{c}\text { Leachate Stability } \\
\text { Indicators }\end{array}$ & $\begin{array}{c}\text { Stabilized } \\
\text { Waste } \\
\text { Characteristics }\end{array}$ & Mature Waste & $\begin{array}{c}\text { Flushing } \\
\text { Bioreactor 1 }\end{array}$ & $\begin{array}{c}\text { Flushing } \\
\text { Bioreactor 2 }\end{array}$ & $\begin{array}{c}\text { Flushing } \\
\text { Bioreactor 3 }\end{array}$ \\
\hline BOD/COD (unitless) & $<0.1^{\mathrm{b}}$ & 0.03 & 0.060 & 0.068 & 0.0024 \\
\hline BOD (mg/L) & $<100^{\mathrm{c}}$ & 161 & 9 & 23.5 & 3 \\
\hline COD (mg/L) & $<200^{\mathrm{d}}$ & 5,350 & 150 & 347 & 1250 \\
\hline Ammonia-N (mg/L) & $<10^{\mathrm{e}}$ & 472 & 6.6 & 129 & 0.45 \\
\hline
\end{tabular}

a. $\mathrm{L} / \mathrm{S}$ of 10

b. Booker and Ham, 1982; Cossu et al., 2007; Kjeldsen et al., 2002

c. Kjeldsen et al., 2002

d. Cossu et al., 2007

e. Knox et al., 2005

The proposed target value for biodegradable volatile solids is $25 \%$ of dry matter (Knox et al., 2005); biodegradable volatile solids content in all FBs declined but only FBs 1 and 2 results were at or just below $25 \%$. This fraction does not provide much information about the specific components remaining. Therefore this parameter might not be relevant unless combined with other indicators. For example, changes in $\mathrm{C} / \mathrm{L}$ are commonly used to assess the extent and potential of anaerobic waste decomposition. A study by Barlaz (2006) reported C/L of 0.16-0.60 for excavated refuse that was landfilled for over 15 years. Overall, the C/L values achieved in this study agree with literature values and support waste stabilization.

$\mathrm{BMP}$ is another parameter used to measure the remaining carbon that can be degraded anaerobically (Barlaz, 2006). Typically values reported in the literature related to BMP and waste stability are from tests conducted over a 21-day period as opposed to a 90-day period. Therefore proposed values for the $\mathrm{BMP}$ of waste in Table 1 represent results at day $21\left(\mathrm{BMP}_{21}\right)$ for comparison with the literature. The $\mathrm{BMP}_{21}$ was reduced relative to the initial mature waste in all FBs and also was at or below the proposed stability value. FB $1 \mathrm{BMP}_{21}$ results suggested that flushing was the most effective method at removing the biodegradable fraction of the waste. On the other hand, $\mathrm{BMP}_{21}$ values at each $\mathrm{L} / \mathrm{S}$ were higher than anticipated for FBs 2 and 3, given the 
extensive treatments, but still fell within the range of the proposed target values by L/S of 10 . The use of BMP as a termination indicator is useful but setting such low thresholds might not be attainable and realistic under field conditions.

Leachate quality is the most commonly used indicator of landfilled waste stability but alone will not provide a comprehensive picture of degree of treatment. The BOD/COD ratio did not change significantly as the mature leachate ratio was already $<0.1$ prior to the additional treatment. This indicator alone does not represent the extent of stabilization of the solid waste as it was observed that BOD/COD declined faster than $\mathrm{C} / \mathrm{L}$. During treatment data showed that the solid waste was further stabilized (Figures 5 and 6 ) while the BOD/COD did not change significantly.

$\mathrm{BOD}_{5}$ and $\mathrm{COD}$ were significantly reduced after treatment in all $\mathrm{FBs} . \mathrm{BOD}_{5}$ after the initial anaerobic treatment remained above the suggested value of less than $100 \mathrm{mg} / \mathrm{L}$. All FBs were able to achieve a $\mathrm{BOD}_{5}$ less than $24 \mathrm{mg} / \mathrm{L}$. Achieving a COD of less than $200 \mathrm{mg} / \mathrm{L}$ would require additional treatment in FBs 2 and 3, whereas flushing attained the aforementioned standard. Even though FB 1 was the most effective at reducing COD, the mass discharged from this scenario was approximately $7.0 \mathrm{~kg}$ of carbon/ $\mathrm{Mg}$ of waste whereas FBs 2 and 3 discharged 1.1 and $1.0 \mathrm{~kg}$ of carbon/Mg of waste, respectively. Leachate recirculation is one reason for the higher concentration observed in FBs 2 and 3, but the in-situ treatment was able to reduce the mass of carbon discharged and needs to be treated off-site.

Ammonia-nitrogen is the main concern after operating an anaerobic bioreactor since this contaminant is persistent. This study showed that in order to achieve an ammonia-nitrogen concentration less than $10 \mathrm{mg} / \mathrm{L}$, aeration and flushing are the most effective methods. The mass 
of nitrogen discharged from FB 1 ( $0.8 \mathrm{~kg}$ of nitrogen/Mg of waste) was, again, much greater in comparison to FBs 2 and 3 (0.68 and $0.17 \mathrm{~kg}$ of nitrogen/Mg of waste, respectively).

Overall, these results show that under extensive treatment the waste and leachate characteristics did meet published stability values and that going beyond the bioreactor landfill can further stabilize solids as well as reduce leachate contaminants. Comparing the stability indicators to the performance of FBs 1-3 shed some light on the ability to meet such standards, which is encouraging. In actual practice it is challenging to completely aerate, leach, or wet all of the waste due to heterogeneity of the waste and compaction therefore it is expected that the same extent of removal would not be achievable in the field. Field studies are needed to evaluate the feasibility of reaching the referenced stability indicators in Tables 1 and 2. Given the extensive treatment it appears that a biodegradable volatile solids content of $17 \%$ dry matter, C/L of 0.31 , and a $\mathrm{BMP}_{21}$ of $3.6 \mathrm{~m}^{3} \mathrm{CH}_{4} / \mathrm{Mg}$ waste were the minimum values that could be achieved by flushing. In terms of leachate quality COD, BOD, and ammonia-nitrogen concentrations of 9 $\mathrm{mg} / \mathrm{L}, 150 \mathrm{mg} / \mathrm{L}$, and $7 \mathrm{mg} / \mathrm{L}$, respectively, can be achieved by operating a landfill using the flushing approach. FBs 2 and 3 were able to stabilize the waste in terms of improving leachate quality and solid waste characteristics but not to the same extent as FB 1 and the costs were significant (see Cost Analysis in the Supplemental Information). Despite the successful reduction of leachate and solid waste parameters FB 1 has a significant mass of both carbon and nitrogen that was discharged relative to FBs 2 and 3 and there was a significant portion of initial carbon and nitrogen remaining in the waste. 


\section{Conclusions}

This research provided information regarding the extent of waste decomposition possible under different treatment scenarios. Overall going beyond the bioreactor landfill can further stabilize solids as well as reduce leachate contaminants. Despite this further stabilization there are components still remaining (including methane potential) and the additional costs are considerable.

After extensive treatment of the waste in the FB scenarios, the overall solids, and biodegradable fraction were reduced relative to the mature waste. Our results suggest that aeration did not provide any additional benefit in terms of solid fraction treatment, although ammonia-N oxidation was achieved. The flushing process was effective at removing biodegradable components that can undergo anaerobic digestion (e.g., cellulose and hemicellulose).

All FBs were successful at improving the overall leachate quality but through different mechanisms. Carbon removal in FBs 1 was due to flushing and biological processes but generated a significant leachate volume that would need to be treated externally while removal in FBs 2 and 3 occurred via Fenton's Reagent and in situ biological processes, which reduces the costs associated with external treatment of the generated leachate, while increasing the cost of treatment of residuals. Nitrogen removal also occurred through flushing in FB 1 and ammonia-N oxidation in FB 3. Minimal removal occurred in FB 2. Despite the additional treatment, a significant portion of initial carbon and nitrogen remained in the waste. 


\section{$\underline{\text { References }}$}

Allen, A. (2001). Containment landfills: the myth of sustainability. Engineering Geology, 60(14), 3-19. doi: http://dx.doi.org/10.1016/S0013-7952(00)00084-3

APHA. (2005). Standard Methods for the Examination of Water and Wastewater.

Barlaz, M. A. (2006). ForHA est products decomposition in municipal solid waste landfills. Waste Management, 26(4), 321-333. doi: http://dx.doi.org/10.1016/j.wasman.2005.11.002

Barlaz, M. A., Rooker, A. P., Kjeldsen, P., Gabr, M. A., \& Borden, R. C. (2002). Critical Evaluation of Factors Required To Terminate the Postclosure Monitoring Period at Solid Waste Landfills. Environmental Science \& Technology, 36(16), 3457-3464. doi: 10.1021/es011245u

Batarseh, Reinhart, D., \& Daly, L. (2007). Liquid Sodium Ferrate and Fenton's Reagent for Treatment of Mature Landfill Leachate. Journal of Environmental Engineering, 133(11), 1042-1050. doi: doi:10.1061/(ASCE)0733-9372(2007)133:11(1042)

Berge, N. D., Reinhart, D. R., Dietz, J., \& Townsend, T. (2006). In situ ammonia removal in bioreactor landfill leachate. Waste Management, 26(4), 334-343. doi: http://dx.doi.org/10.1016/j.wasman.2005.11.003

Bolyard, S. C., \& Reinhart, D. R. (2013). Pump and Treat Aerobic Flushing Bioreactor Landfill. Paper presented at the Fourteenth International Waste Management and Landfill Symposium, Sardinia, Italy.

Bolyard, S. C., Reinhart, D. R., \& Santra, S. (2013). Behavior of Engineered Nanoparticles in Landfill Leachate. Environmental Science \& Technology, 47(15), 8114-8122. doi: $10.1021 / \mathrm{es} 305175 \mathrm{e}$

Booker, T. J., \& Ham, R. K. (1982). Stabilization of Solid Waste in Landfill. ASCE Journal of Environmental Engineering, 108(6), 1089-1128.

Brandstätter, C., Laner, D., \& Fellner, J. (2015). Carbon pools and flows during lab-scale degradation of old landfilled waste under different oxygen and water regimes. Waste Management, 40, 100-111. doi: http://dx.doi.org/10.1016/j.wasman.2015.03.011

Caporaso, J. G., Kuczynski, J., Stombaugh, J., Bittinger, K., Bushman, F. D., Costello, E. K., . . . Knight, R. (2010). QIIME allows analysis of high-throughput community sequencing data. Nat Meth, 7(5), 335-336. doi: http://www.nature.com/nmeth/journal/v7/n5/suppinfo/nmeth.f.303_S1.html

Colberg, P. J. (1988). Anaerobic Microbial Degradation of Cellulose, Lignin, Oligolignols, and Monoaromatic Lignin Derivatives. In J. B. Zehnder (Ed.), Biology of Anaerobic Microorganisms (pp. 333-372): New York: Wiley-Liss.

Cossu, R., Lai, T., \& Piovesan, E. (2007). Proposal of a methodology for assessing the final storage quality of a landfill. Paper presented at the International Waste Management and Landfill Symposium, S. Margherita di Pula, Cagliari, Italy.

Ehrig, H. J. (1984). Treatment of sanitary landfill leachate: Biological treatment. Waste Management \& Research, 2(2), 131-152. doi: http://dx.doi.org/10.1016/0734242X(84)90136-8

EPA, U. S. (2013). Municipal Solid Waste (MSW) in the United States: 2011 Facts and Figures. Hoornweg, D., \& Bhada-Tat, P. (2012). What a Waste: A Global Review of Solid Waste Management (Vol. 15). 
Jetten, M. S. M., Wagner, M., Fuerst, J., van Loosdrecht, M., Kuenen, G., \& Strous, M. (2001). Microbiology and application of the anaerobic ammonium oxidation ('anammox') process. Current Opinion in Biotechnology, 12(3), 283-288. doi: http://dx.doi.org/10.1016/S0958-1669(00)00211-1

Kang, K.-H., Shin, H. S., \& Park, H. (2002). Characterization of humic substances present in landfill leachates with different landfill ages and its implications. Water Research, 36(16), 4023-4032. doi: http://dx.doi.org/10.1016/S0043-1354(02)00114-8

Kjeldsen, P., Barlaz, M. A., Rooker, A. P., Baun, A., Ledin, A., \& Christensen, T. H. (2002). Present and Long-Term Composition of MSW Landfill Leachate: A Review. Critical Reviews in Environmental Science and Technology, 32(4), 297-336. doi: $10.1080 / 10643380290813462$

Knox, K., Braithwaite, P., Caine, M., \& Croft, B. (2005). Brogborough landfill test cells: the final chapter. A study of landfill completion in relation to final storage quality (FSQ) criteria. Paper presented at the International Waste Management and Landfill Symposium, Sardinia, Italy.

Komilis, D. P., \& Ham, R. K. (2003). The effect of lignin and sugars to the aerobic decomposition of solid wastes. Waste Management, 23(5), 419-423. doi: http://dx.doi.org/10.1016/S0956-053X(03)00062-X

Laner, D., Crest, M., Scharff, H., Morris, J. W. F., \& Barlaz, M. A. (2012). A review of approaches for the long-term management of municipal solid waste landfills. Waste Management, 32(3), 498-512. doi: http://dx.doi.org/10.1016/j.wasman.2011.11.010

Owens, J. M., \& Chynoweth, D. P. (1992). Biochemical Methane Potential of MSW Components Paper presented at the International Symposium on Anaerobic digestion of Solid Waste.

Raga, R., \& Cossu, R. (2013). Bioreactor tests preliminary to landfill in situ aeration: A case study. Waste Management, 33(4), 871-880. doi: http://dx.doi.org/10.1016/j.wasman.2012.11.014

Read, A. D., Hudgins, M., \& Phillips, P. (2001). Perpetual landfilling through aeration of the waste mass; lessons from test cells in Georgia (USA). Waste Management, 21(7), 617629. doi: http://dx.doi.org/10.1016/S0956-053X(00)00124-0

Ritzkowski, M., Heyer, K. U., \& Stegmann, R. (2006). Fundamental processes and implications during in situ aeration of old landfills. Waste Management, 26(4), 356-372. doi: http://dx.doi.org/10.1016/j.wasman.2005.11.009

Scharff, H. (2010). Landfill Closure, Aftercare and Final Use Solid Waste Technology \& Management (pp. 932-947): John Wiley \& Sons, Ltd.

Scharff, H. (2014). Landfill reduction experience in The Netherlands. Waste Management, 34(11), 2218-2224. doi: http://dx.doi.org/10.1016/j.wasman.2014.05.019

Stegmann, R., Heyer, K. U., Hupe, K., \& Ritzkowski, M. (2003). Discussion of Criteria for the Completion of Landfill Aftercare. Paper presented at the Sardinia International Waste Management and Landfill Symposium, Sardinia, Italy.

Tchobanoglous, G., \& Kreith, F. (2002). Handbook of solid waste management McGraw-Hill's AccessEngineering (pp. 1 online resource). Retrieved from http://www.loc.gov/catdir/toc/mh031/2002021284.html

http://www.loc.gov/catdir/bios/mh041/2002021284.html

http://accessengineeringlibrary.com/browse/handbook-of-solid-waste-management-secondedition 
Tuomela, M., Vikman, M., Hatakka, A., \& Itävaara, M. (2000). Biodegradation of lignin in a compost environment: a review. Bioresource Technology, 72(2), 169-183. doi: http://dx.doi.org/10.1016/S0960-8524(99)00104-2

Valencia, R., van der Zon, W., Woelders, H., Lubberding, H. J., \& Gijzen, H. J. (2009). Achieving "Final Storage Quality" of municipal solid waste in pilot scale bioreactor landfills. Waste Management, 29(1), 78-85. doi: http://dx.doi.org/10.1016/j.wasman.2008.02.008

Wang, X., Padgett, J. M., De la Cruz, F. B., \& Barlaz, M. A. (2011). Wood Biodegradation in Laboratory-Scale Landfills. Environmental Science \& Technology, 45(16), 6864-6871. doi: 10.1021/es201241g

Wang, X., Padgett, J. M., Powell, J. S., \& Barlaz, M. A. (2013). Decomposition of forest products buried in landfills. Waste Management, 33(11), 2267-2276. doi: http://dx.doi.org/10.1016/j.wasman.2013.07.009

Worrell, W. A., Reinhart, D. R., \& Vesilind, P. A. (2002). Solid waste engineering. United Kingdom: Brooks $\backslash$ Cole.

Zheng, W., Lü, F., Bolyard, S. C., Shao, L., Reinhart, D. R., \& He, P. (2015). Evaluation of monitoring indicators for the post-closure care of a landfill for MSW characterized with low lignin content. Waste Management, 36(0), 222-229. doi: http://dx.doi.org/10.1016/j.wasman.2014.10.031

Zhong, Q., Li, D., Tao, Y., Wang, X., He, X., Zhang, J., . . Wang, L. (2009). Nitrogen removal from landfill leachate via ex situ nitrification and sequential in situ denitrification. Waste Management, 29(4), 1347-1353. doi: http://dx.doi.org/10.1016/j.wasman.2008.10.014 


\title{
CHAPTER 4
}

\section{CONVENTIONAL AND FOURIER TRANSFORM INFRARED CHARACTERIZATION OF WASTE DURING MUNICIPAL SOLID WASTE STABILIZATION}

\begin{abstract}
$\underline{\text { Abstract }}$
Solid waste and leachate samples from the anaerobic bioreactors and FBs were characterized using Fourier Transform Infrared (FTIR) to provide a better understanding of changes in waste characteristics when waste transitions from mature to stabilized. Organic functional groups associated with aliphatic methylene were present in leachate and solid waste samples during the early stages of anaerobic degradation and disappeared once these wastes underwent treatment. Once the waste was stabilized, the FTIR spectra of leachate and solid waste were dominated by inorganic functional groups (carboxylic acid/carbonate group, carbonate, quartz, and clay minerals).
\end{abstract}

\section{Introduction}

Characterizing and better understanding changes in the organic fraction of solid waste during the degradation process are imperative to evaluate the remaining pollution potential (i.e., gas and leachate emissions) and overall stability of landfilled waste. Ultimately, the goal is to reach complete stabilization before a landfill is released from post-closure care. Complete stabilization of waste is the point at which a landfill, without active care and regulatory oversight, no longer poses a threat to the environment (Morris and Barlaz, 2011) Identifying this point in landfill operation is challenging because little is known regarding the acceptable final storage quality of the solid waste residuals and the extent of waste stabilization that has occurred within a closed 
landfill. Typically leachate characteristics are used as indicators of the extent of waste stabilization because of the ease of sampling.

To date, the changes in the organic fraction of solid waste during the degradation process have been assessed through indicators such as the concentration of cellulose, hemicellulose or lignin; the ratio of cellulose to lignin $(\mathrm{C} / \mathrm{L})$; or the ratio of cellulose plus hemicellulose to lignin (Wang et al., 2013). Other more traditional indicators of biological stability are waste biochemical methane potential (BMP) (Owen et al., 1979; Owens and Chynoweth, 1992) or leachate characterization such as $\mathrm{pH}$, organic carbon, respiration activity, humic acid (HA) evolution, biochemical oxygen demand (BOD) to chemical oxygen demand (COD) ratio, volatile solids (VS), carbon to nitrogen ratio, and the presence of nitrogen compounds; however these analyses tend to be nonspecific, time consuming, and destructive (i.e., samples cannot be reused or are altered) (Castaldi et al., 2005; Chefetz et al., 1998; González-Vila et al., 1999; Lguirati et al., 2005; Reinhart and Townsend, 1998; Smidt et al., 2005; Smidt et al., 2002; Wu et al., 2010).

Alternative methods have grown in popularity as ways to better understand and further analyze the extent of decomposition of waste components (Smidt et al., 2002; Smidt et al., 2005). This chapter focuses on advanced analytical techniques such as Fourier Transform Infrared spectroscopy (FTIR) to characterize solid waste and leachate. Advantages of FTIR are that the technique is quick, nondestructive, and no sample preparation is necessary if using an instrument fitted with an attenuated total reflectance (ATR) tool. Extracted humic acid (HA) will be characterized using $\mathrm{C}^{13}$ Nuclear Magnetic Resonance (NMR). NMR requires a homogenous sample and can be time consuming due to the complexity of HA but offers additional information to compliment FTIR data. 
This chapter will evaluate the extent of waste stabilization based on spectroscopic data from solid waste, leachate, and extracted HA of waste under various treatment approaches. These data will be correlated to conventional solid waste and leachate biochemical parameters. Principal component analysis (PCA) of FTIR data will be used to identify the changes in functional groups that occur under various treatment processes. Functional groups represent specific groups of atoms and bonds within molecules that are responsible for the characteristic chemical reactions of those molecules (Hanson, 2001). This information will be used to provide better insight into what happens when mature waste becomes stable. Spectroscopic stabilization indicators for both leachate and solid waste will also be described.

\section{$\underline{\text { Materials and Methods }}$}

In this study synthetic waste was generated from new and post-consumer products to minimize variability in reactor operation that could result from using "real" waste and also to better define and understand the reactor inputs (Bolyard and Reinhart, 2016). The composition of the synthetic waste is outlined in Table 4-1 and is representative of municipal solid waste (MSW) generated in Florida. A detailed breakdown of new and post-consumer products used for each category is provided in Appendix C (Table C-1). 
Table 4-1. Anaerobic Bioreactor Waste Composition

\begin{tabular}{|c|c|}
\hline Components & $\begin{array}{c}\text { Anaerobic Bioreactor (\% by weight; } \\
\text { dry) }\end{array}$ \\
\hline Food Waste & 9.0 \\
\hline Plastics & 7.0 \\
\hline Tires & 1.0 \\
\hline Other Paper & 30 \\
\hline Glass & 0 \\
\hline Metals & 12 \\
\hline Textiles & 4.0 \\
\hline Yard Trash & 17 \\
\hline Newspapers & 7.0 \\
\hline Miscellaneous & 13 \\
\hline
\end{tabular}

Laboratory-scale anaerobic bioreactors were constructed to simulate anaerobic degradation of the synthetic waste (Figure 4-1). Reactors were filled with synthetic MSW ( 24.9 kg per reactor).

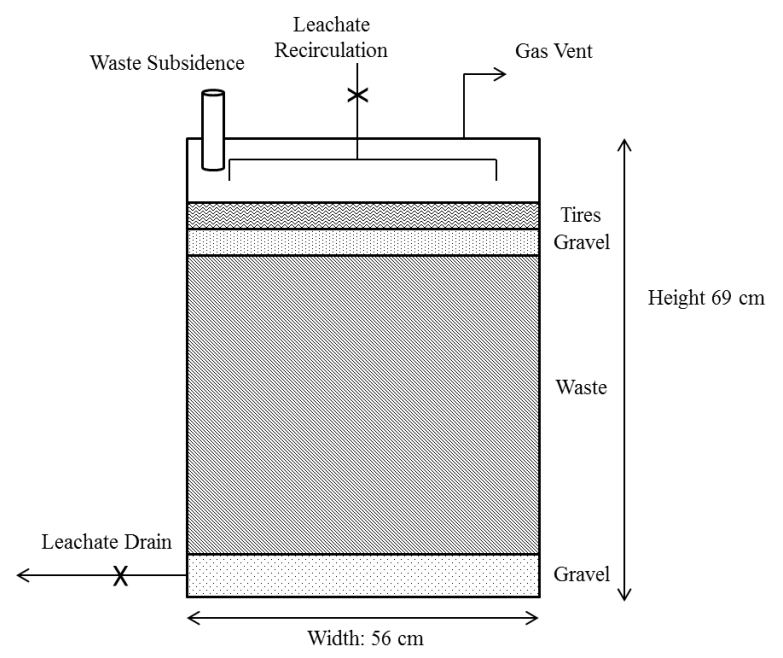

Figure 4-1. Laboratory-Scale Anaerobic Bioreactor Schematic

Leachate was introduced through a perforated polyvinyl chloride pipe grid placed under the reactor lid, ensuring equitable distribution of leachate. Approximately $1.5 \mathrm{~L}$ of buffered (2,000 $\mathrm{mg} / \mathrm{L}$ of sodium bicarbonate) DI water were initially added every three days to each reactor to generate a sufficient volume of leachate to be recirculated. Once approximately $2 \mathrm{~L}$ of leachate 
were generated, reactors were drained and leachate was recirculated every three days. During this time leachate samples were collected from each reactor every two weeks and analyzed prior to recirculation. The reactors provided a source of mature waste for subsequent treatment (i.e., five-day biochemical oxygen demand/chemical oxygen demand $\left.\left(\mathrm{BOD}_{5} / \mathrm{COD}\right)<0.10\right)$.

The mature waste from the laboratory-scale anaerobic bioreactors was further treated under three flushing bioreactor (FB) scenarios, (1) flushing with clean water (FB 1), (2) recirculation of leachate, external leachate oxidation using Fenton's Reagent, with no internal oxidation (FB 2), and (3) recirculation of leachate and external leachate oxidation using Fenton's Reagent and internal aeration (FB 3), depicted in Figure 4-2. FB 3 was operated under "semi-aerobic" conditions since only the upper portion of the waste in FB 3 was aerated with the goal of facilitating conditions for nitrification and denitrification. Additional details of the operation of these reactors can be found in Bolyard and Reinhart (2016).

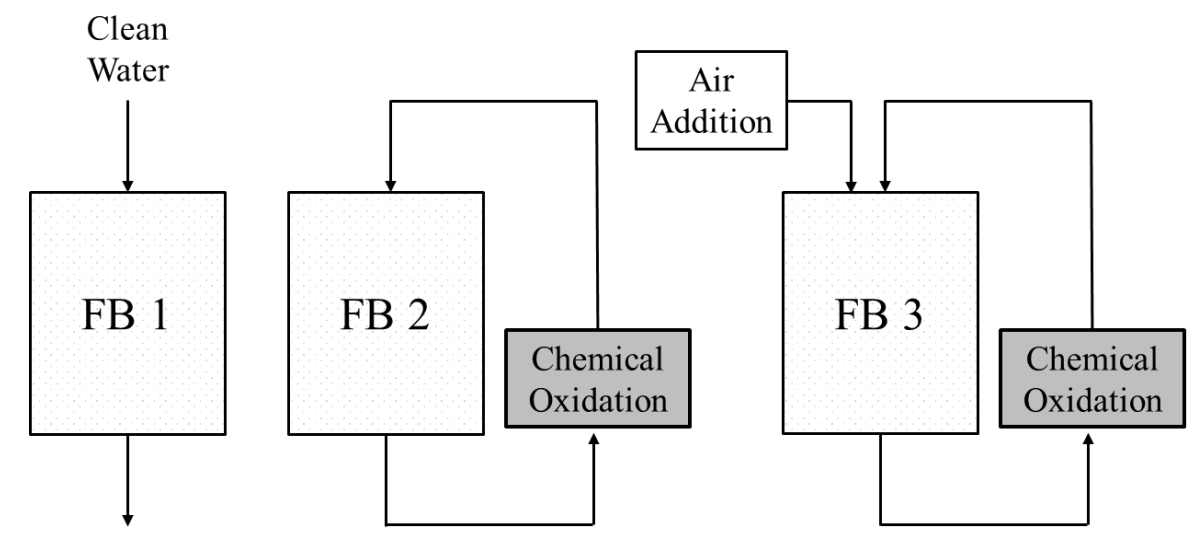

Figure 4-2. Simplified Illustration of Flushing Bioreactor Operation (Bolyard and Reinhart, 2016) 


\section{Sample Characterization}

Waste and leachate samples removed periodically from the laboratory-scale anaerobic bioreactors and FBs were characterized using both conventional and spectroscopic techniques, as outlined in Bolyard and Reinhart (2016). The initial synthetic waste was also characterized using the same techniques. Conventional techniques for leachate characterization include $\mathrm{COD}, \mathrm{BOD}_{5}$, ammonia-nitrogen, nitrate-nitrogen, and nitrite-nitrogen following the Standard Methods for the Examination of Water and Wastewater (APHA, 2005). The dissolved humic HA concentration was determined by measuring the UV absorbance at $254 \mathrm{~nm}$ of a sample filtered through a 0.45 $\mu \mathrm{m}$ filter. The concentration was then calculated from a standard curve developed from a stock solution made from Aldrich HA (Bolyard et al., 2013). The absorbance at $465 \mathrm{~nm}\left(\mathrm{E}_{4}\right)$ and 665 $\mathrm{nm}\left(\mathrm{E}_{6}\right)$ was measured and their ratio to determine the degree of humification of the leachate organic matter (Amir et al., 2003; Domeizel et al., 2004; Fukushima et al., 2009; Rivero et al., 2004).

Waste samples were characterized for moisture content; biodegradable VS; carbon, nitrogen, C, H, and L content; and BMP (following procedures in Owens and Chynoweth (1992)). Details of these methods can be found in Bolyard and Reinhart (2016). Plastics, tire pieces, rope, and other non-biodegradable but ignitable components at $550^{\circ} \mathrm{C}$ were removed prior to heating the samples to determine the biodegradable VS fraction. 


\section{Humic Acid Extraction from Solid Waste}

The evolution (production) of HA has been an indicator of the extent of waste stabilization in landfills, composting, and wastewater sludge processing (Nanny and Ratasuk, 2002). The evolution of HA is evaluated by determining the change in concentration and the extent of humification using spectral properties. The HA concentration has been shown to increase as waste is stabilized. HA was extracted from solid waste samples as one indicator of stabilization for each FB scenario. The extraction procedure is based on a modified method to isolate HA and fulvic acid (FA) from solid-phase materials (IHSS, 2007).

Twenty grams of the milled waste samples were placed in a 500-mL Erlenmeyer flask and the $\mathrm{pH}$ was equilibrated to 2.0 S.U. with $1 \mathrm{M} \mathrm{HCl}$ at room temperature $\left(\sim 24^{\circ} \mathrm{C}\right)$. The final volume was adjusted to a volume to solids ratio of $10 \mathrm{~mL}$ of liquid per $1.0 \mathrm{~g}$ of solid waste with 0.1 M HCl. Each flask was placed on a shaker table, at $200 \mathrm{RPM}$, for approximately one hour. Each suspension was decanted for 30 minutes to separate the FA (supernatant) and HA (residue) fractions. Supernatant was discarded after decanting since the focus of this study was to look at $\mathrm{HA}$ as an indicator of waste stability. The residue was neutralized with $1 \mathrm{M} \mathrm{NaOH}$ to a $\mathrm{pH}$ of 7.0 S.U. followed by the addition of $0.1 \mathrm{M} \mathrm{NaOH}$ for 10:1 final extractant to residue ratio. This neutralized fraction was shaken every 15 minutes for approximately four hours. The solution was then allowed to settle overnight, centrifuged (4000 RPM for 10 minutes), and the supernatant was collected (HA). In order to precipitate out the HA fraction, the supernatant was acidified with $6 \mathrm{M} \mathrm{HCl}$ (final $\mathrm{pH}$ of 1.0 S.U.), under continuous shaking, after which the suspension was allowed to settle for approximately 12 to 16 hours. The HA fraction was collected and suspended in a minimal volume of DI water. The HA suspension was dialyzed against DI water using prewetted dialysis tubing with a 1,000 dalton molecular weight cut-off (Spectrums Lab \#132640) 
for a 48-hour period (DI was replaced after 24 hours). The final HA extraction was dried overnight at $105^{\circ} \mathrm{C}$ and placed in a desiccator for further analysis.

\section{Characterization of Solid Waste and Leachate Using Fourier Transform Infrared Spectroscopy}

Dried leachate and solid waste were analyzed using a Perkin Elmer Spectrum 100 Series FTIR equipped with a diamond ATR device. At least three spectra were acquired for each sample $\left(4,000 \mathrm{~cm}^{-1}\right.$ to $\left.650 \mathrm{~cm}^{-1}\right)$. Functional group transmittance peaks were identified based on published assignments for FTIR spectral peaks of leachate and solid waste (Smidt et al., 2005, Socrates, 2001, Hajjouji et al., 2008, Kang et al., 2002, He et al., 2010, Piccolo et al., 1992, Tseng et al., 1996, Ouatmane et al., 2000, Naumann et al., 1996, Hesse et al., 1995, Madejova, 2003, Grube et al., 1999, Nanny and Ratasuk, 2002, Faix, 1991, Smith, 1999, Bosch et al., 2002, Smidth and Schwanninger, 2007, Castaldi et al., 2005, Hafidi et al., 2005). PCA was used to further understand the variance in the acquired data by identifying patterns in waste and leachate FTIR data sets to highlight differences and similarities (Smidt and Schwanninger, 2007; Smidt et al., 2002). Unscrambler X (CAMO Software) was used to perform PCA. All spectra were normalized and baseline-corrected prior to analysis. PCA of the spectra were normalized by mean centering (i.e., data brought around the origin). Score and loading plots were generated for each analysis. Score plots display the position of each sample relative to PCs 1 and 2. PCs are groups of uncorrelated variables generated from a larger correlated data set. Each PC is then

described by multiple functional groups detected in the FTIR spectra. Loading plots are then used to explain how the variables are related to each other for each PC. 
Extracted Humic Acid Characterization using ${ }^{13} \mathrm{C}$ Nuclear Magnetic Resonance

A NMR ${ }^{13} \mathrm{C}$ spectrum of the extracted HA was acquired using a $500 \mathrm{MHz}$ Varian VNMRS. Dried HA was dissolved in $2.0 \mathrm{~mL}$ of deuterium oxide $\left(\mathrm{D}_{2} \mathrm{O}\right)$ and $\mathrm{NaOH}(1.0 \mathrm{~N})$ then filtered through a $0.45-\mu \mathrm{m}$ filter to remove any particulate matter. Due to the low sensitivity of ${ }^{13} \mathrm{C}$, each spectrum was acquired for at least 24 hours to adequately resolve all chemical shifts. Water suppression reduced the intensity of the water $\left(\mathrm{D}_{2} \mathrm{O}\right)$ shift at 4.66 parts per million (ppm) to allow for peaks of lower intensity to be identified. Each spectrum was acquired through 115,000 scans with a 1-second acquisition time, a 1-second recycle delay, and a pulse of 45 degrees. Prior to analysis each spectrum was processed by applying a $30 \mathrm{~Hz}$ linebroading and baseline correction.

\section{$\underline{\text { Results and Discussion }}$}

\section{Conventional Solid Waste and Leachate Characterization}

Synthetic waste generated in this study underwent the treatments outlined in Figure 4-3. The extent of treatment was normalized by a liquid to solids $(\mathrm{L} / \mathrm{S})$ ratio. $\mathrm{L} / \mathrm{S}$ is the ratio of cumulative volume of clean or treated liquid added per mass of initial dry waste.

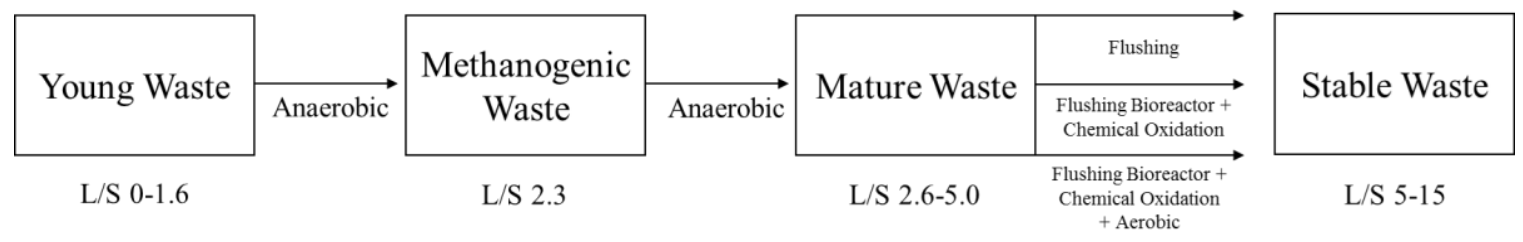

Figure 4-3. Overview of Waste Treatments

During anaerobic digestion of the young waste, the biodegradable VS fraction declined by approximately $52 \%$ as of a L/S of 5.0 (Bolyard and Reinhart, 2016). The mature waste was further treated under the three FB scenarios. The volatile solids declined by approximately $22 \%$ 
in FBs 1 and 3 and 23\% for FB 2 relative to the mature waste (Table 3-2 and Figure C-1). At the end of treatment (L/S of 15) the overall reduction of the volatile solids fraction in FBs was $74 \%$ $75 \%$.

Table 4-2. Summary of Mature and Flushing Bioreactor Waste Characteristics (Bolyard and Reinhart, 2016)

\begin{tabular}{|c|c|c|c|c|c|}
\hline & $\begin{array}{l}\text { Initial } \\
\text { Waste }\end{array}$ & $\begin{array}{l}\text { Mature } \\
\text { Waste }\end{array}$ & $\mathrm{FB} 1^{\mathrm{a}}$ & $\mathrm{FB} 2^{\mathrm{a}}$ & $\mathrm{FB} 3^{\mathrm{a}}$ \\
\hline Moisture Content ( $\%$ by weight) & $46 \%$ & $61 \%$ & $63 \%$ & $62 \%$ & $37 \%$ \\
\hline $\begin{array}{c}\text { Biodegradable Solids (\% by } \\
\text { weight) }\end{array}$ & $65 \%$ & $31 \%$ & $24 \%$ & $25 \%$ & $28 \%$ \\
\hline Cellulose $^{\mathrm{b}}$ & 0.478 & 0.295 & 0.064 & 0.109 & 0.058 \\
\hline Hemicellulose $^{\mathrm{c}}$ & 0.126 & 0.098 & 0.035 & 0.053 & 0.028 \\
\hline Lignin $^{\mathrm{d}}$ & 0.126 & 0.251 & 0.194 & 0.232 & 0.0925 \\
\hline Carbon $^{\mathrm{e}}$ & 0.388 & 0.336 & 0.1638 & 0.2581 & 0.1744 \\
\hline Nitrogen $^{f}$ & 0.0029 & 0.008 & 0.0068 & 0.0089 & 0.0063 \\
\hline $\mathrm{C} / \mathrm{N}$ (unitless) & 136 & 39 & 24 & 29 & 28 \\
\hline$(\mathrm{C}+\mathrm{H}) / \mathrm{L}$ (unitless) & 4.8 & 2.2 & 1.3 & 1.3 & 2 \\
\hline C/L (unitless) & 3.8 & 1.2 & 0.33 & 0.47 & 0.62 \\
\hline Organic Carbon ${ }^{6}(\%$ by weight $)$ & 0.78 & 0.36 & $18 \%$ & $16 \%$ & $19 \%$ \\
\hline BMP $\left(\mathrm{m}^{3} / \mathrm{Mg}\right.$ of dry waste $)$ & 140 & 47 & 10 & 20 & 31 \\
\hline
\end{tabular}

a. $\mathrm{L} / \mathrm{S}$ of 15

b. g cellulose/g dry wt. of biodegradable fraction

c. g hemicellulose/g dry wt. of biodegradable fraction

d. g lignin/g dry wt. of biodegradable fraction

e. g carbon/g dry wt. of biodegradable fraction

f. g nitrogen/g dry wt. of biodegradable fraction

g. g organic carbon/g dry wt. of biodegradable fraction

Under anaerobic conditions cellulose is degraded while lignin is recalcitrant, therefore the $\mathrm{C} / \mathrm{L}$ decreases as waste is degraded; the $\mathrm{C} / \mathrm{L}$ of the initial waste decreased from 3.8 to 1.2 by a $\mathrm{L} / \mathrm{S}$ of 5.0. Furthermore, the methane potential of the waste samples decreased significantly during anaerobic treatment (66\% reduction; Table 4-2 and Figure 3-4). Because FBs 1 and 2 were operated under anaerobic conditions, a decrease in this ratio was confirmed that cellulose was degraded and lignin enrichment occurred as would be expected (Figure 4-5). An increase in 
$\mathrm{C} / \mathrm{L}$ was observed in FB 3 which can be attributed to the partial degradation of lignin under semi-aerobic conditions (Table D-2 and Figure 3-3).

There was also a significant decrease in the methane potential of the waste removed from the FBs relative to the mature waste (Table D-2 and Figure C-4). The higher methane potential for FB 3 waste compared to FBs 1 and 2 at L/S of 15 was attributed to the higher C/L and that cellulose may have been more available during the optimized BMP test due to the partial degradation of lignin under semi-aerobic conditions.

Leachate collected from the anaerobic bioreactors followed the typical acidogenic, methanogenic, and mature phase trends for $\mathrm{pH}, \mathrm{COD}, \mathrm{BOD}_{5}$, and ammonia-N (Table 4-3). Figure 4 summarizes the concentration of COD and HA in the anaerobic bioreactors. The steepness of the COD curve during anaerobic degradation shows that the organic matter was effectively converted to methane and carbon dioxide between a L/S of 1.5-3.0 (Figure 4-10). The increase in HA mirrored the COD decrease observed during anaerobic treatment. Figures C-1 through $\mathrm{C}-4$ show detailed trends for $\mathrm{pH}, \mathrm{COD}, \mathrm{BOD}_{5}$, and ammonia-N. Although the $\mathrm{BOD}_{5} / \mathrm{COD}$ was well below 0.10 , the COD, ammonia-N, and HA concentrations remained high. 
Table 4-3. Characteristics of the Acidogenic, Methanogenic, and Mature Leachate from the Laboratory-Scale Anaerobic Bioreactors*

\begin{tabular}{|c|c|c|c|}
\hline Parameter & Acidogenic & Methanogenic & $\begin{array}{c}\text { Mature } \\
\text { Leachate }\end{array}$ \\
\hline pH (S.U.) & 5.28 & 7.23 & 7.60 \\
\hline $\mathrm{COD}(\mathrm{mg} / \mathrm{L})$ & 53,400 & 37,600 & 5,350 \\
\hline $\mathrm{BOD}_{5}(\mathrm{mg} / \mathrm{L})$ & 41,900 & 15,750 & 161 \\
\hline $\mathrm{BOD}_{5} / \mathrm{COD}$ & 0.78 & 0.42 & 0.03 \\
\hline $\begin{array}{c}\text { Ammonia-Nitrogen } \\
(\mathrm{mg} / \mathrm{L})\end{array}$ & 196 & 320 & 472 \\
\hline Humic Acid (mg/L) & 312 & 356 & 1,200 \\
\hline
\end{tabular}

* Prior to FB treatment
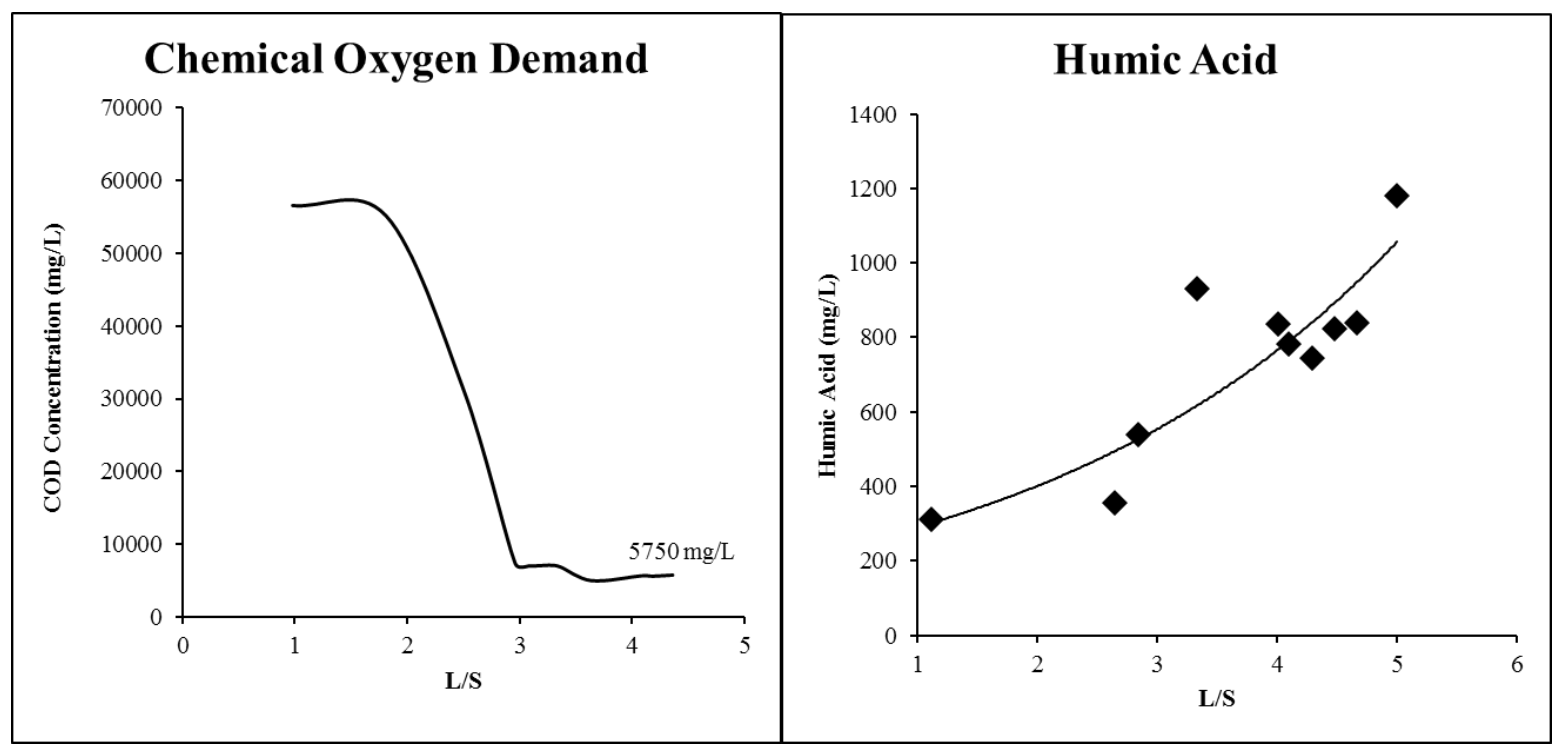

Figure 4-4. Chemical Oxygen Demand and Humic Acid Concentrations from Laboratory-Scale Anaerobic Bioreactors

Leachate quality improved for all FB treatments compared to the anaerobic bioreactor (Table 4-4) but through different mechanisms. A significant reduction in ammonia-nitrogen occurred in FB 1 and 3 due to flushing and aeration, respectively. The minor reduction in ammonia-nitrogen for FB 2 was due to sorption (Bolyard and Reinhart, 2016). The reduction of COD in FB 1 was primarily due to flushing. Conversely, the reduction in COD in FBs 2 and 3 was due to oxidation and precipitation during Fenton's Reagent treatment. FB 3 had a higher final COD concentration 
relative to FBs 1 and 2. The higher concentration of COD could be a result of leachate evaporation of leachate during in-situ aeration (Read et al., 2001), lignin degradation, or the production of HA under semi-aerobic conditions.

Table 4-4. Characteristics of the Mature and FB Leachate (Bolyard and Reinhart, 2016)

\begin{tabular}{|c|c|c|c|c|}
\hline Parameter & $\begin{array}{c}\text { Mature } \\
\text { Leachate }\end{array}$ & FB $1^{*}$ & FB 2* & FB 3* \\
\hline $\mathrm{pH}(\mathrm{S} . \mathrm{U})$. & 7.60 & 6.50 & 7.40 & 8.10 \\
\hline $\mathrm{COD}^{(\mathrm{mg} / \mathrm{L})}$ & 5,350 & 150 & 347 & 1250 \\
\hline $\mathrm{BOD}_{5}(\mathrm{mg} / \mathrm{L})$ & 161 & 9 & 23.5 & 3 \\
\hline $\mathrm{BOD}_{5} / \mathrm{COD}$ & 0.03 & 0.060 & 0.068 & 0.0024 \\
\hline $\begin{array}{c}\text { Ammonia-Nitrogen } \\
(\mathrm{mg} / \mathrm{L})\end{array}$ & 472 & 6.6 & 129 & 0.45 \\
\hline Humic Acid (mg/L) & 1,200 & 45.1 & 57.1 & 661 \\
$*$ L/S of 15
\end{tabular}

As shown in Table 4-4 there were significant changes in COD, ammonia-N, and HA concentrations during FB treatment, which occurred primarily from L/S 5.0 to 8.0. Leachate quality is the most commonly used indicator of landfill stability but may not provide a comprehensive picture of the extent of stabilization. The $\mathrm{BOD}_{5} / \mathrm{COD}$ ratio of FBs 1 and 2 did not change significantly despite the further treatment of the mature waste in the FBs (Figure 4-5). However $\mathrm{BOD}_{5} / \mathrm{COD}$ ratio in $\mathrm{FB} 3$ decreased significantly (0.03 to 0.0024$)$ as a result of the decrease in $\mathrm{BOD}_{5}$ from aerobic biodegradation and higher change in HA concentrations (Figure 4-4). 


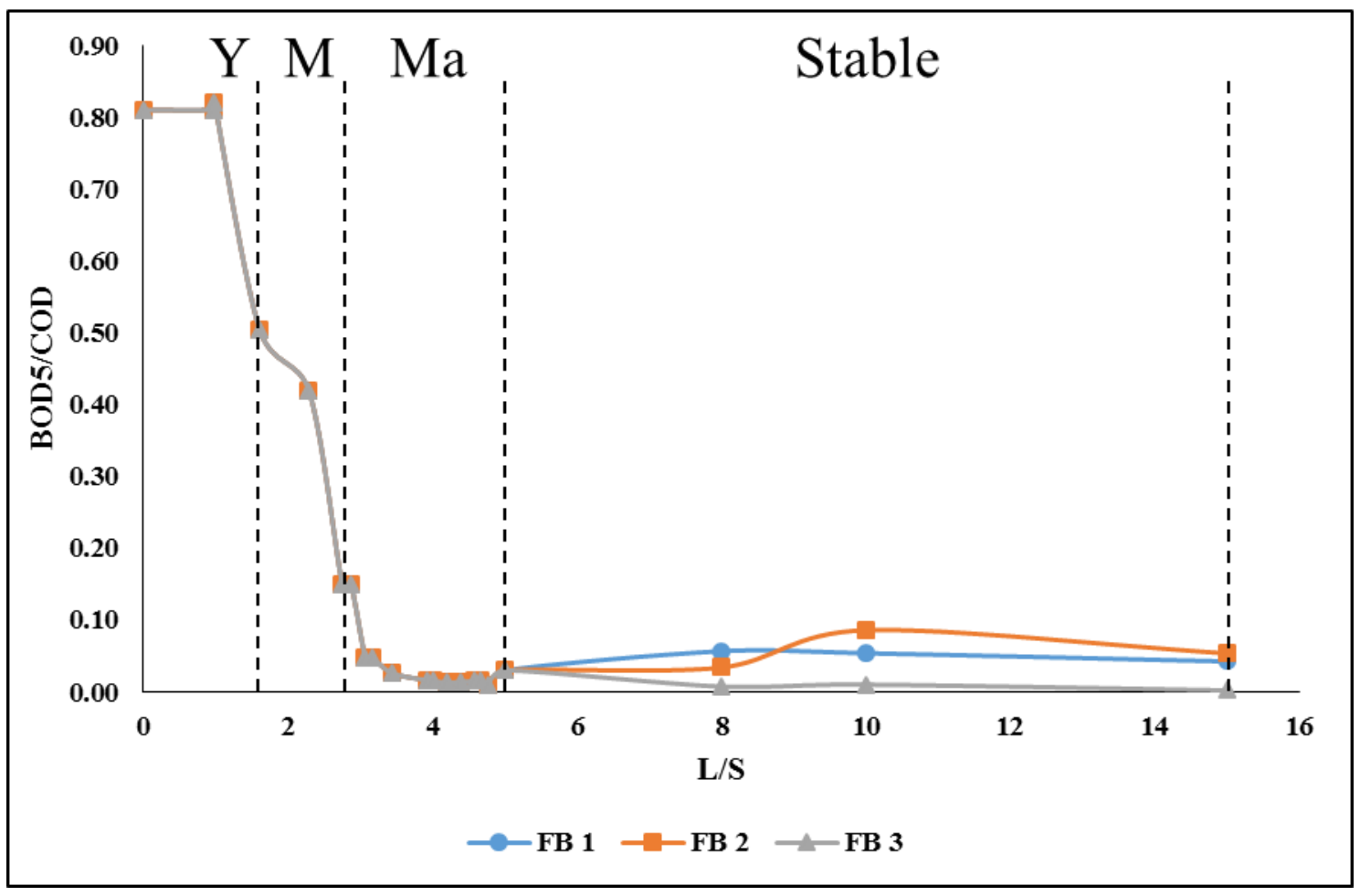

Figure 4-5. BOD 5 /COD Ratio During Waste Treatments and Associated Degradation Phases (Y: Young; M: Methanogenic; Ma: Mature)

FTIR Characterization of Leachate and Solid Waste

FTIR characterization of solid waste and leachate samples shed light on the changes in the functional groups present in these samples that occurred during anaerobic and FB treatment. The spectra acquired for solid waste and leachate consisted of both organic $\left(3,000 \mathrm{~cm}^{-1}\right.$ to $\left.2,000 \mathrm{~cm}^{-1}\right)$ and inorganic $\left(<1,500 \mathrm{~cm}^{-1}\right)$ functional groups. Organic functional groups included aliphatic methylene $\left(2920 \mathrm{~cm}^{-1}\right.$ and $\left.2850 \mathrm{~cm}^{-1}\right)$ and aromatic carbon $\left(2981 \mathrm{~cm}^{-1}\right)$. Inorganic functional groups included carboxylic acid/carbonate group $\left(1420 \mathrm{~cm}^{-1}\right)$, carbonate $\left(875 \mathrm{~cm}^{-1}\right)$, quartz $(1082$ $\left.\mathrm{cm}^{-1}\right)$, and clay minerals $\left(1030 \mathrm{~cm}^{-1}\right)$. FTIR spectra were analyzed using PCA and peak identified using literature values. 


\section{Leachate Characterization}

PCA was performed on leachate data for samples collected from the anaerobic bioreactors at L/S 2.3, 2.6, and 5.0 and FB 1-3 at L/S of 8 and 10 (Figure 4-6). A summary of the peaks identified in these leachate samples is provided in Table 4-5. Figure 4-6 shows the score plot (PC 1 vs. PC 2) for these samples. Loading plots for PCs 1 and 2 are provided in the supplemental information (Figure D-5). Waste degradation progression in the anaerobic bioreactor and FBs 13 leachate was captured by the changes in the PCs. These changes are reflected by the spatial shifts observed for each FB on the score plot. 
Table 4-5. Summary of FTIR Observations for Leachate Samples

\begin{tabular}{|c|c|c|}
\hline Leachate Stability Indicators & Wavenumber & Functional Group \\
\hline \multirow{3}{*}{ Anaerobic Bioreactor ${ }^{\mathrm{a}}$} & 2920 and $2850 \mathrm{~cm}^{-1}$ & Aliphatic Methylene \\
\hline & $1420 \mathrm{~cm}^{-1}$ & $\begin{array}{c}\text { Carboxylic Acid, Carbonate (COO- } \\
\text { Stretch) }\end{array}$ \\
\hline & $875 \mathrm{~cm}^{-1}$ & Carbonate \\
\hline \multirow{3}{*}{ Mature Waste ${ }^{\mathrm{b}}$} & $1420 \mathrm{~cm}^{-1}$ & $\begin{array}{c}\text { Carboxylic Acid, Carbonate (COO- } \\
\text { Stretch) }\end{array}$ \\
\hline & $1447 \mathrm{~cm}^{-1}$ & Inorganic Compounds \\
\hline & $875 \mathrm{~cm}^{-1}$ & Carbonate \\
\hline \multirow{3}{*}{ Flushing Bioreactor $1^{\mathrm{c}}$} & $1420 \mathrm{~cm}^{-1}$ & $\begin{array}{c}\text { Carboxylic Acid, Carbonate (COO- } \\
\text { Stretch) }\end{array}$ \\
\hline & $1030 \mathrm{~cm}^{-1}$ & Inorganics \\
\hline & $875 \mathrm{~cm}^{-1}$ & Carbonate \\
\hline \multirow{3}{*}{ Flushing Bioreactor $2^{\mathrm{c}}$} & $2920 \mathrm{~cm}^{-1}$ and $2850 \mathrm{~cm}^{-1}$ & Aliphatic Methylene \\
\hline & $2981 \mathrm{~cm}^{-1}$ & Aromatic Carbon $(\mathrm{C}=\mathrm{C})$ \\
\hline & $1420 \mathrm{~cm}^{-1}$ & $\begin{array}{c}\text { Carboxylic Acid, Carbonate (COO- } \\
\text { Stretch) }\end{array}$ \\
\hline \multirow{3}{*}{ Flushing Bioreactor $3^{\mathrm{c}}$} & $2981 \mathrm{~cm}^{-1}$ & Aromatic Carbon $(\mathrm{C}=\mathrm{C})$ \\
\hline & $2920 \mathrm{~cm}^{-1}$ and $2850 \mathrm{~cm}^{-1}$ & Aliphatic Methylene \\
\hline & $1420 \mathrm{~cm}^{-1}$ & $\begin{array}{c}\text { Carboxylic Acid, Carbonate (COO- } \\
\text { Stretch) }\end{array}$ \\
\hline
\end{tabular}
a. $\mathrm{L} / \mathrm{S}$ of 2.3
b. $\mathrm{L} / \mathrm{S}$ of 5
c. $\mathrm{L} / \mathrm{S}$ of 15 


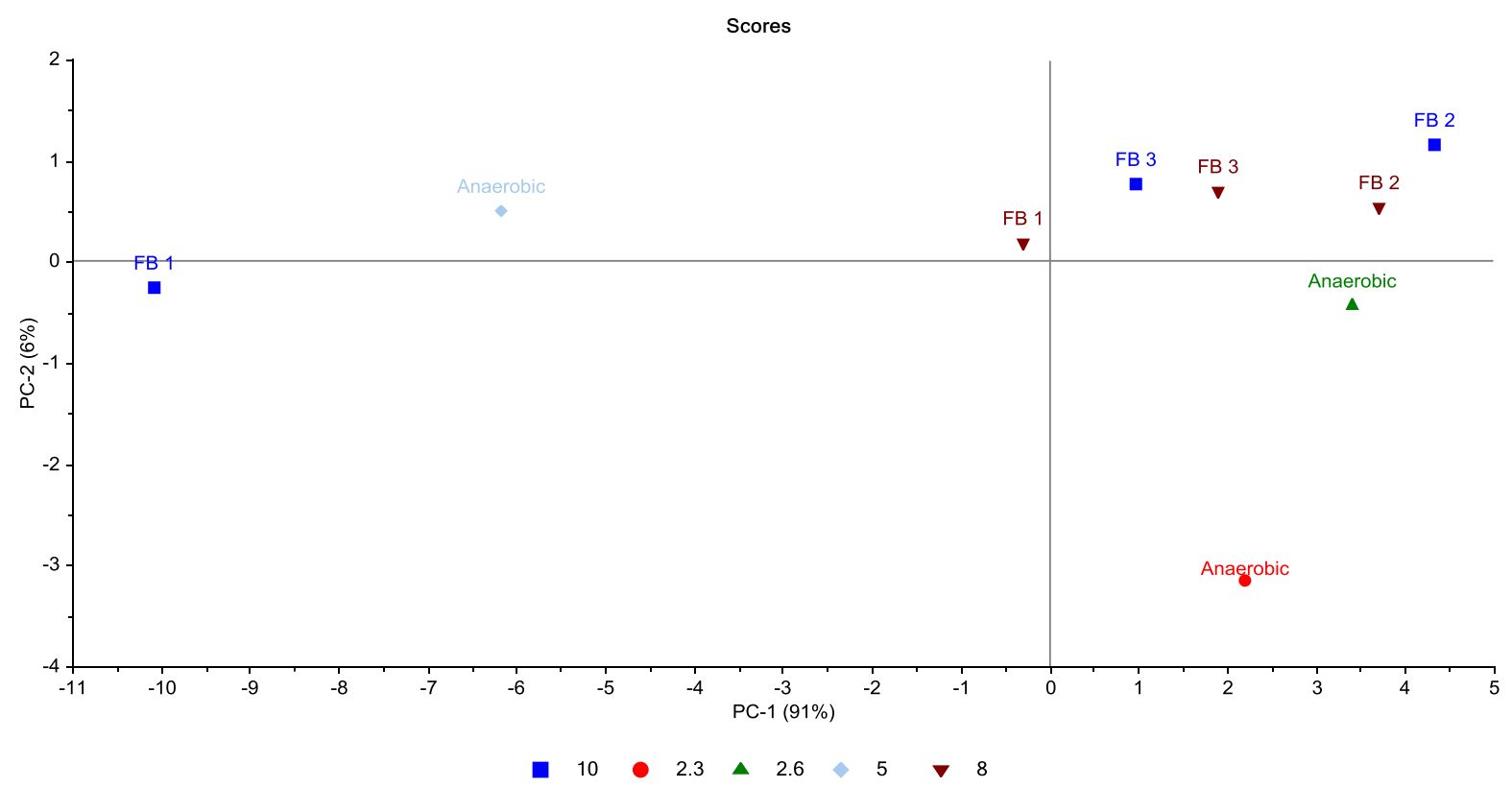

Figure 4-6. PCA Scores Plot of FTIR Spectrum of Anaerobic Bioreactor and FBs 1-3 (L/S of 810) Leachates

Table 4-6. Summary of Loadings Associated with Principal Components 1 and 2

\begin{tabular}{|c|c|c|c|c|c|}
\hline \multicolumn{2}{|c|}{ PC 1 (+) } & \multicolumn{2}{|c|}{ PC 2(+) } & \multicolumn{2}{c|}{ PC 2 (-) } \\
\hline Wavenumber & Functional Group & Wavenumber & Functional Group & Wavenumber & $\begin{array}{c}\text { Functional } \\
\text { Group }\end{array}$ \\
\hline $1420 \mathrm{~cm}^{-1}$ & $\begin{array}{c}\text { Carboxylic Acid, } \\
\text { Carbonate (COO- } \\
\text { Stretch) }\end{array}$ & $2931 / 2850 \mathrm{~cm}^{-1}$ & $\begin{array}{c}\text { Aliphatic Methylene } \\
\text { Structures }\end{array}$ & $1082 \mathrm{~cm}^{-1}$ & Quartz \\
\hline $1254 \mathrm{~cm}^{-1}$ & $\begin{array}{c}\text { Carboxylic acids, Amide } \\
\text { III }\end{array}$ & $1740 \mathrm{~cm}^{-1}$ & Carboxylic (C=O) & $1030 \mathrm{~cm}^{-1}$ & Inorganics \\
\hline $1030 \mathrm{~cm}^{-1}$ & Inorganics & $1420 \mathrm{~cm}^{-1}$ & $\begin{array}{c}\text { Carboxylic Acid, } \\
\text { Carbonate (COO- } \\
\text { Stretch) }\end{array}$ & $875 \mathrm{~cm}^{-1}$ & Carbonate \\
\hline $875 \mathrm{~cm}^{-1}$ & Carbonate & $1256 \mathrm{~cm}^{-1}$ & $\begin{array}{c}\text { Carboxylic acids, } \\
\text { Amide III }\end{array}$ & & \\
\hline
\end{tabular}

Changes in the organic functional groups during anaerobic treatment (i.e., aliphatic methylene and aromatic) in the leachate were related to a positive PC 2; this PC captures $6 \%$ of the variance. The changes occurring in the leachate during the acidogenic/methanogenic phases were reflected in the spectra by a decrease in aliphatic methylene functional groups. There was a significant shift from negative PC 2 to positive among the three anaerobic samples and correlated 
with the changes that would be expected as organics are converted to methane and carbon dioxide. This functional group was no longer detected by a L/S of 5.0. This behavior would be expected as these groups are aliphatic and have been shown to decrease in intensity as waste stabilizes (Schmidt et al., 2011).

The anaerobic leachates (L/S of 2.3 and 2.6) were also correlated to a positive PC 1. The loadings associated with a positive PC 1 are summarized in Table 6; this PC captures 91\% of the variance. The functional groups correlated to positive PC 1 are summarized in Table 4-6 were primarily associated with inorganic groups (carboxylic acid, carbonate, and inorganics (i.e., Si-O stretch)). The dominance of these functional groups is attributed to the continued mineralization of organic matter (Smidt et al., 2002). The mature leachate was associated with a negative PC 1. Negative PC 1 is anticorrelated with the functional groups related to positive PC 1, therefore would support an increase in the mature leachate carboxylic acid, carbonate, and inorganic groups ( $\mathrm{Si}-\mathrm{O}$ stretch). The trends observed in the anaerobic leachate align well with characteristics summarized in Table 4-3 (i.e., decrease in COD and increase in HA).

Treatment between a L/S 5.0 and 8.0 showed the most significant changes captured by the shifts spatially from the mature leachate to FBs 1-3 in the score plot (Figure 4-6). Leachate collected from FBs 1 was described by a negative PC 1 and reflected a decrease in inorganic functional groups summarized in Table 4-6 (i.e., positive PC 1). This trend agrees with the decrease in leachate constituents for FB 1 due to flushing. Positive PC 2 was associated with methylene aliphatic and carboxylic acid groups. Leachate FTIR spectra collected from FBs 2 and 3 were associated with these functional groups. The appearance of the aliphatic methylene peak in FBs 2 and 3 can also be from the utilization of Fenton's Reagent to break down complex 
organic matter into less complex structures. However FB 1 and anaerobic bioreactor (L/S of 5.0) FTIR spectra were primarily associated with inorganic functional groups.

An aromatic carbon $(C=C)$ peak was present at $2981 \mathrm{~cm}^{-1}$ at $\mathrm{L} / \mathrm{S}$ of 8 and 15 in $\mathrm{FBs} 2$ and 3. Primary amines (i.e. nitrogen attached to only one carbon) were observed at $\sim 1560 \mathrm{~cm}^{-1}$ in all leachates throughout treatment. Sulfate and nitrate functional groups were present in FB 3 expressed at $1139 \mathrm{~cm}^{-1}(\mathrm{~L} / \mathrm{S}$ of 8$)$ and $1384 \mathrm{~cm}^{-1}$ (L/S of 10), respectively, due to in-situ aeration and were not detected in the anaerobic bioreactors or FBs 1 and 2. Inorganic functional groups were the dominant components present in leachate of all FBs (peaks at $1421 \mathrm{~cm}^{-1}$ (positive PC 2) and $875 \mathrm{~cm}^{-1}$ (positive PC 1 and negative PC 2). A decrease in intensity at $1421 \mathrm{~cm}^{-1}$ occurred as the $\mathrm{L} / \mathrm{S}$ increased for FBs 2 and 3. The peak at $875 \mathrm{~cm}^{-1}$ disappeared at $\mathrm{L} / \mathrm{S}$ of 15 , which was also observed in FB 2. The carbonate peak at $875 \mathrm{~cm}^{-1}$ disappeared by L/S of 15, most likely due to Fenton's Reagent treatment in FB 2, as carbonates will react with hydroxyl free radicals. This peak also decreased in intensity in FB 3 by the end of treatment, as carbonates disappeared/decreased because of the use of Fenton's Reagent.

Aliphatic methylene peaks $\left(2920 \mathrm{~cm}^{-1}\right.$ and $\left.2850 \mathrm{~cm}^{-1}\right)$ were present in FBs 2 and 3 leachate at L/S of 10 and 15. Presumably the appearance of aliphatic methylene groups was due to the Fenton's Reagent treatment reducing the complexity of the recalcitrant organics (e.g., reduction in the aromaticity and condensation of the organics). This observation was confirmed with the degree of humification of leachate organic matter measured in the leachate by $\mathrm{E}_{4} / \mathrm{E}_{6}$. Typically $\mathrm{E}_{4} / \mathrm{E}_{6}$ below five identifies the emitting organic matter as HA while FAs are characterized by $\mathrm{E}_{4} / \mathrm{E}_{6}$ between six and eight (Fukushima et al., 2009; Amir et al., 2003; Domeizel et al., 2004; Rivero et al., 2004). All $\mathrm{E}_{4} / \mathrm{E}_{6}$ values for $\mathrm{FB}$ leachate organic matter were below five, indicating a dominance of $\mathrm{HA}$ (Table 4-7). FB 1 had a lower $\mathrm{E}_{4} / \mathrm{E}_{6}$ than FBs 2 and 3, suggesting that the 
organic matter was highly aromatic and further stabilized relative to the initial leachate characteristics and to other FBs. FBs 2 and 3 had a different trend as $\mathrm{E}_{4} / \mathrm{E}_{6}$ increased with the length of treatment, suggesting that the organic matter resembled less complex and aromatic organics (i.e. FA). This observation may be due to the addition of Fenton's Reagent as the literature has reported that oxidation by Fenton's Reagent can decrease the aromaticity of the organic matter (Batarseh et al, 2007, Wu et al., 2010, Tekin et al., 2006, Primo et al., 2008, Umar et al., 2010, Deng et al., 2006).

Table 4-7. Degree of Humification of Leachate Organic Matter $\left(\mathrm{E}_{4} / \mathrm{E}_{6}\right)$

\begin{tabular}{|c|c|c|c|c|}
\hline & \multicolumn{4}{|c|}{ Ratio of $\mathrm{E}_{4} / \mathrm{E}_{6}$} \\
\hline & Mature Waste* & L/S of 8 & L/S of 10 & L/S of 15 \\
\hline $\begin{array}{c}\text { Flushing Bioreactor 1 } \\
\text { (Flushing Only) }\end{array}$ & 2.5 & 2.5 & 2.6 & 1.3 \\
\hline $\begin{array}{c}\text { Flushing Bioreactor 2 } \\
\text { (Chemical Oxidation Only) }\end{array}$ & 2.5 & 2.9 & 2.8 & 3.2 \\
\hline $\begin{array}{c}\text { Flushing Bioreactor 3 } \\
\text { (Chemical Oxidation and Aeration) }\end{array}$ & 2.5 & 3.4 & 4.5 & 4.2 \\
\hline
\end{tabular}

* Leachate collected from the mature anaerobic bioreactors.

\section{Solid Waste Characterization}

FTIR spectral data for solid waste removed from the anaerobic bioreactors and from each deconstructed FB are presented in Figure C-2 for FBs 1-3, respectively. A summary of the peaks identified in these leachate samples is provided in Table 4-8. Figure 4-7 shows the scores plot (PC 1 vs. PC 2) for these samples. Loading plots for PCs 1 and 2 are provided in Appendix C (Figure 4-7). 
Table 4-8. Summary of FTIR Observations for Solid Waste Samples

\begin{tabular}{|c|c|c|}
\hline Parameter & Wavenumber & Functional Groups \\
\hline \multirow{5}{*}{ Initial Waste $^{a}$} & $2920 \mathrm{~cm}^{-1}$ and $2850 \mathrm{~cm}^{-1}$ & Aliphatic Methylene \\
\hline & $1420 \mathrm{~cm}^{-1}$ & $\begin{array}{c}\text { Carboxylic Acid, Carbonate } \\
\text { (COO-Stretch) }\end{array}$ \\
\hline & $1227 \mathrm{~cm}^{-1}$ & Polysaccharides \\
\hline & $1030 \mathrm{~cm}^{-1}$ & Inorganics \\
\hline & $875 \mathrm{~cm}^{-1}$ & Carbonate \\
\hline \multirow{3}{*}{ Mature Waste $^{\mathrm{b}}$} & $2920 \mathrm{~cm}^{-1}$ and $2850 \mathrm{~cm}^{-1}$ & Aliphatic Methylene \\
\hline & $1420 \mathrm{~cm}^{-1}$ & Carboxylic; Carbonate (COO-) \\
\hline & $875 \mathrm{~cm}^{-1}$ & Carbonate \\
\hline \multirow{3}{*}{ Flushing Bioreactor $1^{\mathrm{c}}$} & $1740 \mathrm{~cm}^{-1}$ & Carboxylic $(\mathrm{C}=\mathrm{O})$ \\
\hline & $1014 \mathrm{~cm}^{-1}, 1031 \mathrm{~cm}^{-1}$, and $1050 \mathrm{~cm}^{-1}$ & Inorganics \\
\hline & $875 \mathrm{~cm}^{-1}$ & Carbonate \\
\hline \multirow{4}{*}{ Flushing Bioreactor $2^{\mathrm{c}}$} & $1740 \mathrm{~cm}^{-1}$ & Carboxylic $(\mathrm{C}=\mathrm{O})$ \\
\hline & $1030 \mathrm{~cm}^{-1}$ & Inorganics \\
\hline & $1420 \mathrm{~cm}^{-1}$ & Carboxylic; Carbonate (COO-) \\
\hline & $875 \mathrm{~cm}^{-1}$ & Carbonate \\
\hline \multirow{4}{*}{ Flushing Bioreactor $3^{c}$} & $1740 \mathrm{~cm}^{-1}$ & Carboxylic $(\mathrm{C}=\mathrm{O})$ \\
\hline & $1030 \mathrm{~cm}^{-1}$ & Inorganics \\
\hline & $1420 \mathrm{~cm}-1$ & Carboxylic; Carbonate (COO-) \\
\hline & $875 \mathrm{~cm}-1$ & Carbonate \\
\hline
\end{tabular}
a. L/S of 0
b. $\mathrm{L} / \mathrm{S}$ of 5
c. $\mathrm{L} / \mathrm{S}$ of 15 


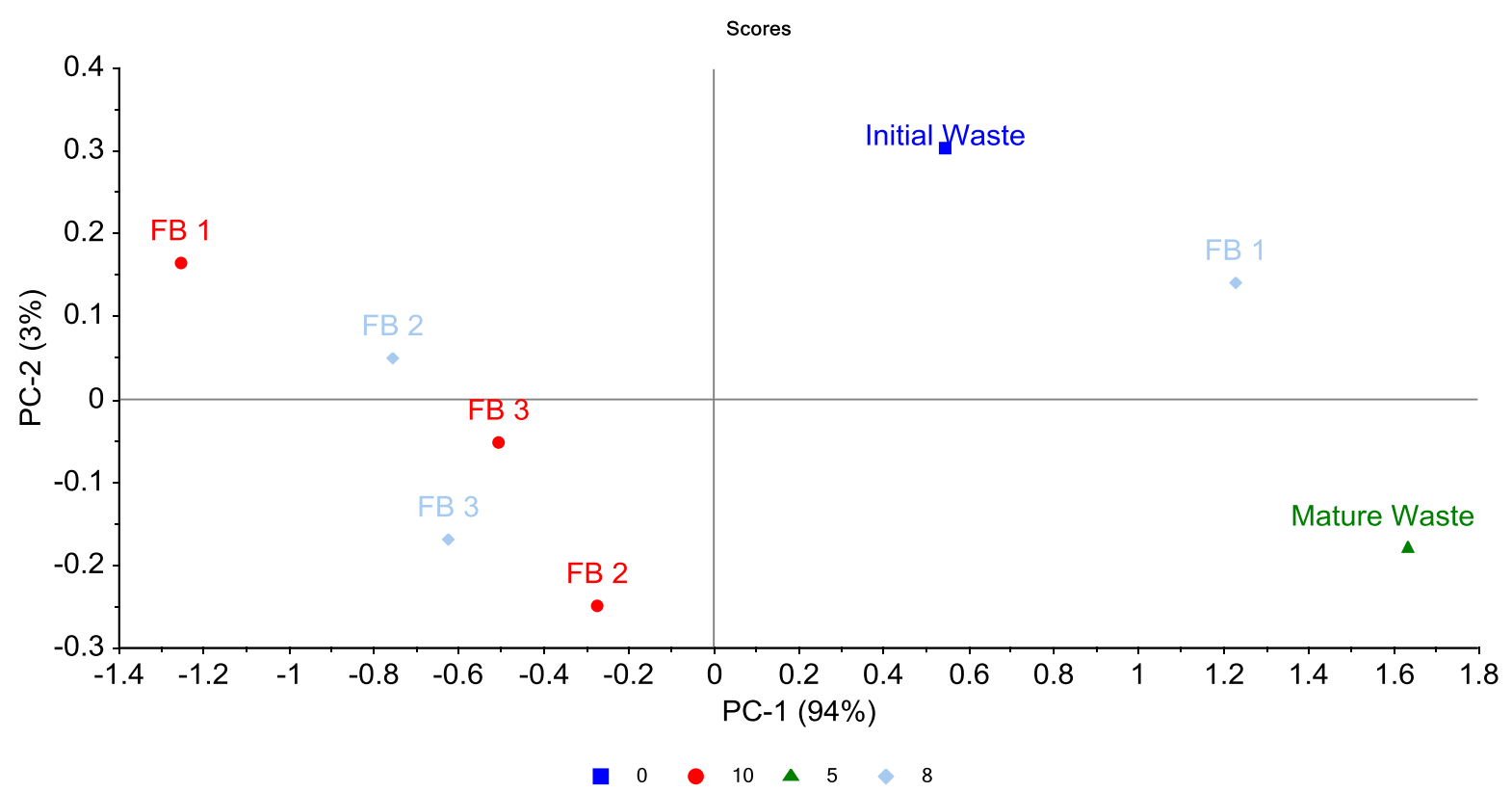

Figure 4-7. PCA Scores Plot of FTIR Spectrum of Initial, Mature, and FBs 1-3 (L/S of 8-10) Solid Waste

Table 4-9. Summary of PCs for Anaerobic and FB Waste Samples

\begin{tabular}{|c|c|c|c|c|c|c|c|}
\hline \multicolumn{2}{|c|}{ PC $1(+)$} & \multicolumn{2}{|c|}{ PC $1(-)$} & \multicolumn{2}{|c|}{ PC $2(+)$} & \multicolumn{2}{|c|}{ PC $2(-)$} \\
\hline Wavenumber & $\begin{array}{l}\text { Functional } \\
\text { Group }\end{array}$ & Wavenumber & Functional Group & Wavenumber & $\begin{array}{l}\text { Functional } \\
\text { Group }\end{array}$ & Wavenumber & $\begin{array}{l}\text { Functional } \\
\text { Group }\end{array}$ \\
\hline \multirow[t]{6}{*}{2981} & $\begin{array}{l}\text { Aromatic } \\
(C=C \\
\text { Stretching })\end{array}$ & 2920 & $\begin{array}{l}\text { Aliphatic Methylene } \\
\text { (C-H) }\end{array}$ & 1280 & $\begin{array}{l}\text { Carboxylic } \\
\text { Acid (C-O } \\
\text { Stretching) }\end{array}$ & 2981 & $\begin{array}{l}\text { Aromatic } \\
(\mathrm{C}=\mathrm{C} \\
\text { Stretching })\end{array}$ \\
\hline & & 2850 & $\begin{array}{l}\text { Aliphatic Methylene } \\
\text { (C-H) }\end{array}$ & 875 & $\begin{array}{l}\text { Carbonate } \\
\text { (C-O) }\end{array}$ & 1032 & $\begin{array}{c}\text { Inorganics } \\
\text { (Si-O } \\
\text { Stretch) }\end{array}$ \\
\hline & & 1505 & Lignin & & & & \\
\hline & & 1418 & $\begin{array}{c}\text { Carboxylic Acid, } \\
\text { Carbonate (COO- } \\
\text { Stretch) }\end{array}$ & & & & \\
\hline & & 1030 & $\begin{array}{l}\text { Inorganics (Si-O } \\
\text { Stretch) }\end{array}$ & & & & \\
\hline & & 875 & Carbonate $(\mathrm{C}-\mathrm{O})$ & & & & \\
\hline
\end{tabular}

Waste degradation in the anaerobic bioreactor and FBs 1-3 was captured by the changes in the PCs. These changes are reflected by the spatial shifts observed for each sample on the score plot. PCs 1 and 2 contributed $94 \%$ and 3\% of the overall variance, respectively, in the FTIR spectra among waste samples (Table 4-9). Looking at the changes in the spatial distribution of 
the initial waste relative the mature it was observed that there were no changes in positive PC 1 but there was a transition from positive PC 2 to negative PC 1 . Positive PC 1 was explained by aromaticity $\left(2981 \mathrm{~cm}^{-1} ; \mathrm{C}=\mathrm{C}\right)$. Changes in this functional group were not observed in the other reactors. As waste degraded anaerobically, peaks at $1104 \mathrm{~cm}^{-1}$ and $1054 \mathrm{~cm}^{-1}$ disappeared. These peaks are characteristic of carbohydrates (Sohoo et al., 2012), and this disappearance is presumably due to the conversion to simple sugars and then eventually to methane and carbon dioxide. A positive PC was related to aliphatic methylene, lignin, carboxylic acid/carbonate, and inorganic (Si-O stretch) groups. The appearance of small peaks in the mature waste (L/S of 5) at $2920 \mathrm{~cm}^{-1}$ and $2850 \mathrm{~cm}^{-1}$ is due to the presence of aliphatic methylene groups which have been correlated to reactivity of waste. Smidt and Schwanninger (2007) reported a decrease in the aliphatic methylene peaks for 15-year old waste characterized by FTIR. However, as shown in Appendix C (Figure C-5), the aliphatic methylene groups slightly increased in intensity in the mature waste relative to the initial waste, which was not expected and may be attributed to waste heterogeneity.

By a L/S of 10, FB 1 waste was described by a negative PC 1 and positive PC 2 which represent methylene aliphatic, lignin, carboxylic, and carbonate groups (Table 4-9). The negative PC 1 was related to FB 2 at $\mathrm{L} / \mathrm{S}$ of 8 and 10. Treatment over a $\mathrm{L} / \mathrm{S}$ of 8.0 to 10 , caused a shift in PC 2 from the decrease in carbonate $(875 \mathrm{~cm})$, aromatic $(\mathrm{C}=\mathrm{C}$ stretching), and inorganic $(\mathrm{Si}-\mathrm{O}$ stretch) groups relative to both the initial and mature waste samples. FB 3 did not have significant changes in the associated PCs (-PC 1 and -PC 2) as shown in Figure 4-7. The location of the FB 3 PCs corresponded to a decrease in aliphatic methylene, lignin, carboxylic, inorganics (Si-O), and carbonate (C-O) functional groups. 
Peaks at $2920 \mathrm{~cm}^{-1}$ and $2850 \mathrm{~cm}^{-1}$ (aliphatic methylene groups) were well defined at L/S of 8.0 but evolved into multiple peaks after further treatment in FB 1 (L/S of 15). There was a reduction in the intensity, then disappearance of these peaks with increasing L/S in FBs 2 and 3. An overall reduction or disappearance of the aliphatic methylene peaks supports the reduced reactivity of the waste, which suggests further stabilization relative to the mature waste (L/S of 5.0) was achieved.

All of the waste removed from the FBs, excluding FB 1 at L/S of 8.0, were associated with a negative PC 1 which represents carboxylic acid/carbonate, inorganics (Si-O Stretch), and carbonate peaks. The inorganic peak in FB 1 was initially present in the mature waste (L/S of 5) at $1029 \mathrm{~cm}^{-1}$ but evolved into three peaks at $1014 \mathrm{~cm}^{-1}, 1031 \mathrm{~cm}^{-1}$, and $1050 \mathrm{~cm}^{-1}$ during treatment. At L/S of 8, waste from FBs 2 and 3 exhibited the same inorganic peaks at $1014 \mathrm{~cm}^{-1}$, $1031 \mathrm{~cm}^{-1}$, and $1050 \mathrm{~cm}^{-1}$ which eventually devolved into a single peak at $1030 \mathrm{~cm}^{-1}$. These differences are most likely attributed to waste heterogeneity but do support the mineralization of organic matter during the stabilization process. Overall, as the waste stabilized there was a dominance of inorganic functional groups with respect to aliphatic methylene and aromatic carbon. A similar trend for old waste was observed by Smidt et al. (2011).

\section{Characterization of Humic Acid Extracted from Solid Waste}

HA was extracted from solid waste during anaerobic and FB treatment. These data were compared to solid waste and leachate characteristics. The overall goal of HA analysis was to identify the changes occurring during treatment. HA was not extracted from leachate since the available volume was insufficient to extract the HA mass needed for analysis. The HA concentration of mature waste was approximately $17 \mathrm{mg}$ of HA/kg of dry waste. The HA content 
increased in all FBs between L/S of 5.0 and 8.0 (Figure 4-8). FB 3 had the highest concentration of $\mathrm{HA}$ at $\mathrm{L} / \mathrm{S}$ of 15 , followed by FBs 2 and 1, respectively.

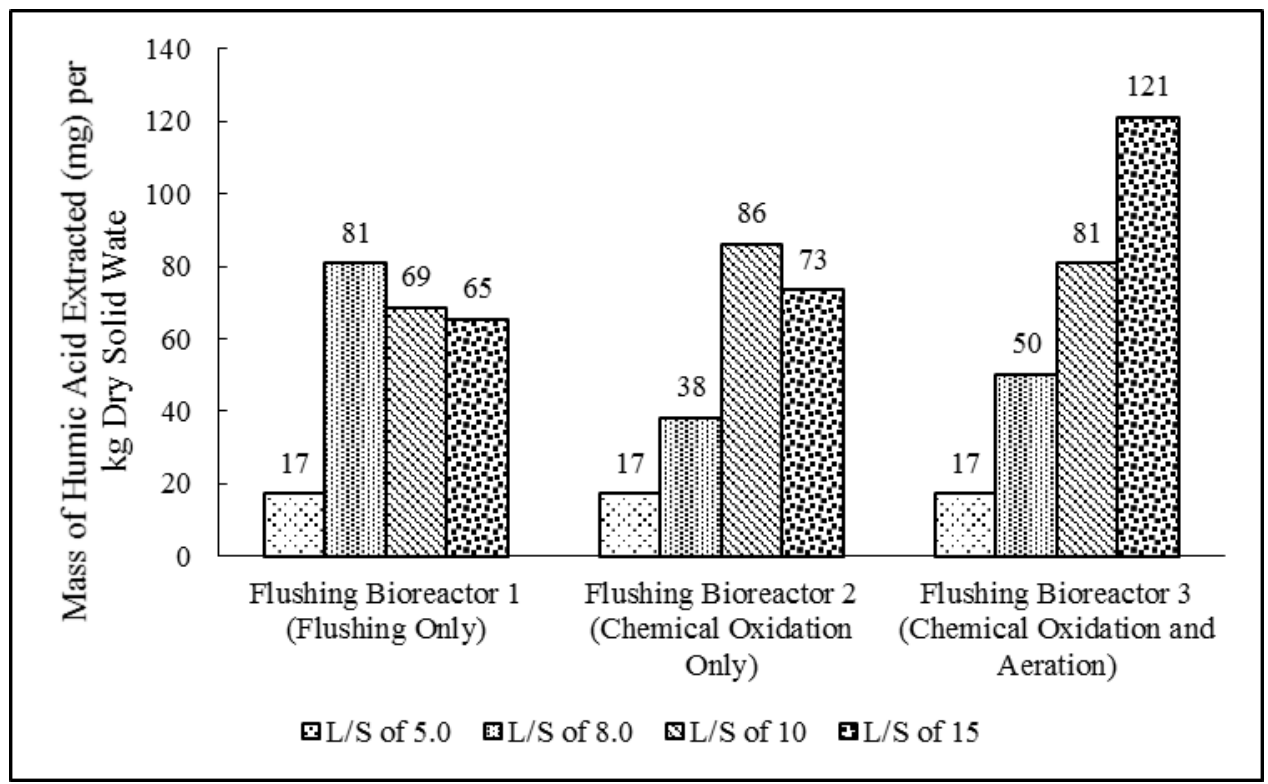

Figure 4-8. Mass of HA Extracted from Solid Waste

The ${ }^{13} \mathrm{C}$ NMR spectra of HA extracted from the waste removed from the laboratory-scale anaerobic bioreactor (L/S of 5.0) and FBs 1-3 at L/S of 15 are provided in Figure 4-9. Three groups of chemical shifts were integrated to observe the overall changes in the distribution of aliphatic (0-110 ppm), aromatic (110-165 ppm), and carboxylic (165-200 ppm) carbon. The overall area was used to determine the distribution of carbon for these three groups as summarized in Table 10. The HA extracted from the mature waste was dominated by aliphatic carbon with aromatic carbon less intense. As waste was further treated the HA structural characteristics underwent changes reflected by the aliphatic, aromatic, and carboxylic carbon behavior in NMR spectra. Aliphatic carbon content decreased in FB 1 while there was an increase in the aromatic carbon. There was a significant decrease in the carboxylic carbon content during flushing which is expected as the spectral characteristics of the HA exhibited a lower carboxylic acid content relative to FA (Citation). This observation was confirmed by FTIR 
data. HA extraction from FBs 2 and 3 wastes had similar characteristics despite the different treatments. There was a decrease in the aliphatic carbon for both FBs while there was minimal change in aromatic carbon. The carboxylic acid content increased relative to the mature waste, which agrees with the leachate spectral characteristics $\left(\mathrm{E}_{4} / \mathrm{E}_{6}\right.$; Table 4-5).

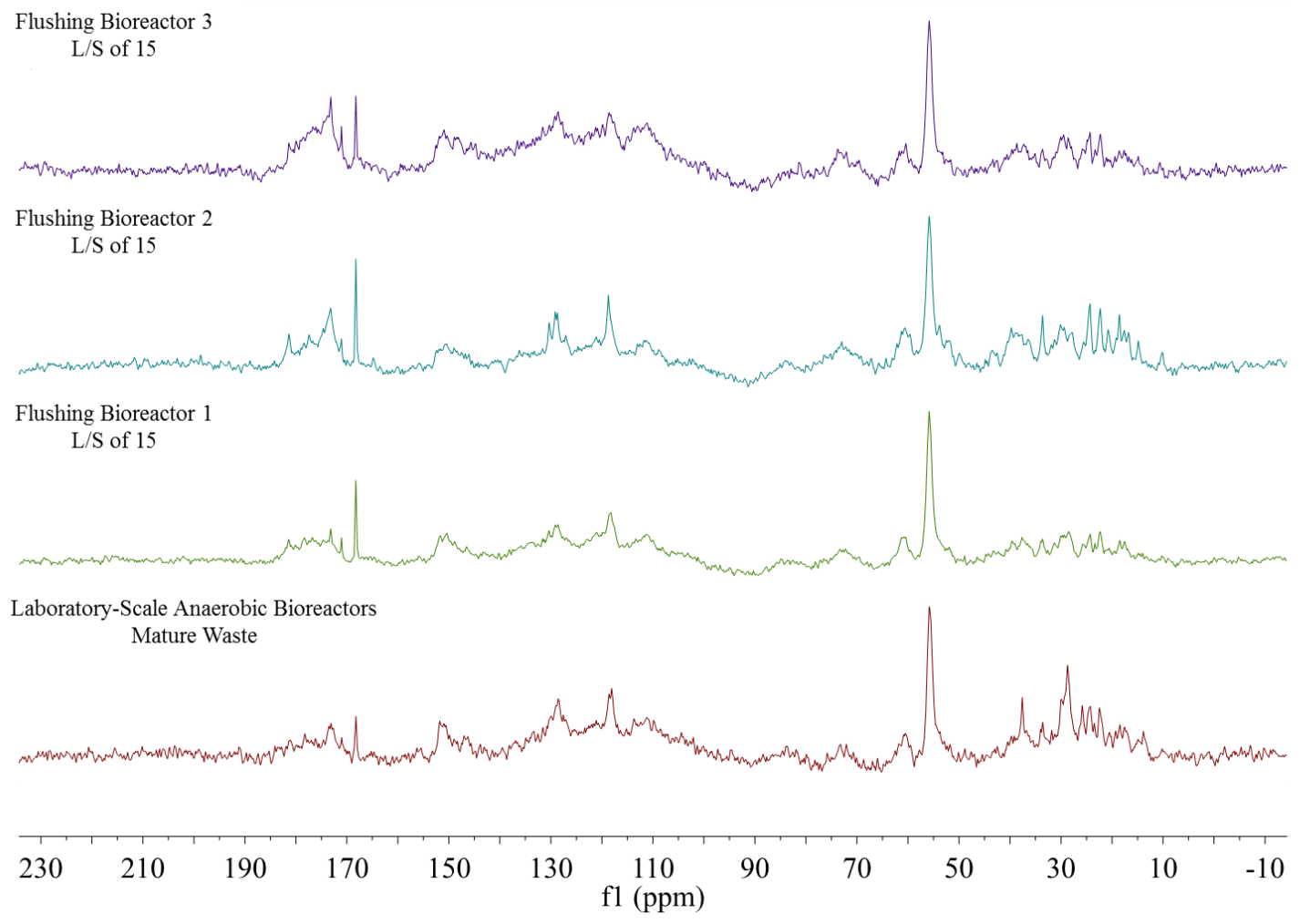

Figure 4-9. NMR Spectra of HA Extracted from Mature and FB Waste 
Table 4-10. Distribution of Carbon of Chemical Shifts of HA Extracted from Waste Removed from Laboratory-Scale Anaerobic Bioreactors and Flushing Bioreactors

\begin{tabular}{|c|c|c|c|}
\hline Extracted Humic Acid & $\begin{array}{c}\text { Aliphatic } \\
\text { Carbon } \\
(0-110 \\
\mathrm{ppm})\end{array}$ & $\begin{array}{c}\text { Aromatic } \\
\text { Carbon } \\
(110-165 \\
\mathrm{ppm})\end{array}$ & $\begin{array}{c}\text { Carboxylic } \\
\text { Carbon } \\
(165-200 \\
\mathrm{ppm})\end{array}$ \\
\hline Laboratory-Scale Anaerobic Bioreactors & $52 \%$ & $32 \%$ & $16 \%$ \\
\hline Flushing Bioreactor 1 (L/S of 10) & $45 \%$ & $48 \%$ & $6 \%$ \\
\hline Flushing Bioreactor 2 (L/S of 10) & $48 \%$ & $29 \%$ & $23 \%$ \\
\hline Flushing Bioreactor 3 (L/S of 10) & $44 \%$ & $31 \%$ & $25 \%$ \\
\hline
\end{tabular}

\section{$\underline{\text { Discussion }}$}

FTIR spectra of FB waste and leachate supported stabilization of waste during the additional treatment. Organic functional groups associated with aliphatic methylenes $\left(2920 \mathrm{~cm}^{-1}\right.$ and 2850 $\mathrm{cm}^{-1}$ ) were present in both leachate and solid waste samples during the early stages of anaerobic degradation and disappeared once these samples underwent treatment and were further stabilized. Between a L/S of 2.6-3.5 (Table 4-3) in the laboratory-scale anaerobic reactors aliphatic methytlene functional groups were no longer present concomitantly correlates with a decrease COD of 10,000 to $6,500 \mathrm{mg} / \mathrm{L}$ and a BOD of less than 1,500 (BOD/COD of $\sim 0.15$ ). A more exact relationship suggests a statistical analysis between these functional groups and COD was not possible because leachate was not collected between a L/S of 2.6 and 3.5. The mature waste spectrum was dominated by inorganic functional groups when the BOD/COD was less than 0.1 and the COD was less than 6,500 $\mathrm{mg} / \mathrm{L}$.

Stability indicators have been developed as a means of assessing the performance of a landfill relative to achieving complete stabilization (Knox et al., 2005; Barlaz, 2006; Cossu et al., 2007; Knox et al., 2005; Prantl et al., 2006; Ritzkowski and Stegmann, 2013). Results from Bolyard and Reinhart (2016) for conventional parameters for FBs 1-3 are presented in Tables 411 and 4-12 along with the associated chemical functional groups (i.e., FTIR peaks) from this 
study. FTIR peaks assignments for stabilized waste and the associated leachate have not been published previously. From our study, it appears that these data (Tables 11 and 12) could be used to assess the stability of waste samples as opposed to more time consuming analyses (e.g., BMP, VS, cellulose, hemicellulose, and lignin). 
Table 4-11. Comparison of Conventional and FTIR Solid Waste Stability Indicators

\begin{tabular}{|c|c|c|c|c|c|}
\hline Parameter & $\begin{array}{c}\text { Biodegradable } \\
\text { Volatile Solids } \\
\text { (\% of dry } \\
\text { weight) }\end{array}$ & $\mathrm{C} / \mathrm{L}$ & $\begin{array}{c}\text { Biochemical } \\
\text { Methane Potential } \\
\text { (21 days) } \mathrm{m}^{3} \\
\mathrm{CH}_{4} / \mathrm{Mg} \text { total dry } \\
\text { waste }\end{array}$ & $\begin{array}{l}\text { FTIR Dominant } \\
\text { Group } \\
\text { (wavenumber) }\end{array}$ & $\begin{array}{l}\text { Chemical } \\
\text { Functional } \\
\text { Groups } \\
\text { Associated with } \\
\text { FTIR } \\
\text { Wavenumbers }\end{array}$ \\
\hline $\begin{array}{c}\text { Stabilized } \\
\text { Waste } \\
\text { Characteristics } \\
\text { Literature } \\
\text { Values }\end{array}$ & $<25 \%{ }^{c}$ & $\begin{array}{l}0.16- \\
0.6^{\mathrm{d}}\end{array}$ & $10-15^{\mathrm{e}}$ & $-{ }^{f}$ & $-{ }^{f}$ \\
\hline \multirow{3}{*}{ Mature Waste $^{\mathrm{a}}$} & \multirow{3}{*}{31} & \multirow{3}{*}{1.2} & \multirow{3}{*}{29} & $\begin{array}{c}2920 \mathrm{~cm}^{-1} \text { and } \\
2850 \mathrm{~cm}^{-1}\end{array}$ & $\begin{array}{l}\text { Aliphatic } \\
\text { Methylene }\end{array}$ \\
\hline & & & & $1420 \mathrm{~cm}^{-1}$ & $\begin{array}{l}\text { Carboxylic; } \\
\text { Carbonate } \\
\text { (COO-) }\end{array}$ \\
\hline & & & & $875 \mathrm{~cm}^{-1}$ & Carbonate \\
\hline \multirow{4}{*}{$\begin{array}{c}\text { Flushing } \\
\text { Bioreactor } 1^{\mathrm{a}, \mathrm{b}}\end{array}$} & \multirow{4}{*}{24} & \multirow{4}{*}{0.33} & \multirow{4}{*}{3.6} & $2920 \mathrm{~cm}^{-1}$ & $\begin{array}{c}\text { Aliphatic } \\
\text { Methylene }\end{array}$ \\
\hline & & & & $1740 \mathrm{~cm}^{-1}$ & $\begin{array}{c}\text { Carboxylic } \\
(\mathrm{C}=\mathrm{O})\end{array}$ \\
\hline & & & & $\begin{array}{c}1014 \mathrm{~cm}^{-1}, 1031 \\
\mathrm{~cm}^{-1} \text {, and } 1050 \mathrm{~cm}^{-}\end{array}$ & Inorganics \\
\hline & & & & $875 \mathrm{~cm}^{-1}$ & Carbonate \\
\hline \multirow{5}{*}{$\begin{array}{c}\text { Flushing } \\
\text { Bioreactor } 2^{\mathrm{a}, \mathrm{b}}\end{array}$} & \multirow{5}{*}{25} & \multirow{5}{*}{0.47} & \multirow{5}{*}{9} & $2920 \mathrm{~cm}^{-1}$ & $\begin{array}{l}\text { Aliphatic } \\
\text { Methylene }\end{array}$ \\
\hline & & & & $1740 \mathrm{~cm}^{-1}$ & $\begin{array}{c}\text { Carboxylic } \\
(\mathrm{C}=\mathrm{O})\end{array}$ \\
\hline & & & & $1030 \mathrm{~cm}^{-1}$ & Inorganics \\
\hline & & & & $1420 \mathrm{~cm}^{-1}$ & $\begin{array}{l}\text { Carboxylic; } \\
\text { Carbonate } \\
\text { (COO-) }\end{array}$ \\
\hline & & & & $875 \mathrm{~cm}^{-1}$ & Carbonate \\
\hline \multirow{4}{*}{$\begin{array}{l}\text { Flushing } \\
\text { Bioreactor } 3^{\mathrm{a}, \mathrm{b}}\end{array}$} & \multirow{4}{*}{27} & \multirow{4}{*}{0.62} & \multirow{4}{*}{15} & $1740 \mathrm{~cm}^{-1}$ & $\begin{array}{c}\text { Carboxylic } \\
(\mathrm{C}=\mathrm{O})\end{array}$ \\
\hline & & & & $1030 \mathrm{~cm}^{-1}$ & Inorganics \\
\hline & & & & $1420 \mathrm{~cm}-1$ & $\begin{array}{c}\text { Carboxylic; } \\
\text { Carbonate } \\
\text { (COO-) }\end{array}$ \\
\hline & & & & $875 \mathrm{~cm}-1$ & Carbonate \\
\hline
\end{tabular}
a. Bolyard and Reinhart, 2016
b. L/S of 15
c. Knox et al., 2005
d. Barlaz, 2006
e. Cossu et al., 2007; Knox et al., 2005; Prantl et al., 2006; Ritzkowski and Stegmann, 2013
f. Data unavailable on the spectroscopic characteristics of stabilized waste 
Table 4-12. Comparison of Conventional and FTIR Leachate Indicators

\begin{tabular}{|c|c|c|c|c|c|c|}
\hline $\begin{array}{c}\text { Leachate } \\
\text { Stability } \\
\text { Indicators }\end{array}$ & $\begin{array}{l}\text { BOD/COD } \\
\text { (unitless) }\end{array}$ & $\begin{array}{l}\text { BOD } \\
(\mathrm{mg} / \mathrm{L})\end{array}$ & $\begin{array}{l}\text { COD } \\
(\mathrm{mg} / \mathrm{L})\end{array}$ & $\begin{array}{l}\text { Ammonia- } \\
\mathrm{N}(\mathrm{mg} / \mathrm{L})\end{array}$ & Wavenumber & $\begin{array}{l}\text { Chemical } \\
\text { Functional } \\
\text { Group }\end{array}$ \\
\hline $\begin{array}{l}\text { Stabilized Waste } \\
\text { Characteristics } \\
\text { Literature Values }\end{array}$ & $<0.1^{\mathrm{c}}$ & $<100^{\mathrm{d}}$ & $<200^{\mathrm{e}}$ & $<10^{\mathrm{f}}$ & $-g$ & $-g$ \\
\hline \multirow{3}{*}{ Mature Waste $^{\mathrm{a}}$} & \multirow{3}{*}{0.03} & \multirow{3}{*}{161} & \multirow{3}{*}{5,350} & \multirow{3}{*}{472} & $1420 \mathrm{~cm}^{-1}$ & $\begin{array}{c}\text { Carboxylic } \\
\text { Acids, Carbonate } \\
\text { (COO-Stretch) }\end{array}$ \\
\hline & & & & & $\begin{array}{c}1447 \mathrm{~cm}^{-1} \text { and } 875 \\
\mathrm{~cm}^{-1}\end{array}$ & $\begin{array}{c}\text { Inorganic } \\
\text { Compounds } \\
\end{array}$ \\
\hline & & & & & $875 \mathrm{~cm}^{-1}$ & Carbonate \\
\hline \multirow{3}{*}{$\begin{array}{c}\text { Flushing } \\
\text { Bioreactor } 1^{\mathrm{a}, \mathrm{b}}\end{array}$} & \multirow{3}{*}{0.06} & \multirow{3}{*}{9} & \multirow{3}{*}{150} & \multirow{3}{*}{6.6} & $1420 \mathrm{~cm}^{-1}$ & $\begin{array}{c}\text { Carboxylic } \\
\text { Acids, Carbonate } \\
\text { (COO-Stretch) }\end{array}$ \\
\hline & & & & & $1030 \mathrm{~cm}^{-1}$ & Inorganics \\
\hline & & & & & $875 \mathrm{~cm}^{-1}$ & Carbonate $^{11,15}$ \\
\hline \multirow{3}{*}{$\begin{array}{c}\text { Flushing } \\
\text { Bioreactor } 2^{\mathrm{a}, \mathrm{b}}\end{array}$} & \multirow{3}{*}{0.068} & \multirow{3}{*}{23.5} & \multirow{3}{*}{347} & \multirow{3}{*}{129} & $\begin{array}{c}2920 \mathrm{~cm}^{-1} \text { and } 2850 \\
\mathrm{~cm}^{-1}\end{array}$ & $\begin{array}{c}\text { Aliphatic } \\
\text { methylene }\end{array}$ \\
\hline & & & & & $2981 \mathrm{~cm}^{-1}$ & $\begin{array}{c}\text { Aromatic carbon } \\
(\mathrm{C}=\mathrm{C})\end{array}$ \\
\hline & & & & & $1420 \mathrm{~cm}^{-1}$ & $\begin{array}{c}\text { Carboxylic } \\
\text { Acids, Carbonate } \\
\text { (COO-Stretch) }\end{array}$ \\
\hline \multirow{3}{*}{$\begin{array}{c}\text { Flushing } \\
\text { Bioreactor } 3^{\mathrm{a}, \mathrm{b}}\end{array}$} & \multirow{3}{*}{0.0024} & \multirow{3}{*}{3} & \multirow{3}{*}{1250} & \multirow{3}{*}{0.45} & $2981 \mathrm{~cm}^{-1}$ & $\begin{array}{c}\text { Aromatic carbon } \\
(\mathrm{C}=\mathrm{C})\end{array}$ \\
\hline & & & & & $\begin{array}{c}2920 \mathrm{~cm}^{-1} \text { and } 2850 \\
\mathrm{~cm}^{-1}\end{array}$ & $\begin{array}{l}\text { Aliphatic } \\
\text { methylene }\end{array}$ \\
\hline & & & & & $1420 \mathrm{~cm}^{-1}$ & $\begin{array}{c}\text { Carboxylic } \\
\text { Acids, Carbonate } \\
\text { (COO-Stretch) }\end{array}$ \\
\hline
\end{tabular}

a. Bolyard and Reinhart, 2016

b. $\mathrm{L} / \mathrm{S}$ of 15

c. Booker and Ham, 1982; Cossu et al., 2007; Kjeldsen et al., 2002

d. Kjeldsen et al., 2002

e. Cossu et al., 2007

f. Knox et al., 2005

g. Data unavailable on the spectroscopic characteristics of leachate 


\section{Conclusions}

This research provided a better understanding of changes in waste characteristics when waste transitions from mature then to stable under extensive treatment. The stability of waste was not indicated by leachate quality alone. Changes in the solid waste occurred while $\mathrm{BOD}_{5} / \mathrm{COD}$ in FBs 1 and 2 did not change significantly. The $\mathrm{BOD}_{5} / \mathrm{COD}$ in FB 3 decreased by an order of magnitude due to aeration but changes in the waste, relative to FBs 1 and 2, were not observed. FTIR is a simple tool that revealed changes in waste stability (i.e., shift from dominance of organic to inorganic functional groups) when compared to changes in conventional parameters occurred (e.g., $\left.\mathrm{BOD}_{5} / \mathrm{COD}\right)$. Conventional parameters still need to be quantified in order to correlate the changes in the FTIR spectra to waste stability. The PCA tool discussed in this study could be used to better understand waste stability. This tool could be implemented in the field to characterize waste extracted from drilling. Future applications of FTIR includes developing a model, using PCA, to predict the stability of extracted waste samples. A library of FTIR spectra of fresh waste would need to be created. 


\section{$\underline{\text { References }}$}

Amir, S., Hafidi, M., Bailly, J.-R., \& Revel, J.-C. (2003). Characterization of humic acids extracted from sewage sludge during composting and of their Sephadex ${ }^{\circledR}$ gel fractions. Agronomie, 23(3), 269-275.

APHA. (2005). Standard Methods for the Examination of Water and Wastewater.

Bolyard, S. C., \& Reinhart, D. R. (2016). Application of landfill treatment approaches for stabilization of municipal solid waste. Waste Management. doi: http://dx.doi.org/10.1016/j.wasman.2016.01.024

Bolyard, S. C., Reinhart, D. R., \& Santra, S. (2013). Behavior of Engineered Nanoparticles in Landfill Leachate. Environmental Science \& Technology, 47(15), 8114-8122. doi: $10.1021 / \mathrm{es} 305175 \mathrm{e}$

Castaldi, P., Alberti, G., Merella, R., \& Melis, P. (2005). Study of the organic matter evolution during municipal solid waste composting aimed at identifying suitable parameters for the evaluation of compost maturity. Waste Management, 25(2), 209-213. doi: http://dx.doi.org/10.1016/j.wasman.2004.12.011

Chefetz, B., Hader, Y., \& Chen, Y. (1998). Dissolved Organic Carbon Fractions Formed during Composting of Municipal Solid Waste: Properties and Significance. Acta hydrochimica et hydrobiologica, 26(3), 172-179. doi: 10.1002/(SICI)1521401X(199805)26:3<172::AID-AHEH172>3.0.CO;2-5

Domeizel, M., Khalil, A., \& Prudent, P. (2004). UV spectroscopy: a tool for monitoring humification and for proposing an index of the maturity of compost. Bioresource Technology, 94(2), 177-184. doi: http://dx.doi.org/10.1016/j.biortech.2003.11.026

Fukushima, A., Kusano, M., Redestig, H., Arita, M., \& Saito, K. (2009). Integrated omics approaches in plant systems biology. Current Opinion in Chemical Biology, 13(5-6), 532-538. doi: http://dx.doi.org/10.1016/j.cbpa.2009.09.022

González-Vila, F. J., Almendros, G., \& Madrid, F. (1999). Molecular alterations of organic fractions from urban waste in the course of composting and their further transformation in amended soil. Science of The Total Environment, 236(1-3), 215-229. doi: http://dx.doi.org/10.1016/S0048-9697(99)00284-3

Hanson, J. (2001). Functional Group Chemistry: Royal Society of Chemistry.

IHSS. (2007). What are Humic Substances? , from http://www.humicsubstances.org/whatarehs.html

Lguirati, A., Ait Baddi, G., El Mousadik, A., Gilard, V., Revel, J. C., \& Hafidi, M. (2005). Analysis of humic acids from aerated and non-aerated urban landfill composts. International Biodeterioration \& Biodegradation, 56(1), 8-16. doi: http://dx.doi.org/10.1016/j.ibiod.2005.03.004

Morris, J. W. F., \& Barlaz, M. A. (2011). A performance-based system for the long-term management of municipal waste landfills. Waste Management, 31(4), 649-662. doi: http://dx.doi.org/10.1016/j.wasman.2010.11.018

Nanny, M. A., \& Ratasuk, N. (2002). Characterization and comparison of hydrophobic neutral and hydrophobic acid dissolved organic carbon isolated from three municipal landfill leachates. Water Research, 36(6), 1572-1584. doi: http://dx.doi.org/10.1016/S0043$\underline{1354(01) 00359-1}$ 
Owen, W. F., Stuckey, D. C., Healy Jr, J. B., Young, L. Y., \& McCarty, P. L. (1979). Bioassay for monitoring biochemical methane potential and anaerobic toxicity. Water Research, 13(6), 485-492. doi: http://dx.doi.org/10.1016/0043-1354(79)90043-5

Owens, J. M., \& Chynoweth, D. P. (1992). Biochemical Methane Potential of MSW Components Paper presented at the International Symposium on Anaerobic digestion of Solid Waste.

Reinhart, D. R., \& Townsend, T. G. (1998). Landfill bioreactor design and operation: Boca Raton, Fla : Lewis Publishers, c1998.

Rivero, C., Chirenje, T., Ma, L. Q., \& Martinez, G. (2004). Influence of compost on soil organic matter quality under tropical conditions. Geoderma, 123(3-4), 355-361. doi: http://dx.doi.org/10.1016/j.geoderma.2004.03.002

Smidt, E., Bohm, K., \& Schwanniner, M. (2011). The Application of FT-IR Spectroscopy in Waste Management. In G. Nikolic (Ed.), New Analytical Approaches and FTIR Strategies.

Smidt, E., Eckhardt, K.-u., Lechner, P., Schulten, H.-r., \& Leinweber, P. (2005). Characterization of different decomposition stages of biowaste using FT-IR spectroscopy and pyrolysis-field ionization mass spectrometry. Biodegradation, 16(1), 67-79. doi: 10.1007/s10531-004-0430-8

Smidt, E., Lechner, P., Schwanninger, M., Haberhauer, G., \& Gerzabek, M. H. (2002). Characterization of Waste Organic Matter by FT-IR Spectroscopy: Application in Waste Science. Applied Spectroscopy, 56(9), 1170-1175.

Wang, X., Padgett, J. M., Powell, J. S., \& Barlaz, M. A. (2013). Decomposition of forest products buried in landfills. Waste Management, 33(11), 2267-2276. doi: http://dx.doi.org/10.1016/j.wasman.2013.07.009

Wu, Y., Zhou, S., Qin, F., Ye, X., \& Zheng, K. (2010). Modeling physical and oxidative removal properties of Fenton process for treatment of landfill leachate using response surface methodology (RSM). Journal of Hazardous Materials, 180(1-3), 456-465. doi: http://dx.doi.org/10.1016/j.jhazmat.2010.04.052 


\section{CHAPTER 5}

\section{EVALUATION OF LEACHATE DISSOLVED ORGANIC NITROGEN DISCHARGE EFFECT ON WASTEWATER EFFLUENT QUALITY}

\section{$\underline{\text { Abstract }}$}

Leachate is frequently discharged to local municipal wastewater treatment plants (WWTPs) because of the cost and complexity of onsite treatment. The organic constituents in leachate can be problematic for WWTPs as their recalcitrance causes them to pass through conventional treatment processes and have the potential to negatively affect effluent quality (Zhao et al., 2013). Nitrogen is now limited more and more frequently in WWTP effluents with the concern of causing eutrophication in discharge waters. Twelve leachates from eight landfills in Florida and California where characterized for total nitrogen (TN) and dissolved organic nitrogen (DON). The average concentration of TN and DON in leachate was approximately $1,160 \mathrm{mg} / \mathrm{L}$ and $40.7 \mathrm{mg} / \mathrm{L}$, respectively. Solid-phase extraction was used to fractionate the DON based on hydrophobic and hydrophilic chemical properties. The bioavailability of DON had been shown to the related to hydrophilicity (Liu et al., 2011); the hydrophobic DON is considered to be recalcitrant. The average leachate concentrations of bioavailable DON (bDON) and recalcitrant (rDON) was $16.5 \mathrm{mg} / \mathrm{L}$ and $18.4 \mathrm{mg} / \mathrm{L}$, respectively. Bulk leachate characteristics were compared to rDON and bDON to determine which parameters were positively correlated to each fraction. However bDON and bulk leachate characteristics were not strongly correlated. rDON was positively correlated (95\% confidence interval) with color, total nitrogen, humic acid, and UV absorbance at $254 \mathrm{~nm}$. rDON and bDON fractions were characterized for color, chemical oxygen demand (COD), and UV absorbance at $254 \mathrm{~nm}, 465 \mathrm{~nm}$, and $665 \mathrm{~nm}$. 
Significant differences were observed between the two fractions. The hydrophilic fraction of DON (rDON) was highly colored. This fraction was also associated with over $60 \%$ of the total COD. The higher $\mathrm{UV}_{254 \mathrm{~nm}}$ absorbance, relative to $\mathrm{bDON}$, correlated well with $\mathrm{rDON}$ being associated with dissolved organic matter. Multiple leachate and wastewater co-treatment simulations were carried out to assess the effects of leachate on wastewater effluent quality at four different WWTPs. This approach brought to light that effluent quality exceeded $3 \mathrm{mg} / \mathrm{L}$ and $10 \mathrm{mg} / \mathrm{L}$ at leachate contributions of $10 \%$ and the two bDON removal scenarios (i.e., no removal and complete removal). The calculated pass-through of $\mathrm{rDON}$ and total DON at $10 \%$ and $1 \%$ volumetric contributions for the tested leachates assuming no removal ranged from 0.00435 $0.477 \mathrm{mg} / \mathrm{L}$ and $0.0266-9.71 \mathrm{mg} / \mathrm{L}$, respectively. The calculated pass-through of rDON and DON suggests that these nitrogen species could contribute to nutrient impairment of waterbodies. Photochemical modifications can promote the formation of more labile nitrogen species such as dissolved primary amines, ammonia-N, and other compounds yet to be identified (BushawNewton and Moran, 1999). Further studies are needed to quantify the production of labile nitrogen from the discharge of rDON and bDON to aquatic systems. 


\section{$\underline{\text { Introduction }}$}

Management of leachate generated by municipal solid waste (MSW) landfills poses significant challenges to landfill operators. Leachate characteristics vary dramatically over time because of changing conditions within the landfill. Leachate generated from recently placed waste has high organic compound concentrations; treating this leachate requires a combination of biological and physical-chemical processes. As the waste in the landfill ages, leachate volume declines, however, remaining constituents tend to be recalcitrant and treatment requirements increasingly complex (Batarseh et al., 2007a; Batarseh et al., 2007b; Cortez et al., 2011; Morris et al., 2003). In particular, organic constituents transition from aliphatic, small molecular weight compounds to highly aromatic humic substances (HS) (with high molecular weights) which originate from the condensation and polymerization of microbial degradation byproducts. These older leachates are also characterized by relatively large concentrations of nitrogen-containing compounds. The persistence of these compounds requires management of leachate for many decades, extending the costly post-closure care period. Leachate dissolved organic nitrogen (DON) is not typically included in MSW leachate analysis plans, therefore concentrations are not well documented. The nature of these compounds is also not well understood; fewer than $15 \%$ of the compounds contributing to DON have been identified (Dotson et al., 2009).

Leachate is frequently discharged to local municipal wastewater treatment plants (WWTPs) because of the cost and complexity of on-site treatment. Biological treatment processes utilized at WWTPs are designed to remove carbonaceous BOD and ammonia-N and leachate recalcitrant organic matter passes through. Therefore the organic constituents in leachate have the potential to negatively affect effluent quality (Zhao et al., 2013). Chlorination of these organic compounds can generate toxic disinfection byproducts (e.g., N-Nitrosodimethylamine (Mitch et al., 2003)) 
An additional concern is that aromatic compounds tend to absorb ultraviolet (UV) light, which has been shown to be high enough in leachate to interfere with the alternative method of disinfection of wastewater using UV at volumetric contributions as low as $0.01 \%$ of the WWTP influent (Reinhart and Bolyard, 2015).

Permit limits for WWTP effluent total nitrogen (TN) are typically between 3.0 and $10 \mathrm{mg} / \mathrm{L}$, depending on the discharge location (Rohrbacher et al., 2011). DON concentrations in domestic wastewater effluents, in the absence of other industrial sources, can range from $0.5-2.5 \mathrm{mg} / \mathrm{L}$ (Matthews et al., 2011). WWTP effluent nutrients can facilitate eutrophication and, depending on the severity of the algal blooms, dead zones can occur due to a decrease in dissolved oxygen. In 2003, a dead zone in the Chesapeake Bay spanned 150 miles from Baltimore to the York River (Chesapeake Bay Foundation, 2003). WWTPs were the second largest source of nitrogen pollution in the Chesapeake Bay. In order to combat these water quality issues, the U.S. Environmental Protection Agency developed Numeric Nutrient Criteria (NNC) for WWTPs aimed at lowering the TN and total phosphorus limits (EPA, 2015). These regulations will affect the effluent limits for WWTPs if there is reasonable potential for these sites to discharge nitrogen and phosphorus at concentrations that can cause or contribute to nutrient impairment of receiving waters.

Liu et al. (2011) estimated that approximately $80 \%$ of wastewater DON was bioavailable based on the fact that it stimulated algal growth under laboratory conditions. The bioavailability of DON in the Liu et al., (2011) study was correlated with the hydrophilic nature of the organic matter and referred to as bDON. DON that was characterized as hydrophobic was considered to be recalcitrant (rDON). The co-treatment of leachate with wastewater could negatively affect the quality and limit the use of receiving waters, which is of increasing concern to WWTP operators. 
Leachate DON is often comprised of low molecular weight material that will not be removed in conventional activated sludge processes (Chen et al., 2010). There is also concern that the rDON passing through WWTPs could become bioavailable after entering aquatic systems.

Photochemical reactions in aquatic systems can convert DON to more labile compounds (Bushaw-Newton and Moran, 1999) such as primary amines or ammonia-N (Bushaw et al., 1996; Vähätalo and Zepp, 2005). To date, there is no literature pertaining to the nature of leachate DON, its bioavailability, or the potential pass-through of this organic matter when cotreated with domestic wastewater.

This study focused on (1) quantifying TN and DON in leachate, (2) determining the bioavailability of these nitrogen species based on hydrophobic (rDON) and hydrophilic (bDON) fractions, and (3) simulating multiple leachate and wastewater co-treatment scenarios to assess the potential impact of leachate on WWTP effluent quality. Bulk leachate properties were compared to rDON and bDON concentrations to examine possible trends based on landfill age. rDON and bDON fractions were also characterized for color, COD concentrations, and ultraviolet (UV) absorbance at $254 \mathrm{~nm}, 465 \mathrm{~nm}$, and $665 \mathrm{~nm}$.

Using TN, DON, and rDON concentrations for the studied leachate samples, it was possible to simulate multiple scenarios of leachate and wastewater co-treatment. The contribution of leachate to $\mathrm{TN}$ effluent quality was estimated by using published $\mathrm{TN}$ removal efficiencies for four operating U.S. WWTPs described using summary statistics for three years of WWTP plant data (Bott and Parker, 2011). The advantage of this approach is bracket the expected DON concentrations in typical. These results could be used to develop a targeted field sampling plan based on leachate characteristics and volumetric contributions, and TN WWTP effluent limits to evaluate the effect of leachate co-treatment on effluent quality. 


\section{$\underline{\text { Materials and Methods }}$}

\section{Leachate Collection and Characterization}

A summary of eight Florida and California municipal solid waste landfills sampled is provided in Table 5-1. These sites represented multiple types of landfills (e.g., conventional, slurry wall) and different ages of waste. Samples were analyzed for DON, COD, dissolved organic carbon (DOC), $\mathrm{pH}$, ammonia-N, nitrate-N, nitrite-N, total Kjeldahl nitrogen (TKN), and UV absorbance, according to Standard Methods (APHA, 2005). Leachate was passed through a $0.45-\mu \mathrm{m}$ filter prior to analysis of DOC, TKN, ammonia-N, and DON. DON was determined by subtracting inorganic-N from TKN.

Table 5-1. Summary of Municipal Solid Waste Landfills and Associated Leachates

\begin{tabular}{|c|c|c|c|}
\hline Landfill & Landfill Type & Leachate Samples & Sampling Location \\
\hline I & Conventional MSW & A, B, E, F, and L & Combined*: A, F, and L \\
\hline II & Conventional MSW & C & Combined* \\
\hline III & Conventional MSW & D & Combined* \\
\hline IV & Conventional MSW & G & Combined* \\
\hline V & Slurry Wall & H & Combined* \\
\hline VI & Conventional MSW & I & Combined* \\
\hline VII & Slurry Wall & J & Combined* \\
\hline VIII & Conventional MSW & K & Closed Cell \\
\hline
\end{tabular}

* Combined: Leachate from Closed and Active Cells 
Assessment of Dissolved Organic Nitrogen Bioavailability Potential using Leachate Organic

\section{Matter Chemical Properties}

The DON bioavailability to algae has been shown to be related to the chemical nature of the material. Liu et al., (2011) demonstrated that hydrophilic DON stimulated algal growth while the hydrophobic fraction did not. In our study, leachate was fractionated using solid-phase extraction (SPE) following a method by Liu et al. (2011) and adjusted for the higher concentration of organic matter (OM) present in leachate. An acrylic ester resin (Supelite DAX-8, Sigma-Aldrich) is commonly used to extract humic substances (Peuravuori et al., 2002) which are resistant to biological degradation. Resin was rinsed with $0.1 \mathrm{M} \mathrm{NaOH}$ for three days $(\mathrm{NaOH}$ was replaced every 24 hours), rinsed with methanol, and soaked in deionized (DI) water prior to use. A glass column (1.0-cm diameter, 30-cm length, Kimble-Chase) was packed with $18 \mathrm{~g}$ of conditioned resin stored in DI water. Prior to leachate additions, the columns were cleaned by flushing with 7.5 $\mathrm{L}$ of DI water. The columns were then rinsed with $2.5 \mathrm{~L}$ of $0.1 \mathrm{M} \mathrm{HCl}$ followed by $2.5 \mathrm{~L}$ of $0.1 \mathrm{M} \mathrm{NaOH}$. This step was repeated three times and then another 7.5 L of DI water were passed through the columns.

Leachate samples were filtered using a $0.45-\mu \mathrm{m}$ filter and then acidified with $12 \mathrm{~N} \mathrm{HCl}$ to a $\mathrm{pH}$ of $2.0 \mathrm{~S}$.U. prior to fractionation. A peristaltic pump was used to introduce the acidified sample through the column at a flow rate of $1 \mathrm{~mL} / \mathrm{min}$. Prior to pumping leachate through the column the samples were diluted depending on their OM content to avoid saturating the resin. Two fractions were generated: the flow-through fraction (hydrophilic; bDON) and a retained fraction (hydrophobic; rDON), as depicted in Figure 5-2. The latter fraction was eluted in the reverse direction with $0.1 \mathrm{M} \mathrm{NaOH}$. DON, COD and UV absorbance were determined for both fractions. DON was calculated by subtraction ammonia-N from TKN. 


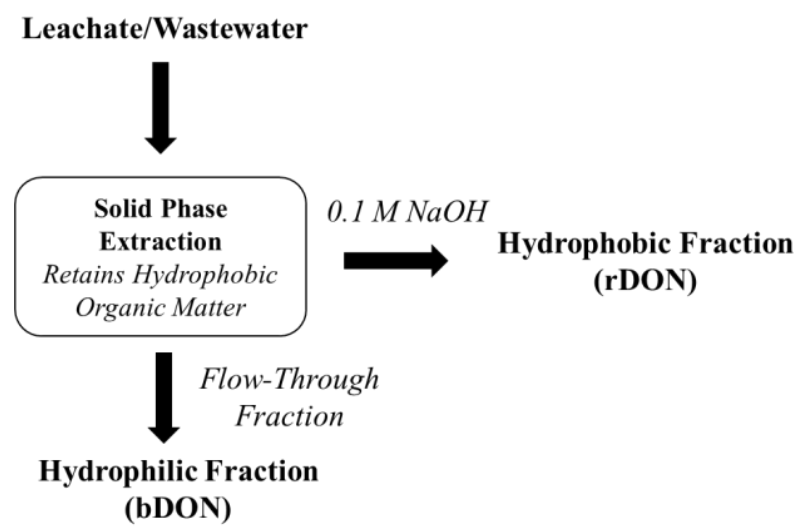

Figure 5-1. DON Fractionation Method

\section{Leachate and Wastewater Co-Treatment Simulations}

Using leachate TN, DON, and rDON data generated in this study it was possible to simulate many scenarios of leachate and wastewater co-treatment to assess the potential impact on WWTP effluents. The leachate contributions to wastewater effluent TN were estimated using a mass balance approach based on published removal efficiencies for various U.S. WWTPs (Bott and Parker, 2011). The simulations focused on TN removal for four WWTPs at four leachate volumetric contributions $(10 \%, 1 \%, 0.1 \%$, and $0.01 \%)$, and twelve leachates summarized in Table 5-1. A number of studies have reported successful co-treatment of leachate and wastewater at leachate volumetric loadings less than $~ 10-20 \%$ of influent flow (Cecen and Cakiroglu, 2001; Reinhart et al., 1994). The assumptions used in this simulation are outlined below in more detail.

WWTPs were selected based on the types of nitrogen removal processes, categorized as (1) separate stage, (2) combined, or (3) multiple stage to capture the variation in nitrogen removal by wastewater treatment technology. The selected plants utilizing separate stages for nitrogen removal achieve nitrification and denitrification in sequential processes (WWTP 1 and 2). WWTP 1 utilized an activated sludge process with denitrification filters, suspended growth 
carbonaceous biochemical oxygen demand removal and nitrification, and denitrification filters with methanol addition. WWTP 2 had a high rate activated sludge, nitrifying activated sludge, and denitrification activated sludge. When nitrification and denitrification occurred within the same sludge system, this biological unit process was considered a combined stage. An example of a combined stage biological process is a 4-stage Bardenpho (WWTP 3). The multiple-stage nitrogen removal facility (WWTP 4) would achieved nitrification and denitrification through an oxidation ditch and denitrification filters with methanol addition (Bott et al., 2012). Table 5-2 summarizes the characteristics of the WWTPs used in the simulations discussed in this paper along with their respective biological processes and influent TN concentrations without leachate. 
Table 5-2. Summary of Wastewater Treatment Plant Biological Processes and Influent TN Concentrations $^{\mathrm{a}}$

\begin{tabular}{|c|c|c|c|}
\hline & Nitrogen Removal & Biological Processes & $\begin{array}{c}\text { Average Influent } \\
\text { Wastewater TN (mg/L) }\end{array}$ \\
\hline WWTP 1 & $\begin{array}{l}\text { Separate Stage } \\
\text { Denitrification }\end{array}$ & $\begin{array}{l}\text { Activated sludge process with } \\
\text { denitrification filters, } \\
\text { suspended growth } \\
\text { carbonaceous biochemical } \\
\text { oxygen demand removal and } \\
\text { nitrification, and denitrification } \\
\text { filters with methanol addition. }\end{array}$ & 44.7 \\
\hline WWTP 2 & $\begin{array}{l}\text { Separate Stage } \\
\text { Denitrification }\end{array}$ & $\begin{array}{l}\text { High rate activated sludge, } \\
\text { nitrifying activated sludge, and } \\
\text { denitrification activated sludge. }\end{array}$ & 25.5 \\
\hline WWTP 3 & $\begin{array}{l}\text { Combined Stage } \\
\text { (Single Sludge } \\
\text { System) }\end{array}$ & 4-stage Bardenpho & 24.5 \\
\hline WWTP 4 & $\begin{array}{l}\text { Multiple Stage for } \\
\text { Nitrification and } \\
\text { Denitrification }\end{array}$ & $\begin{array}{c}\text { Oxidation ditch and } \\
\text { denitrification filters with } \\
\text { methanol addition }\end{array}$ & 60.0 \\
\hline
\end{tabular}

a. Adapted from Bott et al., 2012

b. TN without Leachate Contributions

The TN removal efficiencies of four WWTPs and their summary statistics $\left(50^{\text {th }}, 95^{\text {th }}\right.$, and $99^{\text {th }}$ percentiles) for daily performance based on historical plant data over a three-year period were published by Bott et al. (2012). The $95^{\text {th }}$ percentile is considered to capture the "reliable" achievable performance for a WWTP (Bott et al., 2012) by definition. The median is used in this analysis rather than the average since the latter can be more greatly influenced by erratic values. Removal efficiencies will depend on the available technology at the WWTP, climate, and frequency of mechanical failures. The removal efficiencies for each WWTP are presented in Tables 5-3 through 5-6. In terms of meeting permit limits removal efficiencies in the $50^{\text {th }}, 95^{\text {th }}$, and $99^{\text {th }}$ percentiles would yield approximately 183,18 , and 4 daily exceedances over the course of one year (Bott and Parker, 2011). 
The removal of leachate DON is not well understood in wastewater treatment however it is assumed that leachate rDON is not removed. Two leachate bDON removals were evaluated (1) no removal of bDON (Equation 5-1) and (2) removal of bDON at the same rate of TN for each WWTP (Equation 5-2). In Equation 5-1, DON was removed from the leachate TN since it was assumed to pass through the biological treatment process. The DON was then added back to the remaining TN after taking into account the TN removal efficiency. In Equation 5-1, it was assumed that bDON removal was equivalent to the wastewater TN efficiencies. Therefore only rDON was subtracted from the leachate TN prior to the removal calculations. Only rDON was added back to the effluent TN.

$$
\begin{gathered}
T N_{1}=\frac{\left(\left[\left(T N_{W W} \times \frac{V_{W W}}{V_{W W}+V_{L}}\right)+\left(\left(T N_{\text {Leac hate }}-D O N_{L}\right) \times \frac{V_{L}}{V_{W W}+V_{L}}\right)\right]\right) \times T N_{\text {Removal }}+D O N_{L} \times \frac{V_{L}}{V_{W W}+V_{L}}}{V_{W W}+V_{L}} \\
T N_{2}=\frac{\left(\left[\left(T N_{W W} \times \frac{V_{W W}}{V_{W W}+V_{L}}\right)+\left(\left(T N_{\text {Leac hate }}-r D O N_{L}\right) \times \frac{V_{L}}{V_{W W}+V_{L}}\right)\right]\right) \times T N_{\text {Removal }}+r D O N_{L} \times \frac{V_{L}}{V_{W W}+V_{L}}}{V_{W W}+V_{L}}
\end{gathered}
$$

These calculations were carried out for each leachate and volumetric contribution (10\%, $1.0 \%, 0.1 \%$, and $0.01 \%$ ). These simulations will allow for a conservative estimation of the range of leachate impacts on effluent quality in terms of TN, rDON, and DON. The nitrogen removal efficiencies for each WWTP is outlined in Tables 5-3 through 5-6. The scenario where bDON is not removed is not outlined. The removal efficiency would be dilution only. 
Table 5-3. Summary of Removal Efficiencies for Nitrogen Species for WWTP 1

\begin{tabular}{|c|c|c|c|}
\hline Parameter & $\begin{array}{c}\text { Removal Efficiency } \\
50^{\text {th }} \text { Percentile }\end{array}$ & $\begin{array}{c}\text { Removal Efficiency } \\
95^{\text {th }} \text { Percentile }\end{array}$ & $\begin{array}{c}\text { Removal Efficiency } \\
99^{\text {th }} \text { Percentile }\end{array}$ \\
\hline Leachate rDON & Dilution Only & Dilution Only & Dilution Only \\
\hline Leachate bDON & $97 \%$ & $93 \%$ & $91 \%$ \\
\hline $\begin{array}{c}\text { Ammonia-N + NOx (WW } \\
\text { and Leachate) }\end{array}$ & $97 \%$ & $93 \%$ & $91 \%$ \\
\hline
\end{tabular}

Table 5-4. Summary of Removal Efficiencies for Nitrogen Species for WWTP 2

\begin{tabular}{|c|c|c|c|}
\hline Parameter & $\begin{array}{c}\text { Removal Efficiency } \\
50^{\text {th }} \text { Percentile }\end{array}$ & $\begin{array}{c}\text { Removal Efficiency } \\
95^{\text {th }} \text { Percentile }\end{array}$ & $\begin{array}{c}\text { Removal Efficiency } \\
9^{\text {th }} \text { Percentile }\end{array}$ \\
\hline Leachate rDON & Dilution Only & Dilution Only & Dilution Only \\
\hline Leachate bDON & $94 \%$ & $87 \%$ & $76 \%$ \\
\hline $\begin{array}{c}\text { Ammonia-N + NOx (WW } \\
\text { and Leachate) }\end{array}$ & $94 \%$ & $87 \%$ & $76 \%$ \\
\hline
\end{tabular}

Table 5-5. Summary of Removal Efficiencies for Nitrogen Species for WWTP 3

\begin{tabular}{|c|c|c|c|}
\hline Parameter & $\begin{array}{c}\text { Removal Efficiency } \\
50^{\text {th }} \text { Percentile }\end{array}$ & $\begin{array}{c}\text { Removal Efficiency } \\
95^{\text {th }} \text { Percentile }\end{array}$ & $\begin{array}{c}\text { Removal Efficiency } \\
99^{\text {th }} \text { Percentile }\end{array}$ \\
\hline Leachate rDON & Dilution Only & Dilution Only & Dilution Only \\
\hline Leachate bDON & $86 \%$ & $74 \%$ & $58 \%$ \\
\hline $\begin{array}{c}\text { Ammonia-N + NOx (WW } \\
\text { and Leachate) }\end{array}$ & $86 \%$ & $74 \%$ & $58 \%$ \\
\hline
\end{tabular}

Table 5-6. Summary of Removal Efficiencies for Nitrogen Species for WWTP 4

\begin{tabular}{|c|c|c|c|}
\hline Parameter & $\begin{array}{c}\text { Removal Efficiency } \\
50^{\text {th }} \text { Percentile }\end{array}$ & $\begin{array}{c}\text { Removal Efficiency } \\
95^{\text {th }} \text { Percentile }\end{array}$ & $\begin{array}{c}\text { Removal Efficiency } \\
99^{\text {th }} \text { Percentile }\end{array}$ \\
\hline Leachate rDON & Dilution Only & Dilution Only & Dilution Only \\
\hline Leachate bDON & $98 \%$ & $95 \%$ & $94 \%$ \\
\hline $\begin{array}{c}\text { Ammonia-N + NOx (WW } \\
\text { and Leachate) }\end{array}$ & $98 \%$ & $95 \%$ & $94 \%$ \\
\hline
\end{tabular}




\section{$\underline{\text { Results and Discussion }}$}

\section{Quantification of Leachate Recalcitrant Dissolved Organic Nitrogen}

Samples collected from the eight landfills (twelve leachate samples) yielded a wide variation of values for the leachate parameters, as provided in Appendix E (Table E-3). Some of the observed differences can be attributed to landfill operation (e.g., conventional liner system vs. slurry wall, age of the landfill, climate). The average concentration of TN and DON in leachate was approximately $1,160 \mathrm{mg} / \mathrm{L}$ and $40.7 \mathrm{mg} / \mathrm{L}$, respectively (Table 5-7).

Table 5-7. Summary of Leachate Total Nitrogen and Dissolved Organic Nitrogen

\begin{tabular}{|c|c|c|}
\hline & Total Nitrogen $(\mathrm{mg} / \mathrm{L})$ & DON $(\mathrm{mg} / \mathrm{L})$ \\
\hline Leachate $\mathrm{A}$ & 824 & 22 \\
\hline Leachate B & 1936 & 53 \\
\hline Leachate C & 916 & 31 \\
\hline Leachate $\mathrm{E}$ & 1854 & 97 \\
\hline Leachate $\mathrm{F}$ & 1470 & 25 \\
\hline Leachate $\mathrm{G}$ & 939 & 56 \\
\hline Leachate $\mathrm{H}$ & 216 & 15.5 \\
\hline Leachate I & 2100 & 90 \\
\hline Leachate J & 224.5 & 14 \\
\hline Leachate $\mathrm{K}$ & 806 & 10 \\
\hline Leachate $\mathrm{L}$ & 2440 & 60 \\
\hline Leachate $\mathrm{M}$ & 522 & 20 \\
\hline Leachate $\mathrm{N}$ & 818 & 36 \\
\hline Average & 1,160 & 40.7 \\
\hline Maximum & 2,440 & 97.0 \\
\hline Minimum & 216 & 10.0 \\
\hline
\end{tabular}

The distribution of bDON and $\mathrm{rDON}$ in the twelve leachates analyzed is presented in Figure 5-2. The average concentrations of bDON and $\mathrm{rDON}$ were $16.5 \mathrm{mg} / \mathrm{L}$ and $18.4 \mathrm{mg} / \mathrm{L}$, respectively. The average recovery of DON for the studied leachates was $87 \%$ determined by 
comparing the sum of bDON and rDON concentrations to the DON prior to fractionation. rDON accounted for over $60 \%$ of the DON found in leachates B, H, K, and L. These leachates were collected from closed (i.e., older) landfills cells. The remaining leachates had lower rDON fractions and were collected from lift stations. These leachates were representative of both closed and active landfill cells and would be influenced by younger leachates. Bulk leachate characteristics (Table E-1) were compared to rDON and bDON concentrations to determine whether any parameters were correlated. bDON did not correlate strongly with any leachate characteristics. rDON was positively correlated, but had low $\mathrm{R}^{2}$ values, with apparent color and humic acid.

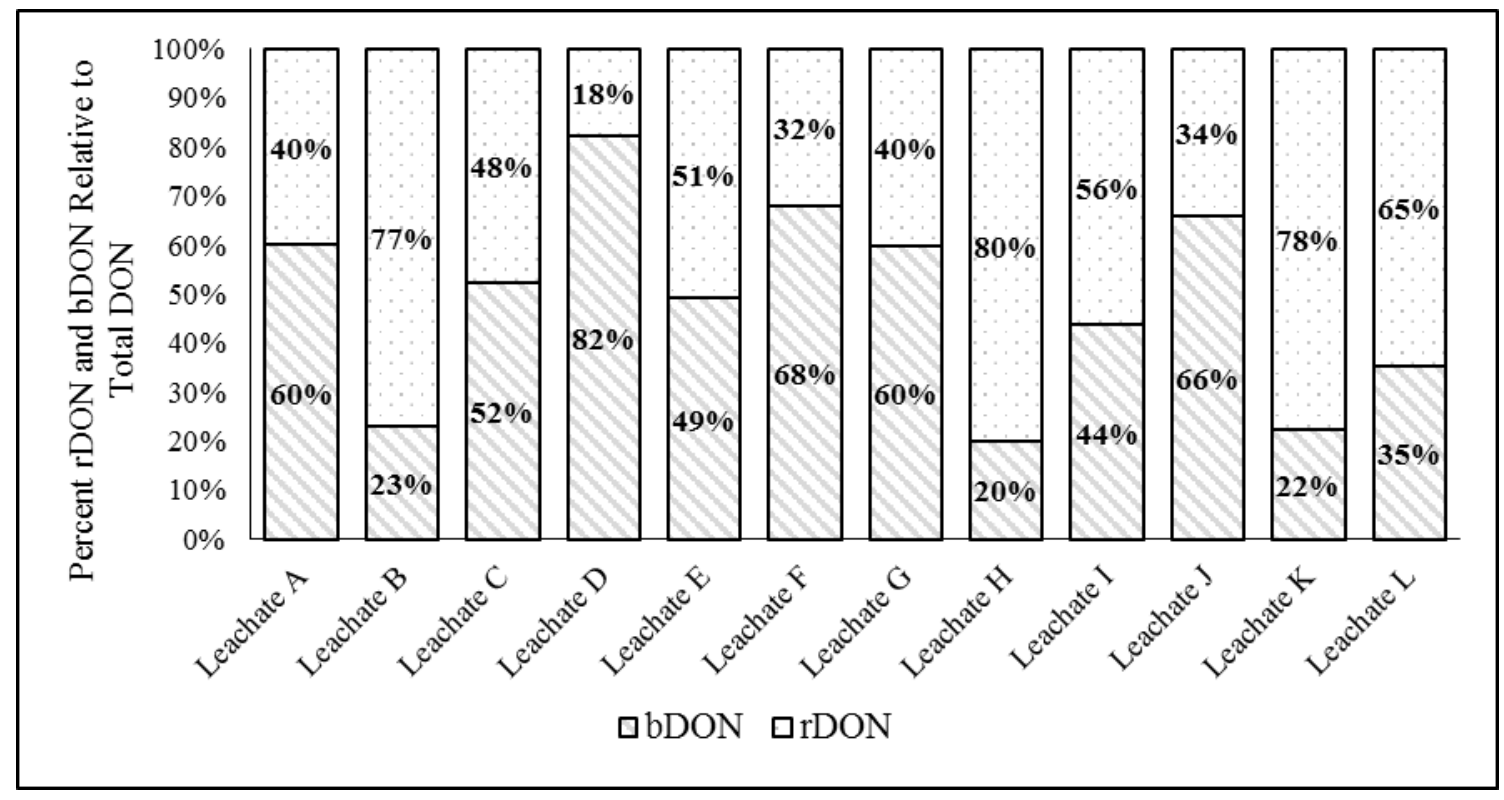

Figure 5-2. Distribution of bDON and rDON Fractions in Leachate

The bDON and rDON fractions were characterized for color, COD, and UV absorbance at $254 \mathrm{~nm}, 465 \mathrm{~nm}$, and $665 \mathrm{~nm}$ (Table 5-8). Significant differences were observed between the two fractions. The hydrophilic fraction of DON (rDON) was highly colored and represented over $60 \%$ of the total leachate COD. This fraction has higher $\mathrm{UV}_{254 \mathrm{~nm}}$ absorbance, relative to bDON, 
which correlated well with the concentration of rDON. A study by Zhang et al., (2000) identified the hydrophobic DON as the nitrogen bound to functional groups of humic substances. Kang et al. (2002) found that the ratio of UV absorption at $465 \mathrm{~nm}$ to that at $665 \mathrm{~nm}$ for aquatic samples is related to aromaticity of organic matter and inversely proportional to molecular weight of the organic matter. It was observed that $\mathrm{rDON}$ exhibited a higher $\mathrm{E}_{4} / \mathrm{E}_{6}$ ratio relative to hydrophilic fraction suggesting that hydrophobic OM, including rDON, consisted of lower molecular weight organic matter.

Table 5-8. Summary of bDON and rDON Properties of the Fractionated Leachate Samples

\begin{tabular}{|c|c|c|c|c|c|c|c|c|}
\hline & \multicolumn{4}{|c|}{ bDON Properties } & \multicolumn{3}{c|}{ rDON Properties } \\
\hline Parameter & $\begin{array}{c}\text { Color } \\
(\mathrm{pt-Co} \text { units) }\end{array}$ & $\begin{array}{c}\mathrm{COD} \\
(\mathrm{mg} / \mathrm{L})\end{array}$ & $\begin{array}{c}\mathrm{UV}_{254} \\
(\mathrm{abs})\end{array}$ & $\begin{array}{c}\mathrm{E}_{4} / \mathrm{E}_{6} \\
(\mathrm{unitless})\end{array}$ & $\begin{array}{c}\text { Color } \\
(\mathrm{pt}-\text { Co units })\end{array}$ & $\begin{array}{c}\text { COD } \\
(\mathrm{mg} / \mathrm{L})\end{array}$ & $\begin{array}{c}\mathrm{UV}_{254} \\
(\mathrm{abs})\end{array}$ & $\begin{array}{c}\mathrm{E}_{4} / \mathrm{E}_{6} \\
(\mathrm{unitless})\end{array}$ \\
\hline Leachate A & 8.59 & 825 & 3.93 & 3.00 & 4630 & 1530 & 16.3 & 12.17 \\
\hline Leachate B & 45.6 & 1250 & 10.5 & 6.00 & 18500 & 2219 & 68.8 & 4.00 \\
\hline Leachate C & 8.59 & 1680 & 3.98 & 6.00 & 923 & 2800 & 11.4 & 18.00 \\
\hline Leachate D & 34.5 & 168 & 0.69 & 9.00 & 923 & 384 & 41.6 & 14.00 \\
\hline Leachate $\mathrm{E}$ & 16.0 & 1290 & 6.23 & 4.00 & 11200 & 2000 & $\mathrm{ND}$ & 8.72 \\
\hline Leachate F & 60.4 & 188 & 9.34 & 5.00 & 1870 & 672 & 66.0 & 13.33 \\
\hline Leachate G & 49.3 & 122 & 5.74 & 4.33 & 1140 & 468 & 33.1 & 12.50 \\
\hline Leachate H & 23.4 & 31 & 1.79 & 6.00 & 38.2 & 101 & 4.95 & 9.67 \\
\hline Leachate I & 194 & 695 & 2.56 & 3.69 & 2220 & 1770 & 67.8 & 10.50 \\
\hline Leachate J & 149 & 155 & 1.05 & 4.63 & 1630 & 818 & 10.2 & 8.00 \\
\hline Leachate K & 172 & 375 & 2.80 & 5.86 & 5480 & 1790 & 30 & 9.50 \\
\hline Leachate L & 120 & 975 & 2.76 & 4.00 & 8290 & 5800 & 115 & 12.75 \\
\hline
\end{tabular}

ND: No Data

\section{Impact of Leachate Co-Treatment on Wastewater Effluent Quality}

Tables 5-9 and 5-10 summarize the minimum, maximum, average, and standard deviation TN effluent concentrations for the WWTP simulations. Values exceeding typical effluents limits of $3 \mathrm{mg} / \mathrm{L}$ and $10 \mathrm{mg} / \mathrm{L}$ of TN are highlighted in Tables 5-4 and 5-5. Exceedances for both discharge limits were found for leachate contributions of $10 \%$ based on all three performance 
statistics and the two bDON removal scenarios. A high number of values exceeded $10 \mathrm{mg} / \mathrm{L}$ at lower leachate volumetric contributions at the $95^{\text {th }}$ and $99^{\text {th }}$ percentiles was observed in Tables 59 and 5-10. This trend is attributed to the fluctuations in plant performance at the poor removal efficiencies captured by the $95^{\text {th }}$ and $99^{\text {th }}$ percentiles. Consequently, there are scenarios where consistently achieving TN concentrations of less than $10 \mathrm{mg} / \mathrm{L}$, even at low leachate volumetric contributions, is not possible. A plant operating at the $50^{\text {th }}$ percentile would be the only scenario where leachate could be accepted at a volumetric contribution of $1.0 \%$ and lower and still achieve TN concentrations of less than $10 \mathrm{mg} / \mathrm{L}$. A more detailed analysis on a case by case basis would need to be completed for WWTPs required to meet TN limits of $3 \mathrm{mg} / \mathrm{L}$ or lower when receiving leachate.

Table 5-9. Summary of Wastewater Effluent Total Nitrogen as a Function of Leachate Volumetric Loadings and Fluctuations in Daily Plant Performance (bDON Removal is Equivalent to $\mathrm{TN}$ )

\begin{tabular}{|c|c|c|c|c|c|c|c|c|c|c|c|c|}
\hline \multirow{3}{*}{$\begin{array}{l}\text { Volumetric } \\
\text { Contribution } \\
\text { of Leachate }\end{array}$} & \multicolumn{4}{|c|}{$\begin{array}{l}\text { WWTPs Operating at } \mathbf{5 0}^{\text {th }} \\
\text { Percentile for TN Removal }\end{array}$} & \multicolumn{4}{|c|}{$\begin{array}{l}\text { WWTPs Operating at } 95^{\text {th }} \\
\text { Percentile for TN Removal }\end{array}$} & \multicolumn{4}{|c|}{$\begin{array}{l}\text { WWTPs Operating at } 99^{\text {th }} \\
\text { Percentile for TN Removal }\end{array}$} \\
\hline & \multicolumn{4}{|c|}{ Total Nitrogen (mg/L) } & \multicolumn{4}{|c|}{ Total Nitrogen $(\mathrm{mg} / \mathrm{L})$} & \multicolumn{4}{|c|}{ Total Nitrogen (mg/L) } \\
\hline & Min & Max & Average & $\begin{array}{l}\text { Standard } \\
\text { Deviation } \\
\end{array}$ & Min & Max & Average & $\begin{array}{l}\text { Standard } \\
\text { Deviation } \\
\end{array}$ & Min & $\operatorname{Max}$ & Average & $\begin{array}{l}\text { Standard } \\
\text { Deviation }\end{array}$ \\
\hline $10 \%$ & 4.71 & 20.6 & 10.4 & 7.04 & 9.38 & 37.1 & 19.3 & 12.51 & 12.6 & 58.5 & 30.6 & 20.88 \\
\hline $1 \%$ & 1.40 & 5.11 & 2.70 & 1.65 & 3.38 & 9.47 & 5.36 & 2.80 & 4.73 & 15.1 & 8.61 & 4.71 \\
\hline $0.01 \%$ & 1.03 & 3.42 & 1.85 & 1.07 & 2.72 & 6.43 & 3.82 & 1.75 & 3.87 & 10.4 & 6.19 & 2.94 \\
\hline
\end{tabular}

\section{$3 \mathrm{mg} / \mathrm{L} \quad \square 10 \mathrm{mg} / \mathrm{L}$}


Table 5-10. Summary of Wastewater Effluent Total Nitrogen as a Function of Leachate Volumetric Loadings and Daily Plant Performance (No Removal of DON)

\begin{tabular}{|c|c|c|c|c|c|c|c|c|c|c|c|c|}
\hline \multirow{3}{*}{$\begin{array}{c}\text { Volumetric } \\
\text { Contribution } \\
\text { of Leachate }\end{array}$} & \multicolumn{4}{|c|}{$\begin{array}{l}\text { WWTPs Operating at } 50^{\text {th }} \\
\text { Percentile for TN Removal }\end{array}$} & \multicolumn{4}{|c|}{$\begin{array}{l}\text { WWTPs Operating at } 95^{\text {th }} \\
\text { Percentile for TN Removal }\end{array}$} & \multicolumn{4}{|c|}{$\begin{array}{l}\text { WWTPs Operating at } 99^{\text {th }} \\
\text { Percentile for TN Removal }\end{array}$} \\
\hline & \multicolumn{4}{|c|}{ Total Nitrogen (mg/L) } & \multicolumn{4}{|c|}{ Total Nitrogen (mg/L) } & \multicolumn{4}{|c|}{ Total Nitrogen (mg/L) } \\
\hline & Min & Max & Average & $\begin{array}{l}\text { Standard } \\
\text { Deviation }\end{array}$ & Min & Max & Average & $\begin{array}{l}\text { Standard } \\
\text { Deviation }\end{array}$ & Min & Max & Average & $\begin{array}{l}\text { Standard } \\
\text { Deviation }\end{array}$ \\
\hline $10 \%$ & 6.79 & 22.37 & 12.42 & 6.93 & 11.40 & 38.62 & 21.14 & 12.30 & 11.61 & 39.97 & 21.86 & 12.81 \\
\hline $1 \%$ & 1.61 & 5.30 & 2.90 & 1.64 & 3.58 & 9.62 & 5.54 & 2.78 & 3.69 & 10.05 & 5.79 & 2.92 \\
\hline $0.1 \%$ & 1.09 & 3.59 & 1.94 & 1.12 & 2.80 & 6.72 & 3.98 & 1.84 & 2.89 & 7.06 & 4.18 & 1.94 \\
\hline $0.01 \%$ & 1.04 & 3.42 & 1.85 & 1.07 & 2.72 & 6.43 & 3.82 & 1.75 & 2.81 & 6.76 & 4.02 & 1.84 \\
\hline
\end{tabular}

\section{$3 \mathrm{mg} / \mathrm{L} \square 10 \mathrm{mg} / \mathrm{L}$}

On average, DON and rDON of the leachate were $4.6 \%$ and $2.39 \%$ of TN, respectively. This information was used to determine the hypothetical TN that could be accepted at the four WWTPs without exceeding $3 \mathrm{mg} / \mathrm{L}$ and $10 \mathrm{mg} / \mathrm{L}$ of TN. The maximum leachate TN concentrations at a volumetric contribution of $10 \%$ that can be accepted at the WWTPs are summarized in Table 5-11. WWTP 3 has the lowest leachate TN that could be accepted because of the inefficiency of the combined-stage biological process for nitrogen removal. Regardless of the removal percentile, WWTP 3 would not be able to accept leachate represented by the twelve samples in this study and meet a $3.0 \mathrm{mg} / \mathrm{L}$ of $\mathrm{TN}$.

Table 5-11. Maximum Allowable Leachate Total Nitrogen Concentration without Exceeding TN Effluent Limits (Partial bDON Removal)

\begin{tabular}{|c|c|c|c|c|c|c|}
\hline & \multicolumn{3}{|c|}{$10 \mathrm{mg} / \mathrm{L}$ Limit } & \multicolumn{3}{c|}{$3 \mathrm{mg} / \mathrm{L}$ Limit } \\
\cline { 2 - 7 } & $50^{\text {th }}$ & $95^{\text {th }}$ & $99^{\text {th }}$ & $50^{\text {th }}$ & $95^{\text {th }}$ & $99^{\text {th }}$ \\
\hline WWTP 1 & 1565 & 840 & 506 & 305 & 42 & No Leachate \\
\hline WWTP 2 & 1082 & 486 & 172 & 209 & 8 & No Leachate \\
\hline WWTP 3 & 435 & 152 & 16 & No Leachate & No Leachate & No Leachate \\
\hline WWTP 4 & 2230 & 1100 & 753 & 510 & 83 & No Leachate \\
\hline
\end{tabular}

No Leachate: No additional nitrogen from leachate could be accepted 
Table 5-12. Maximum Allowable Leachate Total Nitrogen Concentration without Exceeding TN Effluent Limits (Dilution Only)

\begin{tabular}{|c|c|c|c|c|c|c|}
\hline & \multicolumn{3}{|c|}{$10 \mathrm{mg} / \mathrm{L}$ Limit } & \multicolumn{3}{c|}{$3 \mathrm{mg} / \mathrm{L}$ Limit } \\
\cline { 2 - 7 } & $50^{\text {th }}$ & $95^{\text {th }}$ & $99^{\text {th }}$ & $50^{\text {th }}$ & $95^{\text {th }}$ & $99^{\text {th }}$ \\
\hline WWTP 1 & 1130 & 680 & 434 & 220 & 34 & No Leachate \\
\hline WWTP 2 & 859 & 429 & 162 & 166 & 7 & No Leachate \\
\hline WWTP 3 & 389 & 143 & 16 & No Leachate & No Leachate & No Leachate \\
\hline WWTP 4 & 1450 & 849 & 608 & 332 & 63 & No Leachate \\
\hline
\end{tabular}

No Leachate: No additional nitrogen from leachate could be accepted

Typical WWTP permits only require reporting of effluent $\mathrm{TN}$, ammonia-N, and nitrate/nitrite-N concentrations. Quantifying the recalcitrant fraction of TN may be important, particularly if a WWTP permit is required to meet low TN limits. The calculated rDON pass through at $10 \%$ and $1 \%$ volumetric contributions for the tested leachates assuming no removal ranged from $0.0435-4.77 \mathrm{mg} / \mathrm{L}$ and $0.00435-0.477 \mathrm{mg} / \mathrm{L}$, respectively. The calculated DON pass through at $10 \%$ and $1 \%$ volumetric contributions for the tested leachates assuming no removal ranged from $0.266-9.71 \mathrm{mg} / \mathrm{L}$ and $0.0266-0.971 \mathrm{mg} / \mathrm{L}$, respectively. Production of DON was not accounted for in this analysis.

Out of the twelve studied leachate, three samples contributed to an estimated rDON pass through of greater than $3 \mathrm{mg} / \mathrm{L}$ at a $10 \%$ volumetric contribution (Figure 5-6). None of the samples exceeded $10 \mathrm{mg} / \mathrm{L}$ but, on average, rDON could account for approximately $18 \%$ of this TN concentration (Figure 5-3). At a volumetric contribution of $1 \%$, none of the samples exceeded $1 \mathrm{mg} / \mathrm{L}$ (Figure 5-4).

DON had a significant effect on TN as $50 \%$ of the studied leachates exceeded $3 \mathrm{mg} / \mathrm{L}$, respectively, at a 10\% volumetric contribution (Figure 5-4). DON never exceeded $10 \mathrm{mg} / \mathrm{L}$. On average leachate DON accounted for $40 \%$ of the $10 \mathrm{mg} / \mathrm{L}$ of TN concentration. Therefore it would be expected that discharging leachate at a $1 \%$ or less by volume would not significantly impact the TN effluent limits in terms of rDON and DON. 


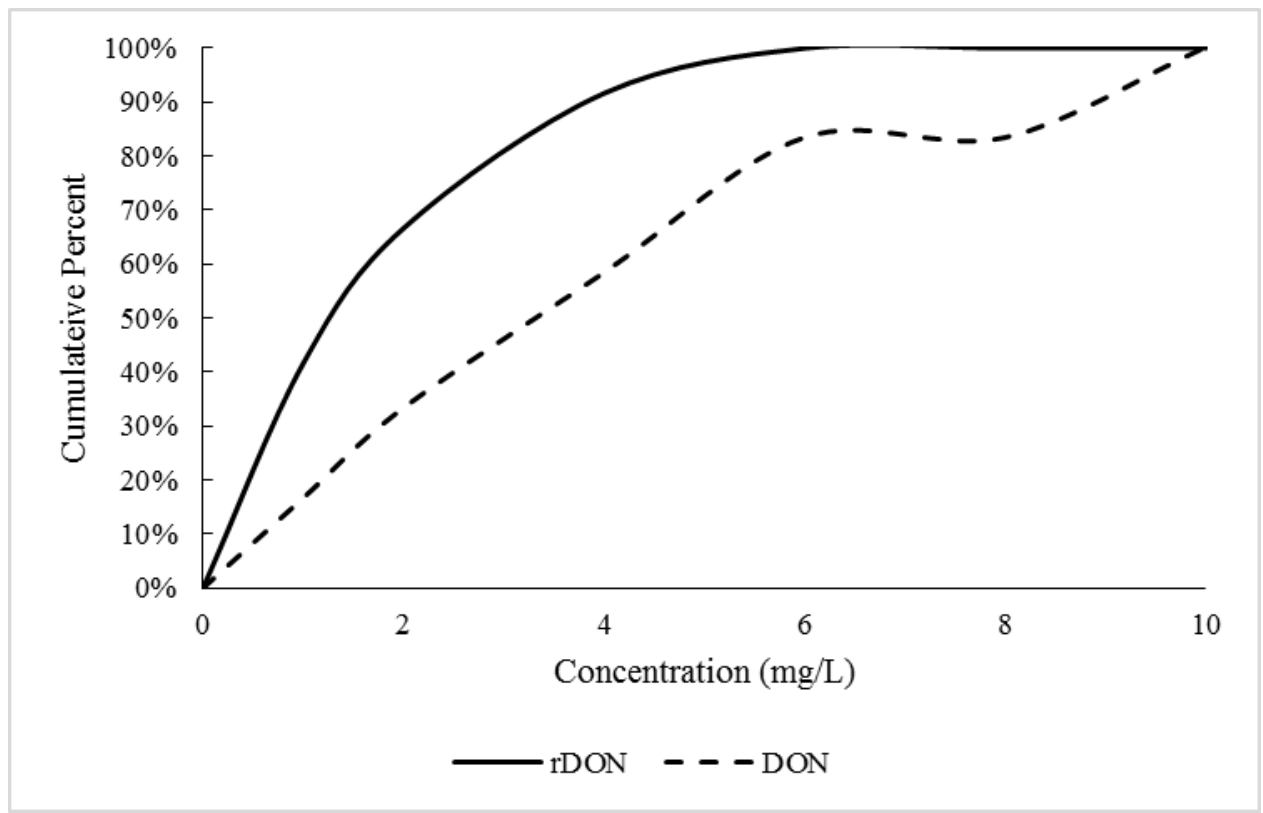

Figure 5-3. Cumulative Frequency of rDON and DON Concentration in Wastewater Effluent at a Leachate Volumetric Contribution of $10 \%$

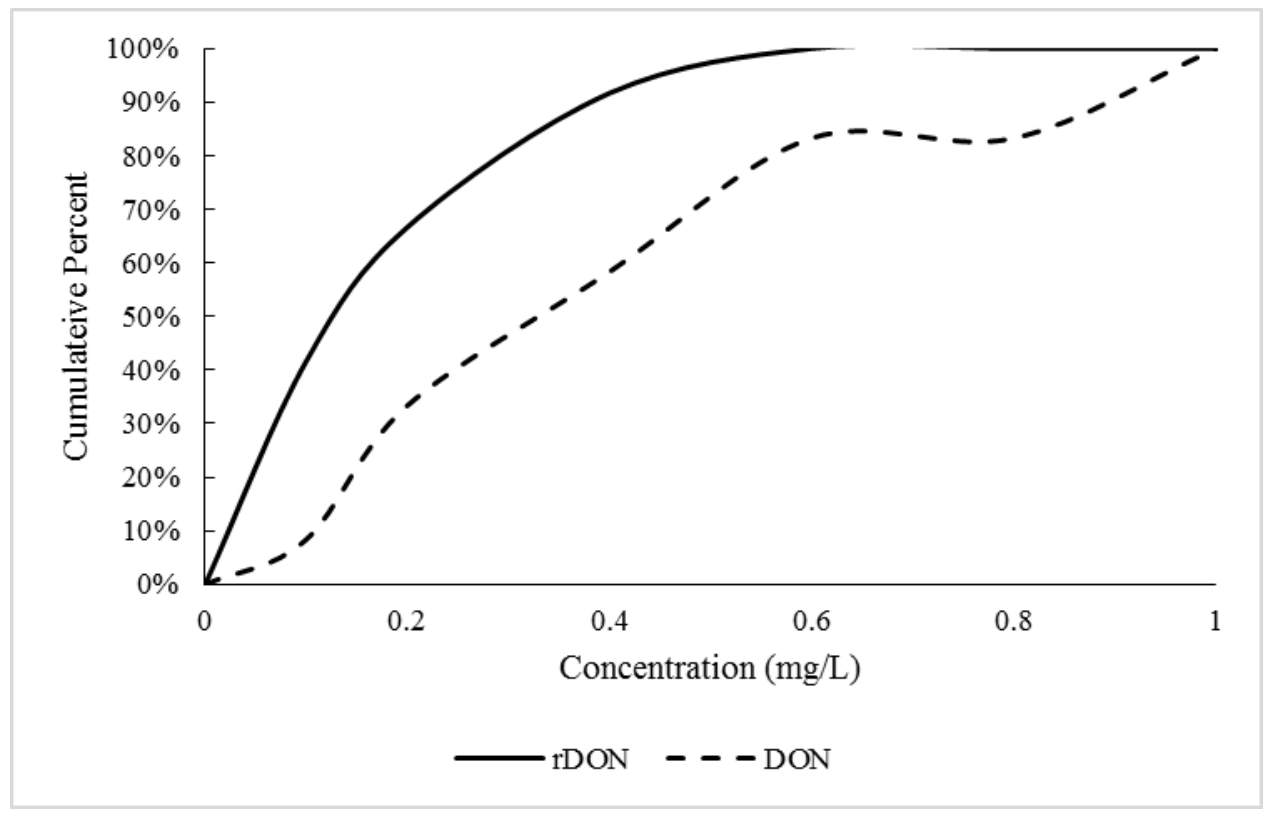

Figure 5-4. Cumulative Frequency of rDON and DON Concentration in Wastewater Effluent at a Leachate Volumetric Contribution of $1 \%$ 
The fate of rDON and DON brings to light concerns that these nitrogen species could contribute to nutrient impairment of waterbodies at leachate volumetric contributions greater than 1\%. A study by Bushaw-Newton and Moran (1999) found that $6 \%$ of the nitrogen associated with humic substances became bioavailable after natural solar radiation for one day. Photochemical modifications to humic substances promoted the production of labile nitrogen species in their study. These species included primary amines, ammonia-N, and other compounds yet to be identified. Further studies are needed to quantify the production of labile nitrogen following the discharge of rDON and bDON to aquatic systems.

\section{$\underline{\text { Conclusion }}$}

This study provided data on the concentrations of TN and DON in leachate and the breakdown of rDON and bDON based on hydrophilic and hydrophobic properties. The average concentrations of TN and DON in sampled leachates were approximately $1,160 \mathrm{mg} / \mathrm{L}$ and 40.7 $\mathrm{mg} / \mathrm{L}$, respectively. The average concentrations of bDON and rDON were $16.5 \mathrm{mg} / \mathrm{L}$ and 18.4 $\mathrm{mg} / \mathrm{L}$, respectively. Understanding the distribution of each fraction relative to leachate characteristics was important to estimate the potential treatability of landfill leachate in WWTP and pass through to the environment. It was observed that at a $10 \%$ volumetric contribution, typical WWTPs were able to meet a TN discharge limit of $10 \mathrm{mg} / \mathrm{L}$ but not $3 \mathrm{mg} / \mathrm{L}$. Simulations showed that the pass through of leachate DON was significant and could lead to exceedances of $\mathrm{TN}$ limits less than $10 \mathrm{mg} / \mathrm{L}$. There is potential, based on the literature, for these nitrogen species to become bioavailable once discharged to aquatic systems. Treatment of leachate can reduce nitrogen loadings to WWTPs and the discharge to aquatic systems. 


\section{Acknowledgements}

We would like to acknowledge the contributions of Duncan Lozinski from the University of Central Florida for his work in laboratory and Dr. Barbara Cottrell for collecting leachate from the California Landfill. This material is based upon work supported by the Hinkley Center for Solid and Hazardous Waste Management, Environmental Research and Education Foundation, and the National Science Foundation (\#1311037). 


\section{$\underline{\text { References }}$}

APHA. (2005). Standard Methods for the Examination of Water and Wastewater.

Batarseh, Reinhart, D., \& Daly, L. (2007a). Liquid Sodium Ferrate and Fenton's Reagent for Treatment of Mature Landfill Leachate. Journal of Environmental Engineering, 133(11), 1042-1050. doi: doi:10.1061/(ASCE)0733-9372(2007)133:11(1042)

Batarseh, E., Reinhart, D., \& Daly, L. (2007b). Liquid Sodium Ferrate and Fenton's Reagent for Treatment of Mature Landfill Leachate. Journal of Environmental Engineering, 133(11), 1042-1050. doi: doi:10.1061/(ASCE)0733-9372(2007)133:11(1042)

Bott, C. B., \& Parker, D. S. (2011). WEF/WERF Study Quantifying Nutrient Removal Technology Performance.

Bott, C. B., Parker, D. S., Jimenez, J., Miller, M. W., \& Neethling, J. B. (2012). WEF/WERF study of BNR plants achieving very low $\mathrm{N}$ and $\mathrm{P}$ limits: evaluation of technology performance and process reliability. Water Science and Technology, 65(5), 808-815.

Bushaw-Newton, K., L. , \& Moran, M. A. (1999). Photochemical formation of biologically available nitrogen from dissolved humic substances in coastal marine systems. Aquatic Microbial Ecology, 18(3), 285-292.

Bushaw, K. L., Zepp, R. G., Tarr, M. A., Schulz-Jander, D., Bourbonniere, R. A., Hodson, R. E., ... Moran, M. A. (1996). Photochemical release of biologically available nitrogen from aquatic dissolved organic matter. Nature, 381(6581), 404-407.

Cecen, F., \& Cakiroglu, D. (2001). Impact of landfill leachate on the co-treatment of domestic wastewater. Biotechnology Letters(9), 821.

Chesapeake Bay Foundation. (2003). Sewage Treatment Plants: The Chesapeake Bay Watershed's Second Largest Source of Nitrogen Pollution.

Cortez, S., Teixeira, P., Oliveira, R., \& Mota, M. (2011). Evaluation of Fenton and ozone-based advanced oxidation processes as mature landfill leachate pre-treatments. Journal of Environmental Management, 92(3), 749-755. doi: http://dx.doi.org/10.1016/j.jenvman.2010.10.035

Dotson, A., Westerhoff, P., \& Krasner, S. W. (2009). Nitrogen enriched dissolved organic matter (DOM) isolates and their affinity to form emerging disinfection by-products (Vol. 60): Water Science \& Technology.

EPA, U. S. (2015). State Development of Numeric Criteria for Nitrogen and Phosphorus Pollution. Retrieved 2/20/2016, from http://cfpub.epa.gov/wqsits/nnc-development/

Kang, K.-H., Shin, H. S., \& Park, H. (2002). Characterization of humic substances present in landfill leachates with different landfill ages and its implications. Water Research, 36(16), 4023-4032. doi: http://dx.doi.org/10.1016/S0043-1354(02)00114-8

Liu, H., Jeong, J., Gray, H., Smith, S., \& Sedlak, D. L. (2011). Algal Uptake of Hydrophobic and Hydrophilic Dissolved Organic Nitrogen in Effluent from Biological Nutrient Removal Municipal Wastewater Treatment Systems. Environmental Science \& Technology, 46(2), 713-721. doi: 10.1021/es203085y

Matthews, R., Sharp, R., \& Pitt, P. (2011). Florida's Numeric Nutrient Criteria and the Potential Importance of Dissolved Organic Nitrogen. Paper presented at the Water Environment Federation: Nutrient Management, Miami, Florida.

Mitch, W. A., Gerecke, A. C., \& Sedlak, D. L. (2003). A N-Nitrosodimethylamine (NDMA) precursor analysis for chlorination of water and wastewater. Water Research, 37(15), 3733-3741. doi: http://dx.doi.org/10.1016/S0043-1354(03)00289-6 
Morris, J. W. F., Vasuki, N. C., Baker, J. A., \& Pendleton, C. H. (2003). Findings from longterm monitoring studies at MSW landfill facilities with leachate recirculation. Waste Management, 23(7), 653-666. doi: http://dx.doi.org/10.1016/S0956-053X(03)00098-9

Peuravuori, J., Lehtonen, T., \& Pihlaja, K. (2002). Sorption of aquatic humic matter by DAX-8 and XAD-8 resins: Comparative study using pyrolysis gas chromatography. Analytica Chimica Acta, 471(2), 219-226. doi: http://dx.doi.org/10.1016/S0003-2670(02)00931-5

Reinhart, D., \& Bolyard, S. C. (2015). Fate of Organic Matter from Leachate Discharged to Wastewater Treatment Plants (Year 1). Hinkley Center for Solid and Hazardous Waste Management.

Reinhart, D. R., Dietz, J. D., Tunnell, L. G., \& Christodoulou, A. (1994). Landfill leachate treatment for biological nutrient removal from wastewater. International Journal of Environment and Pollution, 4(1), 97-106. doi: 10.1504/IJEP.1994.028350

Rohrbacher, J., Bilyk, K., Pitt, P., Latimer, R. J., \& Matthews, R. (2011). Successfully Reducing Effluent Total Nitrogen using Conventional Nutrient Removal Strategies. Paper presented at the Striking the Balance between Nutrient Removal in Wastewater Treatment and Sustainability.

Vähätalo, A. V., \& Zepp, R. G. (2005). Photochemical Mineralization of Dissolved Organic Nitrogen to Ammonium in the Baltic Sea. Environmental Science \& Technology, 39(18), 6985-6992. doi: 10.1021/es050142z

Zhao, R., Gupta, A., Novak, J. T., Goldsmith, C. D., \& Driskill, N. (2013). Characterization and treatment of organic constituents in landfill leachates that influence the UV disinfection in the publicly owned treatment works (POTWs). Journal of Hazardous Materials, 258259(0), 1-9. doi: http://dx.doi.org/10.1016/j.jhazmat.2013.04.026 


\section{CHAPTER 6}

\section{FATE OF ORGANIC MATTER FROM LEACHATE DISCHARGED TO WASTEWATER TREATMENT PLANTS}

\section{$\underline{\text { Abstract }}$}

The effects of LOM on wastewater effluent quality was further evaluated in the field. Results showed that leachate detection for each field study could be determined using $\mathrm{UV}_{254 \mathrm{~nm}}$ absorbance. DON and dissolved organic carbon (DOC) concentrations increased at significant levels in leachate-impacted wastewater samples. The DON decreased through the treatment train, suggesting that this parameter was effectively removed, while DOC persisted. DOC pass through coincided with an increase in color and $\mathrm{UV}_{254} \mathrm{~nm}$ absorption. In effluents, the $\mathrm{UV}_{254 \mathrm{~nm}}$ transmittance was just below the minimum $65 \%$ disinfection requirement at dilutions greater than $1 \%$. Leachate-impacted wastewater showed a higher concentration of humic-like peaks during fluorescence measurements than wastewater without leachate.

\section{Introduction}

Leachate generated from a landfill shortly after waste is placed typically has high organic compound concentrations (measured as Chemical Oxygen Demand (COD) from 6-60 g/L; Qasim and Chiang, 1994). As the landfilled waste ages, leachate volume declines from as high as 14,000 L/ha/d to below $900 \mathrm{~L} / \mathrm{ha} / \mathrm{d}$ (Worrell et al., 2002). However, leachate COD remains high (e.g., up to 4.5 g/L) for many decades (Ehrig, 1984; Kjeldsen et al., 2002). Concomitantly, leachate organic matter (LOM) transitions from dominance by aliphatic, low molecular weight compounds to primarily complex and recalcitrant organic compounds (Batarseh et al., 2007; Morris et al., 2003; Robinson et al., 2013). The leachate biochemical oxygen demand (BOD) to 
COD ratio becomes very low as the landfill ages, suggesting LOM recalcitrance (Kjeldsen et al., 2002). Other leachate constituents such as metals tend to decline to low levels in aged leachate, although ammonia is persistent in the anaerobic landfill environment (Kjeldsen et al., 2002).

In situ landfill processes remove readily degradable organic matter in the leachate; however persistent and recalcitrant organic matter may necessitate management of leachate well beyond the closure of the landfill, potentially for hundreds of years (Ehrig and Krümpelbeck, 2001)(Belvi and Baccine, 1989). LOM is problematic because it is highly colored (Matilaninen et al., 2011; He et al., 2006; de Morais et al., 2005), may lead to disinfection byproducts (DBPs) when treated (Kang et al., 2002; Katsumata et al., 2008; Leenheer and Croué, 2003; Matilaninen et al., 2011), and is known to transport heavy metals (Tan et al., 2003; Bolyard et al., 2013a) and hydrophobic organic contaminants (Tan et al., 2003; De Paolis and Kukkonen, 1997).

The primary method of leachate treatment is direct discharge to wastewater treatment plants (WWTPs). Leachate is pretreated at some landfills but only if there are industrial pretreatment requirements. These discharge limits rarely include recalcitrant dissolved organic matter only BOD5. Many studies have reported successful co-treatment of leachate and wastewater at leachate volumetric loadings less than $\sim 10-20 \%$ of influent flow (Cecen and Cakiroglu, 2001; Reinhart et al., 1994). Despite this information, WWTP operators are cautious when accepting leachate, because the variability in characteristics and flows could lead to increased challenges for domestic wastewater treatment (e.g., potential pass through of constituents leading to permit violations, inhibition of biological processes, additional oxygen demand). Dissolved organic nitrogen (DON) and humic-like organic matter is of particular concern; studies have shown that DON is not removed in biological treatment processes and can be a significant fraction of the 
effluent total nitrogen (TN). Because of nutrient loadings to aquatic systems (Citations) and increasingly stringent regulations, effluent TN limits are being lowered. In some cases leachate nitrogen contributes to exceedances in TN permit limits (Reinhart and Bolyard, 2016). A second compound of concern is humic-like organic matter that may interfere with ultraviolet (UV) disinfection. As of 2012, just over 25\% of the WWTPs in the United States used UV disinfection; equating to approximately 4,000 facilities (Faber, 2012; Whitby and Scheible, 2004). UV disinfection is economically attractive as a way to avoid using chemicals as well as a way to avoid the production of disinfection by products. Organic matter may absorb at $254 \mathrm{~nm}$, the wavelength used in these systems. In order to ensure adequate disinfection is achieved, regulations set minimum UV transmittance limits as a function of the upstream filtration processes. If these limits are not met, than the effluent is sent to reject ponds or directly back to the head of the WWTP. Preliminary studies have shown that leachate volumetric contributions as low as 2-5\% of the WWTP influent will interfere with UV disinfection (Zhao et al., 2012).

The specific impacts of leachate on WWTP effluent quality are not well known, particularly at field-scale. The goal of this research was to increase the understanding of the nature and fate of recalcitrant, UV-absorbing, and organic-nitrogen containing compounds in leachate that is cotreated with domestic wastewater. It is expected that organic compound characteristics will depend on their source, whether leachate or domestic wastewater (Korak et al., 2013). This research focused on characterizing both wastewater and leachate to understand the differences in conventional and spectroscopic properties. Based on these data a recognizable leachate molecular fingerprint will allow for the rapid identification of wastewater effluent impacted by leachate organic matte (LOM). Known additions of leachate to wastewater were used to estimate the volumetric contribution using ultraviolet (UV) absorbance at $254 \mathrm{~nm}$ as an indicator 
of the presence of organic matter. Leachate nitrogen contribution to effluent WWTP TN concentration permit exceedances and at what volumetric contribution were evaluated by conducting field sampling at wastewater treatment plants with and without leachate. These data were used to determine the extent to which LOM interferes with UV transmittance in WWTP effluents. This study provided a better understanding of potential implications of accepting leachate for both the landfill and WWTP operators. Additionally, the impediments of disinfection in the presence of LOM were better understood and recommendations were made to ensure that performance complies with permit requirements.

\section{Materials and Methods}

\section{Leachate and Wastewater Characterization and Dilution Study}

Leachate and wastewater were characterized using traditional analysis and advanced spectroscopic tools to explore the structural and biochemical properties of LOM and their behavior at WWTPs. Leachate was collected and characterized to develop baseline data from eight landfills (13 samples) and two WWTPs (effluent and influent; five samples). All collected samples were filtered using a $0.45-\mu \mathrm{m}$ filter prior to chemical analysis. The filtered samples were analyzed for soluble COD (sCOD), $\mathrm{pH}$, ammonia-N, nitrate-N, nitrite-N, total Kjeldahl nitrogen, UV absorbance, DOC, and true color according to Standard Methods (APHA, 2005).

Using these data, the lower bounds on detection of leachate in wastewater could be evaluated. Raw leachate was collected at three landfill sites at a point just prior to discharge into the municipal sewer system. Influent and effluent wastewater samples were also collected from three WWTPs in the absence of leachate. Leachate, as collected, was mixed with wastewater influent and effluent samples at volumetric loadings of $0.01 \%, 0.1 \%, 1.0 \%$, and $10 \%$. These values reflect both published and field data regarding the co-treatment of leachate and 
wastewater (Cecen and Cakiroglu, 2010; Abbas et al., 2009; Reinhart et al., 1994). UV

transmittance was measured for each of these mixtures. Additionally deionized (DI) water was added to wastewater samples at the same aforementioned volumetric loadings to serve as experimental blanks. Detection of leachate was confirmed by detecting a difference between the wastewater UV transmittance and the diluted leachate.

\section{Field Studies of Leachate and Wastewater Co-Treatment}

Field studies were designed to compare WWTP performance in the presence and absence of leachate and the persistence of LOM and other leachate constituents through the WWTP. Two different scenarios were evaluated: Scenario 1, two WWTPs that did not receive leachate during the sampling period (controls) and Scenario 2, two WWTPs receiving leachate (as presented in Table 6-1). Raw leachate was collected at the landfills just prior to the point of discharge into the municipal sewer system. Wastewater was sampled at the WWTP influent and at various points within the treatment train (Figure 6-1). Grab samples were collected every 4 hours over a 24-hour period. Leachate and wastewater were placed in clean high-density polyethylene plastic containers, which were iced during collection as well as transport and stored at $4^{\circ} \mathrm{C}$ until analyzed. 
Table 6-1. Summary of WWTP Sampling Events and Leachate Presence or Absence

\begin{tabular}{|c|c|c|}
\hline Sampling Event & Biological Treatment Processes & Leachate Present or Absent \\
\hline WWTP 1 & Oxidation Ditch & Absent \\
\hline WWTP 2A & Steep-Feed Aeration & Absent \\
\hline WWTP 2B & Steep-Feed Aeration & Present \\
\hline WWTP 2C & Present \\
\hline WWTP 3 & Steep-Feed Aeration & Present $^{\text {b }}$ \\
\hline
\end{tabular}

a. Modified sampling event - targeted influent and effluent sampling at times leachate arrival was expected.

b. Leachate was discharged to WWTP 3 and observed in the influent, however leachate was not captured in the WWTP clarifier or effluent during sampling period as plant retention period was longer than the sampling period.

The total volume and discharge rate of leachate to a WWTP can vary from day to day which can affect the effluent quality. Typically, leachate discharges are reported as the total daily volume and loadings are calculated relative to the total wastewater influent daily volume. These data do not provide sufficient information to elucidate the effects of variable volumetric loadings on the WWTP effluent quality. Total landfill discharges and hourly flow data from the receiving WWTPs were collected during the above-described 24-hour sampling period. UV absorbance at $254 \mathrm{~nm}$ was measured for all influent and effluent samples collected during the field studies. UV absorption was correlated with known additions of leachate to wastewater without leachate, as previously described, to estimate the volumetric contribution at the time of sample collection. These data are critical to making recommendations regarding discharge practices aimed at reducing the impact of leachate on WWTP operations and effluent quality. 


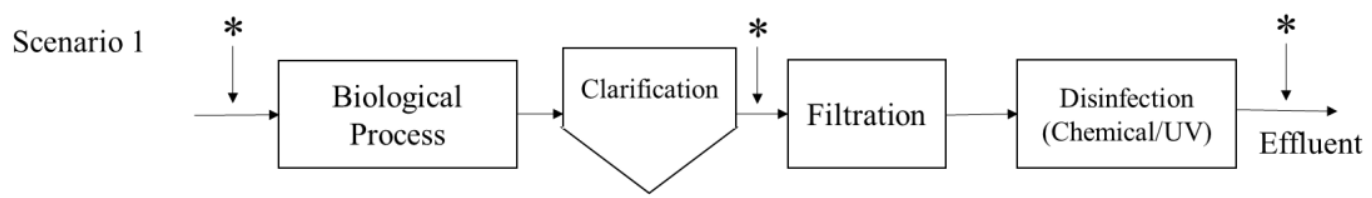

Scenario 2

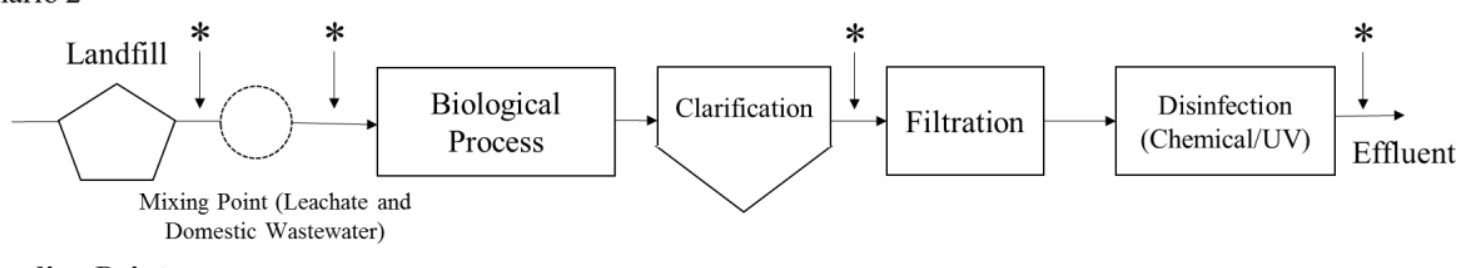

* Sampling Point

Figure 6-1. Treatment and Sampling Scenario

\section{Leachate Fingerprinting in Wastewater Effluent}

Various spectroscopic techniques were used to identify the molecular fingerprint of leachate and wastewater. The specific methods and instruments were selected because there is a growing leachate database of characteristics using these instruments (Bolyard and Reinhart, 2016) and they have rapid throughput. Leachate and wastewater samples were characterized using UV-Vis Spectroscopy (measuring absorbed energy based on the electronic transition in the molecule). Dried leachate samples were characterized using Fourier Transform Infrared spectroscopy (FTIR) to identify vibrational groups. Selected wastewater samples were characterized using fluorescence.

UV-Vis Spectroscopy was used to measure the absorbed energy based on the electronic transition in the molecules. Leachate and wastewater samples were placed in a 1.0-cm cell and the absorbance was measured at $254 \mathrm{~nm}, 465 \mathrm{~nm}$, and $665 \mathrm{~nm}$ using a HACH DR-5000 UV-Vis Spectrophotometer. Samples with readings exceeding 3.5 absorbance units were diluted to less than 2.0 abs. 
Leachate was dried at $105^{\circ} \mathrm{C}$ and analyzed using a Perkin Elmer Spectrum 100 Series FTIR. A background scan was taken before each analysis to remove any contribution of air from the spectrum. A spectrum was acquired by placing a small amount of the sample on a diamond ATR device (attenuated total reflectance) then applying the pressure arm until the force gauge reads approximately 80 . Three spectra were acquired for all samples. Transmittance peaks were labeled and identified based on published assignments for FTIR spectral peaks. FTIR data were further analyzed using Principal Component Analysis (PCA) to understand the variance in the data. Overall this method was used to identify patterns in the data sets and highlight differences and similarities (Smidt and Schwanninger, 2007; Smidt et al., 2002).

Wastewater fluorescence was measured using a NanoLog Fluorescence spectrometer (HORIBA Scientific) with a 1-cm path-length quartz cuvette. Each liquid sample was diluted to the same absorbance at $254 \mathrm{~nm}$ to remove any concentration-dependent effects on the fluorescence measurements. Spectra were measured at the four primary excitation peaks/emission peaks: Peak A (Ex/Em $=260 / 380-460 \mathrm{~nm}$; humic-like), Peak C $(E x / E m=$ 350/420-480 nm; humic-like), Peak M (Em/Ex = 312/380-420 nm; marine-like) and Peak T (Em/Ex 275/340 nm, tryptophan/ tyrosine-protein-like material). The fluorescence values of each peak were used to identify differences in spectral characteristics of OM. 


\section{$\underline{\text { Results and Discussion }}$}

\section{Leachate and Wastewater Characterization}

The following samples were collected and characterized to develop baseline data: (1) leachate from eight landfills (total thirteen samples, Table 6-2) and (2) WWTP samples in the absence of leachate (five locations, Table 3). A complete set of data for leachate can be found in the Appendix E (Table E-1).

Table 6-2. Comparison of Leachate (13 Samples) and Influent Wastewater (5 Samples)

\begin{tabular}{|c|c|c|c|c|c|c|c|}
\hline \multirow[b]{2}{*}{ Parameter } & \multicolumn{4}{|c|}{ Leachate } & \multicolumn{3}{|c|}{ Wastewater Influent } \\
\hline & Min & $\operatorname{Max}$ & $\begin{array}{c}\text { Average } \\
\quad(13 \\
\text { samples })\end{array}$ & $\begin{array}{l}\text { Std. } \\
\text { Dev. }\end{array}$ & $\begin{array}{l}\text { WWTP } 1 \\
\text { Sample A }\end{array}$ & $\begin{array}{l}\text { WWTP } 1 \\
\text { Sample B }\end{array}$ & WWTP 3 \\
\hline Total $\mathrm{cBOD}_{5}$ & 68 & 3730 & 651 & 981 & NA & 143 & 157 \\
\hline Total COD (mg/L) & 775 & 12300 & 4026 & 3080 & 165 & 224 & 482 \\
\hline $\mathrm{cBOD}_{5} / \mathrm{COD}$ & 0.02 & 0.30 & 0.12 & 0.081 & NA & 0.64 & 0.33 \\
\hline $\mathrm{pH}$ (S.U.) & 7.07 & 8.54 & 7.81 & 0.390 & 6.8 & 6.92 & 7.28 \\
\hline Total $\mathrm{NH}_{3}-\mathrm{N}(\mathrm{mg} / \mathrm{L})$ & 98 & 2300 & 1020 & 693 & 33 & 32 & 45.6 \\
\hline $\begin{array}{c}\text { Total } \mathrm{NO}_{3}-\mathrm{NO}_{2} \\
(\mathrm{mg} / \mathrm{L})\end{array}$ & 7.0 & 66 & 32.6 & 19.6 & 0.832 & 0.91 & 0.77 \\
\hline Total TKN (mg/L) & 210 & 2360 & 1130 & 680 & 40.8 & 41.4 & 53.2 \\
\hline $\begin{array}{l}\text { Total Nitrogen } \\
(\mathrm{mg} / \mathrm{L})\end{array}$ & 216 & 2440 & 1160 & 698 & 41.6 & 42.3 & 54 \\
\hline DON (mg/L) & 10 & 97 & 40.7 & 27.4 & 3.47 & 2.45 & 5.9 \\
\hline DOC $(\mathrm{mg} / \mathrm{L})$ & 239 & 4420 & 1340 & 1090 & 8.9 & 8 & 29 \\
\hline DOC/DON & 14.7 & 88.4 & 38 & 22.2 & 2.6 & 3.3 & 4.9 \\
\hline SUVA (L/mg-m) & 2.43 & 4.55 & 3.59 & 0.66 & 3.34 & 3.7 & 1.86 \\
\hline Dissolved UV-254 & 7.54 & 190 & 52.5 & 48.7 & 0.297 & 6.5 & 0.54 \\
\hline $\mathrm{E}_{4} / \mathrm{E}_{6}$ (unitless) & 3.00 & 8.20 & 5.77 & 1.57 & 4.3 & 6.5 & 2.1 \\
\hline Total UV-245 & 6.50 & 191 & 54.7 & 49.2 & 0.964 & 0.584 & 0.974 \\
\hline
\end{tabular}

NA: not analyzed 
Table 6-3. WWTP Effluent Sample Analysis

\begin{tabular}{|c|c|c|}
\hline Sample & WWTP 1 & WWTP 3 \\
\hline Total $\mathrm{cBOD}_{5}$ & 3.4 & 5 \\
\hline Total COD $(\mathrm{mg} / \mathrm{L})$ & 19 & 25 \\
\hline $\mathrm{cBOD}_{5} / \mathrm{COD}$ & 0.18 & 0.19 \\
\hline pH (S.U.) & 7.33 & 7.57 \\
\hline Total $\mathrm{NH}_{3}-\mathrm{N}(\mathrm{mg} / \mathrm{L})$ & 0.446 & 0.02 \\
\hline $\begin{array}{c}\text { Total } \mathrm{NO}_{3}-\mathrm{NO}_{2} \\
(\mathrm{mg} / \mathrm{L})\end{array}$ & 1.37 & 0.27 \\
\hline Total TKN (mg/L) & 1.53 & 0.82 \\
\hline Total Nitrogen $(\mathrm{mg} / \mathrm{L})$ & 2.9 & 1.09 \\
\hline $\mathrm{DON}(\mathrm{mg} / \mathrm{L})$ & 0.65 & 0.80 \\
\hline DOC $(\mathrm{mg} / \mathrm{L})$ & 6.75 & 6.21 \\
\hline DOC/DON & 10.3 & 7.6 \\
\hline SUVA (L/mg-m) & 2.48 & 1.75 \\
\hline Dissolved $\mathrm{UV}_{254}$ & 0.17 & 0.11 \\
\hline $\mathrm{E}_{4} / \mathrm{E}_{6}$ (unitless) & 8 & ND \\
\hline Total $\mathrm{UV}_{245}$ & 0.181 & 0.109 \\
\hline
\end{tabular}

Thirteen leachate samples collected from eight landfills yielded a wide variation of values for the leachate parameters outlined in Table 6-2 and E-1. Some of the observed differences can be attributed to landfill operation (e.g., conventional liner system vs. slurry wall, age of the landfill, waste characteristics). Leachate overall had a low biodegradability $\left(\mathrm{cBOD}_{5} / \mathrm{COD}>0.3\right)$ relative to wastewater influent $(>0.30)$. Wastewater effluent biodegradability as measured by $\mathrm{cBOD}_{5} / \mathrm{COD}$, decreased to less than 0.19 after treatment (Table 6-3). Higher COD, TN, DOC, DON, $\mathrm{UV}_{254}$ absorbance, and $\mathrm{pH}$ were measured in leachate relative to wastewater effluent. Specific UV absorbance (SUVA) is related to the absorbance of a sample at $\mathrm{UV}_{254} \mathrm{~nm}$ divided by the DOC concentration. SUVA is typically higher in leachate than in wastewater (Chin et al., 1994). In this study, SUVA was similar for wastewater and leachate as DOC and UV absorbance at $254 \mathrm{~nm}$ were proportionally lower in wastewater. Samples collected from WWTP 1 may be 
affected by the presence of anaerobic digester supernatant. Prior to anaerobic digestion, solids were dewatered though a gravity belt thickener.

The spectral characteristics of the collected leachate samples were determined using FTIR. Figure F-1 summarizes the spectra of all thirteen samples. Aromatic, organic, inorganic, and nitrogen functional groups were identified in most of the samples. Table 6-4 summarizes the identified functional groups, based on wavenumbers, and the leachates containing those groups. Aromatic functional groups were present in samples collected from closed landfill cells and have been shown to reflect a well-stabilized leachate based on our previous work (Reinhart and Bolyard, 2013). Aliphatic methylene groups were also present in the same samples and represent organic matter linked in straight/branched chains suggesting a complex organic matter such as humic substances. The SUVA values of these three samples were above 2.0, which also signifies the dominance of humic substances. Nitrate groups were present in all samples. Leachate $\mathrm{L}$ transmittance at $1397 \mathrm{~cm}^{-1}$ was $69 \%$ and was the most significant peak at this wavelength. This sample also had the highest concentration of $\mathrm{NO}_{3}$, which correlates well with the FTIR data. The remaining functional groups that were identified were inorganic (e.g., carboxylic/carbonate). As a landfill stabilizes the FTIR spectrum of leachates shifts from organic to inorganic (Schmidt et al., 2011; Reinhart and Bolyard, 2013). 
Table 6-4. Summary of Detected Leachate Functional Groups that Dominated FTIR Spectra

\begin{tabular}{|c|c|c|}
\hline $\begin{array}{c}\text { Wavenumber } \\
\left(\mathbf{c m}^{-1}\right)\end{array}$ & Chemical Functional Group & Leachates \\
\hline $2981 \mathrm{~cm}^{-1}$ & Aromatic & $\mathrm{A}, \mathrm{B}, \mathrm{C}$ \\
\hline $\begin{array}{l}2920 \mathrm{~cm}^{-1} \text { and } 2850 \\
\mathrm{~cm}^{-1}\end{array}$ & Aliphatic methylene & $\mathrm{A}, \mathrm{B}, \mathrm{C}$ \\
\hline $1556 \mathrm{~cm}^{-1}$ & Amides II & $\begin{array}{l}\mathrm{A}, \mathrm{B}, \mathrm{C}, \mathrm{F}, \mathrm{G}, \mathrm{H}, \mathrm{I}, \\
\text { and } \mathrm{L}\end{array}$ \\
\hline $1397 \mathrm{~cm}^{-1}$ & Nitrate & All \\
\hline $\begin{array}{l}1054 \mathrm{~cm}^{-1}, 1033 \mathrm{~cm}^{-1} \\
\text { and } 1012 \mathrm{~cm}^{-1}\end{array}$ & Inorganics & $\begin{array}{c}\mathrm{A}, \mathrm{C}, \mathrm{H}, \mathrm{K}, \mathrm{M}, \text { and } \\
\mathrm{N}\end{array}$ \\
\hline $1033 \mathrm{~cm}^{-1}$ & Inorganics & $\mathrm{G}$ \\
\hline $1022 \mathrm{~cm}^{-1}$ & Inorganics (Silicate) & Leachate(s) \\
\hline $879 \mathrm{~cm}^{-1}$ & $\begin{array}{c}\text { Carboxylic; Carbonate (COO-) (monovalent } \\
\text { anion site) }\end{array}$ & $\mathrm{G}, \mathrm{I}, \mathrm{K}, \mathrm{M}$, and $\mathrm{N}$ \\
\hline $871 \mathrm{~cm}^{-1}$ & $\begin{array}{c}\text { Carboxylic; Carbonate (COO-) (divalent anion } \\
\text { site) }\end{array}$ & $\mathrm{H}$ and $\mathrm{J}$ \\
\hline
\end{tabular}

Principal Component Analysis (PCA) was used to evaluate the variance in the acquired data. PCA is specifically useful to identify patterns in FTIR data sets and highlight differences and similarities (Smidt and Schwanninger, 2007; Smidt et al., 2002). Figure 6-2 shows variation among the leachate samples. The positive and negative principal components (PCs) and associated functional groups based on PCA loading plots are summarized in Table 6-5.

Leachates A, B, C, and E were influenced by negative PC 1 (84\% variance) and positive PC 2 (6\% variance) which represent amide $\left(1559 \mathrm{~cm}^{-1}\right)$, nitrate $\left(1397 \mathrm{~cm}^{-1}\right)$, and carboxylic/carbonate (COO-) (divalent anion site, $871 \mathrm{~cm}^{-1}$ ) groups. The remaining leachates $(\mathrm{G}, \mathrm{H}, \mathrm{I}, \mathrm{J}, \mathrm{K}, \mathrm{M}$, and $\mathrm{N}$ ) were influenced by negative PCs 1 and 2 . The differences are mainly attributed to the dominance of inorganic functional groups relative to Leachates A, B, C, and E. Leachates A, B, and E were collected from the same landfill and would explain the similar characteristics picked up through FTIR. 


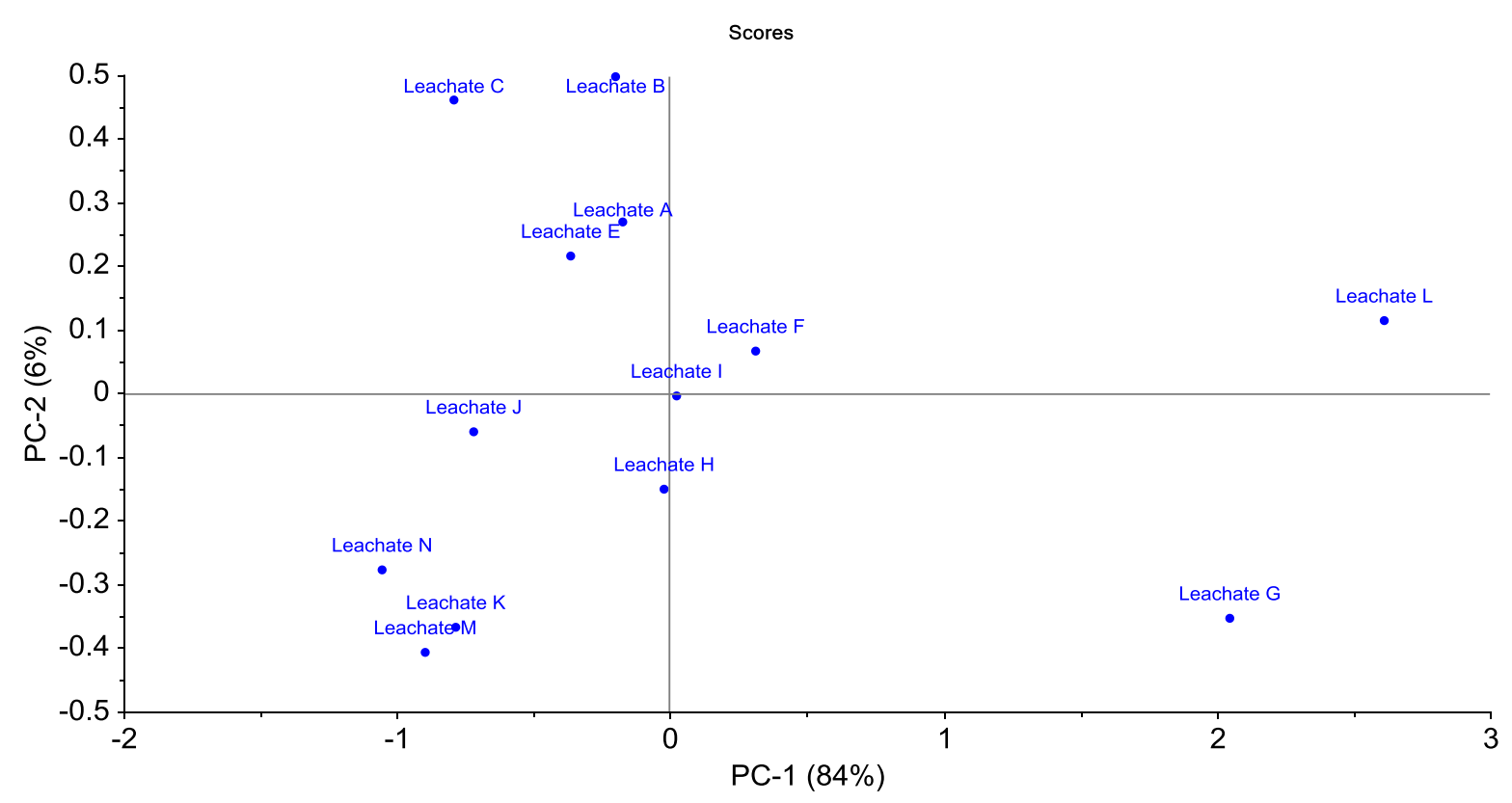

Figure 6-2. PCA Scores Plot of FTIR Spectrum of Leachate Samples

Table 6-5. Principal Component Scores Related to Loading Plots*

\begin{tabular}{|c|c|c|}
\hline PC (+/-) & Wavenumbers $\left(\mathrm{cm}^{-1}\right)$ & Leachates \\
\hline PC 1 (-) & $1556 \mathrm{~cm}^{-1}$ and $1397 \mathrm{~cm}^{-1}$ & $\begin{array}{c}\text { A, B, C, E, G, H, J, K, } \\
\text { M, and N }\end{array}$ \\
\hline PC 2 (+) & $1397 \mathrm{~cm}^{-1}$ and $871 \mathrm{~cm}^{-1}$ & A, B, C, E, F, and L \\
\hline PC 2 (-) & $1556 \mathrm{~cm}^{-1}, 1054 \mathrm{~cm}^{-1}, 1033 \mathrm{~cm}^{-1}$, and $1012 \mathrm{~cm}^{-1}$ & G, H, I, J, K, M, and N \\
\hline PC 3 (+) & $1556 \mathrm{~cm}^{-1}$ & A, B, C, E, G, H, J, and \\
PC 3 (-) & $1054 \mathrm{~cm}^{-1}, 1033 \mathrm{~cm}^{-1}, 1012 \mathrm{~cm}^{-1}$, and $871 \mathrm{~cm}^{-1}$ & F, L, M, and N \\
\hline
\end{tabular}

*Loading plots can be found in Appendix (Figures E-2 and E-3)

Determination of Leachate Volumetric Contribution using UV-Vis Spectroscopy

Leachate detection limits in wastewater influent and effluent were determined by dilution studies using samples collected from Leachate A and WWTP 1, Leachate F and WWTP 2, and Leachate $\mathrm{H}$ and WWTP 3. By comparing the UV-Vis transmittance of leachate diluted with 
wastewater influent to wastewater alone, leachate could be detected in wastewater at values equal to or below $0.01 \%$ by volume for all three facilities (Figure 6-3). Leachate could potentially be detected at less than $0.01 \%$ for WWTPs 2 and 3 as their UV transmittances were below wastewater without leachate. At $0.01 \%$ by volume, the UV transmittances of leachate diluted by wastewater effluent were $\sim 25 \%-36 \%$ lower than wastewater diluted by DI water or leachate diluted by DI water (Figures E-5 and E-6). This dilution study also brought to light that even at a leachate to wastewater volumetric contribution of $0.01 \%$ for Leachate A/WWTP 1 , the UV transmittance was just below the minimum $65 \%$ necessary to meet the disinfection requirement of less than 200 fecal coliform values per $100 \mathrm{~mL}$ for reuse (F.A.C 62-600.440; National Water Research Institute, 2012) (Figure 6-4). Combinations of Leachate F/WWTP 2 and Leachate H/WWTP 3 were able to meet the $65 \%$ requirement at a volumetric contributions of $0.1 \%$ and lower which is attributed to the low $\mathrm{UV}_{254} \mathrm{~nm}$ leachate absorbance (Table E-1).

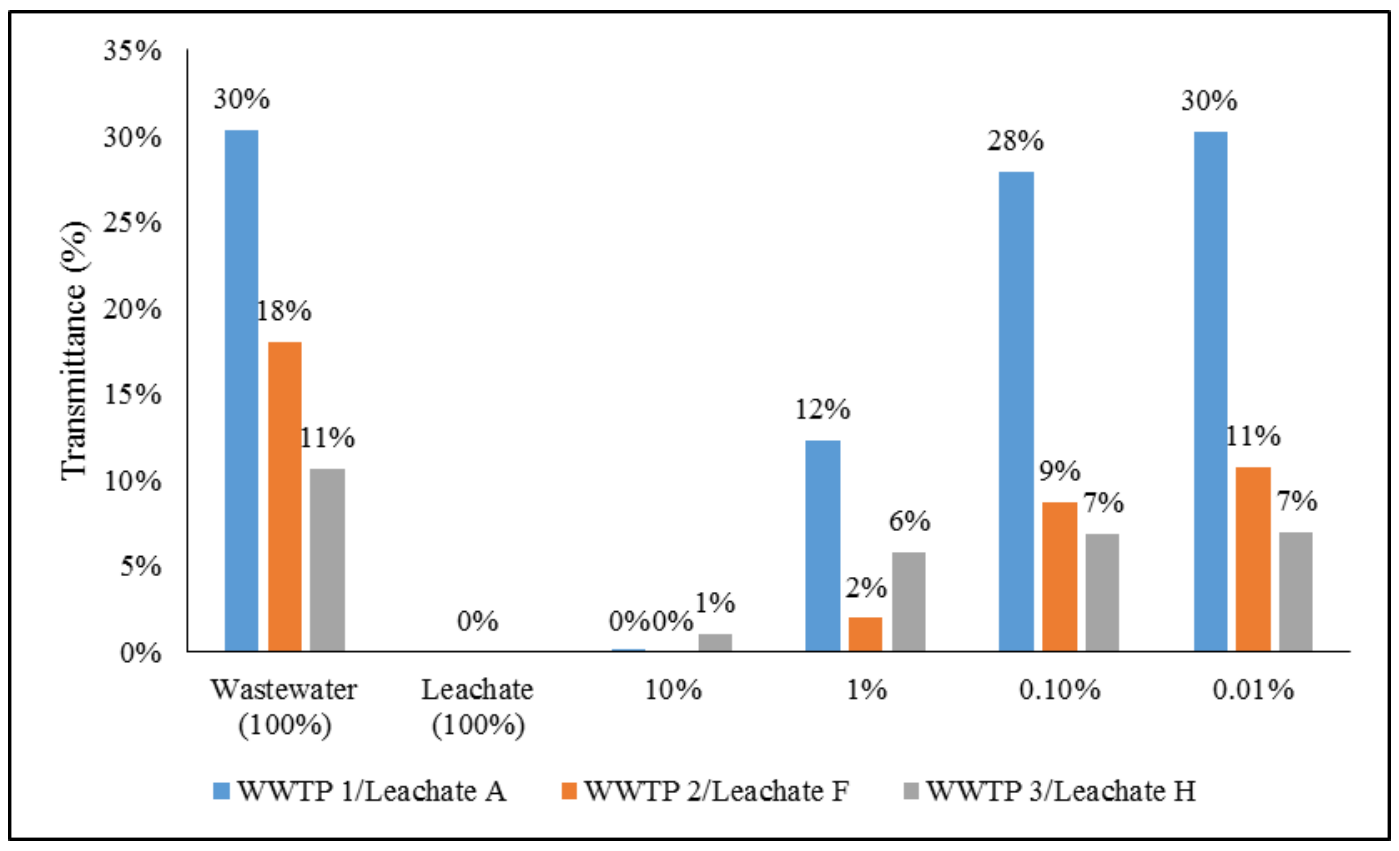

Figure 6-3. UV 254 Transmittance of Leachate And Wastewater Influent Dilution Tests 


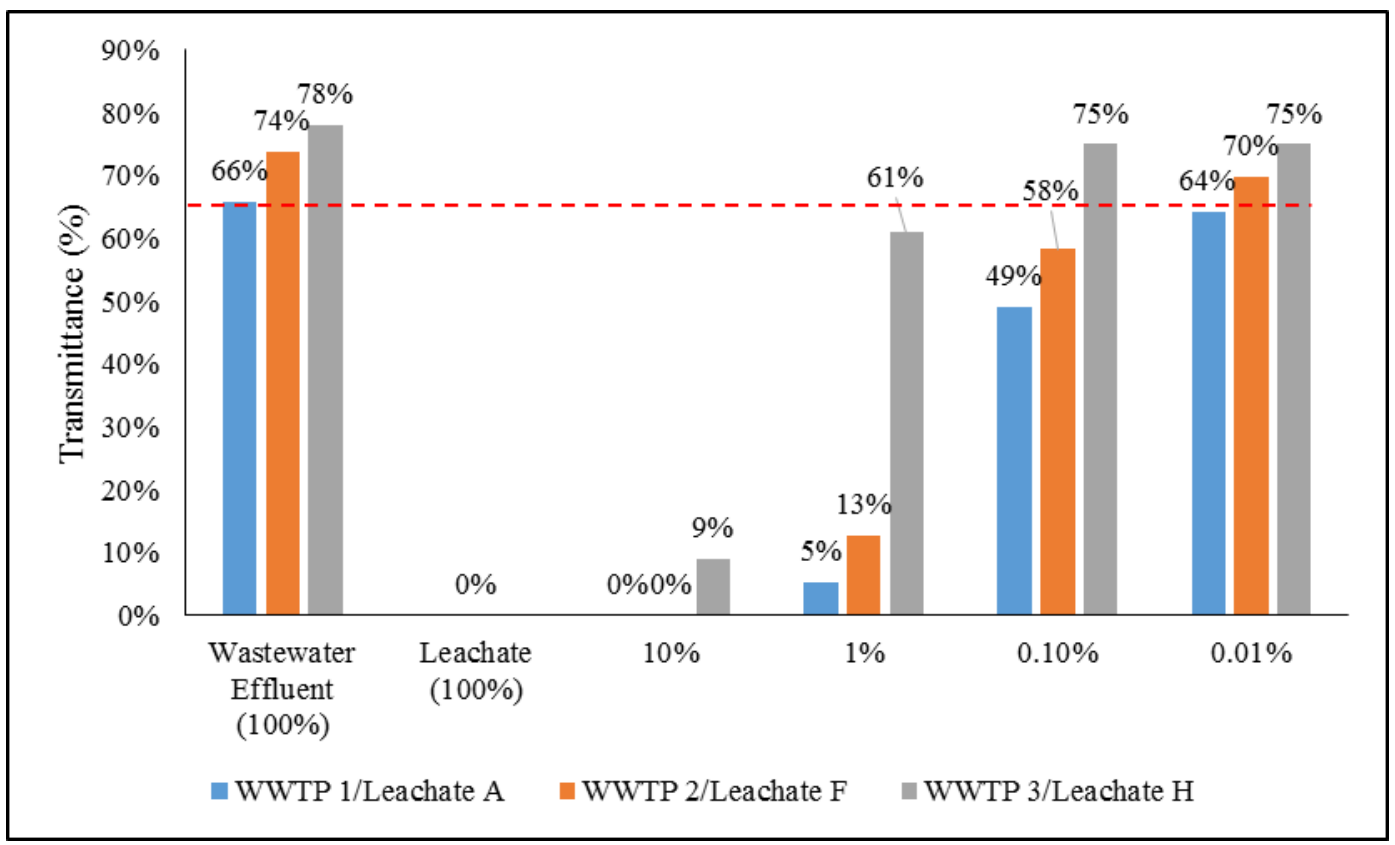

Figure 6-4. UV 254 Transmittance of Leachate and Wastewater Effluent Dilution Tests

\section{Field Studies of Leachate and Wastewater Co-Treatment}

The field study of leachate co-treatment with wastewater involved five sampling events at three WWTPs (see Table 6-2). Grab samples were collected every 4 hours over a 24-hour period at the influent composite samples, and after clarification and disinfection. Results from WWTP 2 were used to evaluate the fate of leachate throughout the WWTP. Results from WWTP 1 and 2A, without leachate, showed the relative flatness of DON, sCOD, and DOC concentrations (Figures E-9 and E-10). The data for WWTP 2A (without leachate) were used to normalize leachateimpacted samples by non-impacted samples.

Leachate detection for each field study was tested using $\mathrm{UV}_{254}$ absorbance measurements, which were used to determine flow data from each landfill. Each sample with a significant increase in absorbance, relative to samples without leachate, was identified as a leachate 
detection and subsequent impacts were further evaluated. Table 6-6 identified samples where leachate was detected. Leachate was detected in influent, clarifier, and effluent samples for WWTP 2B. Figure 6-5 illustrates the increase in $\mathrm{UV}_{254}$ absorbance when leachate arrived compared to WWTP 2A without leachate. Leachate was detected in WWTP 2C and 3 influent between 12:00 am-4:00 am and 8:00 pm, respectively, but the sampling plan did not capture the leachate leaving the plant because the HRT exceeded the sampling duration. WWTP 3 will be resampled to capture leachate in the clarifier and after disinfection. Figure E-11 shows the wastewater influent UV absorbance for WWTP 3. The UV 254 absorbance of influent and effluent samples were also observed to be relatively constant when leachate was not discharged to the WWTP 2A and WWTP 1. 
Table 6-6. Leachate Detection Based on Increase in UV 254 Absorbance

\begin{tabular}{|c|c|c|c|}
\hline Leachate Detection & Influent & Clarifier & Effluent \\
\hline WWTP 2B & 4:00 pm-12:00 am & 12:00 am-4:00 am & $12: 00 \mathrm{am}-4: 00 \mathrm{am}$ \\
\hline WWTP 2C & $12: 00 \mathrm{am}-4: 00 \mathrm{am}$ & No Data & Not Detected \\
\hline WWTP 3 & $8: 00$ PM & Not Detected & Not Detected \\
\hline
\end{tabular}

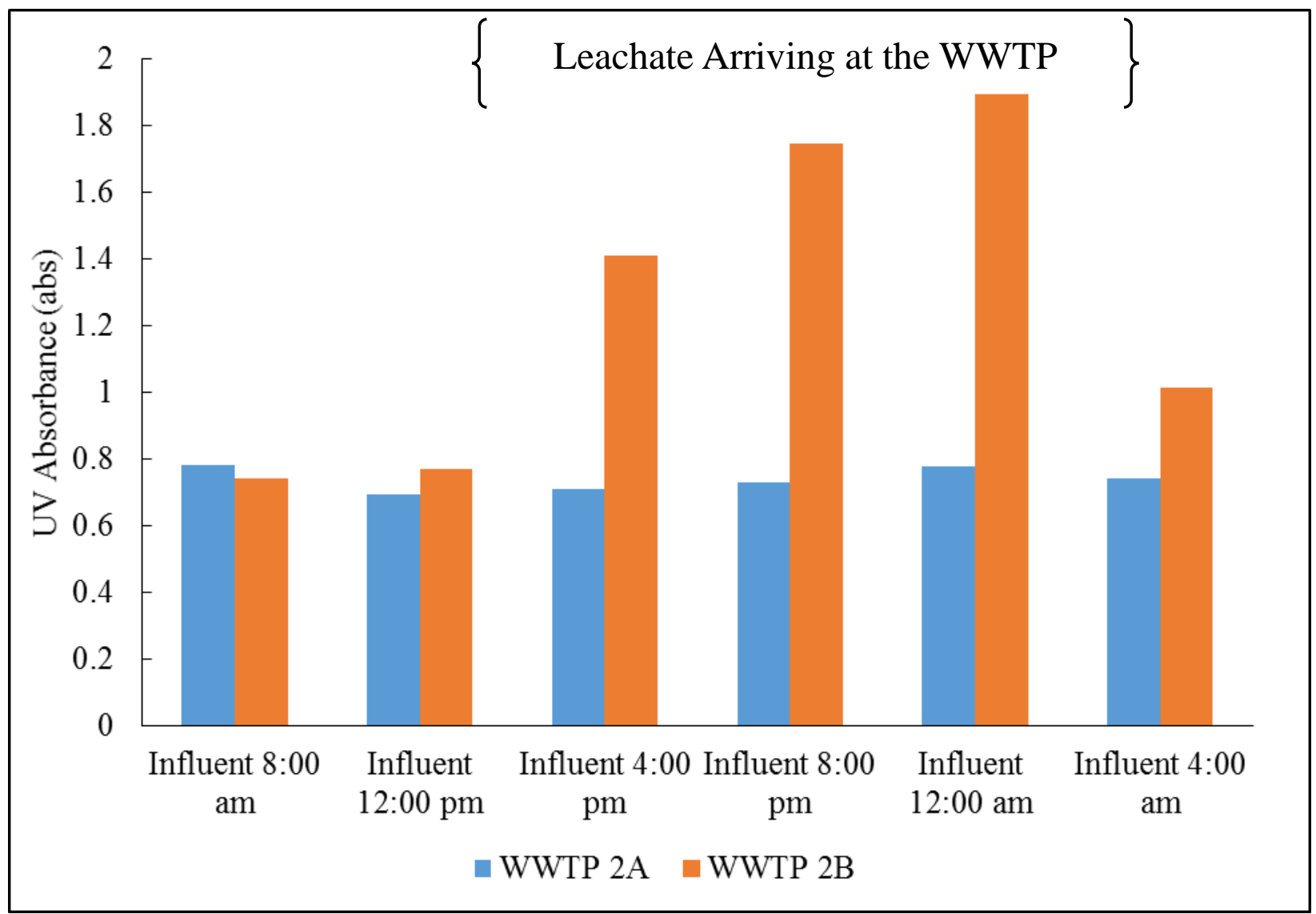

Figure 6-5. UV 254 Absorbance of WWTP 2A and 2B Influent

Effluent impacts detected based on $\mathrm{UV}_{254}$ absorbance were also confirmed through visual observation and apparent color measurements (absorbance at $456 \mathrm{~nm}$ ). Figure 6-6 shows effluent bottles organized by sampling time; two samples appeared to be impacted by leachate (i.e., 12:00 am and 4:00 am). This persistence of color suggests that the leachate organic matter was resistant to biological degradation at this facility. This color change also affected the measured $\mathrm{UV}_{254}$ 
transmittance causing this facility to fall below the required $65 \%$ transmittance for disinfection (Figure 6-7; note this facility does not utilize UV disinfection).

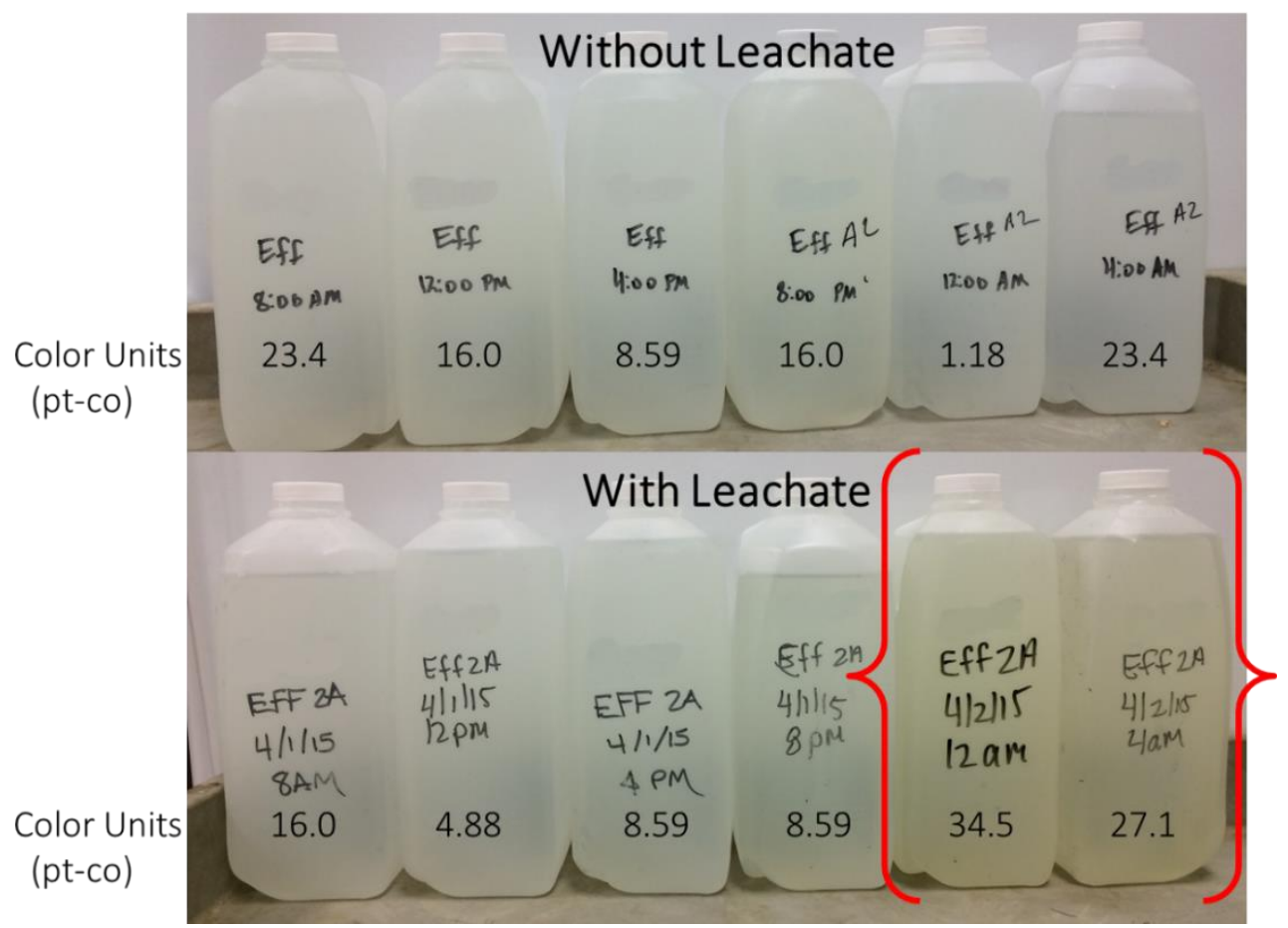

Figure 6-6. WWTP Effluent (WWTP 2A) with and without Leachate (WWTP 2B) 


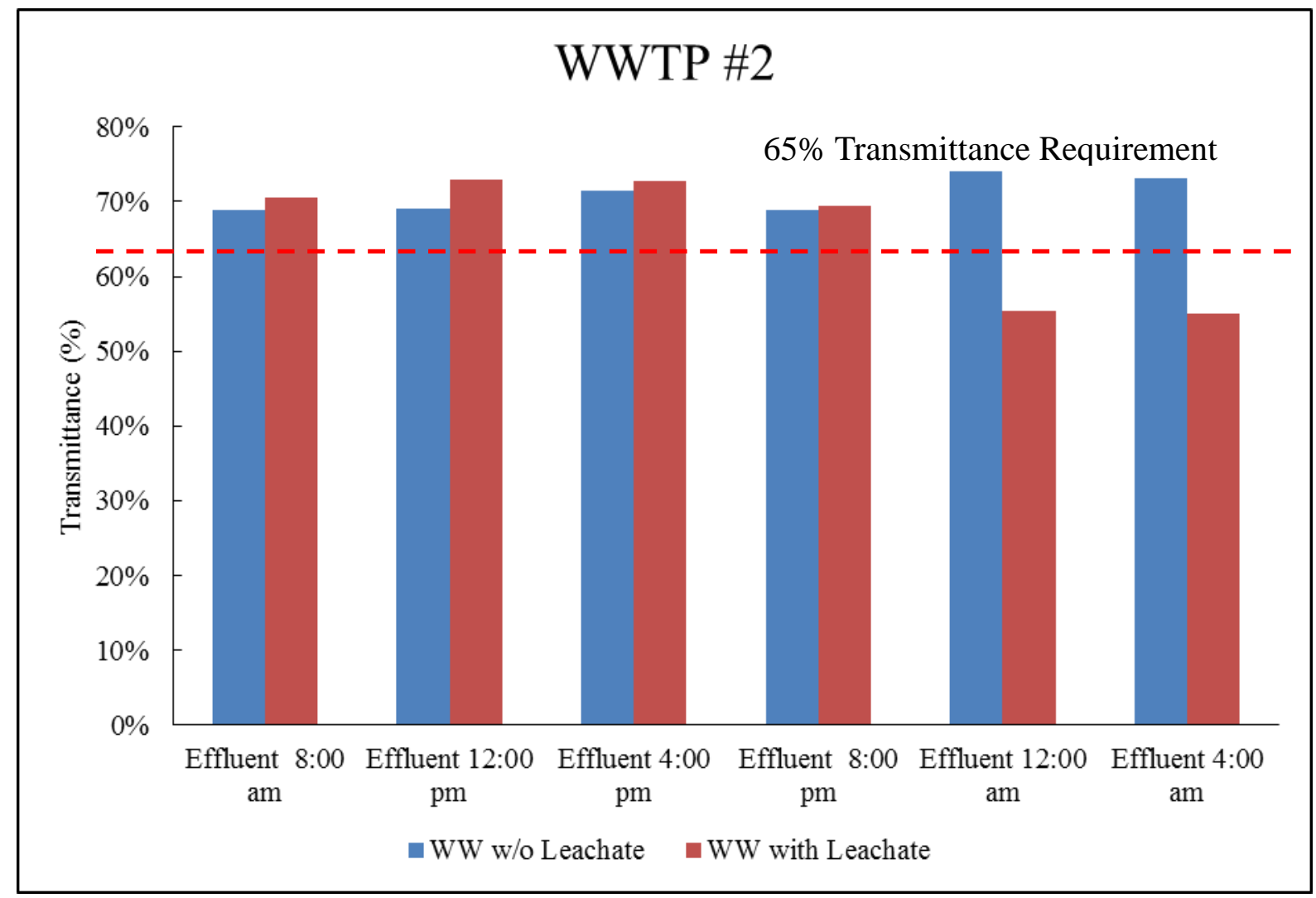

Figure 6-7. $\mathrm{UV}_{254}$ Percent Transmittance of Wastewater Effluent with and without Leachate at WWTP 2

Studies on the co-treatment of leachate and wastewater report the total leachate volumetric loading rate relative to the total wastewater influent daily flow and leachate discharges and do not necessarily represent the loading at the time of sampling. The landfills studied do not record hourly leachate flows to each WWTPs therefore a method to estimate this information was needed. The UV absorbance at $254 \mathrm{~nm}$ was measured for all WWTPs influent samples evaluated in this study as a baseline (i.e., leachate volumetric contribution of $0 \%$ ). Known additions of leachate to the WWTP influent were prepared and a calibration curve was developed to estimate the volumetric contribution of the field samples. UV absorbance at $254 \mathrm{~nm}$ was measured on all influent samples collected in the field studies and the volumetric contribution was calculated 
based on their respective calibration curves (Figures E-7 and E-8). The leachate volumetric contributions for WWTPs 2B and 2C and WWTP 3 are summarized in Table 6-9.

Table 6-7. Estimated Volumetric contribution Using Known Addition of Leachate Added to Wastewater Influent (without Leachate)

\begin{tabular}{|c|c|c|c|}
\hline \multirow{2}{*}{ Sampling Time } & WWTP 2B & WWTP 2C & WWTP 3 \\
\cline { 2 - 4 } & \multicolumn{3}{|c|}{ Volumetric contribution (\%) } \\
\hline $8: 00 \mathrm{am}$ & 0.0 & NS & 0.0 \\
\hline 12:00 pm $\left(2: 00 \mathrm{pm}^{\mathrm{a}}\right)$ & 0.0 & 0.026 & 0.18 \\
\hline $4: 00 \mathrm{pm}$ & 0.59 & $\mathrm{NS}$ & 0.93 \\
\hline $8: 00 \mathrm{pm}\left(7: 00 \mathrm{pm}^{\mathrm{a}}\right)$ & 1.1 & 0.16 & 7.9 \\
\hline $12: 00 \mathrm{am}$ & 1.3 & 0.84 & 1.1 \\
\hline $2: 00 \mathrm{am}$ & $\mathrm{NS}^{\mathrm{c}}$ & 2.2 & $\mathrm{NS}$ \\
\hline 4:00 am $(5: 00 \mathrm{am})$ & 0.052 & $\mathrm{NS}$ & 0.00 \\
\hline
\end{tabular}
a. WWTP 2C
b. WWTP 3
c. No sample

The impacts of leachate on DON, sCOD, and DOC concentration for WWTP 2B were evaluated by normalizing measured concentrations in wo ways (1) using WWTP 2A data (without leachate; Table 6-8) and (2) using non-impacted samples, collected during the same sampling period, from WWTP 2B (Table 6-9). When comparing the sampling event without leachate (WWTP 2A) and with leachate (WWTP 2B), DOC was slightly impacted (i.e., normalized values were above 1), but DON was not impacted by leachate (i.e., normalized values were below 1) (Table 6-10). On the other hand, when comparing the leachate-impacted samples for WWTP 2B to non-impacted samples during the same sampling event these parameters were significantly impacted (normalized values were greater than 1). These observations may be attributed to variations in wastewater characteristics from one day to another (i.e., a higher nitrogen loading was captured while sampling at WWTP 2A). DON ratio 
decreased through the plant suggesting that this parameter was effectively removed in the plant, while DOC persisted. DOC pass-through coincided with an increase in color and UV absorption. Table 6-8. WWTP 2B Leachate Impacted Samples Normalized by WWTP 2A*

\begin{tabular}{|c|c|c|c|}
\hline & Influent & Clarifier & Effluent \\
\hline DON & 0.90 & 0.92 & 0.90 \\
\hline sCOD & 0.90 & 1.13 & 1.01 \\
\hline DOC & 1.14 & 1.09 & 1.32 \\
\hline
\end{tabular}

* Same WWTPs

Table 6-9. WWTP 2B Leachate Impacted Samples* Normalized by Non-Impacted Samples for WWTP2B

\begin{tabular}{|c|c|c|c|}
\hline & Influent & Clarifier & Effluent \\
\hline DON & 1.23 & 2.08 & 0.89 \\
\hline sCOD & 0.86 & 1.17 & 0.99 \\
\hline DOC & 1.52 & 1.33 & 1.95 \\
\hline
\end{tabular}

*See Table 9

Figure 6-13 show that there was minimal reduction in DOC concentrations after biological treatment ( $\sim 6$ hour HRT) and clarification ( 4-5 hour HRT) which would be expected as the organic matter found in the DOC fraction would not settle out. DOC and SCOD captures organic matter that can be responsible for the colored effluent samples which is most likely recalcitrant and will pass through the WWTP. 

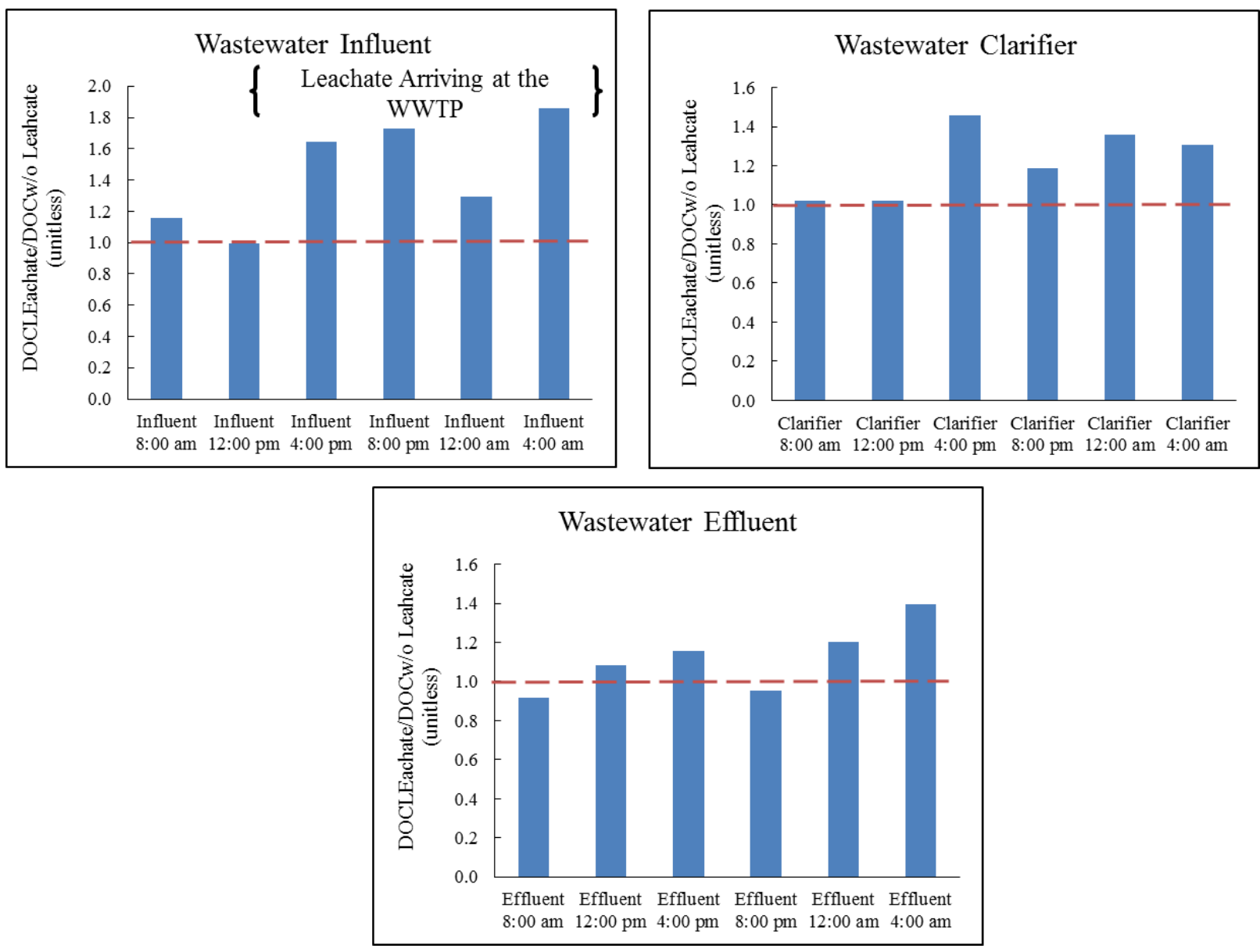

Figure 6-8. DOC in Wastewater with Leachate (WWTP 2B) Normalized by Wastewater without Leachate (WWTP 2A)

\section{Leachate Organic Matter Fingerprinting}

Detecting the changes in wastewater characteristics specifically from leachate impacts required the following information: (1) wastewater baseline without leachate and (2) data on color $\left(\mathrm{UV}_{456 \mathrm{~nm}}\right), \mathrm{DOC}, \mathrm{UV}_{254 \mathrm{~nm}}$, and fluorescence (i.e., characterization of the organics present). These parameters were selected specifically because of their sensitivity to leachate arriving at a WWTP. For example, UV-Vis absorbance for WWTP 2A had minimal variations in absorbance across the measured range $(200 \mathrm{~nm}-800 \mathrm{~nm})$, over time without leachate (Figure 6-9). A similar trend was observed for WWTP 3 (Figure 6-10). When leachate arrived at WWTP 2 during a 
second sampling event (WWTP 2B) the spectra shifted due to the increase in $\mathrm{UV}_{254} \mathrm{~nm}$ absorbance. However the presence of leachate in WWTP 2B effluent was detected by a minor shift in the spectra as can be observed in Figure 6-9.
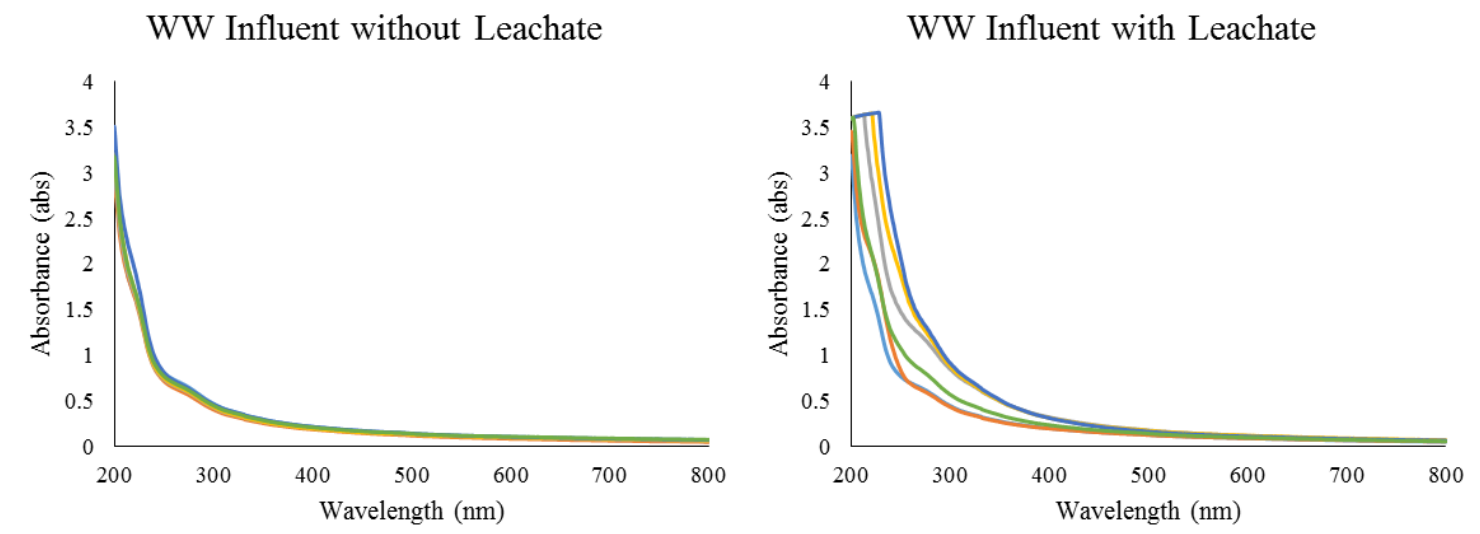

WW Effluent without Leachate
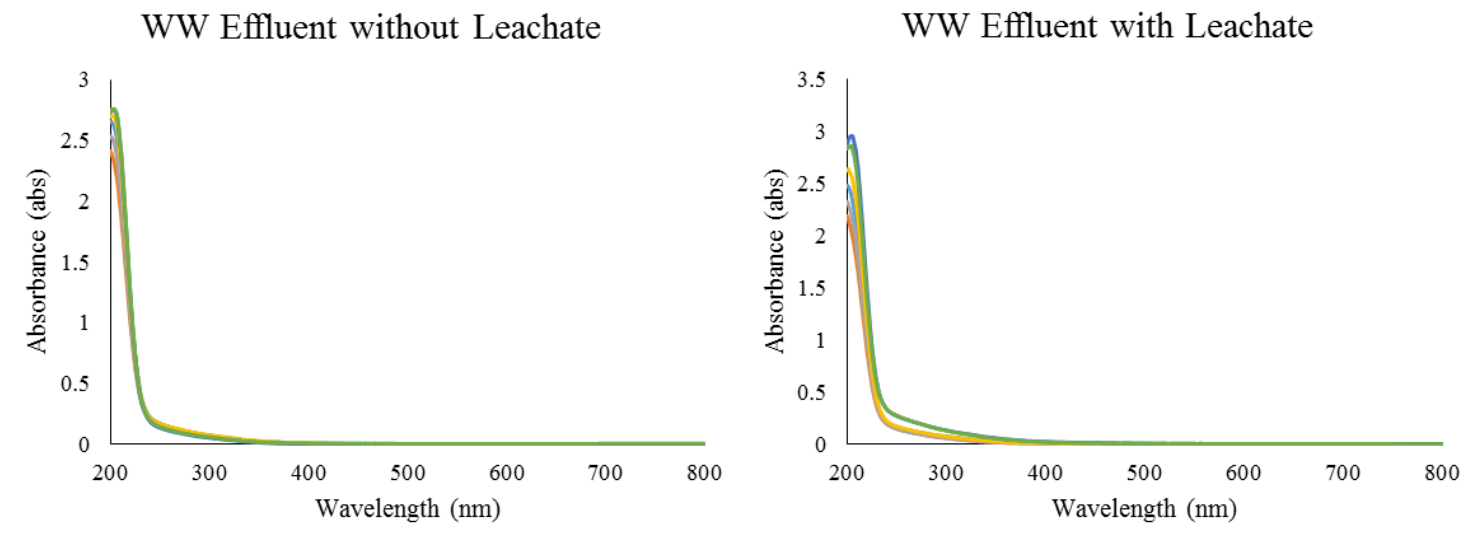

Influent 8:00 am NF - Influent 12:00 pm NF - Influent 4:00 pm NF
Influent 8:00 pm NF - Influent 12:00 am NF —- Influent 4:00 am NF

Figure 6-9. UV-Vis Scan (200 nm to $800 \mathrm{~nm}$ ) of Wastewater Influent and Effluent Samples with and without Leachate (WWTP 2C) 


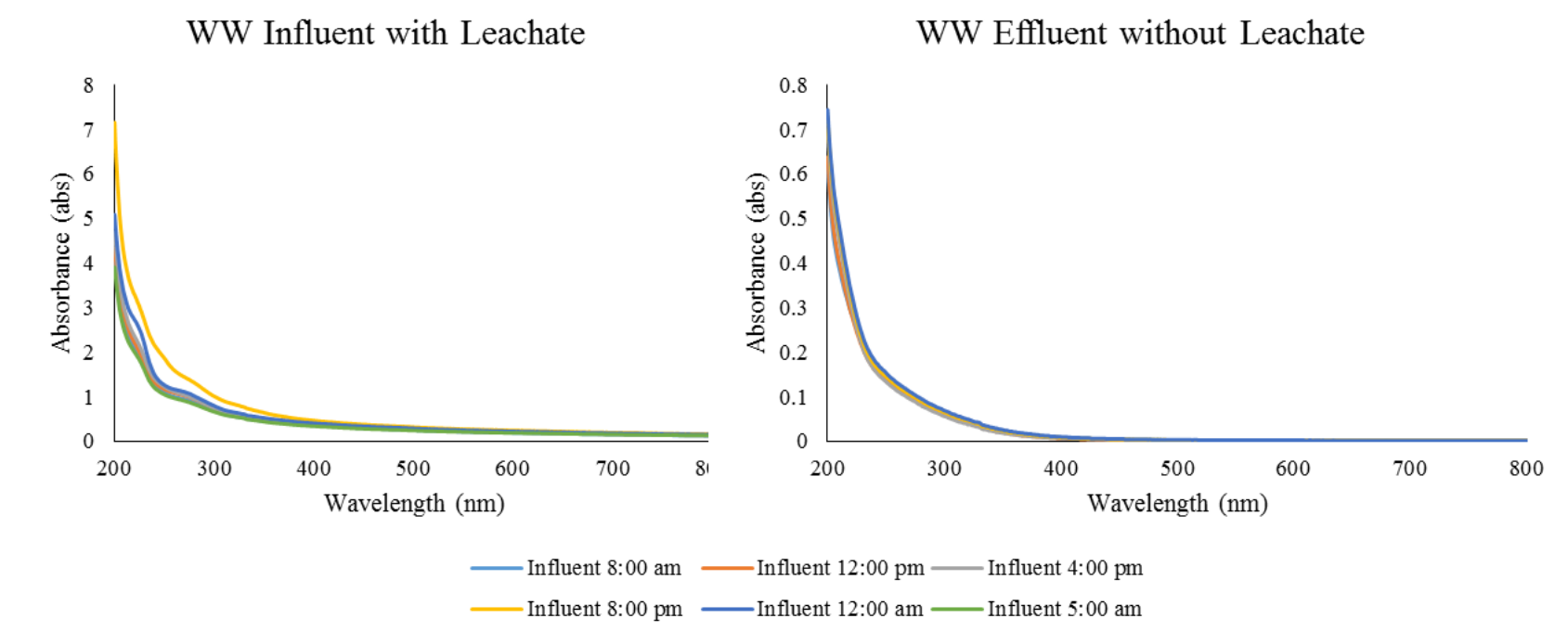

Figure 6-10. UV-Vis Scan (200 nm to $800 \mathrm{~nm}$ ) of Wastewater Influent Samples with Leachate and Effluent without Leachate (WWTP 3)

When fluorescence measurements are coupled with $\mathrm{UV}_{254} \mathrm{~nm}$ absorbance measurements the specific compounds presence in a sample can be identified. During this project, we focused on three humic-like peaks and one tryptophan/tyrosine protein-like peak. Figure 6-11 shows fluorescence data on the four peaks present in effluent samples with (black; WWTP 2B) and without leachate (dotted; WWTP 2A). Prior to analysis, all samples were diluted to a $\mathrm{UV}_{254 \mathrm{~nm}}$ of 0.01 to avoid any concentration dependent effects on fluorescence. Leachate-impacted wastewater showed a higher fluorescence which translates to a higher concentration of humiclike peaks at $350 \mathrm{~nm}$ and $312 \mathrm{~nm}$ than wastewater without leachate. The humic-like peak at 260 $\mathrm{nm}$ appears to be present in wastewater effluent with and without leachate and was only 1.22 times higher with leachate present. Lastly, the tryptophan/tyrosine-protein-like peak was approximately the same for samples with and without leachate. The literature supports that wastewater effluent fluorescence is typically dominated by protein-like organic matter (Kazner et al., 2012). Table 6-10 presents the fluorescence index (FI) of all four samples and reveals that the organic matter present in both samples was autochthonous (microbial originating) in nature (FI 
of 1.7- 2.0) (Kazner et al., 2012). There was a slight increase in the FI of the leachate-impacted samples relative to wastewater only. Since these samples were analyzed at the same $U_{2} 54 \mathrm{~nm}$ this increase could be significant.

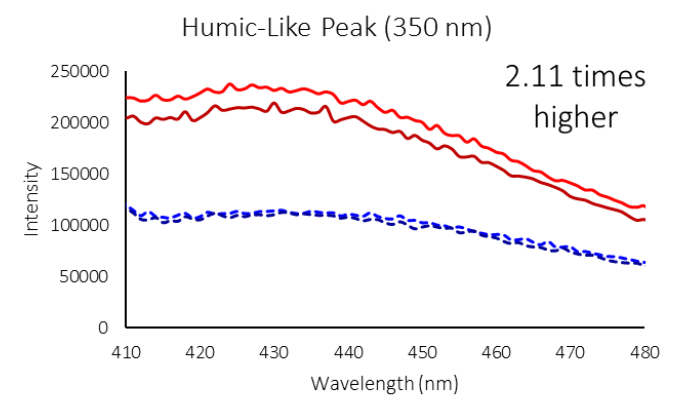

Marine-Like Humic Acid (312 nm)

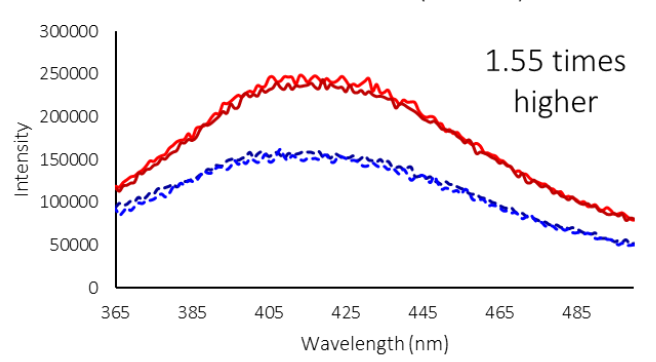

--- WW without Leachate 12 am ---WW without Leachate 4 am

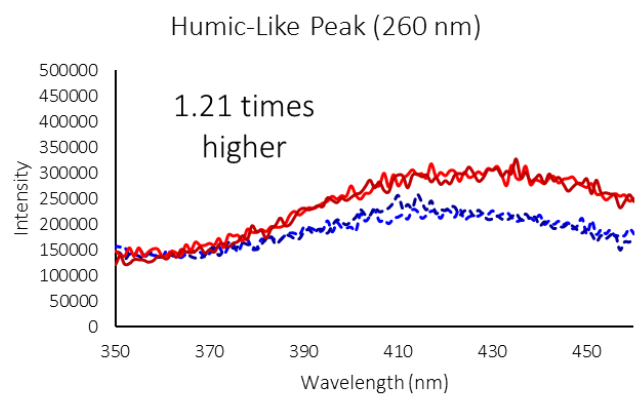

Tryptophan/Tyrosine-Protein-Like Material $(275 \mathrm{~nm})$

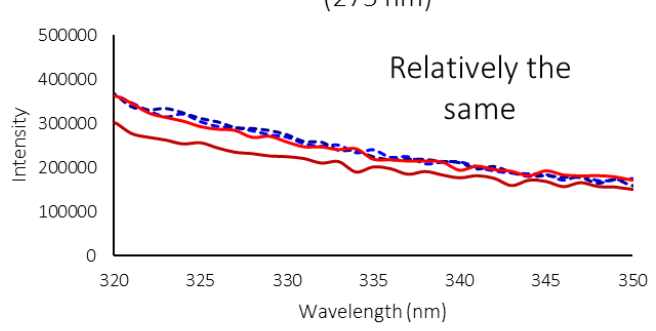

WW with Leachate $12 \mathrm{am} \longrightarrow$ WW with Leachate 4 am

Figure 6-11. Excitation-Emission Figures for WWTP 2A and 2B (with leachate) Effluent Samples Collected at 12:00 am and 4:00 am 
Table 6-11 summarizes the characteristics of wastewater effluent samples with and without leachate. Our data show that $\mathrm{UV}_{254 \mathrm{~nm}}$ absorbance and FI were higher for leachate-impacted samples, and an increase in color and DOC was observed. A clear separation between leachate impacted wastewater effluents is illustrated in Figure 6-12 by plotting color, $\mathrm{UV}_{254 \mathrm{~nm}}$ absorbance, and FI for the two sampling events at $12 \mathrm{am}$ and $4 \mathrm{am}$.

Table 6-10. Summary of Effluent Characteristics of Samples Collected at 12:00 am and 4:00 am from WWTPs 2A (without leachate) and 2B (with leachate)

\begin{tabular}{|c|c|c|c|c|c|c|c|c|}
\hline \multirow{2}{*}{ Sample } & \multicolumn{2}{|c|}{ Color (Pt-Co units) } & \multicolumn{2}{c|}{$\mathrm{UV}_{254}(\mathrm{abs})$} & \multicolumn{2}{c|}{ FI (unitless) } & \multicolumn{2}{c|}{ DOC (mg-C/L) } \\
\cline { 2 - 9 } & $2 \mathrm{~A}$ & $2 \mathrm{~B}$ & $2 \mathrm{~A}$ & $2 \mathrm{~B}$ & $2 \mathrm{~A}$ & $2 \mathrm{~B}$ & $2 \mathrm{~A}$ & $2 \mathrm{~B}$ \\
\hline $12: 00 \mathrm{am}$ & 1.18 & 34.5 & 0.13 & 0.256 & 2.3 & 2.5 & 8.02 & 9.65 \\
\hline $4: 00 \mathrm{am}$ & 23.4 & 27.1 & 0.13 & 0.256 & 2.2 & 2.5 & 8.17 & 11.4 \\
\hline
\end{tabular}

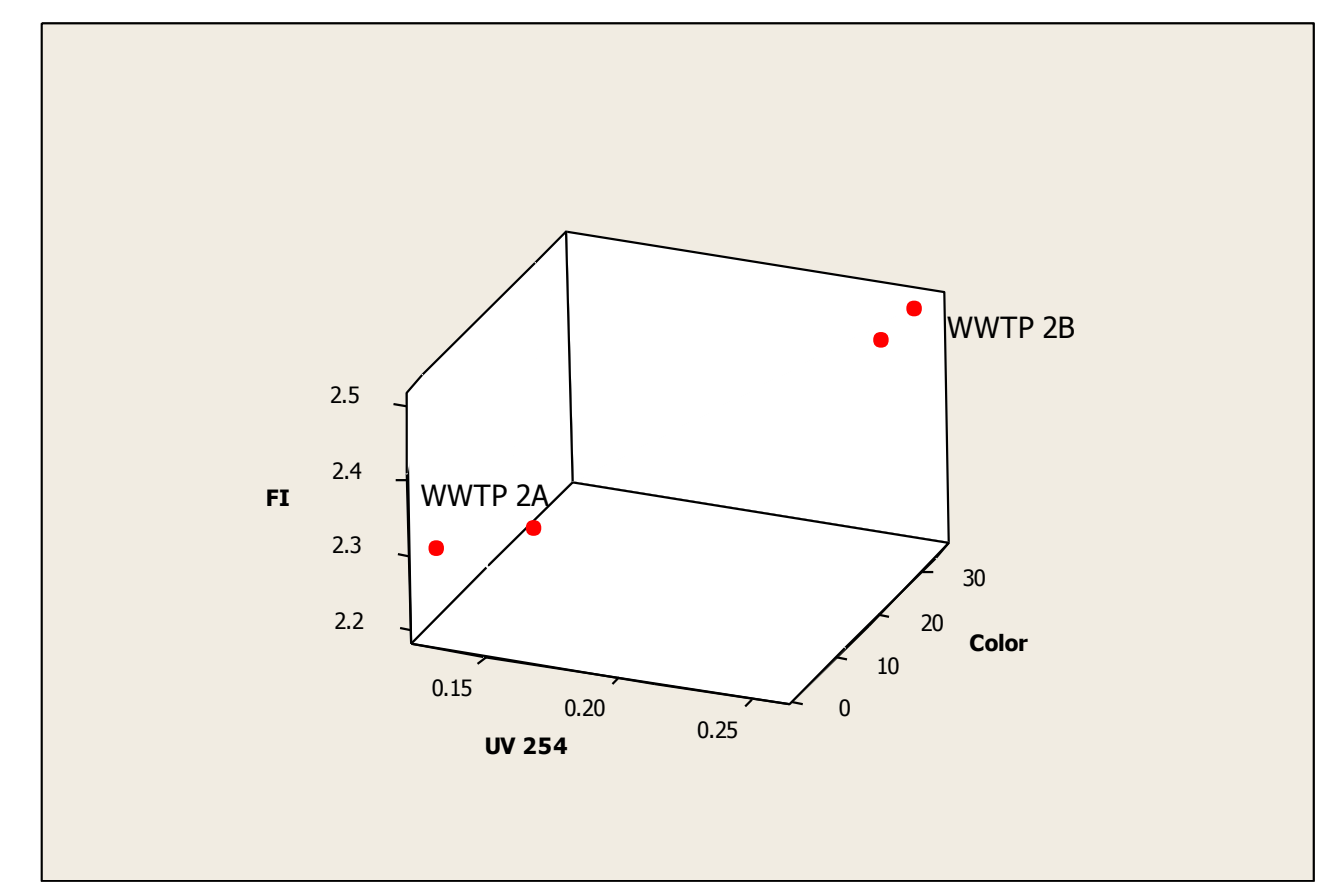

Figure 6-12. Relationship between FI, $\mathrm{UV}_{254 \mathrm{~nm}}$, and Color for Wastewater Effluent with (2B) and without (2A) Leachate 


\section{$\underline{\text { Conclusions }}$}

WWTP operators are cautious when accepting leachate because the variability in characteristics and flows could lead to increased complexity for domestic wastewater treatment (e.g., potential pass through of constituents leading to permit violations, inhibition of biological processes). This research provided a better understanding of potential implications of accepting leachate for both the landfill and WWTP operators.

Leachate was detectable in wastewater influents at dilutions below $0.01 \%$ by volume. In effluents, the UV transmittance was just below the minimum $65 \%$ necessary to meet the disinfection requirement (i.e., if membrane filtration is utilized) of less than 200 fecal coliform values per $100 \mathrm{~mL}$ for reuse (F.A.C 62-600.440; National Water Research Institute, 2012) at dilutions greater than $1 \%$. The field study of leachate co-treatment with wastewater showed that leachate detection for each field study could be determined using $\mathrm{UV}_{254}$ absorbance measurements. Each sample with a significant increase in absorbance, relative to samples without leachate, was identified as a leachate detection and subsequent impacts were further evaluated. Changes in influent characteristics were observed for all three WWTPs receiving leachate; however leachate was only evident in one effluent (WWTP 2B).

Effluent impacts were detected based on $\mathrm{UV}_{254}$ absorbance and confirmed through visual observation and apparent color measurements. When comparing the leachate-impacted samples for WWTP 2B to non-impacted samples during the same sampling event, DON, sCOD, and DOC were significantly impacted (normalized values were greater than 1). The DON ratio decreased through the WWTP suggesting that this parameter was effectively removed in the plant (WWTP 2B), while DOC persisted. DOC pass-through coincided with an increase in color and UV absorption. 
Spectral characteristics showed that leachate arrival during a sampling event led to a UV spectral due to an increase in $\mathrm{UV}_{254} \mathrm{~nm}$ absorbance, leachate-impacted wastewater showed a higher concentration of humic-like peaks during fluorescence measurements than wastewater without leachate, and $\mathrm{UV}_{254 \mathrm{~nm}}$ absorbance and a fluorescence index were higher for leachateimpacted samples and an increase in color and DOC was observed.

It is apparent from this study that leachate can have significant effects on wastewater quality at relatively low volumetric contributions. These effects were detected by a decrease in UV transmittance and color (which can interfere with disinfection), an increase in effluent DOC which can lead to violations in permits or the production of DBPs, and an increase in influent DON. These effects, however, can be managed by ensuring that leachate discharge is maintained at acceptable dilution ratios and evenly spread out over the discharge period. 


\section{$\underline{\text { References }}$}

Batarseh, Reinhart, D., \& Daly, L. (2007). Liquid Sodium Ferrate and Fenton's Reagent for Treatment of Mature Landfill Leachate. Journal of Environmental Engineering, 133(11), 1042-1050. doi: doi:10.1061/(ASCE)0733-9372(2007)133:11(1042)

Cecen, F., \& Cakiroglu, D. (2001). Impact of landfill leachate on the co-treatment of domestic wastewater. Biotechnology Letters(9), 821.

Chin, Y.-P., Aiken, G., \& O'Loughlin, E. (1994). Molecular Weight, Polydispersity, and Spectroscopic Properties of Aquatic Humic Substances. Environmental Science \& Technology, 28(11), 1853-1858. doi: 10.1021/es00060a015

Ehrig, H.-J., \& Krümpelbeck, I. (2001). The emission behaviour of old landfills in the aftercare phase. Paper presented at the Sardinia Symposium, Sardinia, Italy.

Ehrig, H. J. (1984). Treatment of sanitary landfill leachate: Biological treatment. Waste Management \& Research, 2(2), 131-152. doi: http://dx.doi.org/10.1016/0734242X(84)90136-8

Kazner, C., Wintgens, T., \& Dillon, P. (2012). Water Reclamation Technologies for Safe Managed Aquifer Recharge (1st ed.): IWA.

Kjeldsen, P., Barlaz, M. A., Rooker, A. P., Baun, A., Ledin, A., \& Christensen, T. H. (2002). Present and Long-Term Composition of MSW Landfill Leachate: A Review. Critical Reviews in Environmental Science and Technology, 32(4), 297-336. doi: 10.1080/10643380290813462

Morris, J. W. F., Vasuki, N. C., Baker, J. A., \& Pendleton, C. H. (2003). Findings from longterm monitoring studies at MSW landfill facilities with leachate recirculation. Waste Management, 23(7), 653-666. doi: http://dx.doi.org/10.1016/S0956-053X(03)00098-9

Reinhart, D. R., Dietz, J. D., Tunnell, L. G., \& Christodoulou, A. (1994). Landfill leachate treatment for biological nutrient removal from wastewater. International Journal of Environment and Pollution, 4(1), 97-106. doi: 10.1504/IJEP.1994.028350

Robinson, H., Carbille, M., Harris, G., Steward, R., \& Robinson, T. (2013, October 3, 2013). Incorporation of ultrafiltration membranes into aerobic biological treatment of landfill leachates. Paper presented at the Fourteenth International Waste Management and Landfill Symposium, Sardinia, Italy.

Worrell, W. A., Reinhart, D. R., \& Vesilind, P. A. (2002). Solid waste engineering. United Kingdom: Brooks $\backslash$ Cole. 


\section{CHAPTER 7}

\section{CONCLUSIONS AND RECOMMENDATIONS}

\section{Conclusions}

Results supported that going beyond the bioreactor landfill can further stabilize solid waste as well as reduce leachate contaminants using FB approaches. Solid waste was stabilized as indicated by a reduction in biodegradable solids, $\mathrm{C} / \mathrm{L},(\mathrm{C}+\mathrm{H}) / \mathrm{L}$, and methane potential. Based on these results aeration did not impact solid waste degradation but was effective at oxidizing ammonia-N. Alone, the leachate BOD/COD $<0.10$ was not a proper indicator of stabilization as there was still a significant pollution potential (i.e., leachate COD and ammonia-N). Ammonia-N removal was possible through flushing which is costly. In-situ aeration of the top half of the waste layer was effective at oxidizing ammonia-N but also promoted denitrification in the lower layer. Anammox bacteria were present in the aerated FBs. COD was removed through flushing and chemical oxidation. Despite this further stabilization, solid waste and leachate components still remained and additional costs would be considerable. However, additional costs could be recovered through a reduction in post-closure care period and monitoring requirements. These results show that under extensive treatment the waste and leachate characteristics did meet published stability values. A biodegradable volatile solids content of $17 \%$ dry matter, $\mathrm{C} / \mathrm{L}$ of 0.31 , and a $\mathrm{BMP}_{21}$ of $3.6 \mathrm{~m}^{3} \mathrm{CH}_{4} / \mathrm{Mg}$ waste were the minimum values that could be achieved by flushing. In terms of leachate quality, COD, BOD, and ammonia-nitrogen concentrations of 9 $\mathrm{mg} / \mathrm{L}, 150 \mathrm{mg} / \mathrm{L}$, and $7 \mathrm{mg} / \mathrm{L}$, respectively, can be achieved by operating a landfill using the flushing approach with just water. 
Results in Chapter 3 supported that the solid waste was stabilized and leachate quality was improved through FB treatment. FTIR was used to further characterize the changes occurring in the waste and leachate during these treatments. The specific functional groups and their changes were determined. This research provided a better understanding of changes in waste characteristics when waste transitions from mature to stable under extensive treatment. The stability of waste was not indicated by leachate quality alone. Changes in the solid waste occurred while $\mathrm{BOD}_{5} / \mathrm{COD}$ in FBs 1 and 2 did not change significantly. The leachate $\mathrm{BOD}_{5} / \mathrm{COD}$ in FB 3 decreased by an order of magnitude due to aeration but changes in the waste, relative to FBs 1 and 2, were not observed. FTIR is a simple tool that revealed changes in waste stability (i.e., shift from dominance of organic to inorganic functional groups) while changes in conventional parameters were minimal (e.g., BOD $/$ COD). Additional study of conventional parameters and their correlation with the changes in the FTIR spectra to waste stability is needed. The PCA tool discussed in this study was used to better understand waste stability trends.

Leachate generated in this study contained high concentrations of COD, TN, and ammonia-N prior to FB treatment. Due to the maturity of this leachate, conventional biological treatment would be ineffective at treating these samples. Nitrogen loading from leachate may be problematic for WWTPs trying to meet low TN limits. The organic matter present in leachate has also been shown to directly interfere with UV disinfection. Twelve leachates from landfills in Florida and California were collected and characterized. Chapter 5 focused on TN and DON concentrations in leachate and wastewater effluent. DON has not been widely quantified in leachate as it is not required as part of the permitted monitoring requirements. This nitrogen species is important as it can pass through the treatment processes and be a significant fraction of 
the effluent TN at WWTPs. This study provided data on the concentrations of TN and DON in leachate and the fractionation of rDON and bDON based on hydrophilic and hydrophobic properties. The average concentration of $\mathrm{TN}$ and $\mathrm{DON}$ in leachate was approximately 1,160 $\mathrm{mg} / \mathrm{L}$ and $40.7 \mathrm{mg} / \mathrm{L}$, respectively. The average concentrations of bDON and rDON was 16.5 $\mathrm{mg} / \mathrm{L}$ and $18.4 \mathrm{mg} / \mathrm{L}$, respectively. Understanding the distribution of each fraction relative to leachate characteristics was important to estimate the potential treatability of landfill leachate and pass through to the environment. It was observed that at a $10 \%$ leachate volumetric contribution, WWTPs, under some circumstances, were able to meet a TN discharge limit of 10 $\mathrm{mg} / \mathrm{L}$, but not $3 \mathrm{mg} / \mathrm{L}$. It was estimated that the pass through of leachate rDON and DON was significant and could contribute to TN permit violations. There is potential for these nitrogen species to become bioavailable once discharged to aquatic systems. Pretreatment of leachate can reduce nitrogen loadings to WWTPs and the discharge to aquatic systems.

Results from Chapter 5 supported the need to conduct field studies on the fate of leachate organic matter at WWTPs. This research provided a better understanding of the potential implications of accepting leachate for both the landfill and WWTP operators. Leachate was detectable in wastewater influents using $\mathrm{UV}_{254 \mathrm{~nm}}$ absorbance at dilutions below $0.01 \%$ by volume. In effluents, the UV transmittance was just below the minimum $65 \%$ necessary to meet the disinfection requirement (i.e., if membrane filtration is utilized) of less than 200 fecal coliform values per 100 mL for reuse (F.A.C 62-600.440; National Water Research Institute, 2012) at dilutions greater than $1 \%$. The field study of leachate co-treatment with wastewater showed that leachate could be detected using $\mathrm{UV}_{254}$ absorbance measurements. Changes in influent characteristics were observed for all three WWTPs receiving leachate; however leachate was only evident in one effluent (WWTP 2B) based on $\mathrm{UV}_{254}$ absorbance, confirmed through 
visual observation and apparent color measurements. When comparing the leachate-impacted samples for WWTP 2B to non-impacted samples during the same sampling event, DON, sCOD, and DOC were significantly affected (normalized concentration values were greater than 1). DON decreased through the WWTP suggesting that this parameter was effectively removed in the plant (WWTP 2B), while DOC persisted. DOC pass through coincided with an increase in color and UV absorption.

Spectral characteristics showed that leachate arrival during a sampling event led to a UV spectral shifts due to an increase in $\mathrm{UV}_{254} \mathrm{~nm}$ absorbance. Leachate-impacted wastewater showed a higher concentration of humic-like peaks during fluorescence measurements than wastewater without leachate, $\mathrm{UV}_{254 \mathrm{~nm}}$ absorbance and a fluorescence index were higher for leachateimpacted samples, and an increase in color and DOC was observed. It is apparent from this study that leachate can have significant effects on wastewater quality at relatively low volumetric contributions. These effects were detected by a decrease in UV transmittance and an increase in color (which can interfere with disinfection), an increase in effluent DOC which can lead to violations in permits to the production of DBPs, and an increase in influent DON. These effects, however, can be managed by ensuring that leachate discharge is maintained at acceptable dilution ratios and evenly spread out over the discharge period. 


\section{$\underline{\text { Recommendations }}$}

Results from this study suggest that the FB treatments further stabilized solid waste and improved leachate quality. Additional treatment is required beyond closure to ensure that waste is stabilized and the site is safe without active care. At some point in time there will be a breach in the containment systems and landfills will be a significant source of pollution in the future. A conventional landfill could be retrofitted for leachate injection but the further stabilization of solid waste can potentially compromise the integrity of the final cover system due to subsidence. Therefore it would be suggested that leachate injection should occur before the final cover is installed. Another option could be installing a temporary permeable cover which will allow for infiltration of liquid through the landfill after closure. The time required to meet a sufficient L/S (e.g. L/S of 10) would be longer versus active liquid injection but the solid waste would continue to stabilize without added infrastructure. An additional benefit of a permeable cover is the cost savings of utilizing liquid from precipitation as opposed to potable water.

Field studies of the three FB treatments are needed to determine the extent of waste stabilization that can be achieved relative to the laboratory. These fields studies would be necessary to understand the effects of hydraulic conductivity and the zone of influence for in-situ aeration. The extent of treatment achieved in the FBs was related to the $\mathrm{L} / \mathrm{S}$ and the field L/S would need to be determined at a landfill. The field L/S could be used to gauge how much treatment has already been achieved and then how much liquid would need to be applied to reach a desired level of treatment. The level of treatment would be based on regulatory target values to release a landfill from PCC.

The characterization of solid waste and leachate using FTIR shed some light on the ability to utilize this non-destructive technique but additional data is required to fully implement this 
technique in the field. In this study there was a lack of samples during the initial anaerobic treatment. Laboratory-scale anaerobic bioreactors should be operated and deconstructed during the acidogenic and methanogenic phases to characterize the leachate and solid waste samples. The point at which these reactors reached acidogenic and methanogenic phases would be determined through conventional leachate characterization (e.g, BOD/COD and $\mathrm{pH}$ ). Once these samples are generated and analyzed, a FTIR library could be developed of fresh, aciodgenic, methanogenic, mature, and stabilized solid waste characteristics. This information could be used to develop a predictive model which can be applied in the field. Waste that has been excavated could quickly characterized using FTIR and the stability related to the location and waste age where samples could be obtained. The characteristics would then be compared to the FTIR database and the extent of stabilization predicted.

The characterization of leachate DON, bDON, and rDON needs to be expanded to include samples from landfills in various climates and waste collection practices (e.g., increase in waste diversion, banning of organics). Chemical oxidation or pretreatment methods could be used to remove DON from leachate prior to discharging to a WWTP. Chemical oxidation could be an upstream process geared towards reducing the organic loadings to increase the efficiency of physical processes, such as membrane filtration. The removal of leachate DON during wastewater treatment has not been documented. This information is important to improve understanding of the impact of leachate on WWTP effluent quality. The production of rDON during biological treatment should be considered.

Leachate discharge data needs to be improved to better understand the hourly impacts on wastewater influent and effluent quality. This information is necessary to refine the recommendation on the allowable volumetric contribution of leachate to avoid negatively 
impacting UV disinfection and effluent quality. UV absorbance at $254 \mathrm{~nm}$ has the potential to detect leachate in influent and effluent samples. The change in UV absorbance in the influent could give operators a better idea of how much leachate is being received and the treatment processes could be adjusted accordingly (e.g., increase in air or divert flow to an equalization basin). UV technology is already available as an in-line meter for WWTPs. 
APPENDIX B

METHODOLOGY 
The ability to achieve sustainable landfilling by removing releasable carbon (recalcitrant) and ammonia-nitrogen at the end of a landfill life was evaluated by operating and monitoring flushing bioreactors (FBs), which includes conducting laboratory tests to determine the chemical group and structural (molecular) changes in the solid waste, leachate, and HA. The methodology used to achieve the research objectives included: creating a source of mature waste, operating FBs, characterizing chemical and structural (molecular) changes of solid waste, leachate, and $\mathrm{HA}$, and determining the effects of leachate dissolved organic nitrogen on wastewater treatment plant effluent quality.

\section{Operating Laboratory Scale Bioreactor to Create a Source of Mature Waste}

In order to simulate the three FBs a sufficient amount of mature waste was generated. It is hypothesized that a bioreactor landfill can be operated to create a source of mature stable waste based on conventional chemical and biological parameters (BOD/COD, BMP, and volatile solids) but will still have a significant leachable carbon and nitrogen content remaining. This hypothesis was tested by operating and monitoring two 121-L reactors that were designed to allow for leachate recirculation and drainage, gas collection, and the ability to test waste subsidence, as shown in Figure A-1. Reactors were constructed of HDPE and measure $56 \mathrm{~cm}$ in diameter and a height of $69 \mathrm{~cm}$ (Figure A-1). 


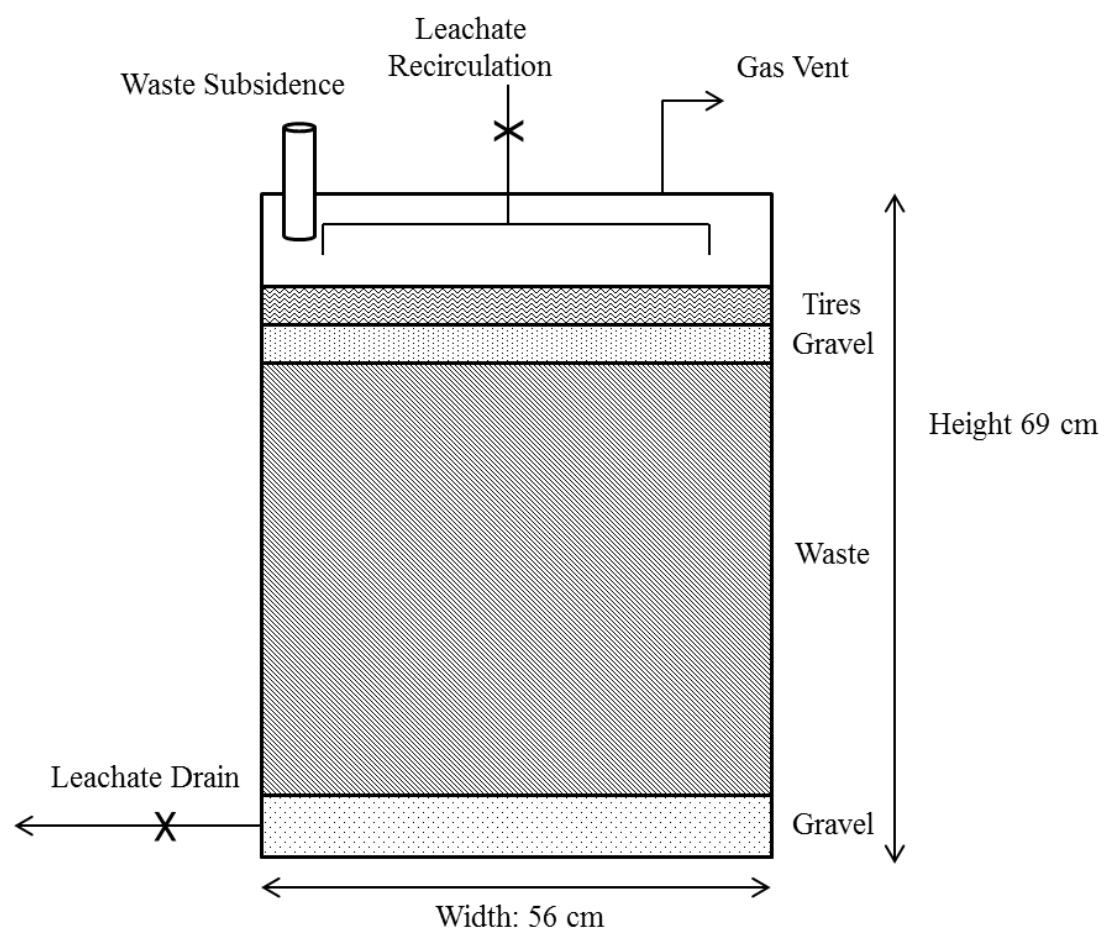

Figure B-1. Anaerobic Bioreactor Schematic

Leachate was introduced through a drilled PVC pipe grid placed under the reactor lid, ensuring equitable distribution of leachate. Leachate was drained at the bottom of the reactors which was covered with a layer of gravel to minimize clogging. The reactors were filled with synthetic waste with characteristics of a typical Florida MSW landfill shredded to $2.5 \mathrm{~cm} \times 2.5$ $\mathrm{cm}$. Synthetic waste was generated from new or post-consumer materials and used to minimize variability in reactor operation that could result from using "real" waste and to better define and understand the reactor inputs.

The waste generated for this study was approximated from the 2009 FDEP waste composition for the State of Florida (FDEP, 2011). Table A-1 compares the 2009 waste composition to the proposed waste composition that was added to both reactors. The reactors were continuously operated until a source of mature waste was achieved. 
Table B-1. Anaerobic Bioreactor and State of Florida 2009 Waste Composition (FDEP, 2011)

\begin{tabular}{|c|c|c|}
\hline Components & Florida 2009 $(\%$ by wt) & Bioreactor (\% by weight) \\
\hline Food Waste & 6.0 & 9.0 \\
\hline Plastics & 6.0 & 7.0 \\
\hline C\&D Debris & 23 & 0 \\
\hline Tires & 0 & 1.0 \\
\hline Other Paper & 20 & 30 \\
\hline Glass & 3.0 & 0 \\
\hline Metals & 14 & 12 \\
\hline Textiles & 3.0 & 4.0 \\
\hline Yard Trash & 11 & 17 \\
\hline Newspapers & 5.0 & 7.0 \\
\hline Miscellaneous & 9.0 & 13 \\
\hline
\end{tabular}

Where possible certain components were broken down into more specific subcomponents based on 2010 US EPA waste composition data (US EPA, 2011). These categories included other plastics, other paper, and non-ferrous metals. The detailed waste composition breakdown is summarized in Table A-2. Additional sub-components account for the variations in products and composition. For example the lignin content of paper varies by paper type (Eleazer et al., 1997; Stinson and Ham, 1995). Glass wAS omitted due to potential safety risks during waste mixture, placement, and future analytical tests. Shredded yard waste was collected from a processing facility in Central Florida and further processed in the laboratory by removing large pieces of debris. 
Table B-2. Waste Composition for Reactor 1

\begin{tabular}{|c|c|}
\hline Waste Composition Breakdown & Weight Added (lb) \\
\hline \multicolumn{2}{|l|}{ 1. Food Waste } \\
\hline Dog Food & 4.6 \\
\hline \multicolumn{2}{|l|}{ 2. Textiles } \\
\hline Clothing & 1.15 \\
\hline Rope & 1.15 \\
\hline \multicolumn{2}{|l|}{ 3. Miscellaneous } \\
\hline Soil & 6.9 \\
\hline \multicolumn{2}{|l|}{ 4. Glass } \\
\hline Beer and Soft Drink Bottles & $0^{1}$ \\
\hline Wine and Liquor Bottles & $0^{1}$ \\
\hline Other Bottles and Jars & $0^{1}$ \\
\hline \multicolumn{2}{|l|}{ 5. Aluminum Cans } \\
\hline Soda Cans & 0.80 \\
\hline \multicolumn{2}{|l|}{ 6. Steel Cans } \\
\hline Steel Wire & 0.80 \\
\hline \multicolumn{2}{|l|}{ 7. Plastic Bottles } \\
\hline Bottles PET/Plastic Cups (1) & 0.80 \\
\hline \multicolumn{2}{|l|}{ 8. Other Plastics } \\
\hline \multicolumn{2}{|l|}{ HDPE (2) } \\
\hline Water Jugs/Plastic Bags & 0.60 \\
\hline \multicolumn{2}{|l|}{ PVC (3) } \\
\hline PVC Pipe & 0.10 \\
\hline \multicolumn{2}{|l|}{ LDPE (4) } \\
\hline Grocery Bags & 0.80 \\
\hline \multicolumn{2}{|l|}{ Polypropylene (5) } \\
\hline Plastic Plates & 0.90 \\
\hline \multicolumn{2}{|l|}{ Polystyrene (6) } \\
\hline Styrofoam Cups & 0.25 \\
\hline \multicolumn{2}{|l|}{ Other (7) } \\
\hline$C D s$ & 0.40 \\
\hline \multicolumn{2}{|l|}{ 9. Newspapers } \\
\hline Newspapers & 3.80 \\
\hline \multicolumn{2}{|l|}{ 10. Corrugated Cardboard } \\
\hline Cardboard & 7.70 \\
\hline \multicolumn{2}{|l|}{ 11. Office Paper } \\
\hline Printer Paper & 2.30 \\
\hline
\end{tabular}




\begin{tabular}{|c|c|}
\hline 12. Other Paper & \\
\hline Mixed Paper & \\
\hline Magazines & 0.30 \\
\hline Phone Book & 0.80 \\
\hline High Grade & \\
\hline Envelopes & 0.80 \\
\hline Letterhead & 0.50 \\
\hline Other Paper & \\
\hline Notebook Paper & 1.0 \\
\hline Yellow Legal Paper & 1.0 \\
\hline Sticky Notes & 1.0 \\
\hline Glossy Paper & 0.50 \\
\hline 13. Yard Waste & \\
\hline Yard Waste & 9.20 \\
\hline 14. Ferrous Metal & \\
\hline Galvanized Steel Bolts & 3.45 \\
\hline 15. Non-Ferrous Metal & \\
\hline Copper Wire & 0.75 \\
\hline Brass Wire & 0.50 \\
\hline 16. Tires & \\
\hline Shredded Tire Mulch & 0.80 \\
\hline & 53.7 \\
\hline
\end{tabular}

1. Omitted for safety reasons.

Each waste component was individually weighed and mixed on a plastic tarp. After uniform mixing, liquid was added for a moisture content of $50 \%$ by weight (approximately 14 L). To ensure there was adequate buffering capacity and to avoid the reactors from becoming acid-stuck, sodium bicarbonate was added to $12.5 \mathrm{~L}$ of distilled (DI) water for a final concentration of $3.4 \mathrm{~g} / \mathrm{L} \mathrm{NaHCO}_{3}$. This concentration was based on a theoretical alkalinity of $2,000 \mathrm{mg} / \mathrm{L}$ as calcium carbonate. In addition to distilled water, approximately $1.5 \mathrm{~L}$ of anaerobically digested sludge, collected from a local wastewater facility, was added to provide a source of anaerobic organisms and decrease start-up time. The total liquid volume was applied to 
the waste in three aliquots and the waste mixed between additions. This process was followed for each reactor.

Waste placement was completed in small sections and compacted. A final layer of gravel and tires was added to promote uniform leachate distribution. Reactors were closed and sealed to maintain an anaerobic environment and Tedlar bags were attached to a gas sampling port for continuous gas collection. Prior to closure samples (2.7-3.2 kg of waste), from each reactor, was removed and individually analyzed for moisture and volatile solids content, and analysis of humic acid, lignin, cellulose, and hemicellulose concentrations.

Buffered distilled (DI) water was added until leachate was generated from both reactors. Leachate was drained and approximately 2.0 liters was recirculated roughly every three days. During this time leachate samples were collected from each reactor every two weeks prior to recirculation. Leachate was analyzed for $\mathrm{BOD}_{5}, \mathrm{COD}, \mathrm{pH}$, and ammonia-nitrogen following Standard Methods (APHA, 2005) and an additional $50 \mathrm{~mL}$ aliquot of leachate was dried and analyzed using FTIR. To ensure that a sufficient volume of leachate was available for recirculation $(2.0 \mathrm{~L})$, DI water was occasionally added to compensate for leachate lost through sampling.

\section{Operation of Flushing Bioreactors}

This task investigates the three FB process (Figure A-2) to evaluate the technical feasibility of leaching organic contaminants for ex-situ oxidation and removal of ammonianitrogen facilitated by in-situ oxidation. The goal of this task was to achieve sustainable landfilling by removing releasable recalcitrant carbon and ammonia-nitrogen at the end of a bioreactor landfill life, reducing long term environmental threat. It is hypothesized that the 
STABL scenario will achieve a reduction in leachate ammonia-nitrogen and COD at a lower liquid addition in comparison to flushing and chemical oxidation only.

Mature waste was removed from the laboratory bioreactors, after the analysis of gas, leachate, and solids confirmed a well-degraded state was achieved. Four $\mathrm{kg}$ of wet waste was placed in each of eighteen reactors representing the following three scenarios, (1) flushing with clean water (FB 1), (2) recirculation of leachate, external leachate oxidation, with no internal oxidation (FB 2), and (3) recirculation of leachate, external leachate oxidation, and internal oxidation (FB 3), as shown in Figure A-2. The different scenarios will provide the information necessary to make a comparison of the effectiveness of the STABL (FB 3) with flushing (FB 1) and chemical oxidation only (FB 2).

Flushing bioreactors (FBs 1-3) wERE constructed from high-density polyethylene (HDPE) containers and were modified for leachate drainage and recirculation (FB 1-3), and air addition (FB 3 only), as shown in Figure A-2. An aquarium compressor was used to inject air into FB 3 for continuous aeration. Air movement was countercurrent to leachate injection through a vertical perforated pipe. 

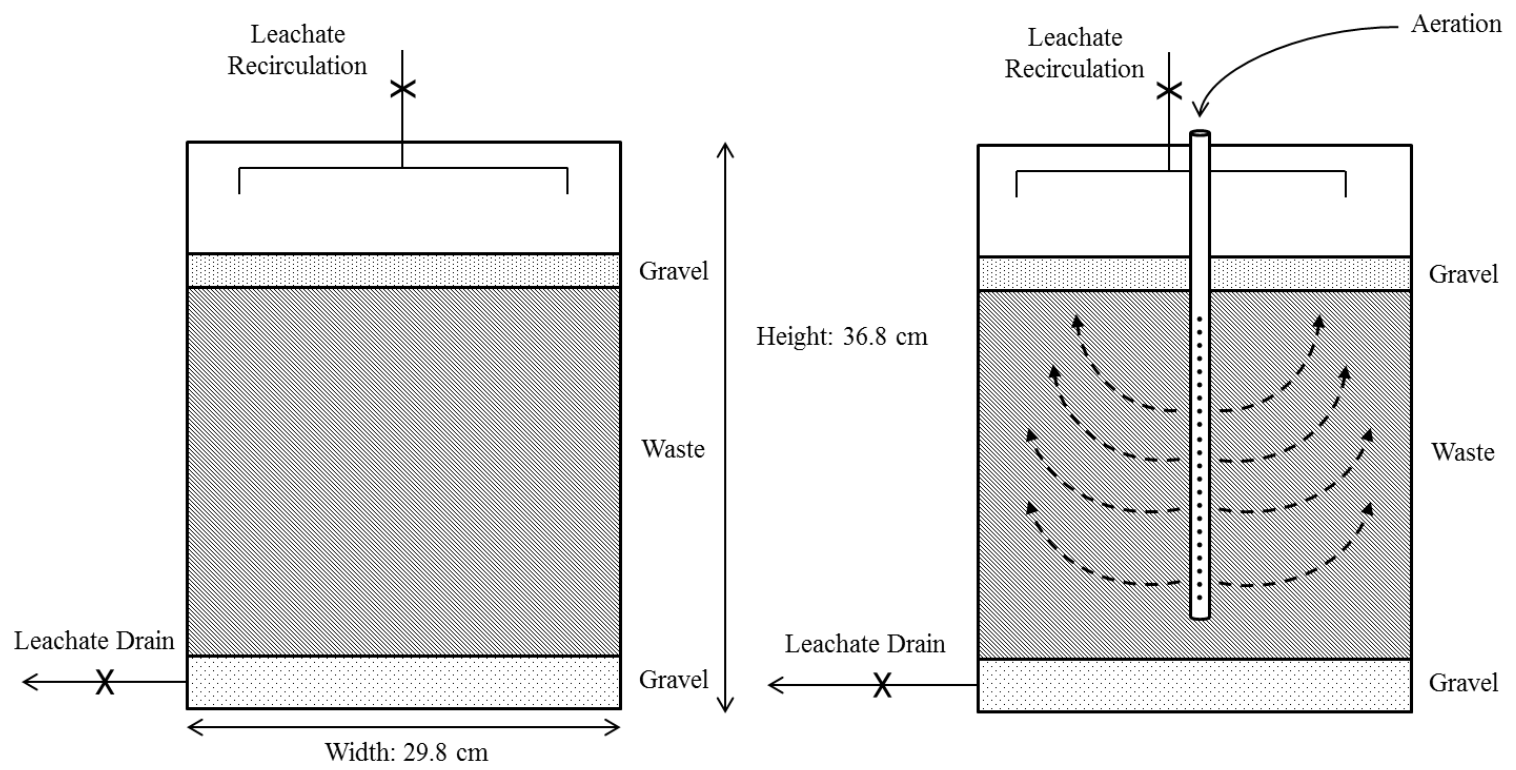

Figure B-2. Design that Represents the Three Flushing Bioreactor Scenarios (A) FBs 1 and 2 (B) Pilot Scale STABL (FB 3)

Leachate generated from the initial bioreactors (Task 1) was added to begin the flushing process (only distilled water will be added to FB 1). Reactors were placed in a temperaturecontrolled room maintained at $35^{\circ} \mathrm{C} \pm 2$. A total of six reactors for each $\mathrm{FB}$ scenario were operated under identical conditions; however, one set was deconstructed after two months (six total) in order to evaluate the characteristics of solid waste at different waste degradation phases, with the remaining reactors deconstructed after four and six months. The hypothesistested was a reduction in $\mathrm{C}$ and $\mathrm{N}$ will be achievable in the flushing bioreactor scenarios but will require a larger volume of liquid and external treatment, relative to STABL and chemical oxidation only.

FB 1 was flushed with DI water three times per week. Leachate from FBs 2-3 was recirculated three times per week and leachate from FBs 2 and 3 was treated with Fenton's Reagent weekly. Detailed methodology for Fenton's Reagent treatment is summarized in Appendix B. Leachate was tested for $\mathrm{COD}, \mathrm{BOD}_{5}, \mathrm{pH}$, and ammonia-nitrogen according to Standard Methods (2005). 
The HA evolution (production) was characterized to monitor the stabilization of the waste. HA was extracted from each of the sacrificed reactors every two months. Solid and liquid phase extraction followed the method, which was adapted from Swift (1996), except for the sample preparation required for solid waste samples. The HA extraction is described in Appendix B.

To evaluate the changes in the organic waste during biological decomposition, samples of the waste from the deconstructed reactors were removed and the following tests conducted: volatile solids, biochemical methane potential (BMP), cellulose, hemicellulose, and lignin content (by an outside lab). Gas quality from the BMP tests was monitored for methane and carbon dioxide, respectively, using a Gas Chromatograph equipped with a Thermal Conductivity Detector (Appendix B). Organic content determined directly or indirectly from these techniques was correlated with stages of degradation, leachate characteristics, and pollutant leachability.

\section{Chemical Group and Structural (Molecular) Changes in Solid Waste and Leachate}

The chemical groups and structural (molecular) changes in solid waste and leachate samples during waste stabilization was characterized using FTIR. This spectroscopy method characterizes the spectral bands present from both specific chemical compounds (alcohols, benzene, phenol, water) and classes of compounds (aromatics, acids, esters, amides, aliphates) (Kalisz et al., 2008). Solid waste and solids derived from leachate samples will be removed from laboratory scale bioreactors and from the FBs.

Solid waste samples were dried at $105^{\circ} \mathrm{C}$ overnight and milled to pass through a $2.0 \mathrm{~mm}$ sieve. Additionally, $50 \mathrm{~mL}$ of leachate from each reactor was collected and dried at $105^{\circ} \mathrm{C}$ overnight in a beaker. The powder collected from both solid waste (dried and inorganic fraction) and leachate samples were stored in glass vials until further analysis. 
Sample powders were analyzed using a Perkin Elmer Spectrum 100 Series FTIR. A background scan was taken before each analysis to remove any contribution of air from the spectrum. A spectrum was acquired by placing a small amount of powder on the sample holder then applying the pressure arm until the force gauge reads approximately 80 . Three spectrums were acquired for all samples. Transmittance peaks were labeled and identified based on published assignments for FTIR spectral peaks.

HA samples were characterized using Nuclear Magnetic Resonance (NMR) to determine the carbon $(13 \mathrm{C})$ chemical shifts. Dried samples were dissolved in deuterium oxide $\left(\mathrm{D}_{2} \mathrm{O}\right)$ and analyzed using a Varian VNMRS 500 MHz NMR. Ultraviolet-Visible Spectroscopy will be used to measure the absorbed energy based on the electronic transition in the molecule. HA was dissolved in DI water and an aliquot of this suspension was placed in a $1.0 \mathrm{~cm}$ cell and the absorbance was measured at $465 \mathrm{~nm}$ and $665 \mathrm{~nm}$ using a HACH DR-5000 UV-Vis Spectrophotometer. FTIR was used to characterize the chemical and functional groups of the extracted HA. Spectral peaks were acquired using a Perkin Elmer Spectrum 100 Series FTIR. 


\section{APPENDIX C}

\section{ANALYTICAL METHODS}




\section{Fenton's Reagent Treatment}

When leachate is treated with Fenton's Reagent, the collected leachate from FBs 2 and 3

will be adjusted to a $\mathrm{pH}$ of $4.0 \mathrm{~S}$.U. with $6 \mathrm{~N}$ hydrochloric acid, after which ferrous chloride $(0.4$ Fe to $\mathrm{H}_{2} \mathrm{O}_{2}$ ) and $50 \%$ hydrogen peroxide $\left(1 \mathrm{~g} \mathrm{H}_{2} \mathrm{O}_{2}: \mathrm{g} \mathrm{COD}\right)$ is added to the leachate. The reaction was allowed to proceed under continuously stirred conditions for 60 minutes (at room temperature $24^{\circ} \mathrm{C}$ ). During this time hydrogen peroxide indicator strips were used to monitor the residual hydrogen peroxide throughout the duration of the reaction. After confirming that the residual hydrogen peroxide is absent the treated leachate $\mathrm{pH}$ was brought back up to 7.0 S.U. using $6 \mathrm{~N}$ sodium hydroxide and set aside for settling. After settling is complete leachate was then centrifuged for ten minutes and then filtered $(1.5 \mu \mathrm{m}$ Whatman 934-AH glass filter) to remove the precipitated solids. The precipitates were dried and stored for future analysis (FTIR). Aliquots of the treated (unfiltered) and filtered leachate were removed for COD and TOC analysis. To remove the interference from chloride, which is added to the system from ferrous chloride and hydrochloric acid, mercuric sulfate $(0.50 \mathrm{~g})$ was added to each COD vial. This reagent removes up to $1,000 \mathrm{mg} / \mathrm{L}$ of chloride inference.

\section{Humic Acid Extraction}

The evolution (production) of HA has been an indicator of the extent of waste stabilization in landfills, composting, and wastewater sludge (Nanny and Ratasuk, 2002). The evolution of HA is evaluated by determining the change in concentration and the extent of humification using spectral properties. The increase in HA concentration has been shown to increase as waste is stabilized. HA was extracted from solid waste samples as one indicator of stabilization for each 
FB scenario. The extraction procedure is based on a modified method to isolate HA and fulvic acid (FA) from solid-phase materials (IHSS, 2007).

Twenty grams of the milled samples were placed in a 500-mL Erlenmeyer flask and the $\mathrm{pH}$ was equilibrated to $2.0 \mathrm{~S}$.U. with $1 \mathrm{M} \mathrm{HCl}$ at room temperature $\left(\sim 24^{\circ} \mathrm{C}\right)$. The final volume was adjusted to a volume to solids ratio of $10 \mathrm{~mL}$ of liquid per $1.0 \mathrm{~g}$ of solid waste with $0.1 \mathrm{M} \mathrm{HCl}$. Each flask was placed on a shaker table, at 200 RPM, for approximately one hour. Each suspension was decanted for 30 minutes to separate the FA (supernatant) and HA (residue) fractions. Supernatant was discarded after decanting. The residue was neutralized with $1 \mathrm{M}$ $\mathrm{NaOH}$ to a pH of 7.0 S.U. followed by the addition of $0.1 \mathrm{M} \mathrm{NaOH}$ for 10:1 final extractant to residue ratio. This neutralized fraction was intermittently shaken, every 15 minutes, for approximately four hours. The solution was then allowed to settle overnight, centrifuged (4000 RPM for 10 minutes), and the supernatant was collected (HA). In order to precipitate out the HA fraction, the supernatant was acidified with $6 \mathrm{M} \mathrm{HCl}$ (final $\mathrm{pH}$ of $1.0 \mathrm{~S} . \mathrm{U}$.), under continuous shaking, after which the suspension settled for approximately 12 to 16 hours. The HA fraction was collected and suspended in a minimal volume of DI water. The HA suspension was dialyzed against DI water using pre-wetted dialysis tubing with a 1,000 dalton molecular weight cut-off (Spectrums Lab \#132640) for a 48-hour period (DI was replaced after 24 hours). The final HA extraction was dried overnight at $105^{\circ} \mathrm{C}$ and placed in a desiccator for further analysis. 


\section{Biochemical Methane Potential}

The BMP was determined following ASTM method E2170 (Owen, 1979). This test is traditionally used for liquid samples but has been modified and used to evaluate the methane potential of solid waste samples (Bergman, 1996, Bogner, 1990, Owens and Chynowth, 1992). An anaerobic inoculum medium was prepared by combining anaerobically digested sludge obtained from a local domestic wastewater treatment facility and necessary nutrients that are required to sustain an anaerobic environment for at least 90 days. BMP assays were prepared individually in 250-mL serum bottles processed under anaerobic conditions (maintained through continuous $\mathrm{N}_{2}$ flushing). Serum bottles were filled with $5.0 \mathrm{~g}$ dry milled solid waste samples after which $150 \mathrm{~mL}$ of anaerobic inoculum was added, using a peristaltic pump. All bottles were sealed with a rubber stopper and aluminum crimp, and incubated at $35 \pm 2{ }^{\circ} \mathrm{C}$ for 90 days.

Gas quality and quantity was measured periodically over a 90 day period. Gas samples were removed periodically during this period with a frictionless syringe to measure $\mathrm{CO}_{2}$ and $\mathrm{CH}_{4}$ in the gas phase. The gas quality was measured using a Shimadzu - 14 gas chromatograph equipped with a TCD detector and a Carboxyn column. During analysis the detector temperature was held at $250^{\circ} \mathrm{C}$, while the injection temperature was kept at $35^{\circ} \mathrm{C}$ for five minutes then ramped, in $20^{\circ} \mathrm{C}$ increments, up to $225^{\circ} \mathrm{C}$ over a 16 -minute run time. 


\section{Solid-Phase Extraction of Recalcitrant Dissolved Organic Nitrogen in Leachate}

The impact on waters receiving WWTP LOM is related to the bioavailability of the material. The DON bioavailability to algae has been shown to be related to the hydrophilic nature of the material (Liu et al., 2011). Leachate was fractionated using SPE. The fractionation method is based on Liu et al. (2011) and was modified to account for the higher concentration of OM present in leachate. An acrylic ester resin (Supelite DAX-8, Sigma-Aldrich) was used to extract the hydrophobic DON. This specific fraction retained on the resin is considered to be rDON. Supelite DAX-8 resin is commonly used to extract fulvic and humic acids and will retain compounds up to 150,000 molecular weight (MW) (Liu et al., 2011). Resin was cleaned with 0.1 $\mathrm{M} \mathrm{NaOH}$ for three days ( $\mathrm{NaOH}$ will be replaced every 24 hours), rinsed with methanol, and finally suspended in DI water. A glass column (1.0 cm diameter, $30 \mathrm{~cm}$ length, Kimble-Chase) was packed with $20 \mathrm{~g}$ of cleaned resin in $100 \mathrm{~mL}$ of $\mathrm{DI}$ for a final volume of approximately 20 $\mathrm{mL}$. Prior to fractionation, the column was conditioned following the method outlined in Liu et al., (2011).

Leachate samples were filtered using a $0.45-\mu \mathrm{m}$ filter and then acidified with $6 \mathrm{~N} \mathrm{HCl}$ to a pH of 2.0 S.U. A peristaltic pump was used to introduce the acidified sample through the column at a flow rate of $1 \mathrm{~mL} / \mathrm{min}$. Prior to pumping leachate through the column, the samples were diluted deioned (DI) water to ensure all of the liquid moves through the packed bed volume. Two fractions were generated: an unbound (flow through, hydrophilic) fraction and a bound fraction that elutes with $0.1 \mathrm{M} \mathrm{NaOH}$ (hydrophobic). The latter fraction was eluted in the reverse direction with $100 \mathrm{~mL}$ of $\mathrm{NaOH}$. The $\mathrm{DON}, \mathrm{COD}$, color, and $\mathrm{UV}_{254 \mathrm{~nm}}$ absorbance and was determined for each fraction. 


\section{References}

IHSS. (2007). What are Humic Substances? , from http://www.humicsubstances.org/whatarehs.html

Liu, H., Jeong, J., Gray, H., Smith, S., \& Sedlak, D. L. (2011). Algal Uptake of Hydrophobic and Hydrophilic Dissolved Organic Nitrogen in Effluent from Biological Nutrient Removal Municipal Wastewater Treatment Systems. Environmental Science \& Technology, 46(2), 713-721. doi: 10.1021/es203085y

Nanny, M. A., \& Ratasuk, N. (2002). Characterization and comparison of hydrophobic neutral and hydrophobic acid dissolved organic carbon isolated from three municipal landfill leachates. Water Research, 36(6), 1572-1584. doi: http://dx.doi.org/10.1016/S0043$\underline{1354(01) 00359-1}$ 


\section{APPENDIX D}

SUPPLEMENTAL INFORMATION: APPLICATION OF LANDFILL TREATMENT APPROACHES FOR THE STABILIZATION OF MUNICIPAL SOLID WASTE 
Table D-1. Anaerobic Bioreactor Waste Composition

\begin{tabular}{|c|c|}
\hline Components & Synthetic (\% by weight) \\
\hline Food Waste & 9.0 \\
\hline Plastics $^{1}$ & 7.0 \\
\hline C\&D Debris $^{\prime}$ & 0 \\
\hline Tires & 1.0 \\
\hline Other Paper $^{2}$ & 30 \\
\hline Glass & 0 \\
\hline Metals & 12 \\
\hline Textiles & 4.0 \\
\hline Yard Waste & 17 \\
\hline Newspapers & 7.0 \\
\hline Miscellaneous & 13 \\
\hline
\end{tabular}

Included:

1. HDPE (20\%), polyvinyl chloride (PVC) (3\%), low-density polyethylene (LDPE) (28\%), polypropylene $(28 \%)$, polystyrene $(8 \%)$, and other $(13 \%)$.

2. Magazines (4.7\%), phone book (12.5\%), envelopes (12.9\%), letterhead (15.7\%), notebook paper (15.7\%), yellow legal paper (15.7\%), sticky notes (15.7\%), and glossy paper $(7.4 \%)$. 


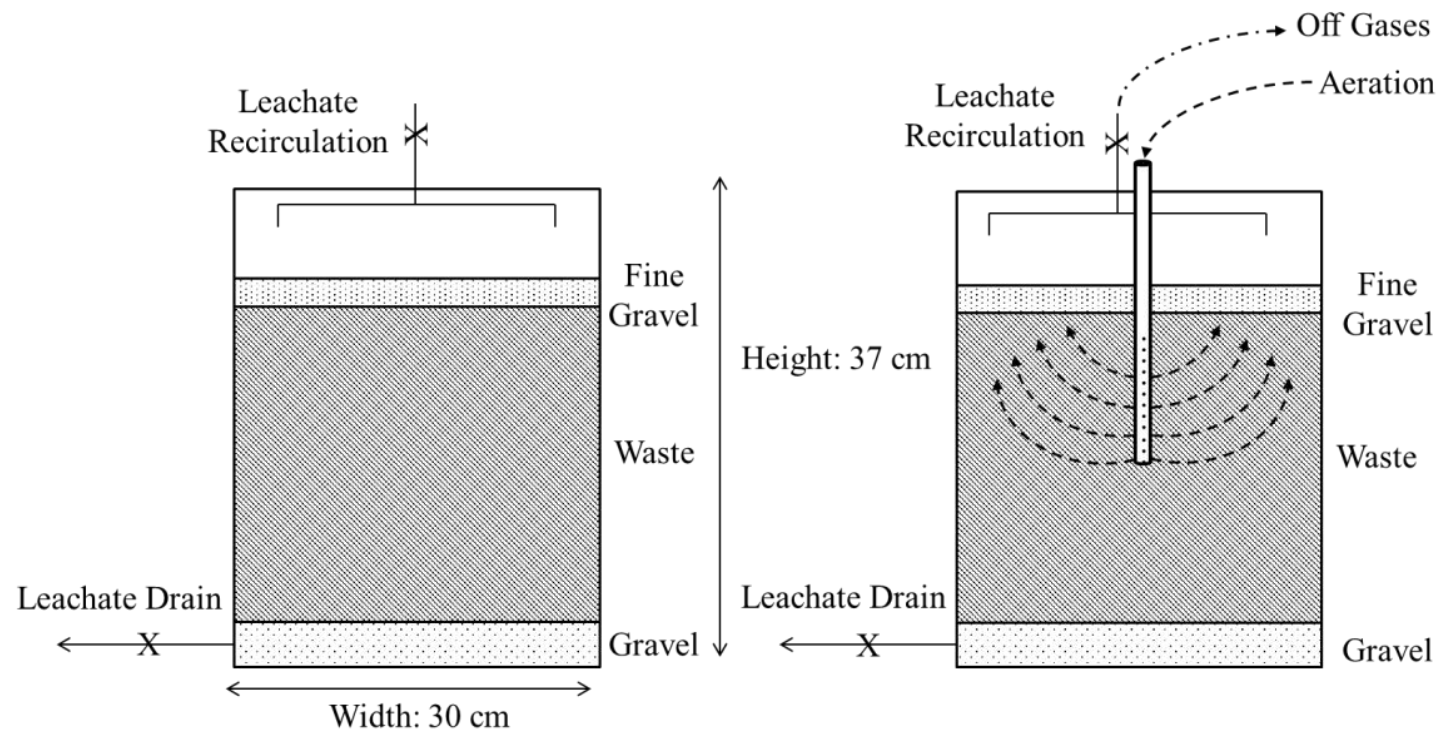

Figure D-1. Design that Represents the Three Flushing Bioreactor Scenarios (A) FBs 1 and 2 (B) Pilot Scale STABL (FB 3) 
Table D-2. Summary of Liquid Addition for Flushing Bioreactors 1-3

\begin{tabular}{|c|c|c|c|c|c|c|}
\hline Date & $\begin{array}{c}\text { Total } \\
\text { Leachate } \\
\text { Collected } \\
(\mathrm{mL})\end{array}$ & $\begin{array}{c}\text { Total DI } \\
\text { Water Added } \\
(\mathrm{mL})\end{array}$ & $\begin{array}{c}\text { Total Leachate } \\
\text { Removed for } \\
\text { Sampling } \\
(\mathrm{mL})\end{array}$ & $\begin{array}{c}\text { Loss Through } \\
\text { Fenton's } \\
\text { Treatment }(\mathrm{mL})\end{array}$ & $\begin{array}{c}\text { Total Loss } \\
\text { (Fenton }+ \\
\text { Sampling) } \\
(\mathrm{mL})\end{array}$ & $\begin{array}{c}\text { Total DI } \\
\text { Water' }{ }^{1} \\
\text { Leachate } \\
\text { Recirculated } \\
(\mathrm{mL})\end{array}$ \\
\hline FB 1A & 5435 & 5646 & 5478 & 0 & 5478 & $5316^{1}$ \\
\hline FB 1B & 14690 & 16866 & 15016 & 0 & 15016 & $16866^{1}$ \\
\hline FB 1C & 9510 & 16206 & 9801 & 0 & 9801 & $16536^{1}$ \\
\hline FB 1D & 15920 & 16866 & 16096 & 0 & 16096 & $16866^{1}$ \\
\hline FB 1E & 5600 & 5646 & 5896 & 0 & 5896 & $5316^{1}$ \\
\hline FB 1F & 9355 & 16206 & 9681 & 0 & 9681 & $16536^{1}$ \\
\hline FB 2A & 5440 & 963 & 410 & 1080 & 1490 & 5544 \\
\hline FB 2B & 5790 & 793 & 390 & 1180 & 1570 & 5626 \\
\hline FB 2C & 10350 & 1156 & 480 & 1110 & 1590 & 10231 \\
\hline FB 2D & 10335 & 1005 & 490 & 1035 & 1525 & 10208 \\
\hline FB 2E & 16570 & 1446 & 545 & 1175 & 1720 & 16946 \\
\hline FB 2F & 16680 & 1286 & 540 & 1150 & 1690 & 16606 \\
\hline FB 3A & 9650 & 6357 & 390 & 1050 & 1440 & 15196 \\
\hline FB 3B & 9110 & 6702 & 440 & 1020 & 1460 & 15146 \\
\hline FB 3C & 4020 & 1852 & 275 & 855 & 1130 & 5346 \\
\hline FB 3D & 5660 & 3827 & 310 & 690 & 1000 & 9046 \\
\hline FB 3E & 3610 & 2227 & 220 & 780 & 1000 & 5186 \\
\hline FB 3F & 6235 & 3457 & 290 & 825 & 1115 & 9046 \\
\hline 1. & Dan & & & & \\
\hline
\end{tabular}

1. DI water added to FBs. 


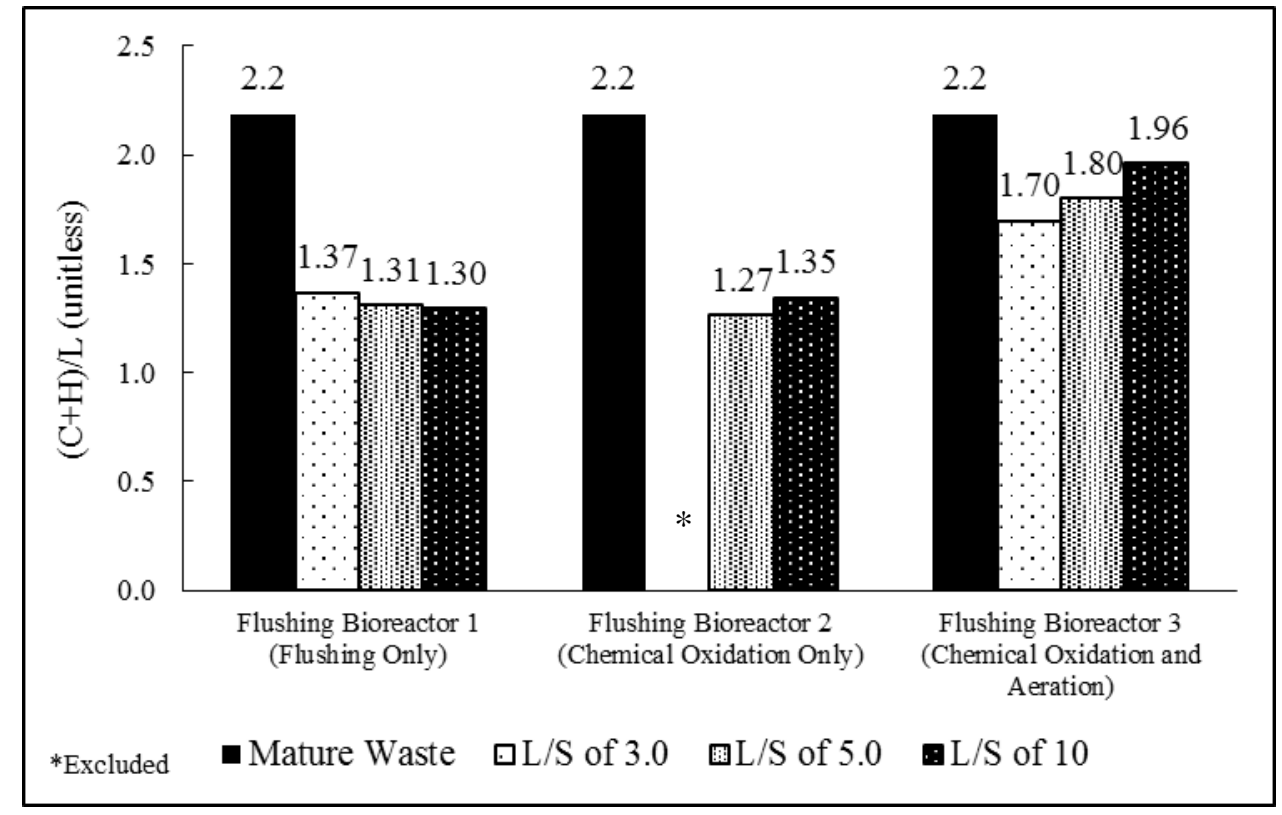

Figure D-2. Cellulose plus Hemicellulose to Lignin Ratio of Waste Removed from Flushing Bioreactors

Table D-3. Characteristics of the Mature Leachate used to Initiate Flushing in FBs 2 and 3

\begin{tabular}{|c|c|}
\hline Parameter & Value \\
\hline $\mathrm{pH}(\mathrm{S} . \mathrm{U})$. & 7.6 \\
\hline $\mathrm{COD}(\mathrm{mg} / \mathrm{L})$ & 5350 \\
\hline $\mathrm{BOD}_{5}(\mathrm{mg} / \mathrm{L})$ & 161 \\
\hline $\mathrm{BOD}_{5} / \mathrm{COD}(\mathrm{mg} / \mathrm{L})$ & 0.03 \\
\hline $\mathrm{NH}_{3}-\mathrm{N}(\mathrm{mg} / \mathrm{L})$ & 472 \\
\hline Humic Acid $(\mathrm{mg} / \mathrm{L})$ & 1200 \\
\hline
\end{tabular}


Table D-4. Characteristics of Anaerobic and Flushing Bioreactors Waste

\begin{tabular}{|c|c|c|c|c|c|c|c|c|c|c|c|c|c|}
\hline & $\mathrm{L} / \mathrm{S}$ & $\begin{array}{l}\text { Moisture Content } \\
\text { (\% by weight) }\end{array}$ & $\begin{array}{c}\text { Biodegradable } \\
\text { Solids } \\
\text { (\% by weight) }\end{array}$ & $\begin{array}{c}\text { Cellulose }^{1} \\
(\%)\end{array}$ & $\begin{array}{l}\text { Hemicellulose }^{2} \\
(\%)\end{array}$ & $\begin{array}{l}\operatorname{Lignin}^{3} \\
(\%)\end{array}$ & $\begin{array}{c}\text { Carbon }^{4} \\
(\%)\end{array}$ & $\begin{array}{l}\text { Nitrogen }^{5} \\
(\%)\end{array}$ & $\mathrm{C} / \mathrm{N}$ & $(\mathrm{C}+\mathrm{H}) / \mathrm{L}$ & $\mathrm{C} / \mathrm{L}$ & $\begin{array}{l}\text { Organic Carbon } \\
\text { (\% by weight) }\end{array}$ & $\begin{array}{c}\mathrm{BMP}\left(\mathrm{m}^{3} / \mathrm{Mg} \text { of }\right. \\
\text { dry waste })\end{array}$ \\
\hline Initial Waste & - & $46 \%$ & $65 \%$ & 47.8 & 12.6 & 12.6 & 38.78 & 0.29 & 136 & 4.8 & 3.8 & $78 \%$ & 140 \\
\hline Mature Waste & - & $61 \%$ & $31 \%$ & 29.5 & 9.8 & 25.1 & 33.61 & 0.79 & 39 & 2.2 & 1.2 & $36 \%$ & 47 \\
\hline \multirow{3}{*}{ FB 1} & 3 & $61 \%$ & $29 \%$ & 8.2 & 4.4 & 18.9 & 23.72 & 0.98 & 27 & 1.4 & 0.44 & $19 \%$ & 17 \\
\hline & 5 & $63 \%$ & $23 \%$ & 6.29 & 4.22 & 20.63 & 16.96 & 0.64 & 26 & 1.3 & 0.31 & $18 \%$ & 9 \\
\hline & 10 & $63 \%$ & $24 \%$ & 6.4 & 3.5 & 19.4 & 16.38 & 0.68 & 24 & 1.3 & 0.33 & $18 \%$ & 10 \\
\hline \multirow{3}{*}{ FB 2} & 3 & $54 \%$ & $27 \%$ & 33.9 & 11 & 22.2 & 32.96 & 0.73 & $45^{6}$ & $2.02^{6}$ & $1.53^{6}$ & $18 \%$ & 42 \\
\hline & 5 & $61 \%$ & $26 \%$ & 8.5 & 5.3 & 24.36 & 22.80 & 0.80 & 27 & 1.3 & 0.35 & $20 \%$ & 14 \\
\hline & 10 & $62 \%$ & $25 \%$ & 10.9 & 5.3 & 23.2 & 25.81 & 0.89 & 29 & 1.3 & 0.47 & $16 \%$ & 20 \\
\hline \multirow{3}{*}{ FB 3} & 3 & $46 \%$ & $28 \%$ & 13.9 & 5.2 & 16.7 & 25.77 & 0.74 & 34 & 1.7 & 0.74 & $25 \%$ & 36 \\
\hline & 5 & $41 \%$ & $28 \%$ & 18.5 & 7.9 & 22.6 & 20.86 & 0.71 & 30 & 1.8 & 0.82 & $23 \%$ & 28 \\
\hline & 10 & $37 \%$ & $28 \%$ & 5.8 & 2.8 & 9.25 & 17.44 & 0.63 & 28 & 2 & 0.62 & $19 \%$ & 31 \\
\hline
\end{tabular}

1. $\mathrm{g}$ cellulose/g dry wt. of biodegradable fraction

2. $\mathrm{g}$ hemicellulose/g dry wt. of biodegradable fraction

3. g lignin/g dry wt. of biodegradable fraction

4. g carbon/g dry wt. of biodegradable fraction

5. g nitrogen/g dry wt. of biodegradable fraction

6. A statistical analysis did not support that these data points were significant outlier $(\mathrm{P}>0.05)$ but do not reflect the extent of degradation that should have occurred relative to the mature waste. 


\section{Cost Analysis}

The cost of Fenton's Reagent treatment $(\$ / \mathrm{L})$ was determined using Equation 1, which was adapted from Batarseh et al.(Batarseh et al., 2007) This equation takes into account the aforementioned Fenton's Reagent dosage ( 0.4 molar ratio of Fe to $\mathrm{H}_{2} \mathrm{O}_{2}$ and $1 \mathrm{~g} \mathrm{H}_{2} \mathrm{O}_{2}: 1 \mathrm{~g} \mathrm{COD}$ ), leachate volume, COD concentration, air addition, and Fenton's solids disposal, where applicable.

$$
C\left(\frac{\$}{L}\right)=\left\{\left[\mathrm{COD}_{C}\right]\left(\frac{\left[\mathrm{H}_{2} \mathrm{O}_{2}\right]}{\left[\mathrm{COD}_{c}\right]} \times \frac{\$}{\text { mole } \mathrm{H}_{2} \mathrm{O}_{2}}+\frac{\left[\mathrm{Fe}^{2+}\right]}{\left[\mathrm{COD}_{c}\right]} \times \frac{\$}{\text { mole } \mathrm{Fe}^{2+}}\right)\right\}+Z+\mathrm{FS}_{\text {wet }}
$$

Where:

$\mathrm{COD}_{\mathrm{c}}=$ the concentration of COD expressed as mg-C/L

$\left[\mathrm{H}_{2} \mathrm{O}_{2}\right] /\left[\mathrm{COD}_{\mathrm{c}}\right]=0.94($ Batarseh et al., 2007)

$\left[\mathrm{Fe}^{2+}\right] /\left[\mathrm{COD}_{\mathrm{c}}\right]=0.38$ (Batarseh et al., 2007)

$\mathrm{Z}=$ capital costs, construction, and electricity

$\mathrm{FS}_{\mathrm{wet}}=$ Cost of Fenton's solids disposal (wet; assuming 2\% solids)

The average costs of hydrogen peroxide ( $50 \%$ by volume), ferrous chloride, electricity, potable water, and leachate treatment were determined from published literature values and municipal utility rates.(Batarseh et al., 2007; Berge et al., 2006; Chemical, 2014; Chemicals, 2014; County, 2014; Energy, 2014; Water, 2014) The costs of Fenton's Reagent infrastructure, electricity, and miscellaneous chemicals for $\mathrm{pH}$ adjustment are based on a pilot plant project published by Choi(Choi, 1998) and converted to present day cost using an inflation of $3 \%$ ( $\mathrm{Z}$ is equal to $\$ 0.0845 / \mathrm{L})$. The pilot plant included mixing, oxidation, neutralization and settling tanks. Additional tanks were also included for $\mathrm{H}_{2} \mathrm{O}_{2}$, ferrous chloride, $\mathrm{HCl}$, and $\mathrm{NaOH}$ storage. Costs 
associated with leachate treatment were approximately $\$ 0.017 / \mathrm{L}$ assuming direct discharge to a sewer system(County, 2014; Water, 2014) and potable water usage was $\$ 0.0013 / \mathrm{L}$ determine from published municipality rates.(Berge et al., 2006; Cardinal Engineering, 2000; Willmar, 2012; Wyoming, 2014) The disposal method for the Fenton's Reagent solids (2\% solids) was assumed to be landfilling. The cost of disposal ( $\left.\mathrm{FS}_{\text {wet }}\right)$ was approximately $\$ 0.011 / \mathrm{L}$ and $\$ 0.014 / \mathrm{L}$ of leachate treated for FBs 2 and 3, respectively (\$33.06/tonne(Commissioners, 2013)). The cost of aeration was approximately $\$ 2.08$ per tonne of landfilled waste and was calculated based on values reported by Heyer et al.(Heyer et al., 2005)

Estimated costs of each FB scenario for L/S of 3, 5, and 10 are shown in Figures C-3 and C4. Cost estimated in this paper do not include the infrastructure for leachate recirculation or air injection, where applicable. It is assumed that air injection was included during the design and construction of the landfill and that these costs were incurred prior to closure.(Berge et al., 2006) If this infrastructure was not included in the initial design and was built as a retrofit, the cost of leachate recirculation and air injection (blowers, piping, and valves) is estimated to be approximately $\$ 96,000$ and $\$ 81,000$, respectively.(Berge et al., 2006) There were significant differences in treatment costs for the FB scenarios. Leachate treatment was the major driver for these cost differences. Solid waste and leachate data support that flushing in FB 1 was an efficient method to remove pollutants but at a substantially higher cost due to the required water addition and associated leachate treatment. FBs 2 and 3 had significantly lower costs due to onsite and in-situ treatment of leachate. FB 3 costs were lower than FB 2 due to the evaporation of leachate during aeration, which reduces the total volume requiring treatment by Fenton's Regent.

To compare the effectiveness of each FB scenario, the cost relative to the percent carbon or nitrogen removed was considered. As shown in Figures C-3 and C-4, the cost increases with 
increasing mass of carbon and nitrogen removal. The maximum extent of treatment that could be achieved was assumed to occur by L/S of 10 because there were minimal changes in the solid waste characteristics and leachate quality between L/S of 5 and 10. If a landfill is capped after closure and there is no leachate recirculation or liquid addition then it would not be possible to reach L/S of 10 (i.e., point of completion) during the thirty-year PCC period. Therefore the PCC period may be extended (i.e., perpetual care) and would translate to additional expenses for a landfill that may not have been anticipated. The FB scenarios have the potential to end or reduce PCC, which would subsequently offset the additional costs associated with leachate recirculation and treatment. An analysis of the site specific L/S would need to be completed to determine the time required to reach L/S of 10. After this information is determined then a cost comparison of FBs 1-3 can be completed relative to the percent carbon or nitrogen removed (estimated using Figures C-3 and C-4) and further compared to the traditional method of capping (i.e., dry entombment).

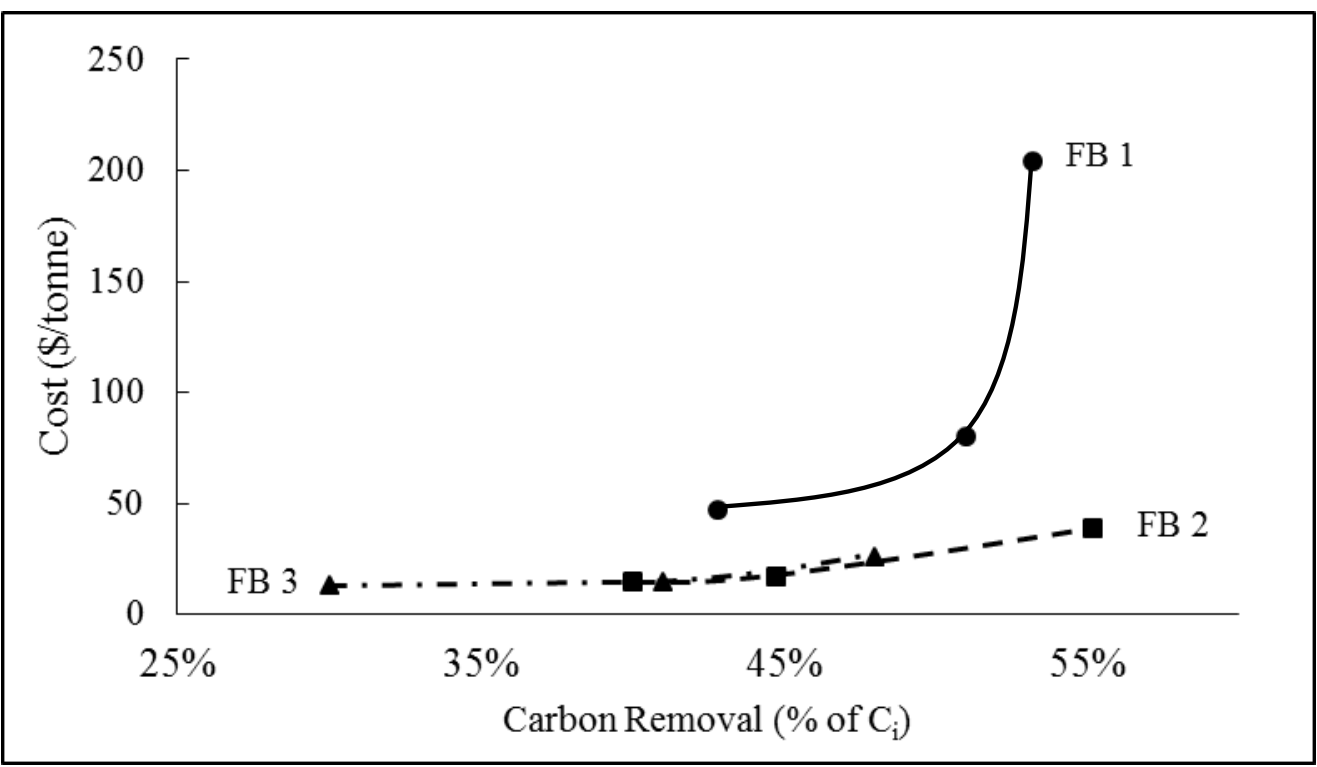

Figure D-3. Cost of Treatment based on the Mass of Carbon Removed from Waste 


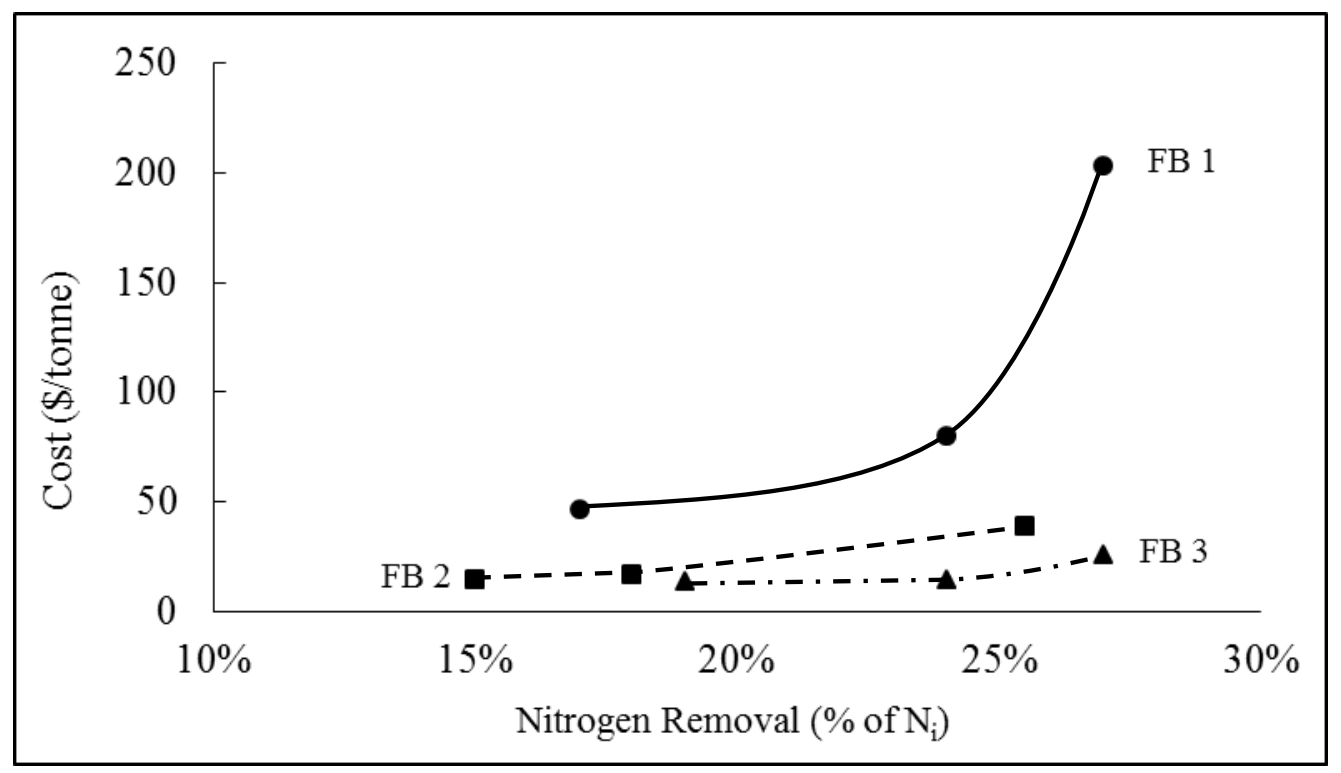

Figure D-4. Cost of Treatment based on the Mass of Nitrogen Removed from Waste 


\section{References}

Batarseh, Reinhart, D., \& Daly, L. (2007). Liquid Sodium Ferrate and Fenton's Reagent for Treatment of Mature Landfill Leachate. Journal of Environmental Engineering, 133(11), 1042-1050. doi: doi:10.1061/(ASCE)0733-9372(2007)133:11(1042)

Berge, N. D., Reinhart, D. R., Dietz, J., \& Townsend, T. (2006). In situ ammonia removal in bioreactor landfill leachate. Waste Management, 26(4), 334-343. doi: http://dx.doi.org/10.1016/j.wasman.2005.11.003

Cardinal Engineering, I. (2000). Oklahoma Department of Environmental Quality: Solid Waste Financial Assurance Program Report.

Chemical, I. (2014). Hydrogen Peroxide (50\%). from http://www.integrachem.com/pdfs/integrachemicalcatalog.pdf

Chemicals, G. (2014). Ferrous Chloride Tetrahyrdrate Reagent. from http://gfschemicals.rtrk.com

Choi, H. (1998). Evaluation of Fenton's Process For the Treatment of Landfill Leachate. (PhD), University of Delaware.

Commissioners, O. C. B. o. (2013). Orange County Board of Commissioners Fee Schedule: Fiscal Year 2013-2014. from http://www.orangecountyfl.net/Portals/0/Library/Open\%20Government/docs/FeeDirector y.pdf

County, P. (2014). Polk County Utility Rate and Fees.

Energy, U. S. D. o. (2014). U.S. Energy Information Administration - EIA - Independent Statistics and Analysis, Average Retail Price of Electricity to Ultimate Customers by End-Use Sector, 2014.

Heyer, K. U., Hupe, K., Ritzkowski, M., \& Stegmann, R. (2005). Pollutant release and pollutant reduction - Impact of the aeration of landfills. Waste Management, 25(4), 353-359. doi: http://dx.doi.org/10.1016/j.wasman.2005.02.007

Water, P. A. (2014). Pennsylvania American Water Rates Information. from http://www.amwater.com/paaw/customer-service/rates-information.html

Willmar, C. o. (2012). City of Willmar Leachate Agreement. from http://www.co.kandiyohi.mn.us/docs/Board/Agenda/BoardPacket/Leachate_Agreement.p df

Wyoming, C. o. (2014). City of Wyoming Fee Schedules: Water and Wastewater Service Charges. from http://wyomingmi.gov/ForBusinesses/fee-schedules.asp 


\section{APPENDIX E}

SUPPLEMENTAL INFORMATION: CONVENTIONAL AND FOURIER TRANSFORM INFRARED CHARACTERIZATION OF WASTE DURING MUNICIPAL SOLID WASTE STABILIZATION 


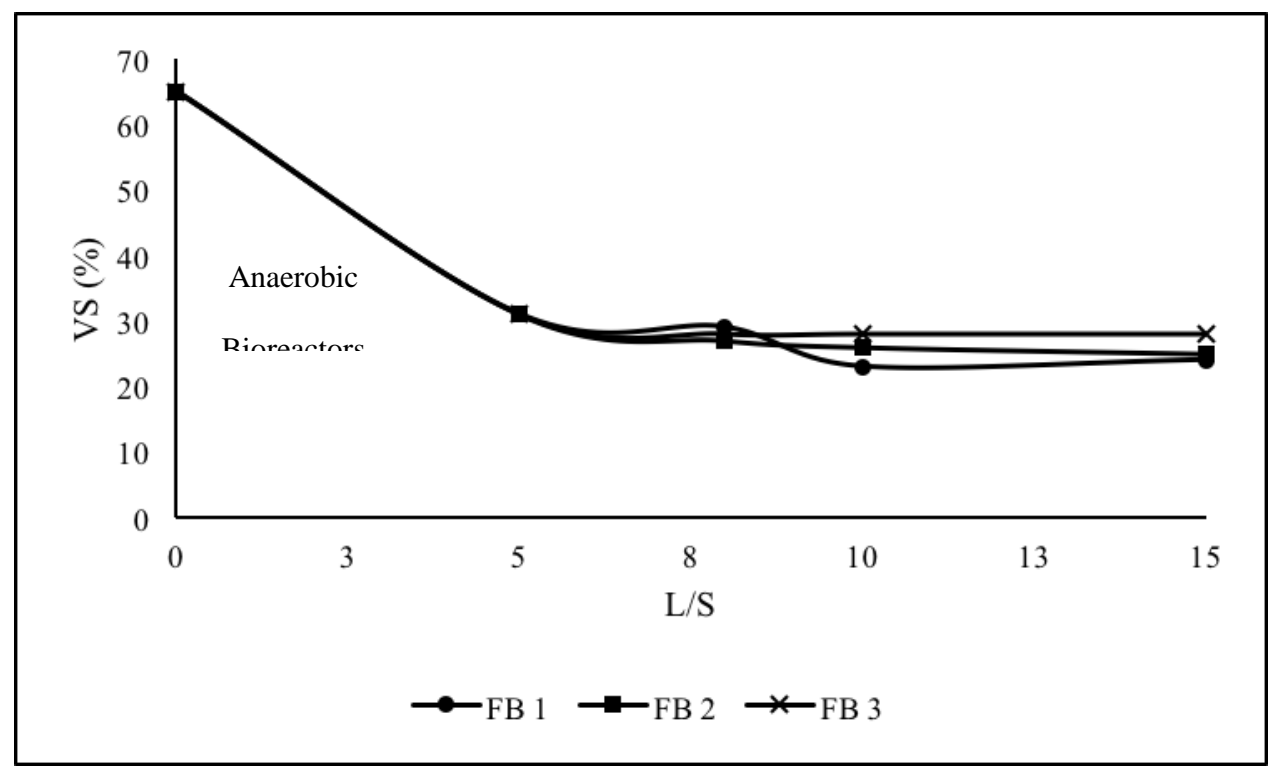

Figure E-1. Volatile Solids Flushing Bioreactors 1-3

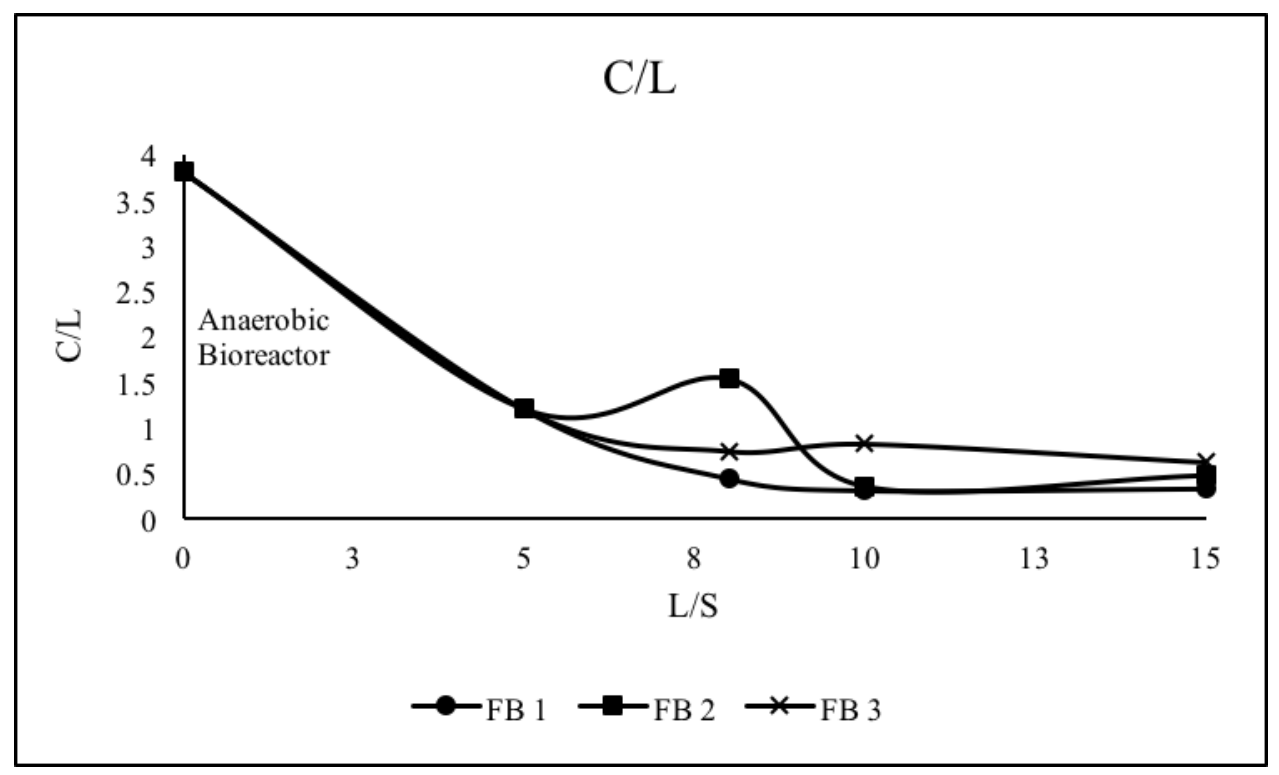

Figure E-2. Cellulose/Lignin Ratio Flushing Bioreactors 1-3 


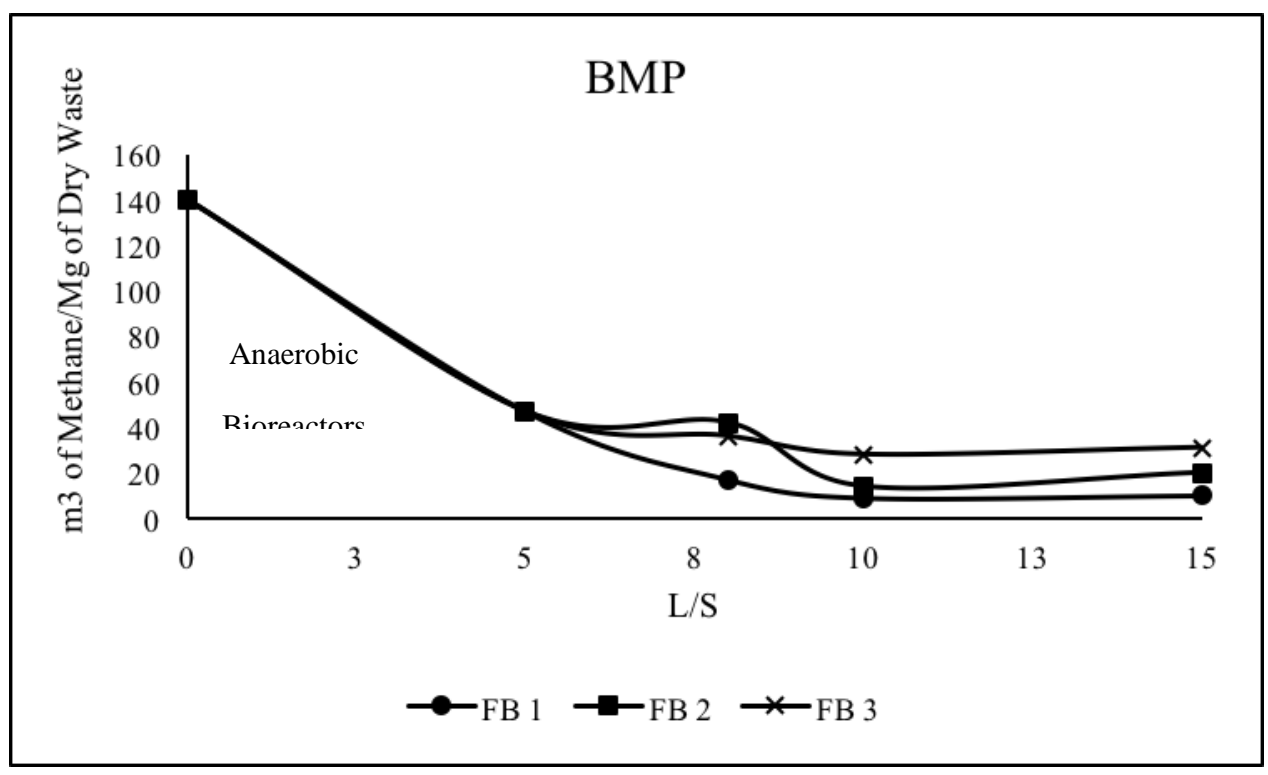

Figure E-3. Biochemical Methane Potential Flushing Bioreactors 1-3

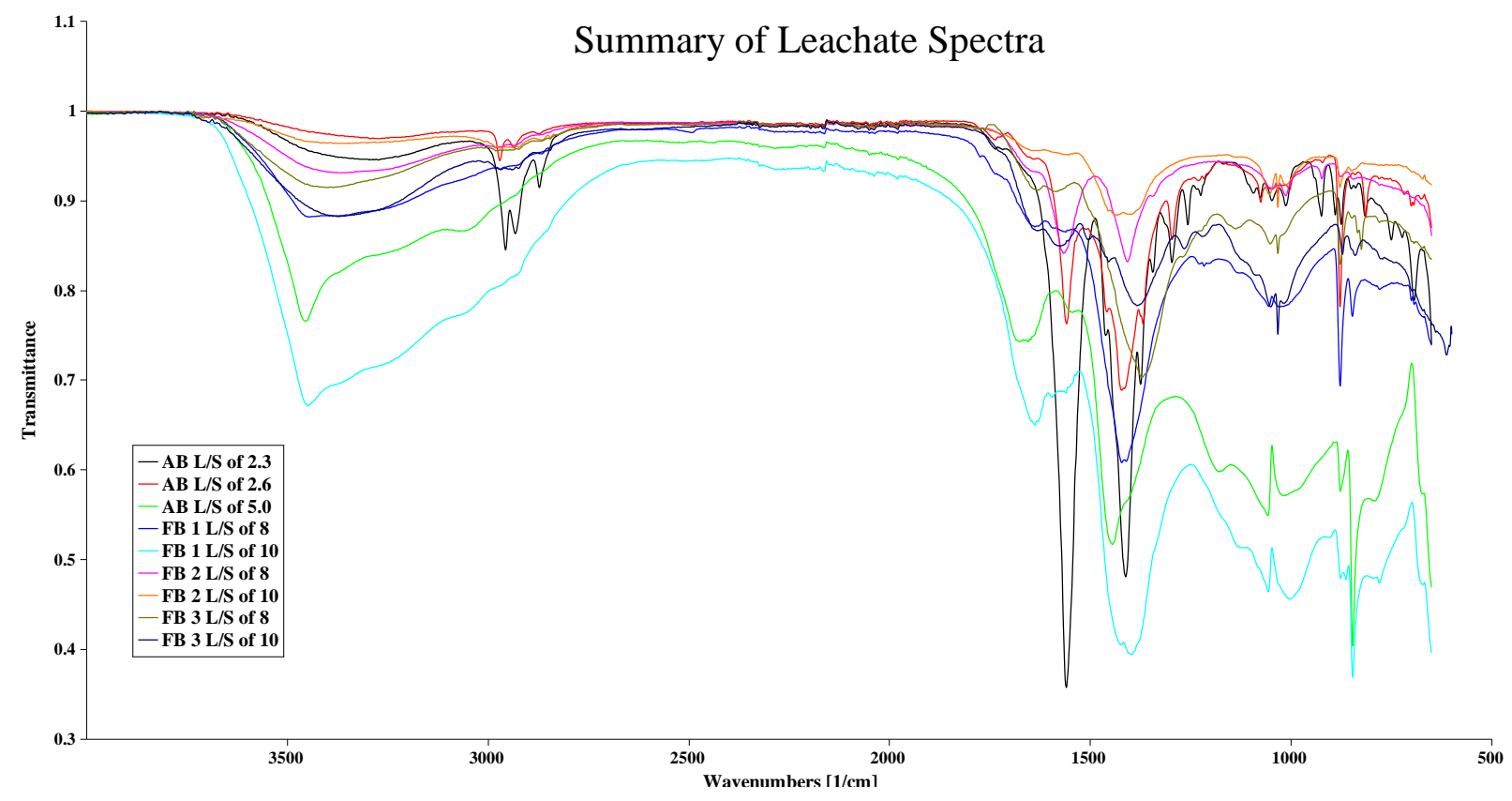

Figure E-4. Spectral Profiles of Anaerobic and Flushing Bioreactors 1-3 Leachates 

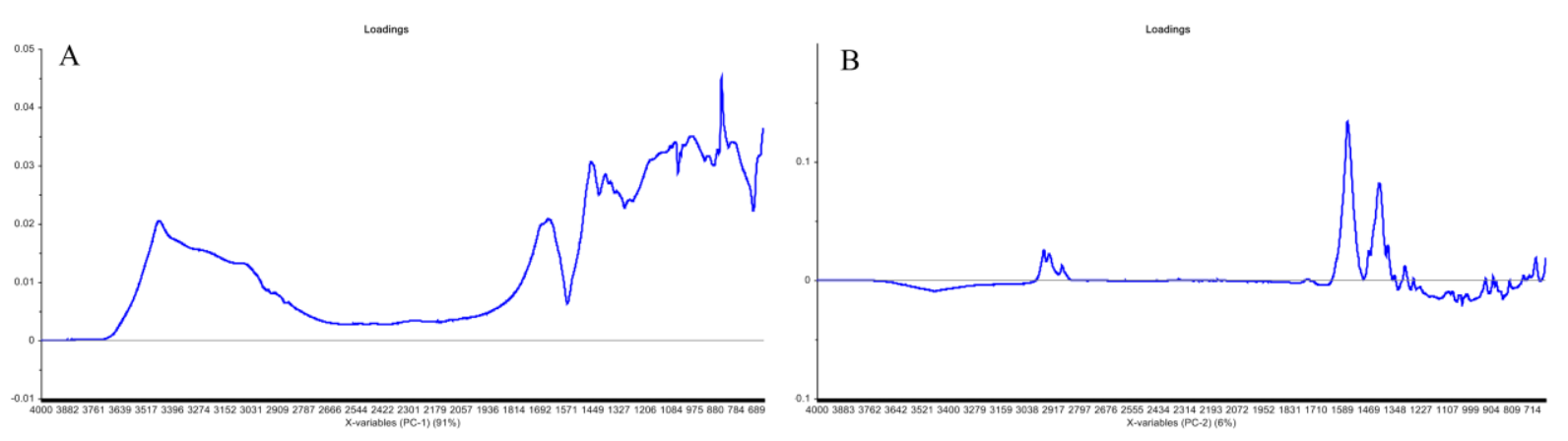

Figure E-5. Loading Plot for Anaerobic Bioreactor and FBs 1-3 (L/S of 8-10) Leachates (A) PC $191 \%$ Variance and (2) PC 2 Variance 6\%
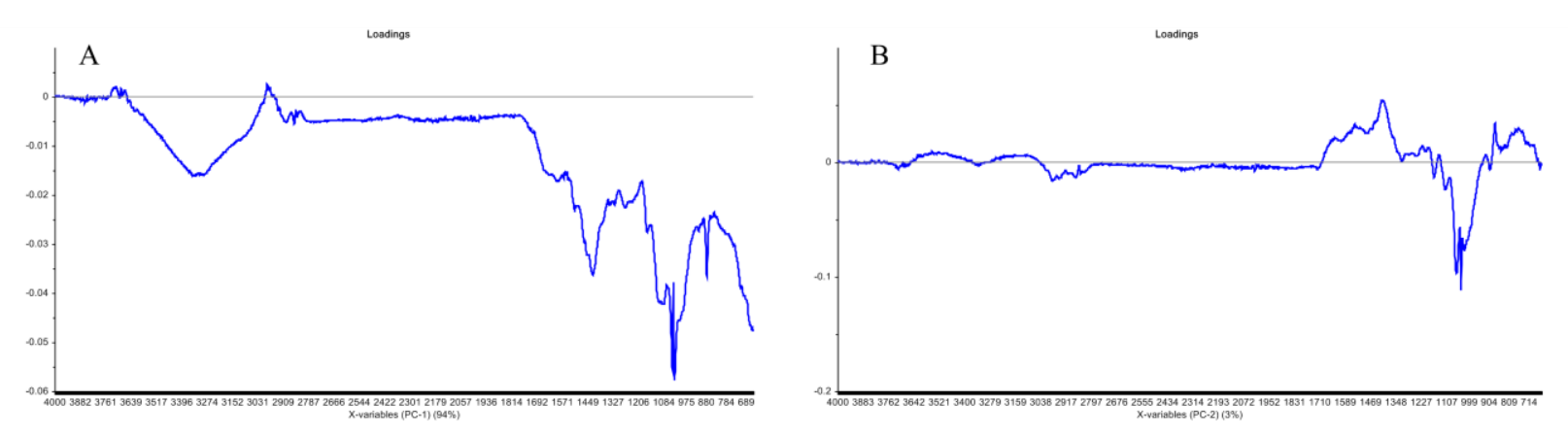

Figure E-6. Loading Plot for Anaerobic Bioreactor and FBs 1-3 (L/S of 8-10) Solid Waste (A) PC $191 \%$ Variance and (2) PC 2 Variance 6\% 


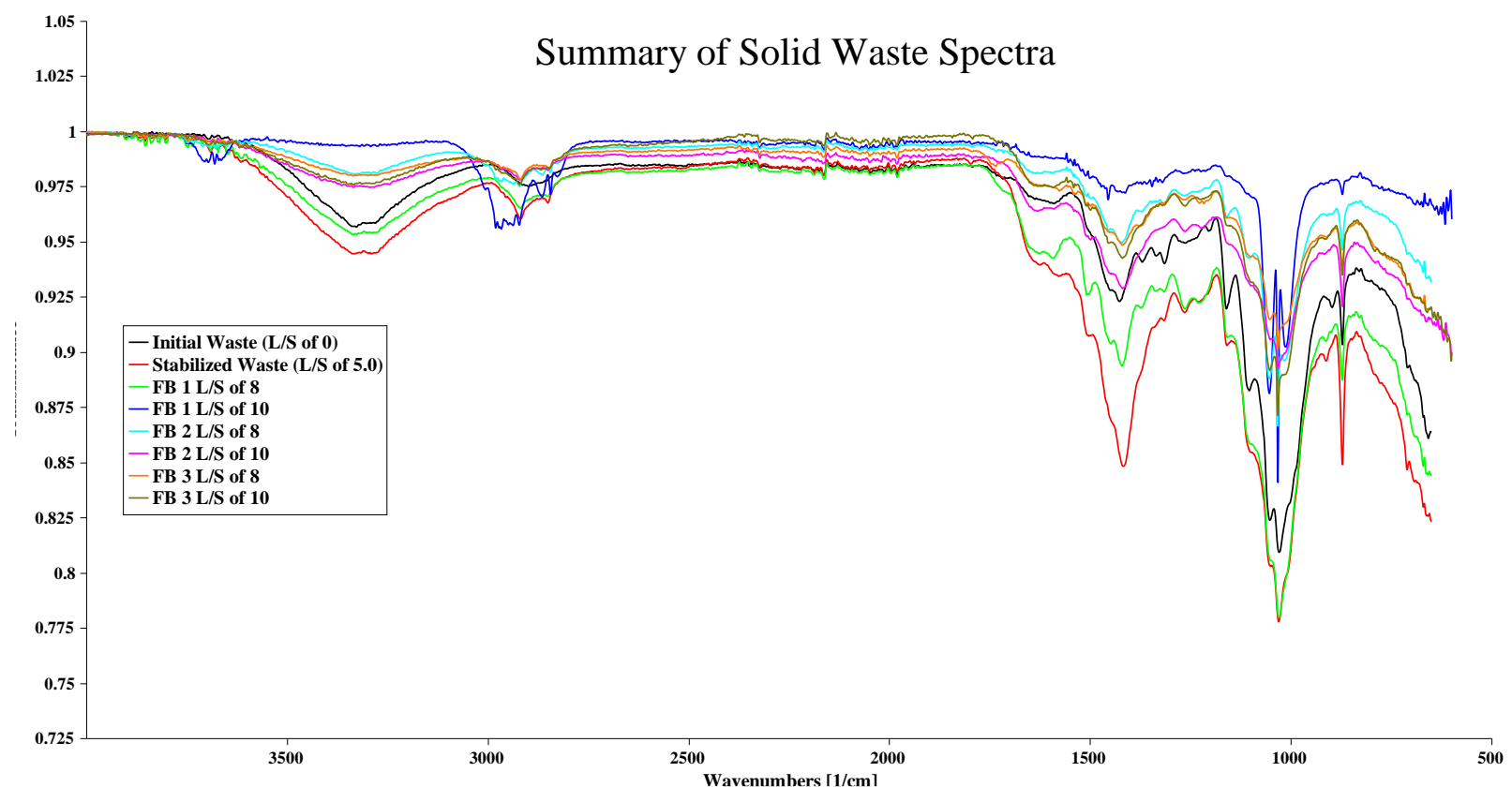

Figure E-7. Spectral Profiles of Anaerobic and Flushing Bioreactors 1-3 Solid Waste 


\section{APPENDIX F}

SUPPLEMENTAL INFORMATION: EVALUATION OF LEACHATE

DISSOLVED ORGANIC NITROGEN DISCHARGE EFFECT ON

WASTEWATER EFFLUENT QUALITY 
Table F-1. Summary of Leachates Characterized

\begin{tabular}{|c|c|c|c|c|c|c|c|c|c|c|c|c|c|}
\hline & Leachate A & Leachate B & Leachate C & Leachate E & Leachate F & Leachate G & Leachate H & Leachate I & Leachate J & Leachate K & Leachate L & Leachate M & Leachate N \\
\hline $\begin{array}{l}\text { Sample } \\
\text { Source }\end{array}$ & $\begin{array}{l}\text { Combined } \\
\text { Leachate }^{1}\end{array}$ & $\begin{array}{l}\text { Leachate } \\
\text { from a } \\
\text { Closed Cell }\end{array}$ & $\begin{array}{l}\text { Combined } \\
\text { Leachate }^{1}\end{array}$ & $\begin{array}{c}\text { Aerated } \\
\text { Leachate } \\
\text { from a } \\
\text { Closed Cell }\end{array}$ & $\begin{array}{l}\text { Combined } \\
\text { Leachate }^{1}\end{array}$ & $\begin{array}{l}\text { Combined } \\
\text { Leachate }^{1}\end{array}$ & $\begin{array}{l}\text { Combined } \\
\text { Leachate }^{1}\end{array}$ & $\begin{array}{l}\text { Combined } \\
\text { Leachate }^{1}\end{array}$ & $\begin{array}{l}\text { Combined } \\
\text { Leachate }\end{array}$ & $\begin{array}{l}\text { Leachate from a } \\
\text { Closed Cell }\end{array}$ & $\begin{array}{l}\text { Leachate from a } \\
\text { Closed Cell }\end{array}$ & $\begin{array}{c}\text { Leachate from } \\
\text { Closed Cell } \\
\text { Stored in an } \\
\text { Open Tank }\end{array}$ & $\begin{array}{l}\text { Leachate from a } \\
\text { Closed Cell }\end{array}$ \\
\hline Total $\mathrm{cBOD}_{5}$ & 326 & 578 & 553 & 121 & 606 & 456 & 150 & 1653 & 80 & 75 & 3730 & 72 & 68 \\
\hline $\begin{array}{c}\text { Total COD } \\
(\mathrm{mg} / \mathrm{L})\end{array}$ & 2625 & 6750 & 3150 & 5050 & 5150 & 4375 & 888 & 6375 & 775 & 1550 & 12275 & 1575 & 1800 \\
\hline $\mathrm{cBOD}_{5} / \mathrm{COD}$ & 0.12 & 0.09 & 0.18 & 0.02 & 0.12 & 0.10 & 0.17 & 0.26 & 0.10 & 0.05 & 0.30 & 0.05 & 0.04 \\
\hline pH (S.U.) & 7.76 & 7.58 & 8.32 & 8.54 & 8.09 & 7.72 & 7.45 & 7.99 & 7.07 & 7.57 & 7.59 & 8.25 & 7.62 \\
\hline $\begin{array}{c}\text { Total NH3-N } \\
(\mathrm{mg} / \mathrm{L})\end{array}$ & 772 & 1708 & 870 & 1713 & 1396 & 276 & 98 & 1980 & 203.5 & 776 & 2300 & 470 & 746 \\
\hline $\begin{array}{c}\text { Total NO3- } \\
\text { NO2 }(\mathrm{mg} / \mathrm{L}) \\
\end{array}$ & 24 & 66 & 15 & 60 & 51 & 35.9 & 7 & 21 & 7 & 27 & 61 & 24 & 25 \\
\hline $\begin{array}{c}\text { Total TKN } \\
(\mathrm{mg} / \mathrm{L})\end{array}$ & 800 & 1870 & 901 & 1794 & 1419 & 903 & 209.5 & 2080 & 218 & 779 & 2360 & 498 & 793 \\
\hline $\begin{array}{c}\text { Total } \\
\text { Nitrogen } \\
(\mathrm{mg} / \mathrm{L}) \\
\end{array}$ & 824 & 1936 & 916 & 1854 & 1470 & 939 & 216 & 2100 & 224.5 & 806 & 2440 & 522 & 818 \\
\hline DON (mg/L) & 22 & 53 & 31 & 97 & 25 & 56 & 15.5 & 90 & 14 & 10 & 60 & 20 & 36 \\
\hline $\mathrm{DOC}(\mathrm{mg} / \mathrm{L})$ & 941 & 2373 & 1030 & 1486 & 1577 & 1387 & 239 & 2012 & 252 & 552 & 4419 & 527 & 604 \\
\hline DOC/DON & 41.8 & 45.2 & 58.7 & 14.7 & 62.9 & 24.8 & 15.4 & 22.4 & 18.0 & 55.2 & 88.4 & 26.3 & 16.8 \\
\hline $\begin{array}{c}\text { SUVA } \\
(\mathrm{L} / \mathrm{mg}-\mathrm{m})\end{array}$ & 4.19 & 4.33 & 2.43 & 4.23 & 4.55 & 3.34 & 3.39 & 3.68 & 2.65 & 3.42 & 4.31 & 3.16 & 2.95 \\
\hline $\begin{array}{c}\text { Dissolved } \\
\text { UV254 }\end{array}$ & 39.5 & 103 & 25 & 63 & 72 & 46.4 & 8.08 & 74 & 7.54 & 18.9 & 189.6 & 16.4 & 18.6 \\
\hline $\begin{array}{c}\begin{array}{c}\text { E4/E6 } \\
\text { (unitless) }\end{array} \\
\text { (ut }\end{array}$ & 4.8 & 6.31 & 5.80 & 5.15 & 4.85 & 4.8 & 3.7 & 6.0 & 3.0 & 8 & 6.3 & 8.2 & 8.125 \\
\hline $\begin{array}{l}\text { Total UV- } \\
245\end{array}$ & 40.7 & 106 & 27 & 70 & 75 & 51.3 & 8.26 & 76 & 6.5 & 19.7 & 190.95 & 18.7 & 20.5 \\
\hline
\end{tabular}

1. Combined Active and Closed Cells 
Table F-2. Summary of bDON and rDON Concentrations and Percent Recovery

\begin{tabular}{|c|c|c|c|}
\hline & bDON $(\mathrm{mg} / \mathrm{L})$ & rDON $(\mathrm{mg} / \mathrm{L})$ & Percent Recovery $(\%)$ \\
\hline Leachate A & 9.38 & 6.25 & 71 \\
\hline Leachate B & 5.39 & 18.1 & 76 \\
\hline Leachate C & 20.0 & 18.3 & 60 \\
\hline Leachate D & 2.02 & 0.435 & 92 \\
\hline Leachate E & 46.3 & 47.7 & 97 \\
\hline Leachate F & 16.7 & 7.87 & 98 \\
\hline Leachate G & 32.7 & 22.0 & 87 \\
\hline Leachate H & 2.71 & 10.83 & 79 \\
\hline Leachate I & 31.1 & 39.9 & 95 \\
\hline Leachate J & 8.75 & 4.51 & 90 \\
\hline Leachate K & 2.00 & 7.00 & 97 \\
\hline Leachate L & 20.5 & 37.7 & $\mathbf{8 7}$ \\
\hline Average & $\mathbf{1 6 . 5}$ & $\mathbf{1 8 . 4}$ & \\
\hline
\end{tabular}


Table F-3. Calculated Pass through of Leachate rDON and DON in Wastewater Effluent

\begin{tabular}{|c|c|c|c|c|}
\hline & \multicolumn{2}{|c|}{ rDON Pass Through (mg/L) } & \multicolumn{2}{c|}{ DON Pass Through $(\mathrm{mg} / \mathrm{L})$} \\
\hline & $10 \%$ & $1 \%$ & $10 \%$ & $1 \%$ \\
\hline Leachate A & 0.625 & 0.0625 & 2.2 & 0.22 \\
\hline Leachate B & 1.81 & 0.181 & 5.25 & 0.525 \\
\hline Leachate C & 1.83 & 0.183 & 3.1 & 0.31 \\
\hline Leachate D & 0.0435 & 0.00435 & 0.266 & 0.0266 \\
\hline Leachate E & 4.77 & 0.477 & 9.71 & 0.971 \\
\hline Leachate F & 0.787 & 0.0787 & 2.51 & 0.251 \\
\hline Leachate G & 2.2 & 0.22 & 5.6 & 0.56 \\
\hline Leachate H & 1.083 & 0.1083 & 1.55 & 0.155 \\
\hline Leachate I & 3.99 & 0.399 & 9 & 0.9 \\
\hline Leachate J & 0.451 & 0.0451 & 1.4 & 0.14 \\
\hline Leachate K & 0.7 & 0.07 & 1 & 0.1 \\
\hline Leachate L & 3.77 & 0.377 & 6 & 0.6 \\
\hline Average & 1.84 & 0.18 & 3.97 & 0.40 \\
\hline Max & 4.77 & 0.477 & 9.71 & 0.971 \\
\hline Min & 0.0435 & 0.00435 & 0.266 & 0.0266 \\
\hline
\end{tabular}

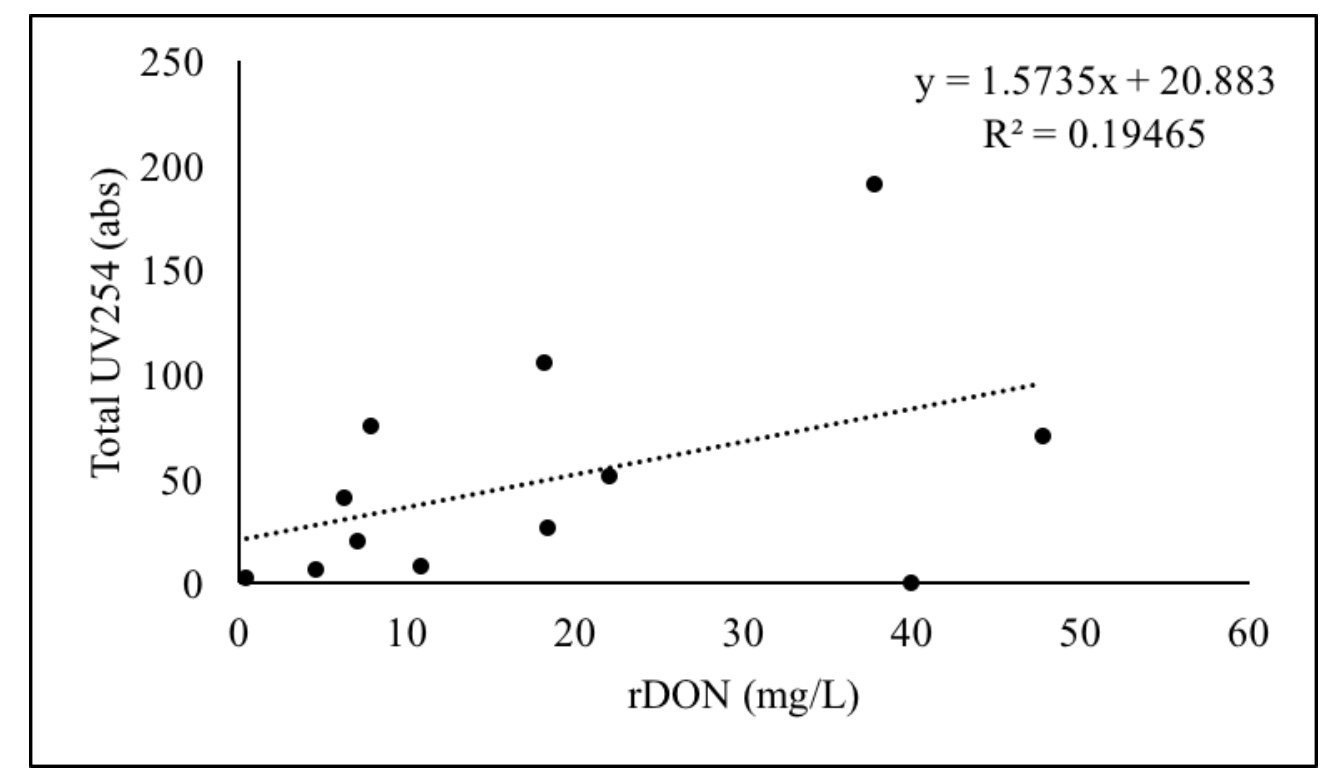

Figure F-1. rDON versus Leachate Total $\mathrm{UV}_{254} \mathrm{~nm}$ Absorbance 


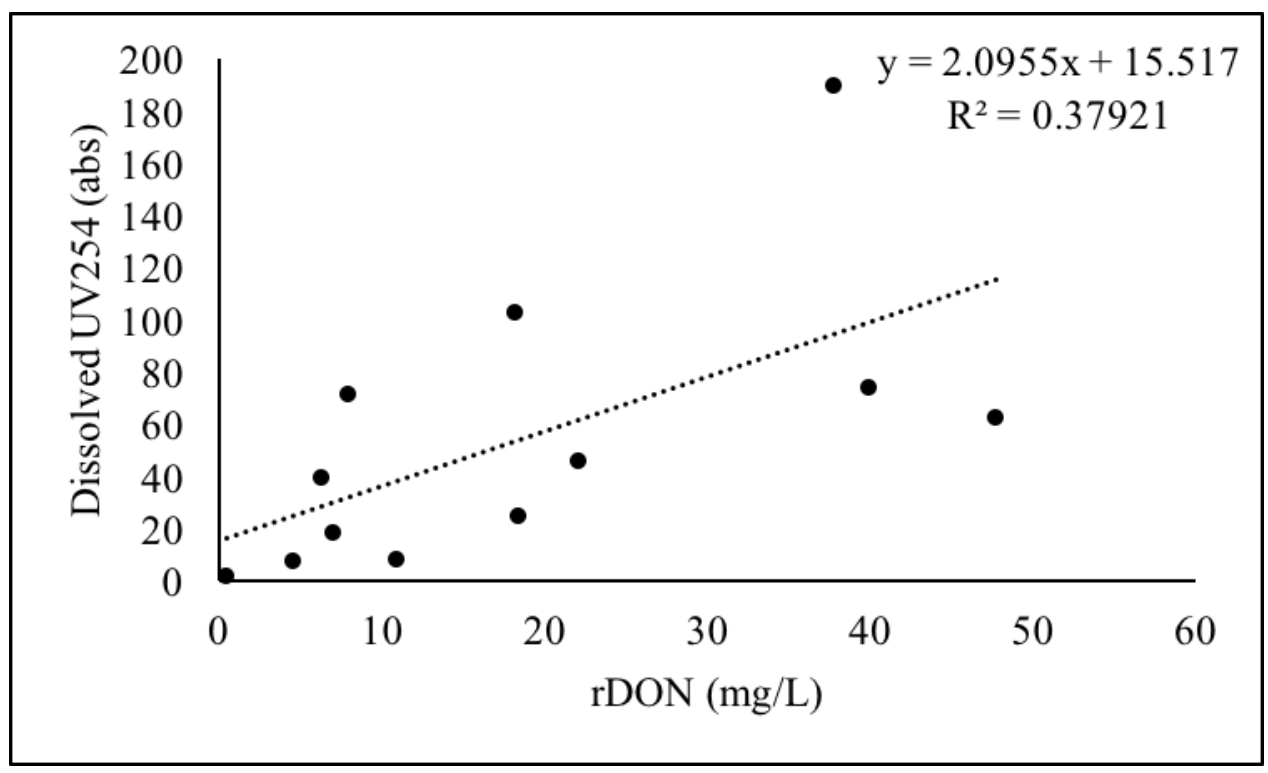

Figure F-2. rDON versus Leachate Dissolved UV 254 nm Absorbance

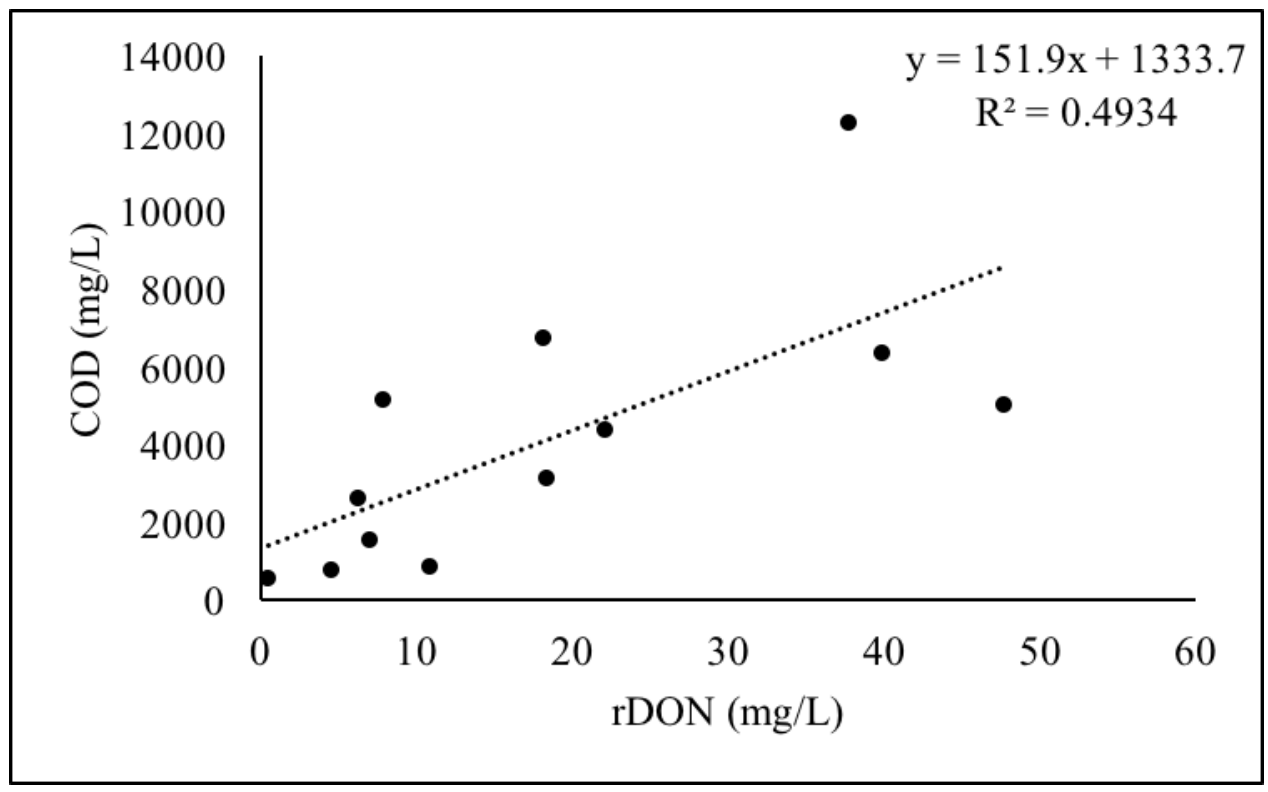

Figure F-3. Figure F-4. rDON versus Leachate Chemical Oxygen Demand 


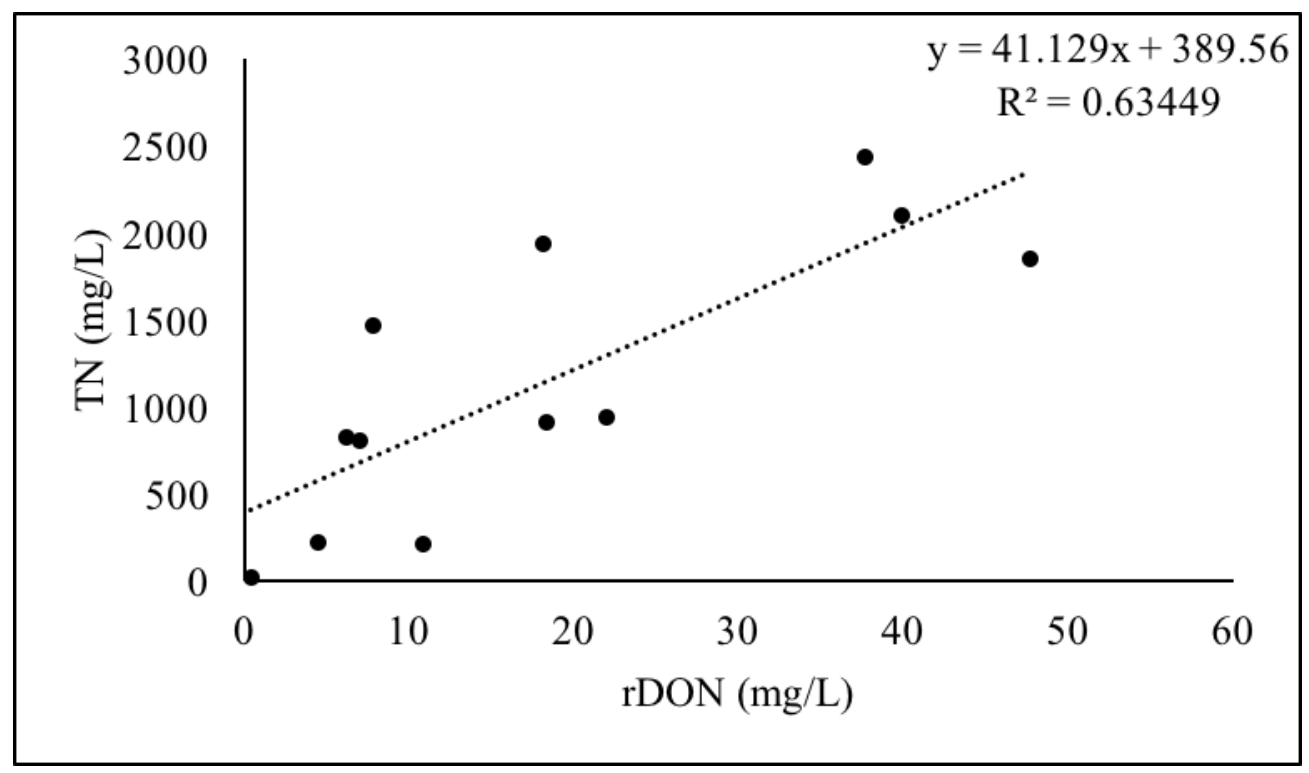

Figure F-5. rDON versus Leachate Total Nitrogen

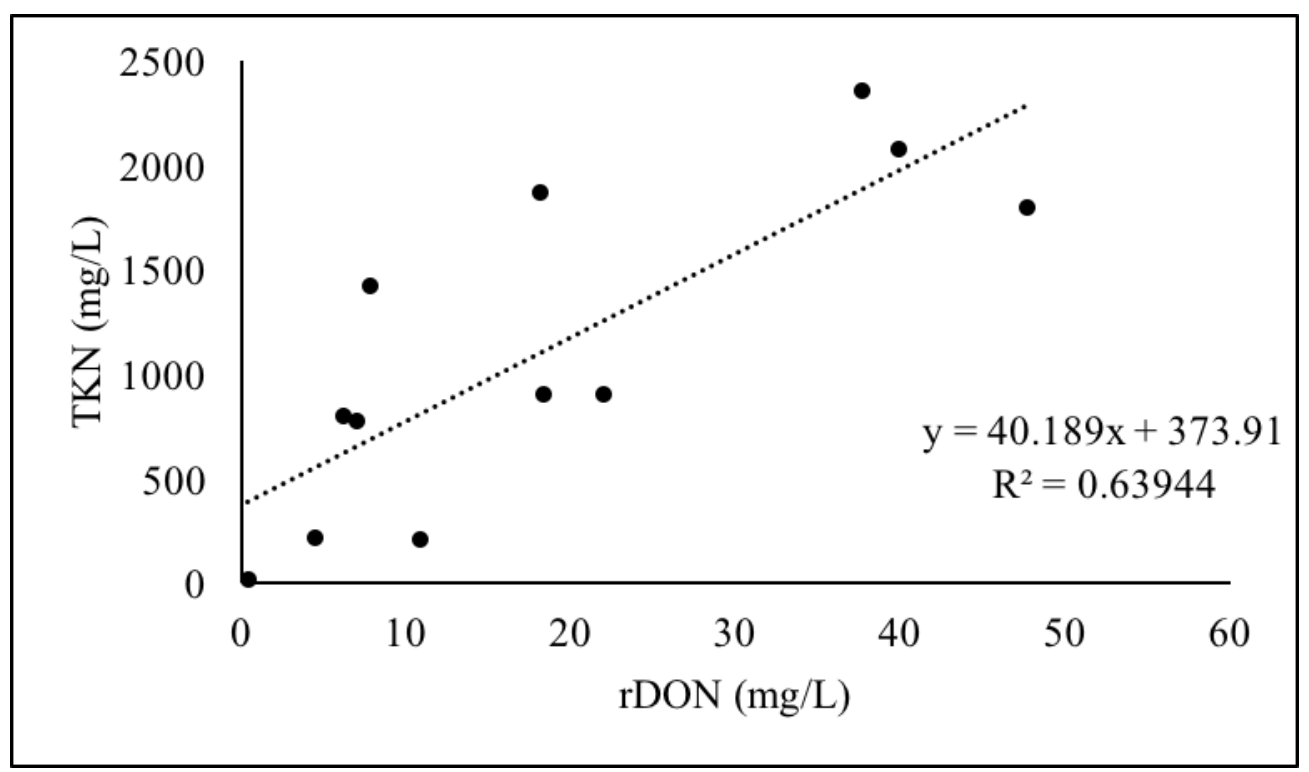

Figure F-6. rDON versus Leachate Total Kjeldahl Nitrogen 


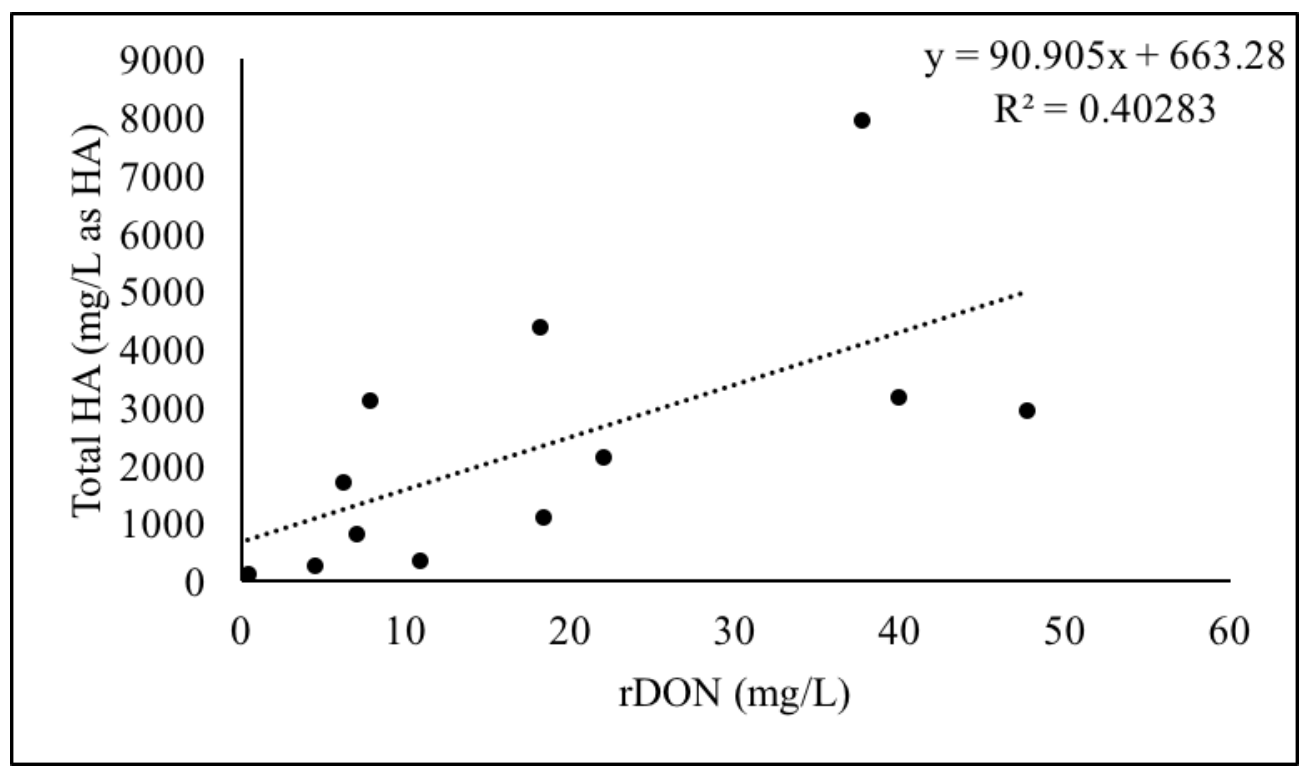

Figure F-7. rDON versus Leachate Total Humic Acid

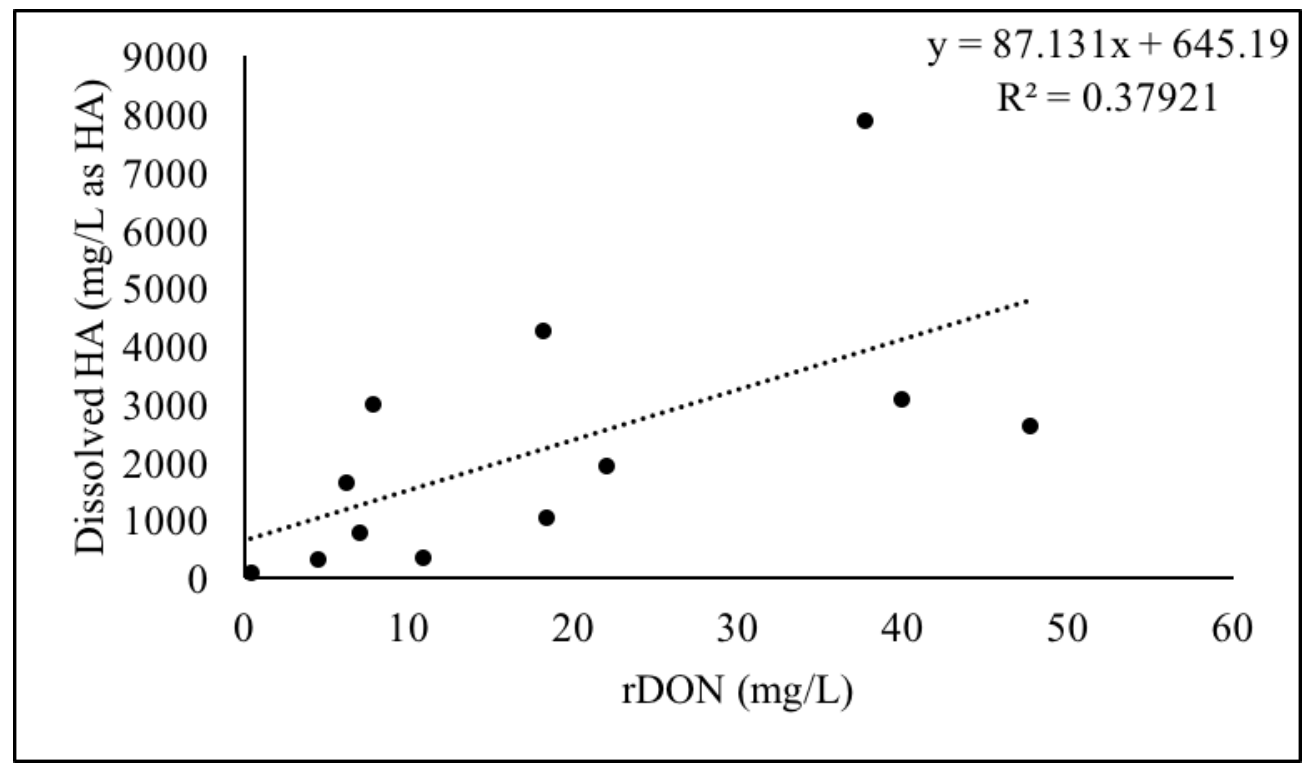

Figure F-8. rDON versus Leachate Dissolved Humic Acid 


\section{APPENDIX G}

SUPPLEMENTAL INFORMATION: FATE OF ORGANIC MATTER

FROM LEACHATE DISCHARGED TO WASTEWATER TREATMENT

PLANTS 


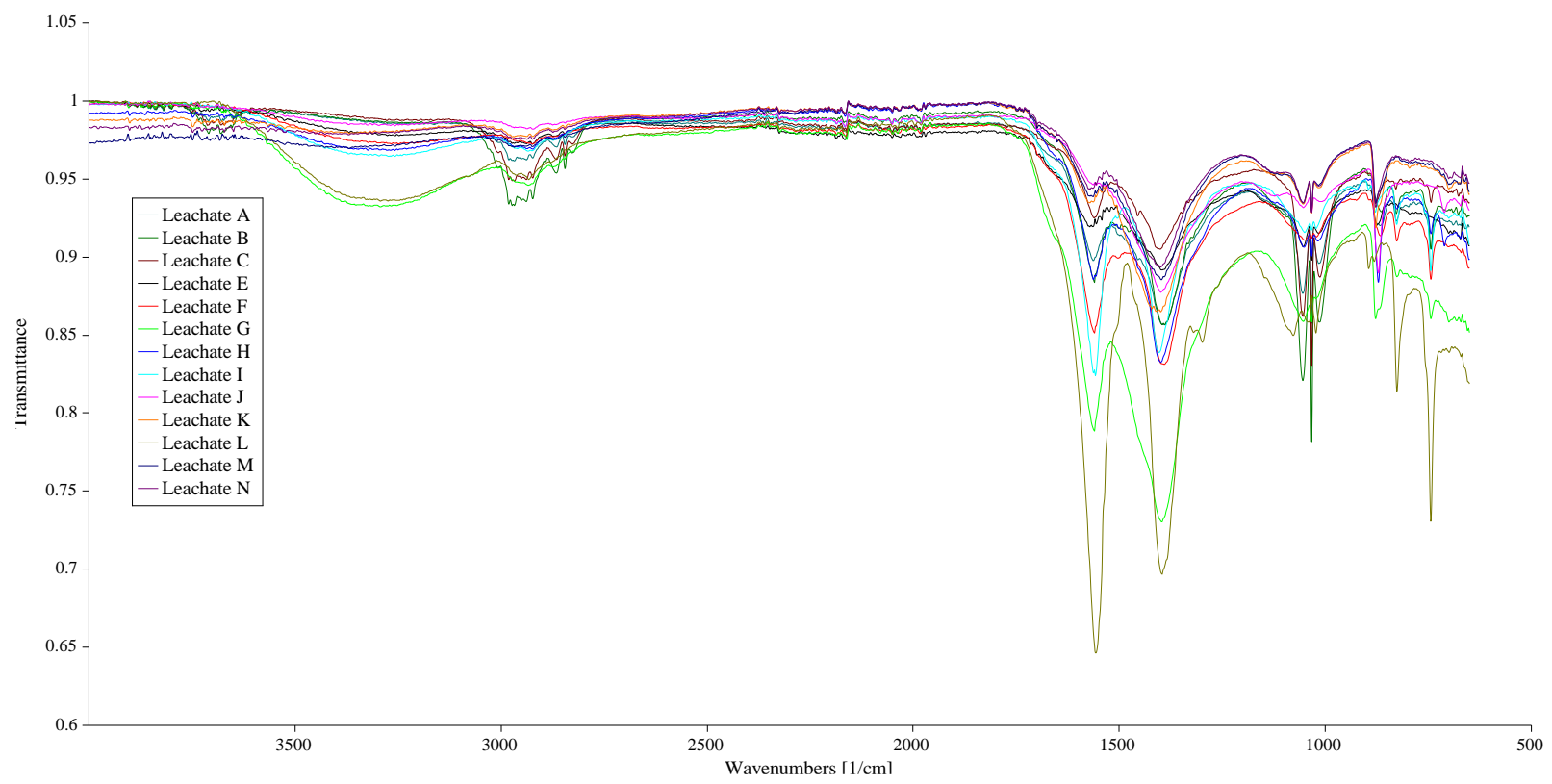

Figure G-1. FTIR Spectrum of Dried Leachate Samples 


\section{APPENDIX H}

ELSEVIER LICENSE TERMS AND CONDITIONS: APPLICATION OF LANDFILL TREATMENT APPROACHES FOR THE STABILIZATION OF MUNICIPAL SOLID WASTE 


\section{ELSEVIER LICENSE TERMS AND CONDITIONS}

Mar 30, 2016

This is an Agreement between Stephanie C Bolyard ("You") and Elsevier ("Elsevier"). It consists of your order details, the terms and conditions provided by Elsevier, and the payment terms and conditions

All payments must be made in full to CCC. For payment instructions, please see information listed at the bottom of this form.

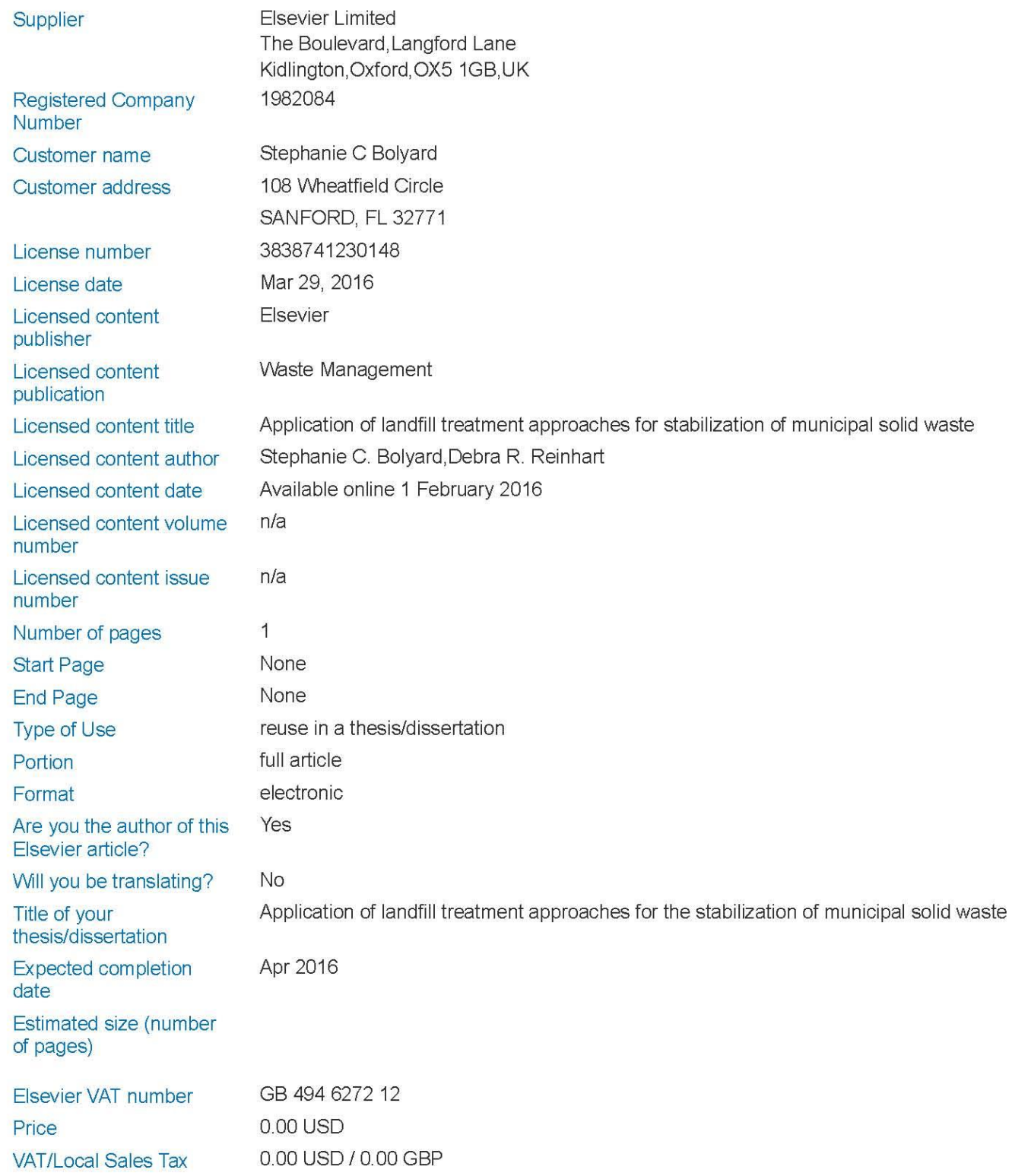


$3 / 30 / 2016$ Total 0.00 USD

Terms and Conditions
RightsLink - Your Account

\section{INTRODUCTION}

1. The publisher for this copyrighted material is Elsevier. By clicking "accept" in connection with completing this licensing transaction, you agree that the following terms and conditions apply to this transaction (along with the Billing and Payment terms and conditions established by Copyright Clearance Center, Inc. ("CCC"), at the time that you opened your Rightslink account and that are available at any time at $\underline{\mathrm{http}: / / \text { mvaccount.copvriaht.com) }}$.

\section{GENERAL TERMS}

2. Elsevier hereby grants you permission to reproduce the aforementioned material subject to the terms and conditions indicated.

3. Acknowledgement: If any part of the material to be used (for example, figures) has appeared in our publication with credit or acknowledgement to another source, permission must also be sought from that source. If such permission is not obtained then that material may not be included in your publication/copies. Suitable acknowledgement to the source must be made either as a footnote or in a reference list at the end of your publication, as follows:

"Reprinted from Publication title, Vol /edition number, Author(s), Title of article / title of chapter, Pages No., Copyright (Year), with permission from Elsevier [OR APPLICABLE SOCIETY COPYRIGHT OWNER]." Also Lancet special credit - "Reprinted from The Lancet, Vol. number, Author(s), Title of article, Pages No., Copyright (Year), with permission from Elsevier." 4. Reproduction of this material is confined to the purpose and/or media for which permission is hereby given.

5. Altering/Modifying Material: Not Permitted. However figures and illustrations may be altered/adapted minimally to serve your work. Any other abbreviations, additions, deletions and/or any other alterations shall be made only with prior written authorization of Elsevier Ltd. (Please contact Elsevier at permissions@elsevier.com)

6. If the permission fee for the requested use of our material is waived in this instance, please be advised that your future requests for Elsevier materials may attract a fee.

7. Reservation of Rights: Publisher reserves all rights not specifically granted in the combination of (i) the license details provided by you and accepted in the course of this licensing transaction, (ii) these terms and conditions and (iii) CCC's Billing and Payment terms and conditions.

8. License Contingent Upon Payment: While you may exercise the rights licensed immediately upon issuance of the license at the end of the licensing process for the transaction, provided that you have disclosed complete and accurate details of your proposed use, no license is finally effective unless and until full payment is received from you (either by publisher or by $\mathrm{CCC}$ ) as provided in CCC's Billing and Payment terms and conditions. If full payment is not received on a timely basis, then any license preliminarily granted shall be deemed automatically revoked and shall be void as if never granted. Further, in the event that you breach any of these terms and conditions or any of CCC's Billing and Payment terms and conditions, the license is automatically revoked and shall be void as if never granted. Use of materials as described in a revoked license, as well as any use of the materials beyond the scope of an unrevoked license, may constitute copyright infringement and publisher reserves the right to take any and all action to protect its copyright in the materials.

9. Warranties: Publisher makes no representations or warranties with respect to the licensed material.

10. Indemnity: You hereby indemnify and agree to hold harmless publisher and CCC, and their respective officers, directors, employees and agents, from and against any and all claims arising out of your use of the licensed material other than as specifically authorized pursuant to this license.

11. No Transfer of License: This license is personal to you and may not be sublicensed, assigned, or transferred by you to any other person without publisher's written permission.

12. No Amendment Except in Witing: This license may not be amended except in a writing signed by both parties (or, in the case of publisher, by CCC on publisher's behalf).

13. Objection to Contrary Terms: Publisher hereby objects to any terms contained in any purchase order, acknowledgment, check endorsement or other writing prepared by you, which terms are inconsistent with these terms and conditions or CCC's Billing and Payment terms and conditions. These terms and conditions, together with CCC's Billing and Payment terms and conditions (which are incorporated herein), comprise the entire agreement between you and publisher (and CCC) concerning this licensing transaction. In the event of any conflict between your obligations established by these terms and conditions and those established by CCCs Billing and Payment terms and conditions, these terms and conditions shall control. 14. Revocation: Elsevier or Copyright Clearance Center may deny the permissions described in this License at their sole discretion, for any reason or no reason, with a full refund payable to you. Notice of such denial will be made using the contact information provided by you. Failure to receive such notice will not alter or invalidate the denial. In no event will Elsevier or Copyright Clearance Center be responsible or liable for any costs, expenses or damage incurred by you as a result of a denial of your permission request, other than a refund of the amount(s) paid by you to Elsevier and/or Copyright Clearance Center for denied permissions.

\section{LIMITED LICENSE}

The following terms and conditions apply only to specific license types 
15. Translation: This permission is granted for non-exclusive world English rights only unless your license was granted for translation rights. If you licensed translation rights you may only translate this content into the languages you requested. A professional translator must perform all translations and reproduce the content word for word preserving the integrity of the article.

16. Posting licensed content on any Website: The following terms and conditions apply as follows: Licensing material from an Elsevier journal: All content posted to the web site must maintain the copyright information line on the bottom of each image; A hyper-text must be included to the Homepage of the journal from which you are licensing at http://www.sciencedirect.com/science/journal/xxxxx or the Elsevier homepage for books at http://www. elsevier.com; Central Storage: This license does not include permission for a scanned version of the material to be stored in a central repository such as that provided by Heron/XanEdu.

Licensing material from an Elsevier book: A hyper-text link must be included to the Elsevier homepage at http://www. elsevier.com. All content posted to the web site must maintain the copyright information line on the bottom of each image.

Posting licensed content on Electronic reserve: In addition to the above the following clauses are applicable: The web site must be password-protected and made available only to bona fide students registered on a relevant course. This permission is granted for 1 year only. You may obtain a new license for future website posting.

17. For journal authors: the following clauses are applicable in addition to the above:

\section{Preprints:}

A preprint is an author's own write-up of research results and analysis, it has not been peer-reviewed, nor has it had any other value added to it by a publisher (such as formatting, copyright, technical enhancement etc.).

Authors can share their preprints anywhere at any time. Preprints should not be added to or enhanced in any way in order to appear more like, or to substitute for, the final versions of articles however authors can update their preprints on arXiv or RePEc with their Accepted Author Manuscript (see below).

If accepted for publication, we encourage authors to link from the preprint to their formal publication via its DOI. Millions of researchers have access to the formal publications on ScienceDirect, and so links will help users to find, access, cite and use the best available version. Please note that Cell Press, The Lancet and some society-owned have different preprint policies. Information on these policies is available on the journal homepage.

Accepted Author Manuscripts: An accepted author manuscript is the manuscript of an article that has been accepted for publication and which typically includes author-incorporated changes suggested during submission, peer review and editorauthor communications.

Authors can share their accepted author manuscript:

- immediately

via their non-commercial person homepage or blog

byoupdating a preprint in arXiv or RePEc with the accepted manuscript

via their research institute or institutional repository for internal institutional uses or as part of an invitation-only research collaboration work-group

directly by providing copies to their students or to research collaborators for their personal use

for private scholarly sharing as part of an invitation-only work group on commercial sites with which Elsevier has an agreement

after the embargo period

via non-commercial hosting platforms such as their institutional repository

via commercial sites with which Elsevier has an agreement

In all cases accepted manuscripts should:

- link to the formal publication via its DOI

- bear a CC-BY-NC-ND license - this is easy to do

- $\quad$ if aggregated with other manuscripts, for example in a repository or other site, be shared in alignment with our hosting policy not be added to or enhanced in any way to appear more like, or to substitute for, the published journal article.

Published journal article (JPA): A published journal article (PJA) is the definitive final record of published research that appears or will appear in the journal and embodies all value-adding publishing activities including peer review co-ordination, copy-editing, formatting, (if relevant) pagination and online enrichment.

Policies for sharing publishing journal articles differ for subscription and gold open access articles: 
Subscription Articles: If you are an author, please share a link to your article rather than the full-text. Millions of researchers have access to the formal publications on ScienceDirect, and so links will help your users to find, access, cite, and use the best available version.

Theses and dissertations which contain embedded PJAs as part of the formal submission can be posted publicly by the awarding institution with DOI links back to the formal publications on ScienceDirect.

If you are affiliated with a library that subscribes to ScienceDirect you have additional private sharing rights for others' research accessed under that agreement. This includes use for classroom teaching and internal training at the institution (including use in course packs and courseware programs), and inclusion of the article for grant funding purposes.

Gold Open Access Articles: May be shared according to the author-selected end-user license and should contain a CrossMark logo, the end user license, and a DOI link to the formal publication on ScienceDirect.

Please refer to Elsevier's posting policy for further information.

18. For book authors the following clauses are applicable in addition to the above: Authors are permitted to place a brief summary of their work online only. You are not allowed to download and post the published electronic version of your chapter, nor may you scan the printed edition to create an electronic version. Posting to a repository: Authors are permitted to post a summary of their chapter only in their institution's repository.

19. Thesis/Dissertation: If your license is for use in a thesis/dissertation your thesis may be submitted to your institution in either print or electronic form. Should your thesis be published commercially, please reapply for permission. These requirements include permission for the Library and Archives of Canada to supply single copies, on demand, of the complete thesis and include permission for Proquest/UMI to supply single copies, on demand, of the complete thesis. Should your thesis be published commercially, please reapply for permission. Theses and dissertations which contain embedded PJAs as part of the formal submission can be posted publicly by the awarding institution with DOI links back to the formal publications on ScienceDirect.

\section{Elsevier Open Access Terms and Conditions}

You can publish open access with Elsevier in hundreds of open access journals or in nearly 2000 established subscription journals that support open access publishing. Permitted third party re-use of these open access articles is defined by the author's choice of Creative Commons user license. See our open access license policy for more information.

\section{Terms \& Conditions applicable to all Open Access articles published with Elsevier:}

Any reuse of the article must not represent the author as endorsing the adaptation of the article nor should the article be modified in such a way as to damage the author's honour or reputation. If any changes have been made, such changes must be clearly indicated.

The author(s) must be appropriately credited and we ask that you include the end user license and a DOI link to the formal publication on ScienceDirect.

If any part of the material to be used (for example, figures) has appeared in our publication with credit or acknowledgement to another source it is the responsibility of the user to ensure their reuse complies with the terms and conditions determined by the rights holder.

\section{Additional Terms \& Conditions applicable to each Creative Commons user license:}

CC BY: The CC-BY license allows users to copy, to create extracts, abstracts and new works from the Article, to alter and revise the Article and to make commercial use of the Article (including reuse and/or resale of the Article by commercial entities), provided the user gives appropriate credit (with a link to the formal publication through the relevant DOI), provides a link to the license, indicates if changes were made and the licensor is not represented as endorsing the use made of the work. The full details of the license are available at http://creativecommons. org/licenses/by/4.0.

CC BY NC SA: The CC BY-NC-SA license allows users to copy, to create extracts, abstracts and new works from the Article, to alter and revise the Article, provided this is not done for commercial purposes, and that the user gives appropriate credit (with a link to the formal publication through the relevant DOI), provides a link to the license, indicates if changes were made and the licensor is not represented as endorsing the use made of the work. Further, any new works must be made available on the same conditions. The full details of the license are available at $\underline{h t t p}: / /$ creativecommons.ora/licenses/bv-nc-sa/4.0 CC BY NC ND: The CC BY-NC-ND license allows users to copy and distribute the Article, provided this is not done for commercial purposes and further does not permit distribution of the Article if it is changed or edited in any way, and provided the user gives appropriate credit (with a link to the formal publication through the relevant DOI), provides a link to the license, and that the licensor is not represented as endorsing the use made of the work. The full details of the license are available at http://creativecommons.org/licenses/bv-nc-nd/4.O. Any commercial reuse of Open Access articles published with a CC BY NC SA or CC BY NC ND license requires permission from Elsevier and will be subject to a fee.

Commercial reuse includes:

Associating advertising with the full text of the Article

Charging fees for document delivery or access 
- Article aggregation

- Systematic distribution via e-mail lists or share buttons

Posting or linking by commercial companies for use by customers of those companies.

\section{Other Conditions:}

v1.8

Questions? customercare@copyright.com or +1-855-239-3415 (toll free in the US) or +1-978-646-2777. 